UNIVERSIDADE DE SÃO PAULO

FFCLRP - DEPARTAMENTO DE PSICOLOGIA

PROGRAMA DE PÓS-GRADUAÇÃO EM PSICOLOGIA

CARMEN SILVIA PORTO BRUNIALTI JUSTO

Psicologia, Marketing e Experiência Elementar: implicações para o desenvolvimento do conceito de consumidor.

Ribeirão Preto - SP

2014 

CARMEN SILVIA PORTO BRUNIALTI JUSTO

Psicologia, Marketing e Experiência Elementar: implicações para o desenvolvimento do conceito de consumidor.

Dissertação apresentada ao Departamento de Psicologia da Faculdade de Filosofia, Ciências e Letras de Ribeirão Preto da USP, como requisito para obtenção do título de mestre em Psicologia.

Área de concentração: Subjetivação: Processos culturais, linguagem e história.

Orientadora: Professora Titular Marina Massimi

RIBEIRÃO PRETO - SP 
Autorizo a reprodução e divulgação total ou parcial deste trabalho, por qualquer meio convencional ou eletrônico, para fins de estudo e pesquisa, desde que citada a fonte.

FICHA CATALOGRÁFICA

Justo, Carmen Silvia Porto Brunialti.

Psicologia, Marketing e Experiência Elementar: implicações para o desenvolvimento do conceito de consumidor. Ribeirão Preto, 2014. 167 p.:il; 30cm

Dissertação de Mestrado, apresentada à Faculdade de Filosofia, Ciências e Letras de Ribeirão Preto/USP. Área de concentração: Psicologia, Processos Culturais e Subjetivação.

Orientadora: Massimi, Marina.

1. História da Psicologia. 2. Desenvolvimento do Conceito de Consumidor. 3. Experiência elementar e psicologia. 4. História do Marketing. 
Nome: Justo, Carmen Silvia Porto Brunialti.

Título: Psicologia, Marketing e Experiência Elementar: implicações para o desenvolvimento do conceito de consumidor.

Dissertação apresentada ao Departamento de Psicologia da Faculdade de Filosofia, Ciências e Letras de Ribeirão Preto da USP, como requisito para obtenção do título de mestre em Psicologia.

Área de concentração: Subjetivação: Processos culturais, linguagem e história.

Aprovado em:

Banca examinadora

Prof. Dr. :

Instituição: Assinatura:

Prof. Dr.

Instituição:

Assinatura:

Prof. Dr.:

Instituição: Assinatura: 

Ao meu marido Antonio Cesar, e minhas filhas Beatrize Gabriela, pelo apoio, paciência e acima de tudo pelo amor incondicional.

A todos os profissionais e alunos de Marketing e Comunicação que, assim como eu, buscam um sentido ético e humano nas atividades que envolvem a prática e a docência dessa profissão. 



\section{AGRADECIMENTOS}

Obrigada Deus Pai e Criador, por tornar tudo isso possível!

Ao meu esposo e companheiro, Antonio Cesar por me incentivar sempre a continuar meus estudos. Sem o seu apoio e participação nos cuidados com nossas filhas, eu jamais conseguiria finalizar mais essa etapa. Meu amor eterno.

As minhas filhas Beatriz e Gabriela, que durante esse período, estiveram do meu lado e entenderam a importância dessa etapa na minha vida. Esse trabalho só foi possível porque vocês também me motivaram com sua presença amiga e companheira. Vocês são a minha inspiração para enfrentar tantos desafios.

Aos meus pais, Vladmir e Maria Amélia que durante muitos anos se sacrificaram por meus estudos e que agora, de uma forma muito especial, estiveram do meu lado, mesmo quando tivemos que nos ausentar das reuniões familiares. Meu profundo amor por vocês.

As minhas irmãs Viviane e Gisele, que me incentivaram sempre a continuar. Ao meu cunhado Anderson e, meus sobrinhos Matheus e Nicolas, por participarem, mesmo distantes dessa etapa.

À minha segunda família, Lucia, Geraldo, Almir, Alessandro, Karen, Arthur e Yasmim, pelas orações e incentivos durante o mestrado.

À Profa. Dra. Marina Massimi, minha orientadora, por acreditar no meu trabalho. Sem a sua ajuda, incentivo e amizade eu jamais conseguiria. Meu respeito e admiração por seu trabalho como educadora, psicóloga e pesquisadora. Serei eternamente grata por essa oportunidade.

Ao Prof. Dr. Miguel Mahfoud, da Universidade Federal de Minas Gerais, por me apresentar os estudos sobre Experiência elementar, e pela presença amiga e acolhedora, durante as etapas do meu projeto de mestrado e, durante as etapas iniciais do meu trabalho. Minha admiração e meu respeito por seu trabalho como educador e pesquisador.

À Profa. Dra. Carmen Lucia Cardoso, da Faculdade de Psicologia - USP, pelos conselhos e dicas nas etapas iniciais desse percurso.

As professoras avaliadoras: Dra. Carla Guanaes - USP e Dra. Raquel de Assis UFMG, pelas orientações técnicas na qualificação desse trabalho que foram fundamentais para sua conclusão. 
À amiga Eneida Nogueira pela amizade, e exemplos de vida e determinação. Obrigada pelas dicas e presença tão confiante, mesmo enfrentando tantos momentos difíceis.

À Carolina de Resende Damas Cardoso, por me ensinar os caminhos da Psicologia. Por me ajudar a enfrentar os artigos, os conceitos, os textos e a minha pesquisa. Você foi parte fundamental desse trabalho Carol e te agradeço de coração!

Aos amigos Roberta Vasconcelos e Yuri Elias Gaspar, da UFMG, pela amizade e pelas aulas do curso de Extensão em Experiência elementar. Obrigada por me acolherem como pesquisadora, em eventos e congressos, e por me ajudarem a encontrar o meu caminho nesse tema, que foi fundamental para o desenvolvimento de minha pesquisa.

Aos amigos Sandro Gontijo, Ir. Adair Sberga e Milena Callegari Cosentino. Em diferentes momentos, vocês foram presenças marcantes nesse percurso. Obrigada pelas dicas e ensinamentos!

Aos amigos do grupo de estudos "História e Memória": Gabriel, Rodrigo Miranda, Lidiane, Lívia, Nayara, Clara, Suzana, Alekssey e Frei Sérgio, pelas dicas nos estudos, pela amizade e carinho. Aos amigos desse grupo que já se formaram, mas que com sua amizade e atenção, também me ajudaram muito: Rodrigo Borgheti, Gabriela, José Maurício, Maira e Padre Marcos Candido. Aos jovens pesquisadores do grupo: João, Caio Cesar e Ana Luiza, meu desejo é que vocês continuem sempre nesse caminho de estudos e conhecimento.

Aos amigos professores do Centro Universitário Moura Lacerda: Raquel Lovatti, Fernando Mello, Célia Regina, Romilson Madeira, Silas Nogueira, Osvaldo Tadeu Lopes, Liani Moraes e, alunos do curso de Publicidade e Propaganda. Obrigada pelo incentivo, amizade e carinho.

Aos meus amigos do Grupo Comunhão e Libertação: Matilde, Cristina Langer, Estela, Carmen Rita, Márcia e Erico, Sueli, Alexandre e Valquíria. Suas orações e incentivos nas etapas iniciais foram fundamentais.

Aos amigos e familiares de outras épocas que me influenciaram e me apoiaram de diferentes formas. Em especial Ana Virginia Francisco, Jefferson e Maria Guiomar, Daniela e Antonio José, Josimar Baggio e Giovana Ottoni pelo incentivo e amizade. 
Todas as experiências da minha humanidade e da minha personalidade, passam pelo crivo de uma "experiência original", primordial, que constitui o meu rosto ao confrontar-me com tudo. Aquilo que cada homem tem o direito e o dever de aprender é a possibilidade e o hábito de comparar cada proposta com esta sua "experiência elementar".

(Luigi Giussani) 



\section{RESUMO}

Justo, C.S.P.B. (2014). Psicologia, Marketing e Experiência Elementar: implicações para o desenvolvimento do conceito de consumidor. Dissertação (Mestrado). Departamento de Psicologia. Faculdade de Filosofia, Ciências e Letras de Ribeirão Preto, Universidade de São Paulo, Ribeirão Preto, SP.

O objetivo principal dessa pesquisa é compreender como teorias da psicologia contribuíram para a formação do conceito de consumidor na atualidade, em especial a proposta da Experiência elementar que se fundamenta em uma concepção de pessoa humana. Trata-se de uma pesquisa de investigação histórica e está inserida no âmbito da história do Marketing, da Psicologia Científica e da Psicologia do Consumidor, no período que compreende o final do século XIX e o século XX. No início do século XX, o Marketing como ciência se estruturou e ganhou espaço no meio acadêmico como disciplina independente da economia, o que possibilitou o surgimento dessa área de estudos e atividade. As condições econômicas e sociais dos Estados Unidos na virada do século XX propiciaram a aproximação das áreas do Marketing e da Psicologia principalmente no ambiente acadêmico e nos laboratórios de pesquisa experimental, através de estudos sobre comportamento, memória, motivação e aprendizagem. A criação da Divisão 23 (Divisão de Psicologia do Consumidor) na APA American Psychology Association, na década de 1960, legitimou os estudos dessa área específica, que derivaram na área de Marketing e nos estudos sobre o Comportamento do Consumidor. O desenvolvimento do Marketing Contemporâneo, a partir do final do século $\mathrm{XX}$, carrega as influências da interface entre essas áreas e sugere a possibilidade de se relacionar o conceito de consumidor mais voltado ao sentido de pessoa, mas sem a fundamentação antropológica e filosófica condizente. Na busca por uma fundamentação que apoiasse essas tendências e ampliasse a discussão sobre o conceito de consumidor no mundo contemporâneo, nos aproximamos da abordagem da Experiência elementar de Luigi Giussani (2009). A escolha dessa abordagem para discussão do conceito de consumidor apoia-se no fato de propor análises sobre a pessoa, cuja profundidade pode proporcionar uma fundamentação mais rigorosa acerca do tema. A conclusão remete à ideia de que no século XXI existe uma possibilidade de se considerar o consumidor como "pessoa", e que a abordagem da Experiência elementar pode ser pertinente para discutir essa aproximação a partir das novas tendências do Marketing, que buscam uma perspectiva mais humana para essa atividade.

Palavras-chave: 1. História da Psicologia. 2. Desenvolvimento do Conceito de Consumidor. 3. Experiência elementar e psicologia. 4. História do Marketing. 



\begin{abstract}
Justo, C.S.P.B. (2014). Psychology, Marketing and Elementary Experience: implications for the consumer concept. Dissertação (Mestrado). Departamento de Psicologia. Faculdade de Filosofia, Ciências e Letras de Ribeirão Preto, Universidade de São Paulo, Ribeirão Preto, SP.
\end{abstract}

The main objective of this research is to understand how Psychology theories have contributed to the formation of current consumer concept, especially regarding the proposal of Elementary experience, which is founded on a personal conception of the human being. This historical investigation research is inserted within the scope of the history of Marketing, of Scientific Psychology, as well as the Consumer Psychology, in the period encompassing the end of the $19^{\text {th }}$ century and the $20^{\text {th }}$ century. In the beginning of the $20^{\text {th }}$ century, Marketing as a science was structured and gained space in the academic field as an independent discipline, apart from Economics, thus enabling the appearance of this study area and activity. The social and economic conditions of the United States at the turn of the $20^{\text {th }}$ century made the approximation of the areas of Marketing and Psychology possible, mainly in the academic environment and in the laboratories of experimental research, through behavior, memory, motivational and learning researches. The creation of Division 23 (Consumer Psychology Division) in the APA - American Psychology Association - in the sixties has legitimated the studies on this specific area, which originated the area of Marketing and consumer's behavioral studies. The development of modern Marketing, as of the end of the $20^{\text {th }}$ century, carries on the interface influences between those two areas, suggesting the possibility of relating the concept of consumer to the concept of human being, in a more personal sense, but without the proper anthropological and philosophical grounding. The search for a founding basis, which could support those tendencies by enlarging the discussions regarding the consumer concept in today's world, has led us to approach the proposal of the Elementary experience, by Luigi Giussani (2009). The choice of this approach for discussing the consumer concept lies on the fact that establishes the proposition of analyses to be made about the individual, whose depth may supply a more rigorous foundation for this theme. The conclusion emerges from the idea that there is a possibility of considering a consumer as an individual in the $21^{\text {st }}$ century, and that the approach based on these new Marketing tendencies tries to make possible a more humane perspective for this activity.

Key words: 1. History of Psychology. 2. Development of the consumer concept. 3. Elementary experience and Psychology. 4. History of Marketing. 



\section{LISTA DE FIGURAS}

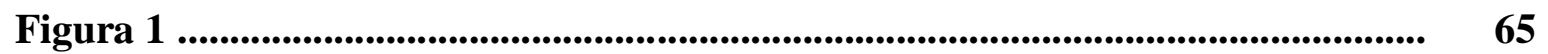

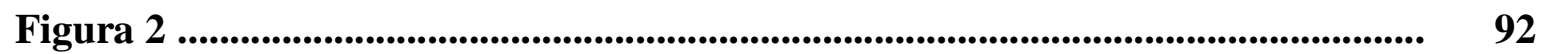

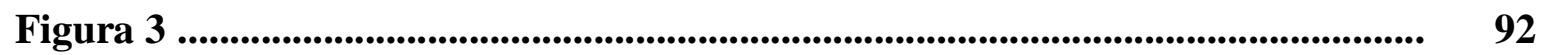

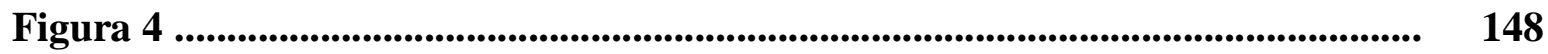

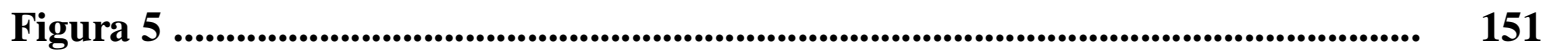

Figura 6 ..................................................................................................................................... 153

Figura 7 ............................................................................................................................................. 155 



\section{LISTA DE TABELAS}

Tabela 1

Tabela 2

61

Tabela 3

Tabela 4 ..

Tabela 5

Tabela 6

Tabela 7

Tabela 8

Tabela 9

Tabela 10 



\section{Sumário}

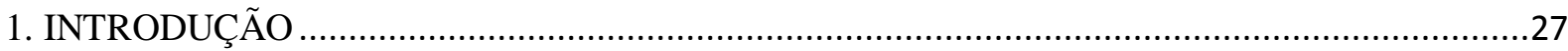

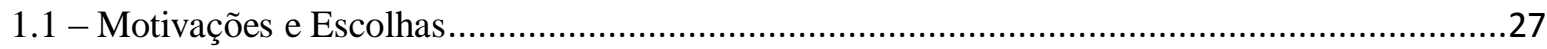

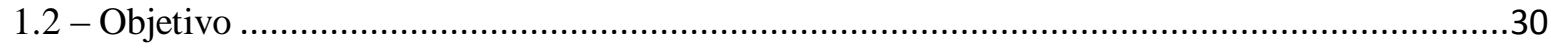

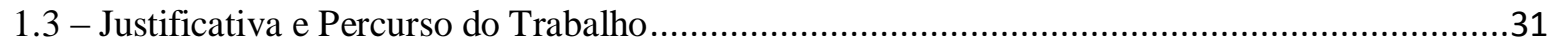

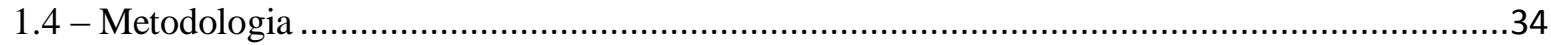

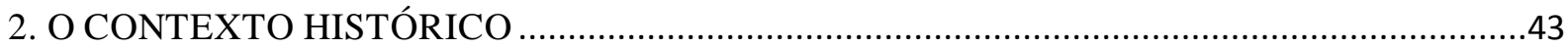

2.1 - O contexto histórico do surgimento do Marketing e da Psicologia do Consumidor.

2.2 - O conceito de consumidor: cronologia histórica a partir das escolas do pensamento em marketing e a contribuição dos pioneiros da psicologia aplicada a partir do início do século XX nos

Estados Unidos até o início do século XXI.

2.2.1 - Período anterior a 1900 - Escolas Clássica ou Neoclássica - 1900 a 1910 - Período da

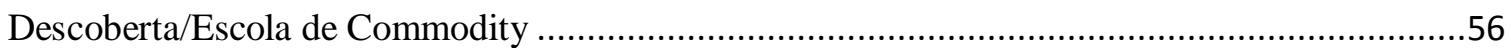

2.2.2 - 1910 a 1920 - Conceituação/Escola Funcional .............................................................56

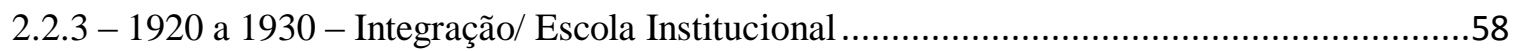

2.2.4 - 1930 a 1940 - Desenvolvimento/ Escola Funcionalista....................................................58

2.2.5 - 1940 a 1950 - Reavaliação/ Escola Administrativa........................................................60

2.2.6 - 1950 a 1960 - Reconceituação/ Escola do Comportamento do consumidor......................61

2.2.7 - 1960 a 1970 - Diferenciação/ Escola Dinâmica Organizacional........................................62

2.2.8 - 1970 a 1980 - Socialização/Escola Ativista/ 1980 - Marketing de Relacionamento - 1990

- Cybermarketing/ 1990 - 2000 - Marketing Experiencial......................................................66

3 - PSICOLOGIA, MARKETING E O CONCEITO DE CONSUMIDOR NUMA PERSPECTIVA

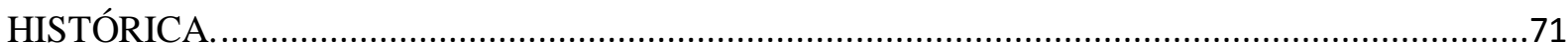

3.1 - O desenvolvimento da psicologia científica e da psicologia do consumidor nos Estados

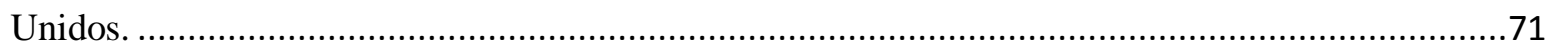

3.2 - A contribuição dos pioneiros da psicologia do consumidor nos Estados Unidos. ...................74

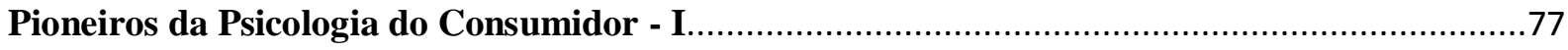

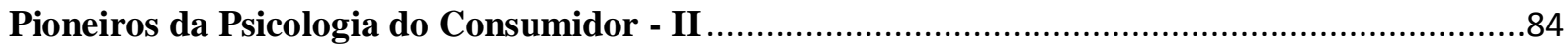

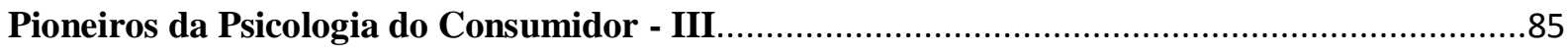

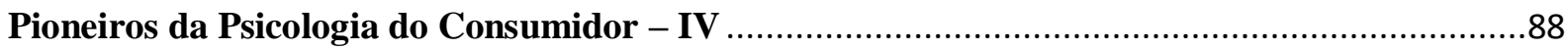

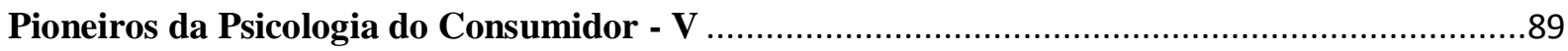

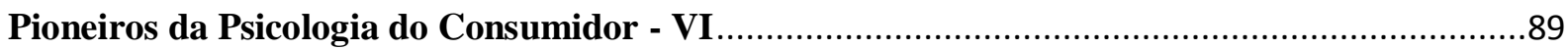

Figura 2 - Linha do tempo - Pioneiros da psicologia do consumidor (1900-1940) .............................92

Figura 3 - Linha do tempo - Pioneiros da psicologia do consumidor $(1940$-1950) ............................92

3.3 - O conceito de consumidor e as novas tendências do Marketing. ……...................................93

4 - A PESSOA, A EXPERIÊNCIA E A EXPERIÊNCIA ELEMENTAR ........................................101 
4.1 - O conceito de pessoa na Idade Moderna e as implicações para o marketing contemporâneo. 101

4.2 - O conceito de experiência - breve contexto histórico

4.3 - O conceito de experiência para a área do Marketing e sua relação com o conceito de experiência na psicologia, e o conceito de Experiência elementar.

4.4 - Biografia de Luigi Giovanni Giussani - autor do conceito de Experiência Elementar.

4.5 - O conceito de Experiência elementar: reflexões sobre a interface com o conceito de consumidor a partir das premissas (realismo, razoabilidade e moralidade sobre a dinâmica do conhecimento).

5 - EXPERIÊNCIA ELEMENTAR, PSICOLOGIA E MARKETING: COMO ESSES TEMAS SE RELACIONAM COM O CONCEITO DE CONSUMIDOR NO MUNDO CONTEMPORÂNEO. .141

5.1.- O "eu-em-ação" 144

5.2 - O compromisso com a vida 146

5.3 - Aspectos do Compromisso (a tradição) 149

5.4 - Aspectos do Compromisso (o presente) 152

5.5 - Dupla realidade e redução materialista 154

6 - CONSIDERAÇÕES FINAIS 157

7 - REFERÊNCIAS 161

8 - ANEXO - RELAÇÃO DE OBRAS DE LUIGI GIUSSANI 167 


\section{PSICOLOGIA, MARKETING E EXPERIÊNCIA ELEMENTAR: IMPLICAÇÕES PARA A EVOLUÇÃO DO CONCEITO DE CONSUMIDOR.}

\section{INTRODUÇÃO}

\section{1 - Motivações e Escolhas}

O interesse em estudar história da Psicologia e suas interfaces com a área de Marketing surgiu quando me matriculei como aluna especial, na disciplina de “História da Psicologia: objetos, métodos e problemas”, ministrada pela Profa. Dra. Marina Massimi, no primeiro semestre de 2008, no curso de pós-graduação em Psicologia da Faculdade de Filosofia, Ciências e Letras da Universidade de São Paulo. O conteúdo da disciplina referia-se ao percurso histórico da área da Psicologia e abrangia duas partes fundamentais: história dos Saberes Psicológicos e história da Psicologia Científica.

A disciplina oferecia, além da delimitação desses campos distintos, a relação entre os temas da psicologia, cultura e história de forma interdisciplinar o que abria a possibilidade de diálogos com diferentes áreas das ciências humanas e sociais aplicadas. A relação entre esses temas foi apresentado pela professora como parte do desenvolvimento dos saberes psicológicos nas culturas humanas numa perspectiva histórica. Foi nesse contexto, através das leituras e discussões, que pude reconhecer a importância dos estudos psicológicos e suas relações com as diferentes áreas que tem como objeto de estudos as pessoas e sua interação com o ambiente social, político, econômico e cultural.

Ao final da disciplina apresentei um trabalho com o título: "Psicologia, História, Propaganda e Consumo: o que eles tem em comum”, com o objetivo de analisar os temas propostos pela disciplina, e como a história da psicologia e dos saberes psicológicos tinha contribuído para o desenvolvimento das áreas do marketing e da propaganda. As observações e análises da professora com relação a esse trabalho, indicando caminhos para o meu aprofundamento na área da psicologia, é que me motivaram a continuar os estudos na história da psicologia. Passei, então, a frequentar o grupo de pesquisa: "Estudos em psicologia e ciências humanas: história e memória".

Sou graduada em Comunicação Social - com habilitação em Publicidade e Propaganda e Letras - com habilitação em português e inglês e, pós-graduada em Marketing. 
Atuo na área de Marketing há mais de vinte anos. Há aproximadamente dez anos, tenho me dedicado à carreira acadêmica como docente em cursos superiores de Publicidade, Propaganda e Marketing. Nessas áreas específicas, as questões sobre o consumo e o comportamento do consumidor são consideradas um dos objetos centrais das estratégias mercadológicas que tem como objetivo principal a comunicação e a venda de diferentes produtos e serviços. As definições sobre o conceito de consumidor - "aquele que consome", estão sempre atreladas às estratégias desenvolvidas e criadas para abordá-lo no momento da compra. Assim, a relação entre as teorias psicológicas e os estudos sobre mercado, mídia, consumo e consumidor proporcionam ferramentas importantes no entendimento e interpretação das necessidades e desejos dos consumidores.

Desde que me aproximei da universidade, passando a atuar como educadora, comecei a me preocupar com a formação crítica, ética e multidisciplinar do estudante de comunicação e marketing, diante da influência que a área da comunicação exerce nos diferentes contextos sociais, econômicos e culturais.

$\mathrm{Na}$ formação do profissional de marketing e comunicação social, por exemplo, existem diferenças nos projetos pedagógicos das escolas, ocasionando variações no tipo de formação oferecida. Alguns cursos contemplam em sua grade as disciplinas de formação mais técnicas (aquelas que fazem parte da formação específica do profissional de marketing e comunicação) o que diminui, em alguns casos, a carga horária das disciplinas de formação humanista, entre elas: a sociologia, a filosofia e a ética, podendo reduzir, também em algumas situações, o desenvolvimento da capacidade crítica desse profissional. As orientações para os conteúdos programáticos desses cursos são regidos pelos parâmetros curriculares nacionais dos cursos de Comunicação Social ${ }^{1}$. As normas curriculares datam do ano de 2001 e, portanto, há doze anos não sofrem mudanças significativas em sua forma e estrutura.

Já os cursos específicos de marketing de graduação tecnológica possuem uma grade curricular mais atualizada, mas priorizam a formação mais estratégica e gerencial e não se aprofundam nas disciplinas de formação humana.

Diante de tantos desafios enfrentados pelos profissionais dessas áreas, parece que as questões referentes aos temas relativos consumo, consumismo, motivação, necessidades e desejos, são desconsiderados do processo de formação dos publicitários e profissionais de marketing, o que acaba colaborando para que, sob as pressões do mercado, esses profissionais não se posicionem de forma adequada frente a esses temas. Outras áreas, como a Pedagogia e

\footnotetext{
${ }^{1}$ Parecer CNE/CES no. 492, de 3 de abril de 2001. Retirado do World Wide Web: http://portal.mec.gov.br/cne/arquivos/pdf/CES0492.pdf acessado em 5 de abril de 2014.
} 
a Psicologia, se posicionam de forma mais crítica diante dessas discussões e, em algumas situações, exerce-se a crítica negativa em relação à atuação profissional do publicitário e do profissional de marketing.

O contato com a área da história da Psicologia me motivou a pesquisar com mais profundidade teorias psicológicas que se aproximam da área de Marketing e contribuem para as definições e interpretações do conceito de consumidor na atualidade, tendo em vista a possibilidade de colaborar com a formação acadêmica e profissional dos graduandos em publicidade, propaganda e marketing. Surgiu, então, a ideia de pesquisar os modos pelos quais as contribuições de ambas as áreas, Marketing e Psicologia, foram fundamentais para o desenvolvimento do conceito de consumidor na perspectiva histórica.

A vontade de estudar com mais profundidade a história da Psicologia e sua relação com a história do Marketing surgiu a partir desse encontro com o grupo de pesquisa e com a linha de trabalho da referida professora, que sinalizou uma profunda simpatia por minhas pesquisas e pelas motivações que me fizeram escolher essa área específica de estudos.

No ano de 2010, participei do curso de Extensão "Introdução à Experiência elementar", ministrado pelo Prof. Dr. Miguel Mahfoud, da Universidade Federal de Minas Gerais. O professor Miguel, da área da Psicologia Social, apresentou o tema da experiência elementar proposto pelo educador e filósofo Luigi Giussani (2009), na obra “O senso religioso", que analisa com profundidade a trajetória da realização humana, procurando, através de suas experiências com a realidade, compreender o ser humano de uma forma mais completa. Essa abordagem tem sido estudada desde 2005 pelo Departamento de Psicologia da Faculdade de Filosofia e Ciências Humanas da Universidade Federal de Minas Gerais, com os títulos de: Experiência elementar em Psicologia I e II, Estágio Supervisionado II: Plantão Psicológico e Experiência elementar, chefiados pelo Prof. Dr. Miguel Mahfoud ${ }^{2}$. Entre 2009 e 2012, o "Grupo Experiência elementar em Psicologia: estudo, pesquisa e intervenção" ministrou diversos cursos de atualização sobre o tema nas cidades de São Paulo, Salvador, Belo Horizonte e Ribeirão Preto.

Ao abordar e relacionar esse tema com a área de Marketing e, mais especificamente, com o conceito de consumidor surgiu, no trabalho final desse curso, a possibilidade de

\footnotetext{
${ }^{2}$ Miguel Mahfoud é professor de Psicologia na Universidade Federal de Minas Gerais (UFMG), atuando na graduação e pós-graduação (mestrado e doutorado). É doutor em Psicologia Social pelo Instituto de Psicologia da Universidade de São Paulo. Realizou estudos de pós-doutorado na Pontifícia Universidade Lateranense de Roma, Itália. Sua linha de pesquisa é principalmente Cultura e Subjetividade, desenvolvendo temas ligados à fenomenologia, cultura popular e experiência religiosa. É editor da revista "Memorandum: memória e história em psicologia" e coordenador do Laboratório de Análise de Processos em Subjetividade (LAPS UFMG). Nos últimos anos, vem desenvolvendo o conceito de experiência elementar em suas implicações para a Psicologia (Mahfoud, 2012).
} 
ampliação desses estudos sobre o consumidor na perspectiva da "pessoa presente no consumidor". As novas tendências do Marketing contemporâneo sugerem mudanças nas abordagens estratégicas, considerando que o consumidor quer se relacionar com as marcas e produtos de uma forma mais transparente. As empresas, diante dessa nova realidade, estão repensando suas estratégias e seu papel social, econômico e ético.

Passei, então, a pesquisar, além do percurso histórico de aproximação entre as áreas de Marketing e Psicologia, a abordagem da Experiência elementar para discutir o conceito de consumidor no mundo contemporâneo.

A aproximação com a abordagem da experiência elementar só foi possível porque, na área de Marketing, alguns autores contemporâneos estudiosos do comportamento do consumidor, tem usado o termo "pessoa" para se referir àqueles que consomem os diferentes produtos e serviços. Ao analisar diversas estratégias mercadológicas e campanhas publicitárias, conseguimos identificar uma tentativa da área de Marketing de abordar o consumidor como uma pessoa "inserida nas relações de consumo", mas sem o aprofundamento filosófico e antropológico proposto pela experiência elementar. Foi a partir desse encontro e dessa possibilidade de aproximação entre as áreas que surgiu o meu projeto de mestrado.

Após a apresentação do trabalho "Experiência elementar, núcleo da pessoa e as suas implicações psicológicas no Marketing", na Sessão Coordenada - "Experiência Elementar em Psicologia", proposto pelo grupo de pesquisa do Prof. Miguel Mahfoud na reunião anual da SBP - Sociedade Brasileira de Psicologia, no ano de 2010, pude comprovar que esse trabalho repercutiu muito bem junto ao público presente e, parti, assim, para a formatação final desse projeto de dissertação de mestrado. No mês de agosto de 2011, ingressei oficialmente no programa de pós-graduação da Faculdade de Psicologia da USP de Ribeirão Preto.

\section{2 - Objetivo}

Compreender como teorias da psicologia contribuíram para a formação do conceito de consumidor na atualidade, em especial a proposta da Experiência elementar, que se fundamenta em uma concepção de pessoa humana. 


\section{3 - Justificativa e Percurso do Trabalho}

Os temas consumo e consumismo, motivação, necessidades e desejos são muito discutidos atualmente, principalmente nesse momento histórico em que a população mundial vivencia uma crise econômica que afeta diferentes povos em várias partes do mundo. Abaladas economicamente, algumas pessoas estão repensando a real necessidade de se consumir diferentes produtos e serviços, atribuindo o grande déficit financeiro das nações a diversas razões, mas também ao consumo de itens considerados supérfluos pelos consumidores comuns e pelo Estado. Nesse contexto, as pessoas são atraídas pelas necessidades de consumo, motivadas não só pelos apelos da mídia, mas por outras necessidades que diferem segundo as expectativas, as culturas e as condições psicológicas de cada um.

Entender como o Marketing $^{3}$, influencia, por meio de diferentes ações, o comportamento dos consumidores em suas relações de consumo, tem sido um grande desafio para os profissionais da área e educadores. Nos últimos anos, as atividades de marketing, erroneamente classificadas como ações de publicidade e propaganda, ou popularmente chamadas de ações na mídia, tornaram-se as grandes vilãs e agentes causadoras dos desvios comportamentais de diferentes grupos sociais. Para pedagogos, psicólogos, pais e autoridades diversas, as causas principais para os excessos de consumo, ou por decisões de compra de determinados produtos e serviços, são responsabilidade única e exclusiva das ações da mídia, principalmente a televisão. Segundo diferentes opiniões, esse veículo de comunicação invade os lares e manipula o pensamento e as ideias das crianças, jovens e adultos, descarregando uma imensa quantidade de informações, muitas vezes desnecessárias para sua formação humana, de modo a estimular o consumo.

O Marketing, em sua essência, deveria partir da análise do consumidor, ou mais especificamente, de grupos de consumidores no sentido de criar diferentes ações para que os produtos e serviços pudessem ser vendidos e consumidos. Entretanto, a realidade do mercado é que determina a atividade de marketing, criando certos "padrões de consumo" que podem desrespeitar, em algumas situações, o consumidor como ser humano. Como exemplo, no caso do consumidor infantil ${ }^{4}$, isso é mais evidente pelo fato deste, por estar em processo de

\footnotetext{
${ }^{3}$ Segundo Kotler (2000, p. 30) o conceito de Marketing é "o processo de planejar e executar a concepção, a determinação de preço (pricing), a promoção e a distribuição de ideias, bens e serviços para criar negociações que satisfaçam metas individuais e organizacionais".

${ }^{4}$ Entende-se como público infantil, para as atividades relacionadas ao marketing, crianças de 3 a 11 anos e 11 meses. Critério Brasil de classificação socioeconômica.
} 
desenvolvimento, não ter condições de firmar um posicionamento sobre suas decisões de consumo, e por não ter idade suficiente para fazer suas próprias escolhas.

$\mathrm{Na}$ literatura acadêmica da área de Marketing, o conceito de consumidor apresenta-se como "aquele que consome", ou "aquele que compra produtos e serviços para seu consumo". Ao estudar o comportamento dos consumidores, o profissional de marketing busca compreender as suas reações quanto ao consumo de produtos e serviços, propondo diferentes abordagens para incentivar a compra, através de estratégias mercadológicas. Nos últimos anos, as novas tendências na área de Marketing tem sugerido o termo "pessoas" para designar grupos de consumidores. Num estudo sobre as definições da área do comportamento do consumidor, Rodrigues (2013, p. 1451) apontou algumas definições:

[...] Mowen \& Minor (2003) definem esse campo como o estudo das unidades compradoras e dos processos de troca envolvidos na aquisição, no consumo e na disposição das mercadorias, serviços, experiências e ideias. Para Blackwell, Miniard \& Engel (2005) são as atividades de que as pessoas se ocupam quando obtêm, consomem e dispõem de produtos e serviços. Samara \& Morsch (2005) definem como o estudo que tem como objeto conhecer profundamente o comportamento das pessoas e suas necessidades, seus desejos e suas motivações, procurando entender o processo de como, quando e por que elas compram [...].

Por se tratar de uma área multidisciplinar, o Marketing, desde seu surgimento a partir da revolução industrial e do avanço da economia nos Estados Unidos, recebeu contribuições significativas das áreas da Sociologia, da Economia, da História e da Psicologia. Essa última em especial contribuiu de forma significativa, e psicólogos adeptos de diferentes teorias psicológicas se aproximaram da área com o objetivo de aplicar seus conhecimentos de psicologia nos estudos sobre memória, reforço, análise do comportamento e motivações. Nesse percurso, as investigações sobre o comportamento do consumidor, que até a década de 1950 não eram reconhecidos como área específica de pesquisa e de trabalho pela APA American Psychology Association - passaram a ganhar reconhecimento a partir da década de 1960, com o surgimento da Divisão 23 (Divisão de Psicologia do Consumidor), legitimando a área como sendo de pesquisa em comportamento do consumidor no contexto dos estudos psicológicos.

Nas escolas de Marketing e Comunicação, duas são as disciplinas que se aproximam dos estudos psicológicos: Comportamento do Consumidor, para estudos específicos sobre estratégias de abordagem do consumidor a partir das teorias psicológicas, e Psicologia da 
Comunicação, que estuda, além das teorias psicológicas, a relação entre a psicologia e a mídia.

Diante desse percurso, a proposta desta pesquisa de mestrado vem ao encontro do surgimento de um consumidor mais crítico e disposto a se tornar uma voz mais ativa diante das imposições de mercado. Esse novo consumidor tem exigido dos profissionais da área uma nova forma de concebê-los, estudá-los e abordá-los. As novas tendências da área de Marketing, que serão apresentadas no contexto desse estudo, indicam a necessidade de se reconhecer a "pessoa no consumidor", de forma a contribuir para a diminuição das distorções provocadas pelo avanço do consumismo e das práticas predatórias de mercado.

Dessa forma, o trabalho que será apresentado foi estruturado a partir de quatro capítulos conforme explicitamos abaixo:

- No capítulo 1, é apresentado o contexto histórico do surgimento do Marketing e da Psicologia do Consumidor, destacando-se a revolução industrial americana e o fortalecimento do desenvolvimento econômico, social e cultural dos Estados Unidos. Os fatores econômicos foram fundamentais para o surgimento da Psicologia Científica americana com o objetivo de contribuir para o fortalecimento da sociedade americana. Também, nesse capítulo, apresentase a cronologia histórica das escolas de pensamento em marketing. A partir desse percurso histórico, ao final do capítulo, elaboramos um quadro-resumo apresentando o desenvolvimento do conceito de consumidor a partir do desenvolvimento da atividade de marketing.

- No capítulo 2, apresentamos o desenvolvimento da Psicologia Científica e da Psicologia do Consumidor nos Estados Unidos, bem como a contribuição dos pioneiros dessa área específica para a área de Marketing e Comunicação, a partir do levantamento bibliográfico de diferentes autores e pesquisadores da Psicologia aplicada ao Marketing e à Publicidade. Após análise da perspectiva histórica de ambas as áreas, apresentamos as ideias predominantes sobre o conceito e o comportamento do consumidor em cada época específica, assim como a aproximação com as teorias psicológicas predominantes naqueles períodos. Nesse capítulo também evidenciamos as tendências de marketing para o início do século XXI, e passamos a discutir o conceito de consumidor no mundo contemporâneo.

- No capítulo 3, foi realizado um estudo sobre a história dos conceitos de pessoa e experiência na Idade Moderna, sobre o conceito de experiência de consumo, e sobre o conceito de Experiência elementar, e como essas diferentes abordagens se relacionam com o conceito de consumidor no marketing contemporâneo. 
- No capítulo 4 é apresentada uma discussão sobre a Experiência elementar, a Psicologia e o Marketing, e como esses temas se relacionam frente às novas tendências da atividade de marketing, falando da importância do papel do consumidor enquanto pessoa, pela análise de alguns exemplos de campanhas publicitárias.

\section{4 - Metodologia}

Esta pesquisa utiliza o método de investigação histórica e está inserida no âmbito da história do Marketing, da Psicologia Científica e da Psicologia do Consumidor, no período que compreende o final do século XIX e o século XX. Nesse contexto foram levantados os principais acontecimentos históricos relacionados à Revolução Industrial e ao avanço do capitalismo na sociedade americana, bem como a contribuição da psicologia científica para o processo de emancipação desse país, o surgimento da Psicologia do Consumidor como área específica, e como o encontro entre essas áreas distintas, Psicologia e Marketing, contribuíram para as mudanças e o desenvolvimento do conceito de consumidor na perspectiva histórica.

A escolha dessa metodologia apoia-se na historiografia da Psicologia Científica, cujos métodos se inserem no domínio da História das Ciências conforme Massimi (2010), que remete ao historiador A. Crombie (1987 citado por Massimi, 2010, p. 105), ao traçar os objetivos da pesquisa nessa área:

[...] a apreensão dos problemas que interessavam os cientistas e que foram solucionados no período histórico escolhido para a investigação; o entendimento das hipóteses, das expectativas e do que os pesquisadores daquela época consideravam como sendo respostas e explicações válidas; o levantamento dos trabalhos bem sucedidos e reconhecidos e das teorias e dos experimentos fracassados, ou que seriam inadequados ou mal percebidos para a nossa mentalidade contemporânea. Segundo o autor, a preocupação principal do historiador das ciências deve ser de "interpretar metas, concepções e soluções do passado tal como se deram no passado". O erro consiste na utilização do "superior conhecimento científico contemporâneo para avaliar descobertas e teorias do passado como antecipações e contribuições ao presente".

Assim, o historiador das ciências, segundo Massimi (2010, p.106), "utiliza os mesmos recursos metodológicos de todo historiador: a saber, as fontes (organizadas por gêneros) e a análise interpretativa", conforme descritos abaixo: 
Os gêneros mais comuns de fontes para estudos históricos em psicologia são: correspondência espistolar; narrativas de viagens, relatórios, catálogos e informes; peças de oratória e documentos ligados à oralidade; narrativas de celebrações (festivas, políticas, religiosas); narrativas de ficção e obras poéticas; tratados (filosóficos, científicos, e das demais áreas das ciências humanas e naturais); manuais para uso didático; artigos em revistas (científicas); artigos em revistas (divulgação); teses e trabalhos acadêmicos de modo geral; currículos e programas escolares.

Massimi (2010) também destaca a importância de conceber os estudos históricos em Psicologia "na perspectiva de um pluralismo metodológico". O historiador "escolhe os métodos mais apropriados para a indagação" (Hilgard, Leary e McGuire, 1998, citado por Massimi, 2010, p.105). Dessa forma, a escolha do método histórico, de onde se derivou a interpretação do conceito de consumidor, a partir da aproximação entre as áreas, e do contexto histórico, relaciona-se ao nosso interesse de desvendar os modos pelos quais as diferentes abordagens do "consumidor" culminaram no conceito de consumidor no mundo contemporâneo. Nesse percurso realizamos, também, um levantamento histórico dos conceitos de pessoa e experiência para relacionar com a abordagem da Experiência elementar, que está sendo usada por diferentes áreas na atualidade, incluindo a psicologia.

A forma de organização da narrativa histórica obedeceu ao interesse de estabelecer um diálogo entre as áreas do Marketing e da Psicologia, especificamente sobre a contribuição desses estudos para o conceito de consumidor.

A seguir, apontamos os passos que foram seguidos, contemplando a pesquisa histórica em psicologia, indicados por Massimi (1998, p.14-29):

Primeiro passo - Definicão do tema e do problema :Massimi (1998, p.28) aponta três "regras" que o historiador deve seguir na escolha do problema a ser investigado: "é preciso ter clareza acerca do fato de que cada problema ou pergunta, para ser respondida, exige métodos e recursos diferentes". Em segundo, "é oportuno que tenhamos certo interesse pelo tema escolhido, pois o interesse é uma mola fundamental ao conhecimento". E, em terceiro, “é oportuna também uma clara delimitação do tema a ser investigado, o que supõe a consciência dos limites". Quanto a isso, a mesma autora destaca que, sendo de natureza metodológica, se o material for muito fragmentado e disperso, não pode ser adotada uma metodologia do tipo quantitativo. A autora salienta, ainda, a questão dos limites dos recursos disponíveis (sobre o estado de conservação da documentação histórica disponível), e a necessidade de imparcialidade da reconstrução histórica. 
Nessa etapa, estabelece-se o "recorte" para esta pesquisa. A partir dos autores e obras da história da Psicologia, da Psicologia do Consumidor e da área de Marketing são abordados os conceitos de consumidor no passado e na contemporaneidade.

Segundo Passo - Como conseguimos o material para investigacão: As fontes relativas à história do Marketing, da Psicologia e da Psicologia do Consumidor, estabelecidas para essa pesquisa, foram utilizadas a partir do acervo da FFCLRP - Faculdade de Filosofia Ciências e Letras de Ribeirão Preto e de outras unidades do câmpus da USP Ribeirão, além de consultas a acervos online em bibliotecas virtuais do Brasil e Estados Unidos. Outras obras que complementaram o estudo foram adquiridas durante o período da pesquisa.

Terceiro Passo - O tratamento das fontes: Nessa etapa, foi utilizado o referencial teórico proposto pela metodologia escolhida, tendo sido a leitura das fontes determinante para se compreender o seu conteúdo como expressão do universo sociocultural da época dos autores.

Quarto Passo - A interpretacão: A interpretação ocorreu a partir dessa fase, depois do amadurecimento das ideias e das leituras propostas para esse trabalho. E aqui, é importante ressaltar que, para recuperar a história dos temas e das obras dos autores, "é necessário acompanhá-la atentamente em todos os seus caminhos, todas as suas formas e todos os seus elementos" (Massimi, 1998 p. 28). Essa reconstrução foi a base para descrever o panorama da discussão sobre o consumidor no mundo contemporâneo.

Quinto Passo - Abordagem da Experiência Elementar: Tendo por horizonte o panorama obtido pela reconstrução histórica, foi desenvolvida a discussão do conceito de consumidor no mundo contemporâneo, que faz parte do objetivo da pesquisa. Nessa etapa, foi abordada a proposta da Experiência elementar e as contribuições dos autores contemporâneos do marketing, já citados nas fontes de pesquisa, para estabelecer o diálogo e a discussão. Também foram analisadas campanhas publicitárias disponíveis na internet.

\section{Fontes relativas à história do Marketing e da Psicologia do Consumidor}

1 - Para delimitar o contexto histórico do Marketing, foram analisados artigos, teses e obras produzidos por acadêmicos brasileiros e internacionais, que pesquisaram de forma sistemática o contexto histórico do surgimento dessa área nos Estados Unidos. É de salientar 
que nos limitamos ao estudo do percurso histórico do Marketing no contexto dos Estados Unidos, por se tratar de um país que, no início do século, se destacou não apenas no desenvolvimento econômico, mas também nas áreas relativas ao desenvolvimento social e cultural. O pragmatismo americano, evidenciado em várias áreas do conhecimento e na sociedade como um todo, permitiu, a consolidação da área de Marketing como ciência e da Psicologia aplicada aos estudos sobre publicidade e marketing.

Também foram acessadas bases de dados em bibliotecas e livrarias virtuais. Como o nosso objetivo não foi uma reconstrução detalhada da história do Marketing, mas sim evidenciar a partir dela, o desenvolvimento do conceito do consumidor, partimos de alguns autores para realizar um breve levantamento histórico sobre essa área específica. Entre eles citamos Bartels (1970) ${ }^{5}$, que classificou os períodos históricos como escolas de pensamento, além de Sheth et al. (1988) ${ }^{6}$, que também analisou as escolas de pensamento, utilizando uma nomenclatura mais contemporânea realizando, assim, uma classificação mais precisa até o final do século XX.

Elaboramos gráficos e tabelas para apresentar o contexto histórico, considerando as seguintes variáveis: ano/período, autores representativos, características de cada escola de pensamento e o conceito de consumidor predominante em cada período.

Sheth et. $\mathrm{al}^{7}$ (1988, citado por Ajzental, 2010, p. 6) argumentou que uma escola de pensamento em marketing deve seguir os seguintes critérios:

- apresentar um foco distinto e relevante às metas e aos objetivos de marketing, especificando quem se beneficia ou deveria se beneficiar da atividade de marketing e de sua prática;

- apresentar uma perspectiva sobre e porque a atividade de marketing é conduzida ou deveria ser conduzida pelos stakeholders ${ }^{8}$.

\footnotetext{
${ }^{5}$ O professor Robert Bartels, Ph.D., na época da publicação dos livros "Marketing Theory and Metatheory" (1970) e "The History of Marketing Thought"(1976), era professor da disciplina de Marketing da Ohio State University, EUA. A evolução do Marketing, a partir das escolas de pensamento, revolucionou os estudos históricos de Marketing. Alguns autores passaram a classificar os estudos históricos a partir de duas abordagens: a história do pensamento em marketing e a história do marketing.

${ }^{6}$ Jagdish N. Sheth é professor de Marketing da Goizueta Business School e fundador do Center for Relationship Marketing na Emory University. Antes disso, ele era um membro do corpo docente da Universidade do Sul da Califórnia, a Universidade de Illinois, da Universidade de Columbia e do Instituto de Tecnologia de Massachussetts. Professor Sheth já publicou mais de 200 livros e trabalhos de pesquisa em diferentes áreas de marketing e estratégia de negócios. Muitos deles são considerados referências clássicas. Seu livro The Theory of buyer behavior (1969), escrito com John A. Howard, é considerado um clássico dos estudos sobre comportamento do consumidor e marketing. É também co-autor de Marketing Theory: evolution and evaluation (1988) e Consumption values and market choices (1991). É membro da APA - American Psychological Association e ex-presidente da Consumer Psychology Division and Association for Consumer Research, filiadas à instituição. Disponível em: http://www.jagsheth.net/ acessado em 12 de fevereiro de 2013.

${ }^{7}$ Sheth, J.N.; Gardner, D. M \& Garrett, D. E. (1988). Marketing theory: evolution and evaluation. New York: John Wiley \& Sons.

${ }^{8}$ Públicos de interesse. Tradução nossa.
} 
Para Bartels (1970), uma escola de pensamento não deve ser avaliada em relação ao seu caráter passado ou futuro, mas em relação às "circunstâncias simultâneas que produzem aquela fase de pensamento". Nesse sentido, o desenvolvimento de um pensamento não é uma variável independente, mas sim dependente de outros fatores que colaboram para seu aparecimento e amadurecimento como forma de pensamento. Segundo essa perspectiva, o conceito de consumidor pode estar diretamente vinculado à respectiva escola de pensamento à qual pertence num dado momento, segundo variáveis econômicas, sociais e históricas.

As escolas de pensamento em marketing foram classificadas segundo o período histórico e, principalmente, quanto ao grau de influência de um pensador pioneiro que lançou suas ideias através da publicação de um artigo ou livro. Para classificar as diferentes escolas e atender ao objetivo principal desse trabalho, são apresentadas análises parciais de cada período.

Ressaltamos que alguns pesquisadores da área de Marketing apontam dúvidas e questionamentos acerca da divisão dos períodos em escolas de pensamento. Um dos pontos fracos, talvez, seja a ausência de avaliação e análise das teorias propostas em cada época distinta das escolas de pensamento (Santos et. al, 2009, p. 101). Miranda e Arruda (2004, p. 41) nos orientam quanto a esses cuidados:

Teóricos da área não atentam para a necessidade de criticar consistentemente outras teorias, a fim de identificar forças e fraquezas antes de formular seus próprios modelos. Observa-se, frequentemente, um desconhecimento da existência e conteúdo das principais escolas desenvolvidas no passado. Ademais, mesmo conhecendo tais princípios, aceitam-se como valiosos, sem questioná-los, através de um estudo cuidadoso.

Outros pesquisadores preferem abordar "o desenvolvimento do marketing de uma forma mais abrangente, dividindo sua história em três eras distintas" (Las Casas, 2001; Rocha \& Chirstensen, 1999, citado por Santos et. al, 2009, p. 94). Dessa forma, a classificação segundo as eras do marketing, subdivide-se em: era da produção (a partir do início do século, com foco na produção para ampliar a oferta dos produtos); era de vendas (a partir de 1930, gerando ênfase nas vendas, estimulando a concorrência e a oferta de produtos); e a era do marketing (a partir da década de 1950, em que os empresários começam a perceber a importância e o papel do consumidor no processo de decisão da compra).

Ambler (2004, p. 2) afirma que a área de Marketing, por ter sido historicamente constituída a partir da interdisciplinaridade de diferentes áreas e profissionais, pode ter colaborado para a ampliação dos seus estudos (Santos et. al, 2009, p. 100). Exemplificando: 
um economista, ao estudar Marketing, pode analisar a atividade mais voltada às questões econômicas, enquanto um psicólogo poderá relacionar a área às influências psicológicas no comportamento do consumidor.

Para essa pesquisa, relacionamos as escolas de pensamento de acordo com as propostas dos autores, partindo da contribuição interdisciplinar como sendo fundamental para a constituição da área de Marketing.

2 - Para delimitar o contexto histórico da Psicologia do Consumidor, levantamos a bibliografia dos psicólogos que, através da psicologia aplicada aos estudos sobre comportamento do consumidor, a partir do início do século XX até o início do século XXI, nos Estados Unidos, influenciaram com suas teorias os estudos de marketing e publicidade. Esses autores, em diferentes épocas e contextos históricos, escreveram obras e desenvolveram pesquisas a respeito desses temas. As bases teóricas para esse contexto foram: Haugtvedt et. al (2008, p. 3 a 28), uma obra que contém uma coletânea de artigos de pesquisadores da área da psicologia e comportamento do consumidor, incluindo o contexto histórico da área e as pesquisas recentes da psicologia do consumidor; Blackwell et. al (1968/2005, p. 71-102), que publicou na década de sessenta uma obra didática contendo modelos referenciais para os estudos sobre o comportamento do consumidor. Nesse mesmo período histórico da publicação original de Blackwell, a $\operatorname{APA}^{9}$ (American Psychology Association), criou a Divisão 23 (Divisão de Psicologia do Consumidor) em seu estatuto, legitimando a área de pesquisa em comportamento do consumidor no contexto dos estudos de Psicologia.

Para complementar a contextualização histórica, apresentamos um breve relato sobre o desenvolvimento da psicologia científica nos Estados Unidos. Para esse estudo, usamos manuais de história da Psicologia e Marketing, recomendados para pesquisa acadêmica, conforme bibliografia citada no final desse trabalho.

\footnotetext{
${ }^{9}$ A Associação Americana de Psicologia é a maior organização científica e profissional que representa a psicologia nos Estados Unidos, sendo também a maior associação de psicólogos do mundo, com mais de 137 mil pesquisadores, educadores, médicos, consultores e estudantes como seus membros. A APA foi fundada em julho de 1892 na Clark University. Seu primeiro presidente foi G. Stanley Hall e começou com 31 membros. Após a Segunda Guerra Mundial, ela se expandiu rapidamente. Hoje a APA tem 54 divisões em subcampos da psicologia e mais de 150.000 membros. Retirado do World Wide Web <http://www.apa.org/about/archives/apahistory.aspx > em 12 de fevereiro de 2013.
} 


\section{Fontes relativas ao conceito de pessoa, experiência e Experiência elementar:}

Nos capítulos 3 e 4 foi realizada a discussão sobre o conceito de consumidor no mundo contemporâneo, usando a abordagem da Experiência elementar proposta por Luigi Giussani (2009) ${ }^{10}$, em sua obra $O$ senso religioso (2009).

Recorremos à abordagem da Experiência elementar a partir de Giussani (2009), que analisa com profundidade a trajetória da realização humana e procura, através de suas experiências com a realidade, compreender o ser humano de forma mais completa.

Giussani desenvolveu seu trabalho analisando principalmente as transformações humanas na modernidade. A justificativa da escolha dessa obra é que, no marketing contemporâneo, alguns autores sugerem a utilização do termo "pessoa" para se referir ao consumidor, mas sem conhecimento e aprofundamento filosóficos e antropológicos para esses estudos. Diante da nova tendência, e entendendo que se trata de um percurso interessante e necessário para a atividade de marketing, partimos para o estudo específico sobre os conceitos de pessoa, experiência, experiência de consumo e experiência elementar, e das maneiras pelas quais isso poderia ter implicações para a atividade de marketing. É importante destacar que os estudos sobre a abordagem da Experiência elementar também estão sendo utilizados nas práticas terapêuticas e clínicas da Psicologia, além de outras áreas das ciências humanas, como a Pedagogia.

Para fundamentar a relação entre os conceitos de pessoa, experiência, experiência de consumo, e experiência elementar, recorremos a autores específicos que pudessem complementar nossos estudos:

- Assim, para o estudo sobre o conceito de pessoa, utilizamos o pensamento de Romano Guardini (1885-1968), filósofo e educador. Suas reflexões sobre os questionamentos das pessoas frente aos desafios do mundo moderno estão presentes em duas obras do autor: $O$ mundo e a pessoa (1963) e O fim dos tempos modernos (citado por Brandão, 2005).

- Para o estudo sobre o conceito de experiência, utilizamos os trabalhos de Massimi e Mahfoud (2007), Mahfoud e Massimi (2008), e Gaspar e Mahfoud (2006).

\footnotetext{
${ }^{10}$ Em toda a sua trajetória como educador focou a centralidade da pessoa e o sentido de ser humano de uma forma que ultrapassava os limites étnicos e religiosos. Suas obras foram e continuam a ser estudadas por diferentes gerações de jovens do mundo inteiro. Um fato marcante foi o lançamento de sua obra "O senso religioso", em inglês, no ano de 1977, em que representantes de várias origens, entre budistas, judeus e católicos, manifestaram o reconhecimento por seu trabalho e sua proposta de análise e conhecimento da trajetória humana. Luigi Giussani também dedicou boa parte de seu conhecimento ao ensino universitário, e tinha na educação a experiência concreta de suas propostas e conceitos.
} 
- Para o estudo sobre o conceito de experiência de consumo, utilizamos Schmitt (1999), psicólogo, estudioso da área de comportamento do consumidor, que criou o termo "experiências de consumo" se remetendo as experiências vividas pelos consumidores em contato com as diferentes marcas de produtos e serviços, na obra Marketing Experimental (1999).

- Para o estudo sobre a abordagem da Experiência elementar, utilizamos do livro $O$ Senso Religioso, os seguintes capítulos: 1 - Primeira Premissa: Realismo; 2 - Segunda Premissa: Razoabilidade; 3 - Terceira Premissa: Incidência da moralidade sobre a dinâmica do conhecimento; 4 - Senso religioso: o ponto de partida e, a obra Experiência elementar em Psicologia: aprendendo a reconhecer.

A fundamentação a partir dessas obras e da abordagem da Experiência elementar nos ajudou a analisar a aproximação entre os termos, partindo do conceito de pessoa na Idade Moderna e dos estudos antropológicos e filosóficos de Guardini; do conceito de experiência no contexto da história das ciências e sua apropriação pela psicologia científica; do conceito de experiência de consumo como sendo uma prática da atividade de marketing que estimula o contato com os produtos a partir de motivações externas; e da abordagem da experiência elementar como um estudo que define o núcleo da experiência humana.

Para a discussão final sobre a Experiência elementar, Psicologia e Marketing e de como esses temas se relacionam com o conceito de consumidor no mundo contemporâneo recorremos a exemplos de campanhas publicitárias, disponíveis em sites da área de Comunicação e Marketing, que entendemos se aproximarem da proposta da Experiência elementar pela forma como os consumidores são abordados. 



\title{
2. O CONTEXTO HISTÓRICO
}

\section{1 - O contexto histórico do surgimento do Marketing e da Psicologia do Consumidor.}

Os Estados Unidos, no final do século XVIII, era uma jovem nação que comemorava a sua independência (1776) e surpreendia os países do continente europeu com os seus ideais de liberdade e de desenvolvimento econômico. Apoiados pelos ensinamentos iluministas ${ }^{11}$, os americanos foram motivados por um genuíno espírito revolucionário e se uniram em torno do ideal da construção de um país soberano e legitimado pelo esforço e compromisso mútuo de toda a sociedade.

Arendt (1906-1975), filósofa de origem alemã que, radicada nos Estados Unidos desde a década de 1940, analisou na obra Sobre a Revolução (1963) ${ }^{12}$ a importância dos movimentos revolucionários que marcaram profundamente o desenvolvimento social e político dos americanos e franceses. Nessa obra, apresentou como as conquistas da revolução americana foram significativas para a origem e a consolidação como república desse país, que "passou a existir em consequência de um ato deliberado de fundação da liberdade" (Sadek, 1989).

\begin{abstract}
A direção da Revolução Americana permaneceu comprometida com a implantação da liberdade e o estabelecimento de instituições duradouras e, àqueles que atuavam nessa direção, nada era permitido que estivesse fora do âmbito da lei civil. O rumo da Revolução Francesa foi desviado desse curso original, quase desde o início, pela urgência do sofrimento; isso foi ocasionado pelas exigências da libertação, não da tirania, mas da necessidade, e impulsionado pelas ilimitadas proporções da miséria do povo e pela piedade que essa miséria inspirava (Arendt, 1963, p. 73 citado por Sadek, 1989, p. 215).
\end{abstract}

O compromisso e o espírito de desenvolver a nação marcaram profundamente o ideal americano e, especificamente, o avanço econômico que se refletiu em diferentes áreas da sociedade.

\footnotetext{
${ }^{11}$ Os ideais iluministas. Os pensadores que defendiam estes ideais acreditavam que o pensamento racional deveria ser levado adiante substituindo as crenças religiosas e o misticismo, que, segundo eles, bloqueavam a evolução do homem. O homem deveria ser o centro e passar a buscar respostas para as questões que, até então, eram justificadas somente pela fé. Retirado do World Wide Web <http://www.suapesquisa.com/historia/iluminismo/> em 17 de fevereiro de 2013.

${ }^{12}$ Publicada em 1963, nessa obra a filósofa alemã discute as ideias sobre liberdade relacionada às questões políticas da modernidade e analisa a importância das revoluções para a consolidação da modernidade a partir das duas grandes revoluções do século XVIII: a Revolução Americana e a Revolução Francesa. Retirado do World Wide Web <http://educacao.uol.com.br/biografias/hannah-arendt.jhtm> em 12 de fevereiro de 2013.
} 
Até o século XVIII, a economia de mercado era realizada à maneira tradicional, do produtor para o consumidor. O processo de fabricação era realizado de forma artesanal, sem a utilização de processos mecânicos e planejamento. A Inglaterra e o continente europeu avançavam para o desenvolvimento de um sistema econômico pautado pelo advento tecnológico industrial e amadureciam as bases para a ampliação de suas riquezas no continente americano. Os Estados Unidos, que até meados desse século ainda era uma colônia inglesa, tentava manter-se unido e reivindicava a sua independência econômica, política e cultural.

O desenvolvimento econômico americano começou a dar sinais de crescimento a partir de dois movimentos originados no continente europeu: a Revolução Industrial na Inglaterra (1780) e a consolidação das bases da economia capitalista a partir da publicação dos fundamentos da teoria econômica de Adam Smith (1723-1790). Em 1776, o autor publicou A Riqueza das Nações ${ }^{13}$, e revolucionou os modelos de produção econômica quando lançou as bases para o desenvolvimento dos mercados, marcando profundamente as relações comerciais e o modo de vida dos ambientes urbanos.

James Watt (1736-1819), em 1769, inventou a primeira máquina a vapor e aperfeiçoou o sistema manufatureiro, principalmente na produção de tecidos, inovando ao utilizar o vapor como uma nova forma de energia. A máquina de Watt possuía "especificações extremamente precisas, em que o impulso retilíneo de um pistão podia ser convertido em movimento rotativo. Um fabricante de Birmingham, chamado Boulton interessou-se pelo projeto e associou-se a Watt" (Hunt \& Sherman, 1990, p.55). Gradativamente, a força humana na produção industrial passou a ser substituída pelas máquinas, lançando a produção em larga escala e, consequentemente, inaugurando uma nova era do consumo - o consumo de massa.

As ideias do sistema capitalista de Smith (1776) colocavam em pauta que a prosperidade econômica estava no desenvolvimento dos mercados e na capacidade produtiva. Estimulava a concorrência e o desenvolvimento da indústria como elementos essenciais para o desenvolvimento da sociedade. Sobre esse pensamento, afirmaram Hunt \& Sherman (1990):

\footnotetext{
${ }^{13}$ A Riqueza das Nações - Nesta obra Adam Smith buscou diferenciar a economia política da ciência política, a ética e a jurisprudência. Fez também duras críticas à política mercantilista e sua intervenção irrestrita na economia. Porém, a teoria principal defendida por Adam Smith nesta obra é a de que o desenvolvimento e o bem estar de uma nação advêm do crescimento econômico e da divisão do trabalho. Esta última garante a redução dos custos de produção e a queda dos preços das mercadorias. Defende também a livre concorrência econômica e a acumulação de capital como fonte para o desenvolvimento econômico. Retirado do World Wide Web <http://www.suapesquisa.com/biografias/adam_smith.htm> em 17 de fevereiro de 2013.
} 
Para Adam Smith, a propriedade econômica dependia da capacidade produtiva da economia. A capacidade produtiva, por sua vez, dependia da acumulação de capital e da divisão do trabalho. Se um homem produzisse tudo o que ele e sua família necessitavam, a produtividade permaneceria extremamente baixa. No entanto, se os homens dividissem entre si tarefas, e cada um se dedicasse unicamente à produção da mercadoria para a qual estivesse melhor capacitado, a produtividade naturalmente aumentaria. A divisão de tarefas pressupunha a existência de um mercado onde os diversos produtos pudessem ser trocados. Cada indivíduo compareceria ao mercado para adquirir os bens de que necessitava, mas que não produzia (p.62).

Nesse contexto as atividades comerciais e industriais passaram a ser o ponto principal do desenvolvimento das grandes cidades. Com o aumento da produção, surgiu a necessidade de aumentar a demanda e divulgar, através de publicidade, os produtos e serviços que estavam sendo comercializados. A publicidade consolidou-se nessa época como um reforço importante atrelado ao desenvolvimento econômico. Antes, na fase pré-industrial, seu objetivo era meramente informativo. Com o advento do pensamento econômico voltado ao desenvolvimento dos mercados, a publicidade passou a ser "[...] motivadora. O fabricante precisa motivar o consumidor, precisa apelar a ele para que compre o seu produto e não outro produto qualquer" (Cabral, 1926/1986, p. 21).

Foi nesse cenário de grandes mudanças que a nação americana se destacou no início do século, como um país que precisava se desenvolver, beneficiando-se do surgimento das fábricas, do comércio e das instituições de ensino que focavam na formação de profissionais capazes de concretizar o desenvolvimento do país. Em diferentes áreas, o esforço era para unificar e lançar as bases para um futuro promissor com destaque para a soberania econômica americana.

Na virada do século XIX, pesquisadores americanos das áreas relacionadas aos mercados consumidores, atentos ao desafio de contribuir para o crescimento dos Estados Unidos, passaram a estudar com mais cuidado as questões comportamentais com o objetivo de entender de uma forma mais ampla o modo de reagir dos consumidores ao crescimento dos mercados e aumento do consumo. No ambiente acadêmico, cresciam as escolas de formação em negócios, comércio e ciências sociais aplicadas.

A escola econômica clássica focava, segundo Simões (1976), somente dois fatores do processo econômico como sendo realmente importantes: a produção e a distribuição, sendo esta última, "um mero apêndice da primeira" (p.16). Quando os mercados emergentes do início do século XX, principalmente nos Estados Unidos, alcançaram bons resultados de produção (pelo desenvolvimento tecnológico e das indústrias da época), e a produção passou 
a se igualar à demanda e, em alguns casos, superá-la, surgiu a necessidade de técnicas de vendas mais agressivas, propaganda e pesquisas de mercado. Foi nesse momento, a partir da década de 1920, que os fabricantes passaram a se preocupar com o crescimento da produção e como o mercado passaria a se comportar com uma oferta de diferentes produtos e marcas. Nesse período surgiram as primeiras ideias sobre o conceito de marketing.

Para Bartels (1976), o desenvolvimento do pensamento em marketing começou no início do século XX, estimulado pelo desenvolvimento econômico e pela necessidade de fortalecimento dos mercados, quando os primeiros estudantes foram formados a partir da escola econômica. As ideias do pensamento econômico ganharam adeptos no ambiente acadêmico das principais universidades, mas aos poucos, o sentido mais amplo do Marketing como ciência e como pensamento logrou definição própria, passando a ser estudado como uma área específica de estudos sobre as relações de mercado.

A evolução do mercado, a melhoria da capacidade de produção industrial e a sua ampliação exigiram uma nova abordagem do Marketing. Os primeiros estudantes e professores de marketing, nas escolas de negócios da década de 1920, passaram a estudar essa área separadamente da área da economia, com o foco nas atividades de mercado. E foi nesse momento (década de 1920) que o Marketing, antes apenas uma disciplina da Economia, passou a ter o status de uma área de estudos independente.

Paralelamente ao desenvolvimento da nova área de estudos de mercado, os estudos sobre o comportamento humano despertaram o interesse de gerações de pesquisadores em diferentes áreas do conhecimento. No início do século XX, especificamente durante a efervescência da revolução industrial americana, as questões econômicas, psicológicas e sociais, presentes nas relações de consumo, passaram a ser estudadas por diferentes autores.

Devido ao cenário econômico, muitas oportunidades surgiram para que outros profissionais, entre eles os psicólogos, aplicassem seus conhecimentos e técnicas nas atividades relacionadas ao dia a dia das pessoas. Sobre essa questão afirmou H. Hollingworth, [...] "passei a adotar a psicologia aplicada para ganhar a vida" (1985, O’Donnell, p. 225 citado por Schultz \& Schultz, 2005, p. 10).

Especificamente em solo americano, no final do século XIX e início do século XX, os fatores econômicos foram fundamentais para o surgimento de uma Psicologia que, de certa forma, contribuísse para a formação dessa sociedade e estimulasse os estudos sobre o comportamento. Apesar de a Psicologia Científica ter nascido na Alemanha, foi nos Estados Unidos que ela encontrou espaço para um rápido crescimento atrelado aos ideais econômicos e de desenvolvimento da sociedade. 
As condições presentes nos Estados Unidos, que favoreceram o desenvolvimento da Psicologia nesse período e que contribuíram para a transformação da sociedade desse país foram principalmente, segundo Ferreira \& Gutman (2011): “a) as necessidades políticas e administrativas decorrentes de um processo de modernização avançado próprio àquele país; e b) as características do sistema universitário norte-americano no final do século XIX" (p. 122).

A modernização apoiou, num certo sentido, o desenvolvimento educacional e universitário. Nesse contexto, a psicologia passou a ter um papel ativo, conforme Ferreira \& Gutman (2011) "classificando, selecionando e ajustando os indivíduos a esses novos espaços - as escolas e as fábricas - e auxiliando no bom uso da sua liberdade nesse admirável mundo novo" (p. 123).

A semente para a formação das gerações de pesquisadores estava em duas principais universidades americanas: Columbia University e University of Chicago e, ao contrário das universidades europeias, tradicionais em suas origens e estudos nas áreas de Filosofia e Ciências Humanas, os estudos psicológicos em solo americano se expandiram, em parte, fruto do fortalecimento do capitalismo e do aumento das universidades:

No final do século XIX o número de laboratórios de psicologia nos Estados Unidos crescia continuamente, ao mesmo tempo em que aumentava o número de psicólogos em busca de oportunidades de trabalho. Por volta de 1900, havia três vezes mais psicólogos com doutorado do que laboratórios onde pudessem trabalhar. Felizmente, o número de vagas para professores aumentava à medida que os Estados do meio-oeste e oeste criavam as universidades. Entretanto, sendo uma ciência muito recente na maioria delas, a psicologia recebia a menor verba orçamentária. Comparado aos demais departamentos, como os da física e química, o de psicologia, muitas vezes, era o que apresentava o menor orçamento anual, isto é, recebia a menor verba para os projetos de pesquisa, equipamentos de laboratório e salários do corpo docente (Schultz \& Schultz, 2005, p. 10).

Os primeiros psicólogos americanos foram alunos de Wilhelm Wundt (1832-1920), mais especificamente em Leipzig, Alemanha, a partir do ano de 1879, quando foi fundado o seu laboratório naquela instituição. Passados pouco mais de vinte anos do início da psicologia científica na Europa, os psicólogos americanos já tinham assumido uma liderança na área. Em seu discurso como presidente da American Psychology Association (APA), no ano de 1896, James Mckeen Cattell (1860-1944), declarou: 
Não há precedentes na história comparáveis ao desenvolvimento acadêmico da psicologia nos Estados Unidos, ao longo dos últimos cinco anos [...]. A psicologia é matéria obrigatória nos currículos de graduação [...] e, hoje, entre os diversos cursos universitários, concorre com as outras grandes ciências, em número de estudantes interessados e na quantidade de trabalhos originais realizados (Cattel, 1896, pp. 134-148, citado por Schultz \& Schultz, 2005, p.185).

A popularização da Psicologia foi alavancada principalmente pelo espírito americano da época. A psicologia experimental de Wundt foi ampliada em solo americano e fundamentou as bases para a psicologia funcionalista. Muito além dos experimentos em laboratório, a psicologia funcionalista americana passou a se preocupar com os problemas humanos em decorrência das questões sociais, econômicas e culturais da época. Nesse contexto, a psicologia passou a ser ensinada em vários cursos e foi aplicada nas pesquisas que envolviam as áreas da educação, forças armadas e comércio.

Um exemplo da aproximação da Psicologia com outras áreas do conhecimento, mais especificamente na área da Publicidade, foi o uso de novas técnicas na forma de conceber, criar e veicular anúncios publicitários no início do século. Harlow Gale (1862-1945), na Universidade de Minnesota, em 1896, começou a conduzir experimentos a respeito das publicidades (Coon, 1994, p. 44) e, em seus experimentos, analisou a questão do uso das cores e a relevância das palavras bem como as suas influências na decisão do consumidor. Ao relacionar imagens e palavras para reforçar a mensagem, sugeria uma abordagem do consumidor mais direcionada, na tentativa de estimular a mudança do comportamento de consumo do produto ou serviço anunciado. Por exemplo, ao anunciar uma bebida, era usada a imagem de uma pessoa consumindo a bebida. Essa técnica funcionava como um estímulo visual para estimular a compra.

E foi nesse panorama de desenvolvimento econômico que a psicologia americana se fortaleceu e desenvolveu suas bases para uma psicologia aplicada, para atender a demanda das questões econômicas e sociais e, também, para ampliar as funções profissionais dos jovens estudantes das escolas de psicologia. Foi ainda nesse contexto que tiveram origem os primeiros estudos sobre a psicologia do consumidor aplicados a publicidade e ao marketing. 


\section{2 - O conceito de consumidor: cronologia histórica a partir das escolas do pensamento em marketing e a contribuição dos pioneiros da psicologia aplicada a partir do início do século XX nos Estados Unidos até o início do século XXI.}

Marketing é uma palavra inglesa que não possui uma tradução específica na língua portuguesa, mas que passou a ser incorporada como neologismo no meio acadêmico e de negócios do mercado. Possui um significado amplo, pois integra várias atividades que têm como objetivo principal organizar, planejar e criar mecanismos para orientar os mercados, com o objetivo de desenvolver os processos de troca e satisfazer as necessidades dos clientes consumidores.

O escopo do marketing é inquestionavelmente amplo. Com frequência, inclui assuntos de diversas áreas, como comportamento do consumidor, precificação, compras, gerenciamento de vendas, gerenciamento de produto, comunicação de mercado, Marketing comparativo, Marketing social, eficiência/produtividade dos sistemas de Marketing, ética em Marketing, papel do Marketing no desenvolvimento econômico, questões sociais em Marketing, varejo, atacado, responsabilidade social do Marketing, Marketing internacional, Marketing de commodities e distribuição física. Essa lista, apesar de vasta, não exaure todas as possibilidades (Ajzental, 2010, p. 4).

O primeiro registro científico da palavra marketing, segundo Bechara $(2007)^{14}$, ocorreu nos Estados Unidos, em 1902, com a junção da palavra market (mercado) com a terminação ing, que determina o modo gerúndio da língua inglesa (e caracteriza movimento permanente). Segundo o mesmo autor, a compreensão da palavra na língua portuguesa poderia ser "mercado em movimento ou ação exercida no mercado".

Foi também no ano de 1902 que surgiu o primeiro curso ligado à área de Marketing, na Universidade de Michigan. Existem registros históricos do aparecimento desse mesmo curso na Universidade de Illinois, como sendo o primeiro curso. Essa discordância aparece, pois, segundo Weld e Hagerty (citado por Bacellar \& Ikeda, 2011, p.490) à época a disciplina recebia os nomes de: Commerce and Trade e Distribuição de Produtos Industriais tendo ambas as escolas registro desses cursos (citado por Bacellar \& Ikeda, 2011, p. 490).

Para Hagerty (citado por Bacellar \& Ikeda, 2011, p. 490), da Ohio State University, antes de 1900 existiam três escolas de Administração de Negócios com cursos de natureza genérica nos Estados Unidos: a Warton School, da Universidade da Pensilvânia, organizada

\footnotetext{
${ }^{14}$ Retirado do World Wide Web <http://www.mundomarketing.com.br> em 10 de dezembro de 2012. Publicado em: 22 de maio de 2007.
} 
em 1881, e as Universidades da Califórnia e de Chicago, em 1898. Após 1900, outras escolas passaram a ter cursos de Administração em cadeiras mais específicas. Entre elas destacaramse grupos de pesquisadores na University of Wisconsin, a partir das escolas de economia, o grupo da University of Harvard, formado por pesquisadores que contribuíram de forma significativa para o desenvolvimento dos princípios de marketing, e o grupo da New York University, que também contribuiu para o desenvolvimento da literatura em marketing.

O lançamento de três obras, segundo Hagerty (1936a), contribuiu para o avanço do ensino da disciplina: Advertising as a Business Force, de Paul T. Cherington (1913), Marketing of Farm Products, de L. D. H. Weld (1915) e An Approach to Business Problems, de Arch W. Shaw (1916).

O percurso histórico da disciplina e área de Marketing é apresentado, segundo diferentes autores, como parte do contexto histórico do desenvolvimento econômico dos Estados Unidos. Nesse sentido, alguns apresentam como "eras" da evolução do marketing (Wilkie \& Moore, 2003) e, outros como escolas de pensamento em marketing (Bartels, 1976; Sheth et. al, 1988).

Para essa dissertação, utilizamos o percurso histórico a partir das escolas de pensamento em Bartels (1970/1976) e Sheth et. al (1988), pois entendemos que, dessa forma, as análises contemplam não só as circunstâncias históricas, mas os princípios e diretrizes de abordagem do nosso ponto fundamental de estudo: a evolução do conceito de consumidor.

Bartels $^{15}$ (1976) foi um dos pioneiros da literatura da área de Marketing que propôs a divisão de momentos históricos a partir do conceito de escolas de pensamento, identificando oito escolas. Sheth et. al (1988) realizou um trabalho semelhante ao de Bartels, ao identificar doze escolas de pensamento em marketing surgidas ao longo do século XX.

A origem do pensamento em marketing, segundo Bartels ${ }^{16}$ (1970), foi marcada pelas influências e circunstâncias históricas do período de 1900 a 1923, mais especificamente pela formação dos primeiros grupos de alunos dessa área nos Estados Unidos. Esses alunos e professores foram motivados pelas influências econômicas e acadêmicas dessa época.

\footnotetext{
${ }^{15}$ Em 1976, Robert Bartels, escreveu a "História do Pensamento em Marketing”, retomando o percurso histórico, principalmente a partir da contribuição de pesquisadores, do nascimento do marketing como ciência e do surgimento de cursos específicos de Marketing. O autor faz uma análise do desenvolvimento da área até meados dos anos setenta e projeta seu pensamento para o ano de 1980, prevendo as ideias que seriam dominantes nessa fase.

${ }^{16}$ Robert Bartels, Ph. D em 1970, professor de Marketing da Ohio State University, publicou através da American Marketing Association uma coletânea de artigos "Marketing Theory and Metatheory", posicionandose claramente a favor da visão de marketing como ciência.
} 
Acerca das dimensões do pensamento em marketing, Bartels (1970) apontou que nos primórdios da disciplina foram influenciados pelos seguintes fatores: dimensão intelectual, fundamentada no caráter científico e filosófico; dimensão temporal, que indicava a relação com o tempo histórico do seu desenvolvimento; dimensão espacial e o seu caráter de universalidade; dimensão interdisciplinar, que indicava a sua relação com outras áreas da ciência social, além da dimensão espiritual, que indicava a extensão com a qual o desenvolvimento do pensamento em marketing coincidia com as questões éticas, que se destacaram no início do século XX.

No que diz respeito à dimensão interdisciplinar, a relevância das ideias das ciências sociais colaborou para o desenvolvimento do pensamento em marketing, sobretudo quanto à abordagem do conceito de consumidor. No início, as questões relacionadas ao comportamento de compra e ao consumidor estavam restritas apenas às relações comerciais, sem o foco nos interesses específicos dos consumidores. Com o aumento da concorrência e do número de fabricantes e marcas, novas possibilidades se abriram para a área de Marketing, e os profissionais e estudantes passaram a se interessar, sobretudo pelas pesquisas em Psicologia aplicada ao campo da Publicidade.

Em alguns centros de pesquisa e universidades, a proximidade entre as áreas da Psicologia e do Marketing se deram através de professores que ministravam disciplinas específicas de psicologia nas escolas de comércio. Foi o caso da Universidade de Northwestern, onde Walter Dill Scott (1869-1955), psicólogo, ministrava aulas para os estudantes do curso de administração e negócios no ano de 1903.

A interdisciplinaridade na área de Marketing foi relevante para o fortalecimento e consolidação da área. Bartels (1970) afirma:

As potencialidades de cooperação entre os estudantes de marketing e outros cientistas sociais foram vislumbradas. Os progressos nesse sentido podem resultar, eventualmente, na elevação de cada uma destas ciências a um nível superior e para o desenvolvimento de um entendimento unificado do comportamento humano em todos os seus aspectos. O valor de tal cooperação para o estudo do marketing neste momento seria ótimo. Assim o pensamento em marketing pode tornar-se não apenas uma ciência da área de negócios, mas, em maior medida, verdadeiramente uma ciência da sociedade. [...] Da psicologia podem ter sido emprestados conceitos tais como: motivação e comportamento, aprendizagem, emoção, os hábitos, a inteligência, projeção, racionalização e agressão. Da economia vieram conceitos como: escala de operação, a concorrência no preço, especialização, custos de oportunidade, concorrência monopolística, e receita marginal e média e os custos. Assim, a interdisciplinaridade foi um importante fato para o desenvolvimento do pensamento em marketing $[\ldots]^{17}$ (p. 135).

\footnotetext{
${ }^{17}$ Tradução nossa.
} 
Nesse contexto, destacamos a importância da aproximação dos estudos psicológicos para a área de Marketing. Para Fontenelle (2008) a "compreensão do comportamento do consumidor a partir da psicologia” (p. 149), surgiu no momento em que o Marketing, como disciplina e área, tornou-se mais independente da economia e as questões sobre o consumo e o comportamento de compra se tornaram mais evidentes para os homens de negócios. No percurso histórico, apesar de receber influência dos psicólogos desde o início do século, foi somente a partir da década de 1950 que a psicologia, como estudo do comportamento humano, passou a contribuir de forma oficial para a atividade de Marketing.

Bartels (1976) e Sheth (1988) identificaram e classificaram as escolas do pensamento em marketing no século XX. A seguir, usamos a classificação de Sheth, elaborada por Miranda e Arruda (2004) que apresentaram, além das características dos períodos, a relação dos autores precursores de cada época. Na coluna ao lado incluímos a classificação de Bartels (1976) com o objetivo de comparar a classificação proposta pelos autores:

\begin{tabular}{|c|c|c|}
\hline Período & Sheth (1988) & Bartels (1976) \\
\hline Escola Commodity & $\begin{array}{l}\text { Primeira escola da disciplina de } \\
\text { marketing, criada por volta de } 1900 . \\
\text { Foco nas transações e vendas de } \\
\text { objetos. Autores: Copeland (1923); } \\
\text { Aspinwall (1958) }\end{array}$ & $\begin{array}{l}\text { ESCOLA CLÁSSICA } \\
\text { OU NEOCLÁSSICA }\end{array}$ \\
\hline Escola Funcional & $\begin{array}{l}\text { Criada no início de 1900, com foco } \\
\text { nas atividades necessárias para } \\
\text { executar as transações de marketing e } \\
\text { nos métodos de execução destas } \\
\text { transações. Autores: Shaw (1912); } \\
\text { Weld (1917); Vanderblue (1921); } \\
\text { Ryan (1935); Fullbrook (1940); } \\
\text { McGarry(1950) }\end{array}$ & $\begin{array}{l}\text { O período da } \\
\text { DESCOBERTA do } \\
\text { conceito de marketing }\end{array}$ \\
\hline Escola Institucional & $\begin{array}{l}\text { Criada por volta de 1910, atingindo o } \\
\text { auge no período de 1954 a 1973. Foco } \\
\text { na função de comercialização pelos } \\
\text { intermediários. Autores: Weld (1916); } \\
\text { Butler (1923); Breyer (1934); } \\
\text { Alderson (1954); McCammon (1963); } \\
\text { Balderston (1964); Bucklin (1965); } \\
\text { Mallen (1973). }\end{array}$ & $\begin{array}{l}\text { CONCEITUAÇÃO - } \\
\text { origem dos princípios de } \\
\text { marketing }\end{array}$ \\
\hline Escola Regional & $\begin{array}{l}\text { 1930. Foco nas transações entre } \\
\text { vendedores e consumidores de uma } \\
\text { dada região. Principais áreas } \\
\text { estudadas foram o varejo, mercado } \\
\text { atacadista e centros de atividades } \\
\text { econômicas das regiões: Autor: } \\
\text { Revzan (1961). }\end{array}$ & $\begin{array}{l}\text { DESENVOLVIMENTO } \\
\text { - especialização das áreas } \\
\text { de comercialização e } \\
\text { marketing }\end{array}$ \\
\hline
\end{tabular}




\begin{tabular}{|c|c|c|}
\hline Escola Funcionalista & $\begin{array}{l}\text { 1930. Compreende o marketing como } \\
\text { um sistema de estrutura inter- } \\
\text { relacionada e interdependente da } \\
\text { dinâmica de relacionamento. Autor: } \\
\text { Alderson (1945). }\end{array}$ & $\begin{array}{l}\text { Idem } \\
\text { DESENVOLVIMENTO }\end{array}$ \\
\hline Escola Administrativa & $\begin{array}{l}\text { Final dos anos } 40 \text { e início dos anos } 50 . \\
\text { Foco na determinação das } \\
\text { necessidades dos consumidores, no } \\
\text { marketing mix, na segmentação de } \\
\text { mercado, na miopia em marketing. } \\
\text { Autores: Borden (1950); Smith } \\
\text { (1956); McCarthy (1960); Levitt } \\
\text { (1960). }\end{array}$ & $\begin{array}{l}\text { REAVALIAÇÃO - } \\
\text { retomada dos conceitos } \\
\text { preliminares e adequação } \\
\text { às novas circunstâncias de } \\
\text { mercado }\end{array}$ \\
\hline $\begin{array}{l}\text { Escola Comportamento } \\
\text { do Consumidor }\end{array}$ & $\begin{array}{l}\text { Início da década de 50. Foco nos } \\
\text { mercados consumidores, nas } \\
\text { informações demográficas, sociais e } \\
\text { comportamentais dos consumidores. } \\
\text { Ênfase nos produtos de consumo, } \\
\text { finalizados e bens duráveis. Autores: } \\
\text { Katona (1953); Lazarsfeld (1955); } \\
\text { Festinger (1957). }\end{array}$ & $\begin{array}{l}\text { RECONCEITUAÇÃO- } \\
\text { conceitos preliminares } \\
\text { passaram a ser discutidos a } \\
\text { partir da ênfase na tomada } \\
\text { de decisão gerencial, nos } \\
\text { aspectos sociais do } \\
\text { marketing e nas análises } \\
\text { quantitativas de mercado. }\end{array}$ \\
\hline $\begin{array}{l}\text { Escola Dinâmica } \\
\text { Organizacional }\end{array}$ & $\begin{array}{l}\text { Final dos anos } 50 \text { e início dos anos } 60 . \\
\text { Foco no bem estar do consumidor e } \\
\text { necessidades dos membros dos canais } \\
\text { de distribuição, como os fabricantes, } \\
\text { atacadistas e varejistas. Autores: } \\
\text { Ridgeway (1957); Mallen (1963); } \\
\text { Stern (1969). }\end{array}$ & $\begin{array}{l}\text { Idem } \\
\text { RECONCEITUAÇÃO }\end{array}$ \\
\hline Escola Macromarketing & $\begin{array}{l}\text { Início dos anos 60. Foco nas } \\
\text { atividades de marketing e instituições } \\
\text { sociais. Surgiu como consequência do } \\
\text { crescente interesse da função dos } \\
\text { negócios na sociedade. Autores: } \\
\text { Holloway e Hancock (1964), Fisk } \\
\text { (1967); Shawer e Nickels (1979); } \\
\text { Hunt e Burnett (1982). }\end{array}$ & $\begin{array}{l}\text { DIFERENCIAÇÃO - } \\
\text { novos conceitos passam a } \\
\text { ser discutidos - marketing } \\
\text { societal, ambiental e } \\
\text { internacionalização dos } \\
\text { mercados. }\end{array}$ \\
\hline Escola Sistêmica & $\begin{array}{l}\text { Anos 60. Foco nas respostas às } \\
\text { mudanças do meio ambiente. Autores: } \\
\text { Boulding (1956); Forrester (1958); } \\
\text { Kuhn (1963); Bertalanffy (1968); } \\
\text { Howard (1983). }\end{array}$ & $\begin{array}{l}\text { Idem } \\
\text { DIFERENCIAÇÃO }\end{array}$ \\
\hline $\begin{array}{l}\text { Escola das Trocas } \\
\text { Sociais }\end{array}$ & $\begin{array}{l}\text { Surgiu em meados dos anos } 60 . \text { Foco } \\
\text { nas trocas entre vendedores e } \\
\text { consumidores e perspectiva interativa } \\
\text { com respeito às transações de } \\
\text { mercado. Autores: Maclnnes (1964); } \\
\text { Alderson e Martin (1965); Kotler } \\
\text { (1972); Bagozzi (1974); Houston e } \\
\text { Gassenheimer ( 1987). }\end{array}$ & $\begin{array}{l}\text { Idem } \\
\text { DIFERENCIAÇÃO }\end{array}$ \\
\hline
\end{tabular}




\begin{tabular}{|c|c|c|}
\hline Escola Ativista & $\begin{array}{l}\text { Surgiu por volta da década de } 70 . \\
\text { Foco no desequilíbrio da força entre } \\
\text { vendedores e consumidores, no mau } \\
\text { uso do marketing pelas firmas } \\
\text { individuais, e em assuntos do bem } \\
\text { estar e satisfação do consumidor. } \\
\text { Autores: Been (1973); Gardner } \\
\text { (1976); Russo (1976); Jacoby e Small } \\
\text { (1975); Preston (1976). }\end{array}$ & $\begin{array}{l}\text { SOCIALIZAÇÃO - as } \\
\text { questões sociais e as } \\
\text { influências sobre as } \\
\text { atividades de marketing }\end{array}$ \\
\hline $\begin{array}{l}\text { Marketing de } \\
\text { Relacionamento }\end{array}$ & $\begin{array}{l}\text { Anos 80. Foco na criação de lealdade } \\
\text { e na satisfação e retenção dos clientes. } \\
\text { Autores: Berry et al (1983); Jackson } \\
\text { (1985) e Spekman e Johnston (1986). }\end{array}$ & $\begin{array}{l}\text { Sem referência em } \\
\text { Bartels }\end{array}$ \\
\hline Cybermarketing & $\begin{array}{l}\text { Final da década de } 90 \text { e início de } \\
\text { 2000. Considerado um instrumento } \\
\text { facilitador de marketing, com foco na } \\
\text { possibilidade de trabalhar a } \\
\text { personalização em massa, } \\
\text { proporcionar rapidez no } \\
\text { processamento de transações e } \\
\text { permitir alta interatividade com os } \\
\text { clientes. Autores: Rowson (1998); } \\
\text { Rosembloom (1999); Poel e Leunis } \\
\text { (1999); Graham (2000) e } \\
\text { McCune(2000). }\end{array}$ & $\begin{array}{l}\text { Sem referência em } \\
\text { Bartels }\end{array}$ \\
\hline Marketing Experimental & $\begin{array}{l}\text { Final da década de } 90 \text { e início de } \\
2000 \text {. Foco nas sensações que os } \\
\text { produtos possam proporcionar aos } \\
\text { clientes e não meramente nas } \\
\text { necessidades dos consumidores. } \\
\text { Autor: Schmitt (1999) }\end{array}$ & $\begin{array}{l}\text { Sem referência em } \\
\text { Bartels }\end{array}$ \\
\hline
\end{tabular}

Tabela 1- Elaborada pelas autoras com base em Bartels (1976); Sheth et al (1988) e Miranda e Arruda (2004).

A análise das classificações da tabela acima, nos remetem às seguintes considerações: - Os autores divergem quanto à nomenclatura do período, talvez pela formação acadêmica e pelo momento histórico vivido pelos mesmos. Bartels foi professor de Marketing da Ohio State University e focou os seus estudos na conceituação da área a partir das escolas de pensamento. Sheth, também professor, dedicou-se desde a década de 1960 aos estudos sobre comportamento do consumidor, enfatizando, através da nomenclatura proposta, uma aproximação com o conceito de consumidor em cada período histórico.

- A classificação de Sheth se assemelha ao trabalho de Bartels, sendo esse autor referência para os seus estudos. Ele avançou na classificação até o início do século XXI, pois na atualidade ainda dirige um instituto sobre estudos avançados em comportamento do consumidor. Bartels faleceu na década de 1980. 
- Até o início da década de 1950, o foco da atividade estava restrito a processos e definições sobre pontos específicos da atividade de marketing relacionada a vendas e distribuição. Após essa data, a ênfase passou a ser no consumidor e na construção de relacionamentos com seus principais clientes. Na década de 60 , momento de grande convulsão social em várias áreas sociais e econômicas, a preocupação com os fatores éticos e sociais foram os pontos principais que caracterizaram a atividade.

- Analisando o quadro acima, dividimos o desenvolvimento das escolas de pensamento em duas etapas: de 1900 até 1970 - firmaram-se as fundamentações teóricas da área e, após essa década, no início da década de 1980, a área passou a ser influenciada pelas novas tecnologias e pela participação mais ativa do consumidor no mercado. Este se tornou mais crítico e participativo. No início do século XXI, as propostas para a atividade de marketing se tornaram mais diversificadas e surgiram novas nomenclaturas para área, segmentando a atividade em: marketing colaborativo, marketing digital, marketing de relacionamento, etc. $\mathrm{Na}$ atualidade, os profissionais de marketing podem estar vivenciando a formação de uma nova escola de pensamento, apoiada na visão do consumidor enquanto pessoa, com ênfase no aspecto psicológico.

[...] pode-se observar a preparação para o surgimento de uma nova escola do pensamento em marketing, com foco voltado não meramente para as interações mútuas entre vendedores e compradores, mas nos relacionamentos que envolvem sensações e experiências, abrangendo o aspecto psicológico do consumidor e que está marcando o início do século XXI [...] (Miranda \& Arruda, 2004, p. 54).

A partir dessa reconstrução histórica proposta por Bartels (1976) e Sheth (1988), serão apresentadas as principais características, autores e obras de cada período, bem como e as ideias sobre o conceito de consumidor extraídas desse contexto. A seguir, destacaremos o desenvolvimento da Psicologia do Consumidor através das atividades dos principais psicólogos que trabalharam e se dedicaram aos estudos sobre publicidade, consumo e comportamento do consumidor. 


\subsection{1 - Período anterior a 1900 - Escolas Clássica ou Neoclássica - 1900 a 1910 - Período da Descoberta/Escola de Commodity}

O período denominado como escolas clássica e neoclássica foi baseado nos princípios da ciência econômica. Destacaram-se os autores: Adam Smith (1723-1790), Robert Torrens (1780-1864), James Mill (1773-1836) e David Ricardo (1772-1823).

As relações comerciais consideravam basicamente dois fatores do processo econômico como sendo realmente importantes: a produção e a distribuição. A área de Marketing não se distinguia da área econômica. Os produtos eram padronizados - commodities, atendendo aos princípios da produção.

Simões (1976), entretanto, apontou para o que denominou uma "extraordinária antevisão" do economista clássico inglês R. Torrens, quando escreveu numa passagem em sua obra:

[...] Criam riqueza e utilidade, tanto quanto as atividades produtoras propriamente ditas, aquelas atividades destinadas a tornar as mercadorias disponíveis em momentos e lugares onde a demanda é maior do que no momento e lugar em que as mesmas foram produzidas [...] ( R. Torrens: The Economist Refuted citado por Simões,1976, p. 15).

Em outras palavras, conforme Simões (1976), Torrens lançou as bases para uma das definições modernas do marketing como sendo o processo que visa levar a mercadoria certa, ao consumidor certo, no lugar certo e no tempo certo.

Para Simões (1976), os economistas clássicos não reconheciam que a demanda deveria ser estimulada e criada, pois partiam do princípio de que a produção não atendia a totalidade da demanda, não existia concorrência, e tudo o que era produzido era consumido.

\subsection{2 - 1910 a 1920 - Conceituação/Escola Funcional}

No período da Conceituação surgiram os primeiros cursos de Marketing nos Estados Unidos: Universidade de Ohio (1904), Universidade da Pensilvânia (1905), Universidade de Pittsburgh (1909) e Universidade de Wisconsin (1910). Os professores que ministravam os cursos nas diferentes escolas eram: E. D. Jones, Simon Litman, George M. Fisk, W. E. Kreusi, H. S. Person e James E. Hagerty. Surgiram autores da área da psicologia e da 
publicidade que estudavam os efeitos da comunicação mercadológica sobre os consumidores tais como: W.D. $\operatorname{Scott}^{18}$, E. E. Calkings, R. Holden, G. H. Powell.

Sobre as primeiras escolas de negócios que ministraram aulas sobre marketing Gracioso (1973) destacou:

[...] Os estudos formais sobre comercialização foram surgindo. Em 1904, na Ohio State University, o Prof. Hagerty ditou o primeiro curso de marketing, versando problemas agrícolas, sob o título "A Distribuição das Safras". Em 1908, W. D. Scott publica The Psychology of Advertising e, cinco anos depois, H. L. Hollingworth lança Advertising and Selling. Copeland, de Harvard, em 1915, ministrou o primeiro curso sob o título "Comercialização". Em 1920, Cherrington publica Elementos de Comercialização e, em 1921, é a vez de Paul Ivy lançar os Princípios de Comercialização. Em 1924 Melvin Copeland edita Principles of Merchandising [...] (p. 6-7).

Ralph Starr Butler (1906, citado por Bartels, 1970, p. 13) articulou o conceito de marketing a "tudo aquilo que promove o produto deve ser prioridade dos homens de vendas e de propaganda". A ideia de marketing tinha, segundo diferentes autores, um significado coletivo, integrativo e de agregação. Essa abordagem precedeu as ideias sobre Administração de Marketing e Administração do Mix de Marketing ${ }^{19}$.

$\mathrm{O}$ momento da descoberta do conceito de marketing foi favorecido pelo avanço dos estudos de mercado. Os autores A. W. Shaw, Paul H. Nystrom, Paul T. Cherington, e C. S. Duncan, em 1920, passaram a estudar o Marketing como uma área científica, iniciando os trabalhos de pesquisa de marketing. Segundo Gracioso (1975, p. 17), Arch W. Shaw, em 1912, definiu que o estudo das atividades mercadológicas era "a aplicação do movimento à matéria." O seu conceito funcional considerava que, da mesma forma que a matéria, a função é indestrutível.

Aos poucos surgiu a necessidade de se desvendar as condições sociais e econômicas dos consumidores. Nesse momento, os princípios da escola clássica já não eram suficientes para explicar a relação entre aqueles que compravam e aqueles que vendiam. Crescia o

\footnotetext{
${ }^{18}$ Walter Dill Scott (1869-1955) foi um dos primeiros psicólogos a utilizar a psicologia aplicada na propaganda. Em 1909 foi nomeado professor de publicidade e psicologia da Escola de Comércio da Universidade de Northwestern, e em 1912, professor de psicologia aplicada na Escola de Comércio. Pouco depois de voltar da Alemanha, enquanto estava ensinando na Universidade de Northwestern, foi abordado por um executivo da publicidade procurando por ideias para tornar a publicidade mais eficaz. Ele voltou a sua atenção para essa área e publicou dois livros. Durante 1919-1920, foi presidente da Associação Americana de Psicologia (APA). Retirado do World Wide Web <http// http://www.onread.com/writer/Scott-Walter-Dill-6096/> em 16 de dezembro de 2012.

${ }^{19}$ Esses termos foram defendidos pelos pesquisadores da área de Marketing a partir da década de 1930, quando essa passou a integrar as decisões estratégicas das empresas.
} 
interesse sobre a propaganda dos produtos como consequência natural do incentivo e da promoção dos novos mercados.

As aproximações dos estudos da psicologia e da publicidade contribuíram para a tentativa de se entender o processo de motivação dos consumidores. Não existia um conceito específico de consumidor, mas um crescente interesse em desvendar suas características com base nos estudos de psicologia e publicidade.

\subsection{3 - 1920 a 1930 - Integração/ Escola Institucional}

Este período representou o momento de fundação da área de Marketing como disciplina e ciência. Os autores e obras que representaram essa etapa foram segundo Bartels (1906, citado por Bartels, 1970, p. 13): Paul T. Cherington (1920) - a obra "Os Elementos de Marketing”, de Frederick W. Taylor's (1919) - Modern Sales Management de James E. Hagerty (1913) - Mercantile Credit. O pensamento em marketing em seus primórdios descrevia as commodities, instituições e funções do marketing. Seus manuais eram especializados nos mercados agrícolas, antes focados nas questões operacionais. Nesse momento começavam a analisar o papel do vendedor nesse mercado, com a utilização de princípios da psicologia na prática publicitária, o que provocou um desenvolvimento da área (1906, citado por Bartels, 1970, p. 13).

Nesse período, cresceu o interesse pelo desenvolvimento da área de vendas como um fator importante para a abordagem do cliente além do interesse nas características do vendedor, assim como a forma como eles abordavam os consumidores.

$\mathrm{Na}$ literatura da época, o processo de vendas poderia ser ensinado e aprendido tendo como alvo principal ensinar ao vendedor como melhor abordar o consumidor. Os melhores vendedores eram aqueles que tinham boas qualidades como pessoas, interesse pelo produto, cortesia e inteligência (1906, citado por Bartels, 1970, p. 13).

\subsection{4 - 1930 a 1940 - Desenvolvimento/ Escola Funcionalista}

O período do desenvolvimento teve como principal característica a formalização do campo de estudo integrando os princípios de marketing. Essas articulações dos princípios de marketing apareceram nos textos de: A.W. Shaw, E.J. McCarthy e L.D.H. Weld. 
Otto Kleppner, em 1920, dedicou-se aos estudos sobre Marketing e Publicidade aproximando as áreas segundo um modelo, chamado pelo autor dos três estágios da publicidade - o produto como pioneiro, competitivo e conceituado. Já George B. Hotchkiss e Hugh E. Agnew refinaram o conceito, passando a adotar o mesmo como técnica para criação publicitária. Um produto para ganhar destaque, e ser realmente consumido pelo mercado, deveria ser comunicado de forma diferenciada. As características específicas como o preço competitivo e a marca conhecida, garantiam bons retornos dos investimentos em comunicação.

No ambiente acadêmico, não existia oficialmente a disciplina de Marketing. Seus estudos faziam parte das disciplinas de Economia e Publicidade, ministrados nos cursos superiores de Economia e Administração. Walter Scott, em 1915 criou a Nacional Association of Teachers of Advertising e se tornou o seu primeiro presidente e propôs, no ano de 1923 a um grupo de economistas [...] "profissionais de marketing que se juntassem a eles em sua próxima reunião, o que foi aceito. Assim, em 1926, nasceu a National Association of Teachers of Marketing and Advertising (NATMA)" [...] (Ajzental, 2010, p. 35).

A partir desses encontros entre profissionais acadêmicos, surgiu a primeira associação que congregava professores de universidades e profissionais de marketing - a American Marketing Society, no ano de 1930 e passaram a publicar, desde 1934 o periódico acadêmico American Marketing Journal. Posteriormente, a associação passou a se chamar American Marketing Association (AMA). O início dessa associação marcou o princípio da cronologia do Marketing enquanto disciplina e área de estudos.

Segundo os estudos da AMA e dos pesquisadores dessa época, as principais funções de marketing passaram a ser: comprar, vender, transportar, estocar, padronizar, financiar e prover o mercado de informação. Nesse contexto surgiram os estudos sobre canais de venda e distribuição associados às estratégias de mercado. Outro destaque dessa época é o surgimento do conceito dos 4P's - o composto de marketing que integra as variáveis de produto, preço, ponto de venda e promoção, popularizado pelo autor E.J. McCarthy, na década de 1940. Na literatura acadêmica da área de Marketing, McCarthy aparece como o autor desse conceito, porém [...] "esses são, na realidade, derivados das classificações anteriormente apresentadas pelos teóricos da Escola Funcional, como Shaw, Weld, Ryan e McGarry” [...] (Ajzental, 2010, p. 35).

No ano de 1935 o conceito de marketing da AMA era "O marketing, num sentido amplo, cobre as atividades de negócios que dizem respeito à criação da utilidade de lugar e tempo" (AMA, 1935, citado por Keefe, 2004 e Ajzental, 2010, p. 241). Outros conceitos 
surgiram e completaram as novas abordagens da área: as ideias sobre conveniência, compras e classes especiais de consumidores de produtos estavam atreladas aos princípios de mercado, e o autor Melvin C. Copeland reforçou a ideia de "conveniência, necessidade e compra de produtos", proposta por C.C. Parlim, no ano de 1912. As principais funções de marketing passaram a ser: comprar, vender, transportar, estocar, padronizar, financiar e prover o mercado de informação. Nesse contexto, surgiram os estudos sobre canais de venda e distribuição associados às estratégias de mercado.

Especificamente sobre o conceito de consumidor, percebeu-se a necessidade de atender melhor a demanda do mercado que, em função dos períodos de recessão (resultado das guerras), não tinha crédito para consumir os produtos. Começava a surgir a preocupação de adequar a oferta aos consumidores com a melhoria nas formas de pagamento, promoções, etc.

\subsection{5 - 1940 a 1950 - Reavaliação/ Escola Administrativa}

O período da reavaliação teve como principais representantes os autores: H.E. Agnew, R. B. Jenkins e J. D. Drury (1936, citado por Bartels, 1970), além de C. W. Barker e N. Anshen (1939, citados por Bartels, 1970) que elaboraram artigos sobre o desenvolvimento da comercialização dos produtos.

Nessa década, o pensamento em marketing assumiu um caráter significativo, mas enfrentou problemas e influências da depressão econômica (resultado das guerras), da expansão da população urbana, além do estímulo a poupança e a baixa autoestima da população. Nesse contexto surgiram os movimentos de consumidores questionando os apelos ao consumo, bem como os preços praticados. A resposta do mercado foi criar o termo "crédito ao consumidor", de modo a estimular a economia e os mercados.

No campo da publicidade, as descobertas das abordagens psicológicas, os estudos dos meios e o avanço da tecnologia, proporcionaram bons resultados para a propaganda dos produtos. Os estudos sobre os efeitos sociais da publicidade apontaram para os usos e abusos da área. Começou a surgir um consumidor mais crítico e capaz de questionar o valor dos produtos e a forma como eram divulgados. Essa atitude era, em parte, consequência do problema financeiro que os Estados Unidos enfrentaram e resultado das Grandes Guerras. 


\subsection{6 - 1950 a 1960 - Reconceituação/ Escola do Comportamento do consumidor}

O período da reconceituação teve como principais representantes: Ralph S. Alexander, F. M. Surface, R. F. Elder e Wroe Alderson (1940). A principal característica dessa época era de que o conceito de marketing deveria ser reavaliado.

Essa etapa não foi classificada como uma época de grande desenvolvimento e avanços dos estudos de marketing, produtos da guerra, a qual interrompeu muitas atividades industriais e acadêmicas. Destaque para a realização de conferências e a criação de informativos: Journal of Retailing e Journal of Marketing.

A reavaliação do conceito passou por uma crítica dos acadêmicos que questionavam a essência da teoria do pensamento e, os modos como o Marketing poderia atender a significados mais amplos quanto as suas funções e especializações.

Essa necessidade de mudança apareceu em textos publicados em artigos por diferentes profissionais conforme citou Bartels (1970 p. 51-52):

\section{RELAÇÃO DE TEXTOS PUBLICADOS}

Bartels, Robert. “Marketing Principles”, Journal of Marketing, Vol. IX, No. 4 (October, 1944), p. 151.

Converse, P. D. "The Development of the Science of Marketing: An Exploratory Survey", Journal of Marketing, Vol. X, No. 3 (July, 1945), pp. 14-32.

Bartels, Robert, "Marketing Theory: Its Essential Nature", em Proceedings of the Christmas Meetings of the American Marketing Association, 1946.

Brown, Lyndon O. "Toward a Profession of Marketing “, Journal of Marketing, Vol.XIII, No. 3 (July, 1948), p. 27.

Vaile, R. S. "Towards a Theory of Marketing: A Comment", Journal of Marketing, Vol. XIII, No. 2 (April, 1946), p. 520.

Bartels, Robert. "Can Marketing Be a Science?" Journal of Marketing. Vol. XV, No. 1 (January, 1951), p. 319.

Bartels, Robert. "Influences on the Development of Marketing Thought", Journal of Marketing, Vol. XVI, No. 3 (July, 1951), p. 1.

Mc Garry, E. D. "The Contractual Function in Marketing “, Journal of Marketing, Vol. XIV, no. 2 (April, 1951), p. 96.

Wales, Hugh G. (ed.), “Changing perspectives in Marketing”, University of Illinois Press, Urbana, 1951.

Hagerty, James E. "Experiences of Our Early Marketing Teachers", Journal of Marketing, Vol. 1, no. 3 (July, 1936), p. 20.

Maynard, H. H. "Training Teachers of Marketing and Research Workers", Journal of Marketing, vol. II, no. 2 (April, 1938), p. 282.

Agnew, H. E. "The History of the American Marketing Association", Journal of Marketing, Vol. V, no. 2 (April, 1941), p. 374.

Maynard, H. H. "Marketing Courses Prior to 1910", Journal of Marketing, Vol. V, No. 2 (April,1984), p. 382.

Maynard, H. H. "Early Teachers of Marketing", Journal of Marketing. Vol. VII, No. 4 (October, 1942), p. 158. 
Converse, P. D. “ Fred Clark's Bibliography as of the Early 1920's" , Journal of Marketing, vol. X, no. 3 ( July , 1945), p. 54.

Converse, P. D. “ Fred Clark's Bibliography as of the Early 1920's" , Journal of Marketing, vol X, no. 3 (July, 1945), p. 54.

Litman, Simon. "The Beginnings of Teaching Marketing in American Universities", Journal of Marketing, vol XV, No. 4 (October, 1950), p. 220.

Bartels, Robert, "Influences on the Development of Marketing Thought", Journal of Marketing, vol. XVI, no. 3 (July, 1951), p1. ${ }^{20}$

Tabela 2- Elaborada pelas autoras com base em Bartels (1970).

$\mathrm{O}$ conceito de consumidor permaneceu atrelado às ideias de mercado, e a atenção às necessidades dos consumidores ainda não era uma prioridade dos pesquisadores. Entretanto, começavam a surgir ideias sobre comportamento do consumidor atrelado às práticas de mercado, sob a influência de outras áreas das Ciências Sociais, como a Psicologia. Nesse contexto, Shaw e Jones (2005, p. 26, tradução nossa) apontaram:

[...] Antes de 1950, havia numerosos psicólogos, psicólogos sociais, sociólogos e economistas, cujos trabalhos influenciaram o desenvolvimento precoce do comportamento do consumidor no pensamento de marketing. Sheth et al. (1988) menciona esses nomes bem conhecidos como Maslow, Festinger, Homans, Rodgers, Osgood, Simon, Katona, Katz e Lazerfield, entre muitos outros. Em torno de 1950, os pesquisadores da motivação em marketing, como Ernest Dichter, seguiram a tendência freudiana. [...] Embora levando a alguns métodos psicológicos que foram úteis, como as entrevistas em profundidade, técnicas projetivas, e grupos focais, conceitualmente este tipo de pesquisa em grande parte, se transformaram em uma espécie de "beco sem saída", e a maioria dos estudiosos subsequentes preferiram esquecer a ênfase inicial na motivação subconsciente [...].

Essa aproximação com as abordagens da psicologia, que permeavam os estudos sobre o comportamento humano na década de 1950, foram fundamentais e decisivas para o entendimento do real significado do consumidor e suas relações com o mercado, as quais seriam mais aprofundadas nas décadas seguintes.

\subsection{7 - 1960 a 1970 - Diferenciação/ Escola Dinâmica Organizacional}

No período da Diferenciação ocorreu a principal mudança de paradigma. Ajzental (2010) afirmou que a partir da década de 1950 surgiram as Escolas do Comportamento do Consumidor e Gerencial, provocando mudanças profundas na forma de conceber e conceituar o pensamento em marketing. Na década de 1950, March, Simon (1958, citados por Ajzental,

\footnotetext{
${ }^{20}$ Bartels, 1970.
} 
2010), assim como Edwards (1961, citado por Ajzental, 2010) pesquisadores com formação na área da Psicologia Cognitiva ${ }^{21}$, contribuíram para o esclarecimento de conceitos que causavam conflitos organizacionais. Entre esses conceitos estavam: utilidade objetiva, racionalidade limitada, objetivos e metas para a satisfação de conflitos organizacionais resultantes de diferenças no que se referia à percepção e às metas entre os empregados das corporações. A presença do elemento humano como força propulsora do desenvolvimento das organizações passou a ser considerado como elemento vital para o crescimento das empresas e, nesse sentido, o campo da psicologia contribuiu com a melhoria das interpretações dos relacionamentos humanos nas empresas.

Entre outros estudos, destacaram-se nessa época: as pesquisas sobre motivação que foram incrementadas a partir das pesquisas inéditas sobre opinião, liderança, fidelidade à marca e segmentação demográfica, com a aplicação de técnicas de modelagem econométrica ${ }^{22}$ para medir o impacto de diversas variáveis individuais sobre o comportamento de compra. Por outro lado, também foram estudadas as atitudes, os estilos de vida e as experiências psicológicas em laboratório para determinar o comportamento de compra (Ajzental, 2010, p.125).

Os autores que contribuíram de forma direta para o fortalecimento dessa escola foram: Maslow (1954), Festinger (1957), March e Simon (1958), Heider (1958), McGregor (1960), Edwards( 1961), Allport (1961), Homans ( 1961), Mc Clelland ( 1961), Sheth (1967). Robert Holloway e seus alunos da Universidade de Minnesota utilizaram a aplicação da teoria da dissonância cognitiva ${ }^{23}$ para estudar o comportamento de escolha das marcas, conforme Ajzental (2010, p. 125).

Raimon Bauer, na Universidade de Harvard, propôs a teoria do risco percebido que utilizava basicamente a teoria dos conceitos da racionalidade limitada e da satisfação no

\footnotetext{
${ }^{21}$ A psicologia cognitiva moderna ou processamento de informação surgiu na década de 50 do século XX e pode ser considerado um novo "paradigma". [...] Se insere num movimento que alguns chamam de "revolução cognitiva". Seu surgimento coincide com a fundação de uma nova ciência da mente, interdisciplinar, composta por disciplinas tão diversas quanto a Filosofia, as Ciências da Computação, a Psicologia, da qual estamos falando. Esse surgimento concomitante da psicologia cognitiva e das ciências cognitivas fez com que a psicologia cognitiva nascesse não meramente como um novo sistema psicológico, com objetivos bastante diferentes do behaviorismo praticado até aquele momento. (Lopes, Lopes \& Teixeira, 2004).

${ }^{22}$ Trata-se da análise financeira feita por meio de índices calculados a partir das demonstrações financeiras. Esse modelo surgiu da necessidade prática de avaliar o quão saudável financeiramente uma empresa está, auxiliando investidores, credores e administradores na predição de situações favoráveis ou dificuldades financeiras (Scarpel \& Milioni, 2001).

${ }^{23}$ A Teoria da Dissonância Cognitiva, formulada por Festinger, parte do pressuposto de que o ser humano, mediante um processo individual de auto-avaliação, configura sua própria auto-imagem (self-concept), utilizando-a como parâmetro ou padrão referencial de medida na sua auto-apreciação e também na comparação com características que faz das outras pessoas com características individuais que considera como equivalentes às próprias. Quando percebe que existem incongruências ou discordâncias entre ambas avaliações, surge o fenômeno psicológico conhecido como "dissonância cognitiva"que, em geral, se traduz por um estado de stress, mais ou menos intenso, que leva o indivíduo a desenvolver comportamentos dirigidos a superá-lo, para assim restituir a suposta condição original de "consonância"ou equilíbrio psicológico (Keef, 1988).
} 
comportamento do consumidor. Sobre essa passagem histórica, Ajzental (2010, p. 125), afirmou:

Uma terceira linha de pesquisa, iniciada na Universidade de Harvard, sob a liderança de Raimond Bauer, propunha a teoria do risco percebido no comportamento do consumidor. Essa teoria utilizava basicamente a teoria dos conceitos da racionalidade limitada e da satisfação. Uma quarta linha focalizava as teorias de compreensão e desenvolvimento do comportamento do consumidor, nas quais aceitava que o comportamento do consumidor era muito complexo e altamente dinâmico para que pudesse ser totalmente explicado por modelos unidimensionais ou cross-sectional.

Segundo Blackwell, Miniard e Engel (2005), James Engel, David Kollat e Roger Blackwell lançaram em 1968 o modelo integrado de comportamento do consumidor. Nesse modelo o "consumidor era visto como um indivíduo racional, que baseava suas escolhas em um grande número de variáveis e uma interação complexa entre crescimento, atitude, intenção e comportamento." Esses autores trouxeram uma proposta mais centrada no conhecimento do comportamento dos consumidores usados nos processos gerenciais. O modelo PDC (Processo de Decisão do Consumidor) em sua forma inicial e ficou conhecido como EKB (sigla dos nomes Engel, Kollat e Blackwell). Posteriormente, o mesmo modelo evoluiu e foi renomeado com a sigla EBM, incorporando o nome do professor Paul Miniard, que se juntou à equipe.

Como demonstra o modelo, os consumidores normalmente passam por sete estágios maiores de tomada de decisão: reconhecimento da necessidade, busca de informações, avaliação de alternativas pré-compra, compra, consumo, avaliação pós-consumo e descarte. Apesar de os livros-texto de marketing e os pesquisadores de consumo empregarem terminologia um pouco diferente para cada um dos estágios, o estudo do comportamento do consumidor está focado primariamente nesses sete estágios e como vários fatores influenciam cada estágio de decisão dos consumidores. Compreendendo os estágios dentro do mapa de tomada de decisões do consumidor, profissionais de marketing podem descobrir por que as pessoas compram, ou não, produtos e o que fazer para que essas pessoas comprem mais de um fornecedor específico (Blackwell, Miniard e Engel, 2005, p. 73). 


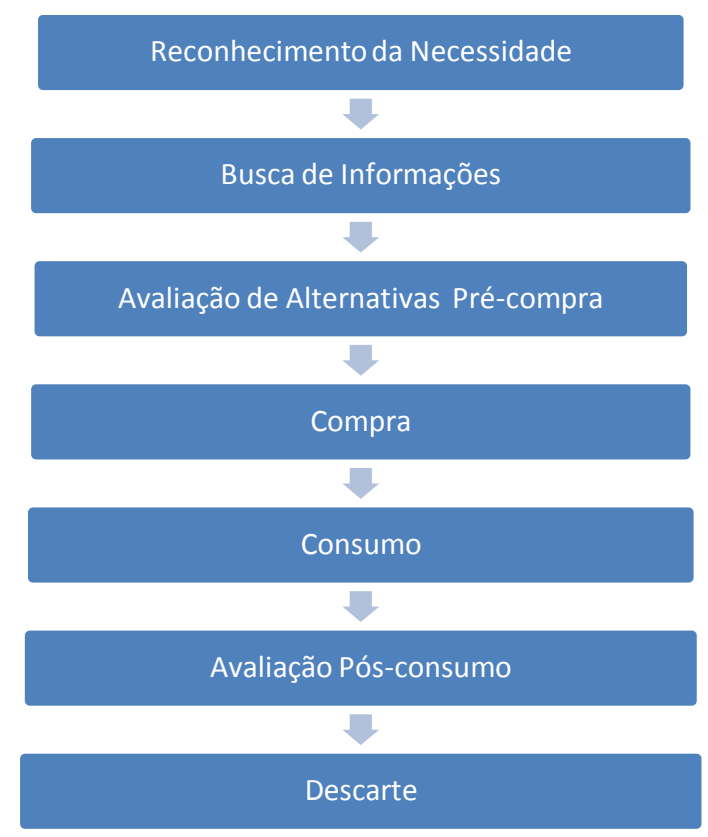

Figura 1 - Como os consumidores tomam decisões para bens e serviços. Elaborado pelas autoras com base em Blackwell, Miniard e Engel (2005, p. 73).

Em 1970 surgiu a Association for Consumer Research (ACR). Os fundadores eram provenientes de diferentes áreas: Marketing, Psicologia, Economia Doméstica, Sociologia, Economia Agrícola, entre outras. Os profissionais que participaram dessa associação eram jovens e se destacaram pelo interesse crescente na disciplina de Psicologia, com o objetivo de explorar a pesquisa em marketing mais sobre os aspectos do comportamento do consumidor do que pelas variáveis econômicas e de mercado.

A Escola do Comportamento do Consumidor, gerencial e sistêmica foi destaque no período de 1950 a 1980. Para Ajzental (2010, p. 211) - duas perspectivas emergiram como domínio principal de marketing: (1) a visão gerencial e (2) a ciência comportamental e quantitativa "como chaves para o desenvolvimento do conhecimento futuro". Cresceu, assim, a importância da visão gerencial para as empresas e o surgimento da ciência comportamental como área de pesquisa e estudos para o marketing.

Em 1974 foi lançado o Journal of the Consumer Research, fortalecendo a área de comportamento do consumidor com o crescimento da publicação de artigos científicos sobre esse tema. Entre as revistas mais citadas no Journal of Marketing Research entre 1966 e 1970 estavam, sobretudo, as voltadas para as Ciências Sociais ( Public Opinion Quartely, Journal of Abnormal and Social Psychology, Psychological Bulletin); e para a área de gestão (Journal of Marketing, Journal of Business, Harvard Business Review, etc.). Entre elas se destacava também a revista Management Science. 
Com o fortalecimento dos estudos sobre comportamento do consumidor, esse passou a ser o centro principal dos estudos das disciplinas de Marketing Management e Marketing Concept. Esse direcionamento abriu espaço para a ampliação das pesquisas na área do comportamento do consumidor, tanto sobre as práticas de consumo para melhorar as vendas e o lucro, como uma perspectiva coletiva (colocar-se a serviço do consumidor). Essa perspectiva de estudo era chamada de consumer research.

$\mathrm{O}$ foco deixou de ser o mercado de consumidores e passou-se a analisar de forma mais individual o comportamento dos mesmos, surgindo o conceito de segmentos de consumidores.

A disciplina de Marketing, nas escolas, passou a focar no comportamento do consumidor. Isso evidenciou um momento de ampliação do conceito de consumidor como ponto central da atividade mercadológica.

\subsection{8 - 1970 a 1980 - Socialização/Escola Ativista/ 1980 - Marketing de Relacionamento} - 1990 - Cybermarketing/ 1990 - 2000 - Marketing Experimental

As concepções modernas do Marketing, a partir desse período, apontaram para o Marketing Social, Orientação para o Mercado, Marketing de Serviços, Marketing de Relacionamento, Gestão de Valor da Cadeia de Suprimentos e Gestão de Recursos.

Os autores que contribuíram para o desenvolvimento desse período foram: Kassarjian e Robertson (1981), Holbrook (1985), Engel, Black e Miniard (1997), Keith (1960), Kotler (1967), Markin (1969), Peters e Waterman ( 1982), Sheth (1985) e Lele e Sheth (1987).

Simões (1976) analisou em sua obra a evolução da teoria de marketing em relação aos estágios do desenvolvimento econômico, a partir da obra de Walt Rostow (1960), que na época era professor de História Econômica no Massachusets Institutte of Technology.

Nos cinco estágios definidos por esse autor, analisados a partir das sociedades tradicionais primitivas, até o chamado Estágio do Pós-Consumo, essa abordagem chamou a atenção pela contemporaneidade da análise. Walt Rostow classificou tal etapa do desenvolvimento econômico como a fase da pós-maturidade econômica. Já Simões (1976) relacionou esse momento com a evolução da teoria de marketing, como sendo a fase em que essa chegou ao ponto de conferir importância quanto ao comportamento do consumidor no processo de escolha e compra dos produtos.

Sobre essa fase, Simões (1976, p. 25) afirmou: 
A massa da população já tem uma renda discricionária suficiente para satisfazer muitos anseios e necessidades - os quais, por seu turno, são constantemente estimulados e aumentados, com o auxílio dos modernos meios de comunicação, que apressam o trânsito das novas ideias e ajudam a derrubar mais rapidamente as velhas barreiras e preconceitos. Neste estágio, ganha sua integral significação a frase famosa que define a filosofia do marketing: O Consumidor é Rei. O grande problema do homem de marketing consiste agora em adivinhar e satisfazer (antes que outros o façam) os mais recônditos desejos de Sua Majestade, o Consumidor. E, naturalmente, em estimular continuamente o surgimento de novos desejos. A filosofia empresarial também sofre o impacto desta nova ordem. A empresa passa a orientar-se em função das oportunidades atuais e potenciais do mercado e isto pressupõe o conhecimento cada vez mais perfeito das leis econômicas, sociais e psíquicas que regulam o comportamento do consumidor $[\ldots]$.

Gérard (1973, p.13) sinalizou para a importância de se considerar os fatores humanos na tomada de decisões estratégicas do homem de marketing:

O sistemático recurso aos procedimentos técnicos, às medidas, às estatísticas, não dispensam absolutamente, muito ao contrário, os especialistas do marketing de conceber a mais alta consideração aos fatores humanos incapazes de serem expressos em números. Estes elementos conservam uma importância quase sempre decisiva numa atividade comandada pelo homem e dirigida ao homem. [...] Essa é a razão pela qual um bom especialista em marketing procura sempre o movimento psicológico que se acha por trás dos números, que nunca fixam, conforme sabe, senão uma fase desse movimento [...].

Kotler (citado por Ajzental, 2010, p. 148) destacou que a prática do conceito de marketing orientado aos consumidores era necessária para a intersecção entre as ações dos negócios e os interesses dos consumidores. Sugeriu que a satisfação do consumidor não era suficiente para criar uma situação "ganha-ganha" entre consumidores e produtores por duas razões:

É muito difícil definir objetivamente a satisfação do consumidor; aquilo que é desejado pelo consumidor pode não ser efetivamente bom para ele. Assim, provê um paradigma para classificar todas as ofertas correntes baseadas em duas dimensões de satisfação: imediata; de bem estar do consumidor de longo prazo $[\ldots]$.

Ajzental (2010, p. 141), nomeou esse período como sendo do domínio da Escola Ativista $^{24}$. Os profissionais de marketing fortaleceram o conceito de marketing social e de

\footnotetext{
${ }^{24}$ Para Ajzental (2010 p. 141), a Escola Ativista representa tanto pesquisas empíricas quanto o pensamento conceitual relacionado a questões do bem-estar e da satisfação do consumidor. Mais especificamente, foca na falta de equilíbrio de poder entre os compradores e os vendedores e nas práticas ruins de Marketing pelas empresas que atuam de forma individual no mercado.
} 
marketing societal, permitindo oferecer o lado "bom" do papel do marketing. Para Ikeda, Campomar e Mendonça (1997), o objetivo principal do marketing social é "promover a mudança social e para isso serve-se principalmente de campanhas sociais". Para esses mesmos autores, as campanhas sociais são promovidas pela empresa para divulgar mudanças na saúde (combate ao fumo, álcool e drogas), ambientais (combate à poluição da água, do ar e preservação de florestas e animais em extinção), educação (combate ao analfabetismo e à evasão escolar, entre outros), e econômico (combate à cultura inflacionária e ao desperdício de recursos).

A era do Cybermarketing surgiu a partir da grande revolução da tecnologia digital dos anos 90 e início de 2000. As ideias de comunicação e estratégia em massa foram suplantadas pela possibilidade de individualização, da comunicação one-to-one, da busca pela personalização em massa. Além da possibilidade de rapidez na comunicação e abordagem de marketing, a tecnologia virtual proporcionou aos estrategistas de marketing uma ferramenta de precisão em dados estatísticos e recall. A possibilidade de interatividade favoreceu o surgimento de campanhas online e o envolvimento dos consumidores em múltiplas plataformas. O acesso à rede via computador também foi disponibilizado para os consumidores em meados do século XXI, tanto pelos smartphones como pelos tablets. O uso da tecnologia mobile favorece a comunicação e a abordagem dos consumidores de forma integrada e em tempo real.

Paralelamente à grande onda tecnológica, a ideia de Marketing Experimental surgiu como um contraponto: antes a tecnologia aprisionava o consumidor nos novos formatos de mídia e o impossibilitava de "reagir", tornava-o passivo diante das mensagens publicitárias e estratégias mercadológicas. No século XXI, a nova tecnologia digital ofereceu uma possibilidade a mais de interação e de participação. Algumas empresas lançaram campanhas e produtos com a coparticipação de seus consumidores, utilizando para esse processo o ambiente virtual.

As redes sociais, presentes no dia a dia dos consumidores, também propiciam essa interação. Mas, ao mesmo tempo em que o uso das redes e da internet aproxima as pessoas, também afasta, no sentido de que o consumidor fica cada vez mais solitário em suas decisões.

A tecnologia digital ofereceu aos profissionais das ciências do comportamento um suporte importante e necessário para a tomada de decisões, mas configura-se num modelo de afastamento do contato direto do consumidor com o mercado. O comércio online é cada vez mais uma realidade, configurando-se numa prática mercadológica que deverá crescer nos próximos anos. 
O consumidor da era digital é participativo, interativo e crítico, mas perdeu, num certo sentido, o contato físico com o mercado e, em alguns casos, passou a adquirir produtos e serviços de forma virtual. As novas tendências do marketing e das ciências do consumidor buscam revitalizar o valor da experiência de consumo, como uma ferramenta estratégica buscando uma melhor aproximação com o consumidor.

Quadro - Resumo da evolução do conceito de consumidor a partir da história do pensamento em marketing

\begin{tabular}{|c|c|}
\hline PERÍODO & O CONCEITO DE CONSUMIDOR \\
\hline $1910-1920$ & $\begin{array}{l}\text { Conceituação - Aproximações dos estudos da } \\
\text { psicologia e da publicidade contribuíram para a } \\
\text { interpretação da motivação dos consumidores. Não } \\
\text { existia um conceito específico de consumidor, mas, } \\
\text { um crescente interesse em desvendar suas } \\
\text { características baseado nos estudos de psicologia e } \\
\text { publicidade da época. }\end{array}$ \\
\hline $1920-1930$ & $\begin{array}{l}\text { Integração - Cresce o interesse nas características } \\
\text { do vendedor e na forma como eles abordam os } \\
\text { clientes. Na literatura da época, o processo de } \\
\text { vendas poderia ser ensinado e aprendido e tinha } \\
\text { como alvo principal ensinar o vendedor como } \\
\text { melhor abordar o consumidor. Os melhores } \\
\text { vendedores eram aqueles que tinham boas } \\
\text { qualidades como pessoas, interesse pelo produto, } \\
\text { cortesia e inteligência. }\end{array}$ \\
\hline $1930-1940$ & $\begin{array}{l}\text { Desenvolvimento - O interesse nos estudos sobre o } \\
\text { crédito, resultado dos períodos de depressão } \\
\text { econômica, demonstra uma preocupação em como } \\
\text { adequar a oferta aos consumidores. Melhoria nas } \\
\text { formas de pagamento, promoções etc. }\end{array}$ \\
\hline $1940-1950$ & $\begin{array}{l}\text { Reavaliação - Começa a surgir um consumidor } \\
\text { mais crítico e capaz de questionar o valor dos } \\
\text { produtos e a forma como são divulgados. Como } \\
\text { resultado do problema financeiro que os Estados } \\
\text { Unidos enfrentaram e das Grandes Guerras. }\end{array}$ \\
\hline $1950 / 1960 / 1970$ & $\begin{array}{l}\text { Reconceituação - O consumidor passa a ser } \\
\text { analisado e estudado a partir da ciência } \\
\text { comportamental. O foco deixa de ser a análise dos } \\
\text { mercados de consumidores e passa-se a analisar de } \\
\text { forma mais específica o comportamento dos } \\
\text { consumidores - surge o conceito de segmentos de } \\
\text { consumidores. A disciplina de Marketing nas } \\
\text { escolas passa a focar no comportamento do } \\
\text { consumidor, surgindo conceitos como: risco } \\
\text { percebido, processo de informação, influência do } \\
\text { grupo de referência, classe social, envolvimento, } \\
\text { psicográfica, de atitudes e influências situacionais. }\end{array}$ \\
\hline
\end{tabular}




\begin{tabular}{|c|c|}
\hline 1980 & $\begin{array}{l}\text { Diferenciação/Socialização - Os questionamentos } \\
\text { sobre os problemas do consumismo tomam conta da } \\
\text { sociedade. A abordagem do conceito de consumidor } \\
\text { se expande - o consumidor passa a ser } \\
\text { coparticipante dos lançamentos e dos produtos. As } \\
\text { novas tecnologias (internet) permitem novos } \\
\text { questionamentos e uma contínua participação do } \\
\text { consumidor no processo de compra e venda. }\end{array}$ \\
\hline $1990-2000$ & $\begin{array}{l}\text { Era do consumidor digital - o consumidor se torna } \\
\text { mais crítico, participativo e interativo. As redes } \\
\text { sociais configuram um cenário de troca de } \\
\text { informações. Entretanto, o consumidor está cada } \\
\text { vez mais solitário em suas decisões de compra. O } \\
\text { contato com os consumidores é retomado através do } \\
\text { advento das experiências de consumo, chamado de } \\
\text { marketing experimental }\end{array}$ \\
\hline
\end{tabular}

Tabela3 - Elaborado pelas autoras a partir do estudo das fontes e obras de referência. 


\section{3 - PSICOLOGIA, MARKETING E O CONCEITO DE CONSUMIDOR NUMA PERSPECTIVA HISTÓRICA.}

\section{1 - O desenvolvimento da psicologia científica e da psicologia do consumidor nos Estados Unidos.}

Entre os primeiros pesquisadores da psicologia norte-americana destacaram-se William James (1842-1910), na Universidade de Harvard, e John Dewey (1859-1952), nas universidades de Michigan, Minnesota e Chicago, através das obras Psychology, (1886) de Dewey, e Principles of Psychology (1890), de James. O livro de James foi considerado, segundo Ferreira e Gultman (2011, p. 124), como o "primeiro esboço do movimento funcionalista".

William James (1890, citado por Bueno, 2002, p. 83), na introdução da obra Princípios de Psicologia afirmava que a Psicologia era a "ciência da vida mental". A consciência como princípio da análise psicológica era tomada como "fenômeno psicológico de nível superior", que influenciava os "processos fisiológicos de nível inferior”. As questões biológicas do corpo e os fenômenos psicológicos da mente se interrelacionavam.

Essa concepção, para Bueno (2002, p. 83), "nega o reducionismo físiológico e valoriza os processos mentais ativos na relação com o ambiente". W. James inaugurou na psicologia uma preocupação que se manteve nos estudos psicológicos das gerações seguintes, conforme explica Bueno (2002, p. 83):

[...] quando se pensa que a mente é algo diferente da matéria, fica o problema cartesiano de explicar a interação entre estes dois mundos. Se, se nega a existência de uma mente separada e se reconhece apenas um cérebro físico com seus neurônios, está-se negando a experiência subjetiva que se tem. Mas, quando se aceita, como W. James, a experiência subjetiva e ao mesmo tempo o cérebro físico, tem-se que superar o "abismo entre os mundos interno e externo".

Na universidade de Cornell, Edward B. Titchener (1867-1927), representante do estruturalismo, e William James (1842-1910), na universidade de Harvard, representante do funcionalismo, trabalhavam nas pesquisas e formação dos psicólogos americanos e, "apesar das propostas de ambos serem conceitualmente diferentes, elas se aproximavam em um aspecto: consideravam a consciência como o objeto de estudo da psicologia". (Cançado, Soares e Cirino, 2011, p. 179).

Wundt, assim como James e Titchener, acreditava que a psicologia deveria, primeiramente, evoluir como ciência pura, sem ignorar o fenômeno mental, para depois ser 
usada para responder às questões do dia a dia de uma forma aplicada (Kuna, 1976, citado por Haugtvedt et. al, 2007, p. 4). Entretanto, esse pensamento não era compartilhado por todos os pesquisadores. Nesse mesmo período, William James (1842-1910) inaugurou o laboratório experimental na Universidade de Harvard e ofereceu a Hugo Münsterberg (1863-1916) a direção desse centro, que se tornou a "primeira voz" importante da psicologia aplicada nos Estados Unidos.

Outros estudantes que se formaram com Wundt, na Alemanha, adeptos dos estudos que envolviam os processos mentais, na busca por uma atividade voltada às questões do dia a dia das pessoas, focaram seus estudos na área da publicidade, entre eles: Edward Wheeler Scripture (1864-1943), na Universidade de Yale, Harlow Gale (1862-1945), na Universidade de Minnesota e Walter Dill Scott (1869-1955) na Universidade de Northwestern. Posteriormente, seguindo a tradição de Scott, Daniel Starch (1883-1979) prosseguiu com esses estudos.

$\mathrm{Na}$ Universidade de Columbia, surgiu um grupo de pesquisadores liderados por James McKeen Cattell (1860-1944) que, depois de voltar da temporada de estudos na Alemanha, recebeu novos alunos nessa universidade (aproximadamente no ano de 1900), com o interesse em estudar a psicologia aplicada. Para atender a esses alunos e ao interesse crescente em abrir novas áreas de pesquisa, recrutou um grupo notável de professores: Robert Sessions Woodworth (1869-1962), Edward Lee Thorndike (1874-1949), Harry Levi Hollingworth (1880-1956), Edward Kellogg Strong Jr. (1884-1943), e Albert T. Poffenberger (1885-1977).

Esses pesquisadores, apesar de terem se formado segundo a escola mentalista, tradicional nas universidades da época, partiram para uma abordagem relacionada ao controle do comportamento, influenciados pelo behaviorismo, que começava a despontar no ambiente acadêmico, com "foco nos estímulos complexos em oposição aos estímulos discretos" (Haugtvedt et. al, 2007, p. 20).

O movimento behaviorista foi inaugurado pelo psicólogo americano John B. Watson (1878-1958), através da publicação do artigo "Psicologia: como os behavioristas a veem" ${ }^{25}$. Watson apresentou uma proposta de psicologia científica que, segundo Bueno (2002, p. 84) “ignorava o fenômeno mental, incluído o da consciência, como objeto de estudo científico". Watson postulava o comportamento como objeto de estudo da psicologia e propunha que as

\footnotetext{
${ }^{25} \mathrm{O}$ título original do artigo era Psychology as the behaviorist views it, publicado em Psychological Review (1913), 20(2). Esse artigo está em domínio público e foi usada a tradução de Flávio Karpinskcki Gerab, Luis Eduardo de Vasconcelos Moreira, Mariana Zago Castelli, Pedro Eduardo Silva Ambra e Tauane Paula Gehn (Universidade de São Paulo), além de Marcos Bentes de Carvalho Neto (Universidade Federal do Paraná). Temas em Psicologia - 2008, 16 (2), 289-301.
} 
análises sobre o comportamento deveriam seguir a uniformidade do procedimento experimental, assim como de outras ciências como a física e a química. Para Watson, conceitos como a imaginação, o julgamento e o raciocínio não eram adequados para os estudos da psicologia. O ponto de partida agora era o comportamento para a construção da nova ciência do homem. Assim, o comportamento era tomado como um "ramo objetivo e experimental da ciência natural", com objetivos específicos de previsão e controle do comportamento.

Anterior a Watson, Edward Lee Thorndike (1874-1949), a partir dos estudos sobre comportamento animal, elaborou uma teoria de aprendizagem objetiva e mecanicista, com enfoque no comportamento manifesto. “Thorndike acreditava que o psicólogo devia estudar o comportamento, não os elementos mentais ou a experiência consciente, e assim reforçava a tendência rumo à maior objetividade iniciada pelos funcionalistas" (Schultz e Schultz, 2005, p. 235). Thorndike desenvolveu a lei do efeito ${ }^{26}$ em 1898 , que foi de grande utilidade para a Psicologia Comportamentalista.

Outra escola de pensamento que também surgiu no início do século $\mathrm{XX}$, mais especificamente se firmando no período entre guerras, foi a psicologia dinâmica, representada pela psicanálise. A psicanálise, que nasceu a partir dos estudos da prática médica de Sigmund Freud (1856-1939), recuperou para a Psicologia "a importância da afetividade, postulando o inconsciente como objeto de estudo, quebrando, assim a tradição da Psicologia como ciência da consciência e da razão" (Bock, Furtado e Teixeira, 2002, p. 45). O momento de surgimento da psicanálise se intercalou, pois, com as demais teorias, mas o seu reconhecimento nos Estados Unidos só foi efetivo a partir da morte de seu fundador:

[...] Cronologicamente, a psicanálise se sobrepõe às demais escolas de pensamento da psicologia. Observe-se a situação em 1895, quando Freud publicou o primeiro livro, marcando o início formal do novo movimento. Wundt estava com 63 anos, e Titchener, com 28, depois de passar apenas dois anos em Cornell, estava começando a desenvolver a psicologia estrutural. O espírito funcionalista começava a florescer nos Estados Unidos. Nem o behaviorismo, nem a psicologia da Gestalt haviam sido propostos; Watson tinha 17 anos, e Wertheimer, 15. Todavia, em 1939, ano da morte de Freud, o universo da psicologia havia mudado completamente. A psicologia wundtiana, o estruturalismo titcheriano e a psicologia funcional já faziam parte do passado. A psicologia da Gestalt era transplantada da Alemanha

\footnotetext{
${ }^{26}$ De acordo com essa lei, todo comportamento de um organismo vivo (um homem, um pombo, um rato, etc.) tende a se repetir, se nós recompensarmos (efeito) o organismo assim que este emitir o comportamento. Por outro lado, o comportamento tenderá a não se repetir, se nós recompensarmos (efeito) o organismo assim que este emitir o comportamento. O comportamento tenderá a não acontecer se o organismo for castigado (efeito) após sua ocorrência. E, pela lei do Efeito, o organismo irá associar essas situações com outras semelhantes (Bock, Furtado e Teixeira, 2002).
} 
para os Estados Unidos, e o behaviorismo constituía a forma dominante da psicologia americana [...] (Schultz e Schultz, 2005, p. 346).

A Psicanálise, ao contrário das teorias psicológicas anteriores, surgiu dentro das "tradições da medicina e da psiquiatria a partir das tentativas de tratamento de pessoas rotuladas pela sociedade como doentes mentais" (Schultz e Schultz, 2005, p. 346).

Finalmente, nesse período de surgimento da Psicologia Científica nos Estados Unidos, destacou-se a contribuição da psicologia da Gestalt ${ }^{27}$ e sua chegada em território americano, "postulando a necessidade de se compreender o homem como uma totalidade, contrapondo-se às abordagens mais científicas e resgatando um pouco da tradição filosófica nos estudos psicológicos" (Bock, Furtado \& Teixeira, 2002, p. 43).

As escolas de pensamento do behaviorismo e da psicanálise, que eram radicalmente antinômicas quanto às perspectivas e propostas, constituíram-se nos movimentos mais importantes do desenvolvimento da Psicologia Científica americana.

O surgimento da Psicologia Científica nos Estados Unidos, permeado pelas abordagens psicológicas que floresceram na Europa e nas universidades americanas, fomentaram a formação dos primeiros psicólogos que contribuíram para o surgimento de diferentes formas de psicologia aplicada. Dentre elas, a Psicologia do Consumidor, que em 1960 se firmou como campo de estudo e aplicação, especificamente para a área de Marketing e os estudos sobre o comportamento do consumidor.

Após a década de 1960 até o início do novo século, a ampliação dos estudos sobre o comportamento do consumidor recebeu contribuição específica das escolas de pensamento da psicologia cognitiva e da psicologia social.

\section{2 - A contribuição dos pioneiros da psicologia do consumidor nos Estados Unidos.}

A Sociedade de Psicologia do Consumidor ${ }^{28}$ foi fundada em 1962, dois anos após a criação da Divisão 23 da APA - Divisão de Psicologia do Consumidor com a missão específica de promover a ciência da Psicologia do Consumidor. Em 1988 passou a ser uma entidade independente, mas manteve-se ligada à APA e à sua prestigiada divisão.

\footnotetext{
27 "Mais ou menos na mesma época em que a revolução behaviorista aglutinava forças nos Estados Unidos, a revolução da Gestalt tomava conta da psicologia na Alemanha. Essa revolução consistia em um protesto contra a psicologia wundtiana, e viria mais tarde a se tornar um testemunho da importância das ideias de Wundt como fonte de inspiração para o surgimento de novas visões e como base para o lançamento de novos sistemas de psicologia" (Schultz e Schultz, 2005, p. 317).

${ }^{28}$ Retirado do World Wide Web <http://www.myscp.org/about/apa_div23.aspx > em 24 de março de 2013.
} 
Desde sua fundação, essa área específica da Psicologia se dedicou ao conhecimento e pesquisas que aproximassem os estudos sobre o comportamento de consumo e suas influências psicológicas nas atitudes, necessidades e desejos dos consumidores. A aproximação e a contribuição da ciência da psicologia nessa área, em alguns momentos, refletiu a tendência de tornar a psicologia uma atividade mais prática, assim como aconteceu com a sua aproximação na área industrial, na educação e nas forças armadas. Entretanto, a necessidade econômica, fruto do desenvolvimento capitalista de aprofundar esses estudos, estimulou acadêmicos, desde o início do século $\mathrm{XX}$, a dedicarem suas pesquisas e experimentos para desvendar as relações entre consumidor e consumo.

Os psicólogos que se aproximaram das áreas de Marketing e Publicidade encontraram campo fértil para desenvolverem suas pesquisas. Na segunda metade do século XIX, a indústria da publicidade desenvolveu-se nos Estados Unidos como resultado do crescimento econômico da jovem nação. Entre 1850 e 1900, a expansão do parque fabril, da tecnologia e do transporte, bem como a explosão da produtividade nas fábricas motivaram o aumento no volume das vendas, diversificação dos produtos e o surgimento da concorrência. A publicidade nesse contexto foi fundamental para a aceleração do crescimento.

A atividade publicitária que, de certa forma, estava atrelada ao modelo de crescimento econômico adotado pelos Estados Unidos, desenvolveu-se após a segunda metade de 1800, quando começaram a surgir os modelos de agência e a figura dos redatores e agentes de publicidade, com o objetivo de incentivar e incrementar as vendas dos produtos e serviços. Segundo Coon (1994), as técnicas publicitárias, de montagem dos anúncios, a criação das marcas, a utilização de cores e imagens surgiram, de forma pouco profissional, por volta de 1741, quando foram identificados os primeiros anúncios em jornais da Filadélfia. Os anúncios apareciam com frequência em informativos religiosos. Posteriormente, nos anos 1880 e 1890, algumas agências já começavam a se especializar e a oferecer, além da montagem de anúncios, a criação de marcas e a responsabilidade pela criação e design dos anúncios. Começavam a criar um padrão estruturado para produção das peças e uma forma específica de apresentar os anúncios nos jornais e periódicos da época, sempre com o objetivo de incrementar as vendas.

Durante esse período surgiram duas formas de se conceber, criar e produzir anúncios publicitários: a primeira forma estava pautada pela visão mais racional do homem. Predominavam os formatos mais descritivos de anúncios, onde eram enfatizadas as características físicas, preço e ponto de venda dos produtos. O público consumidor era visto como "incapaz" de agir contra a sua vontade. Esta perspectiva era pautada na teoria 
econômica clássica que considerava as pessoas como se fossem "interessadas naturalmente" pelos produtos. A ênfase nas estratégias de abordagem eram o preço (razoável), e os pontos de venda (Haugtvedt et. al, 2007).

Por volta de 1910, esse modelo foi substituído pela abordagem "não racional”. Os adeptos achavam que as "emoções do público poderiam ser manipuladas e que as pessoas realmente poderiam ser persuadidas a adquirir bens" (Haugtvedt et. al, 2007). As teorias psicológicas sobre estados inconscientes e motivacionais a partir da psicanálise freudiana, e o reforço mecânico do comportamento a partir do behaviorismo de Watson, contribuíram para o desenvolvimento dessas abordagens mais emocionais pelos profissionais da publicidade.

Entre os estudantes de Wundt destacaram-se aqueles que reforçaram seus estudos na abordagem mentalista e voltaram seus interesses para a área da publicidade: Edward Wheeler Scripture (1864-1943), na Universidade de Yale, Harlow Gale (1862 -1945), na Universidade de Minnesota, e Walter Dill Scott (1869-1955), na Northwestern University. Entretanto, outras escolas de pensamento em psicologia já estavam presentes nas universidades e também contribuíram para os estudos dos pioneiros da psicologia do consumidor:

No início do novo século a abordagem mentalista tinha dois desafios: o behaviorismo e a psicologia dinâmica. Os dois autores pioneiros do behaviorismo eram Edward Lee Thorndike (1874-1949) e John Broadus Watson (1878-1958). Cada qual dentro de seus estudos tentaram desacreditar a abordagem mentalista (assim como a abordagem funcional), defendendo uma visão mecanicista do comportamento. A psicologia dinâmica refletia a dinâmica (mudança) do comportamento humano, prescrevia que o homem era melhor entendido por seus instintos, inconscientes mas como ações biológicas. Os dois autores proponentes dessa abordagem foram Sigmund Freud (1856-1939) e William McDougall (1938-1981) (Haugtvet et. al, 2007).

O reflexo das pesquisas desses psicólogos para a teoria da publicidade aplicada ao marketing estimulou os publicitários a se especializarem e buscarem a academia e a pesquisa científica para seus trabalhos. O tema "psicologia" passou a ser trabalhado na prática pelos profissionais de mercado e na publicação de manuais da prática publicitária. Um exemplo foi o livro de Claude Hopkins (1866-1932), A Ciência da Propaganda ${ }^{29}$, que ao descrever as técnicas publicitárias, dedicou um capítulo específico à psicologia aplicado a publicidade. Hopkins (1923/1966, p. 49) afirmou: “o publicitário competente deve entender de psicologia.

\footnotetext{
${ }^{29}$ Publicado originalmente em 1923 com o título: Scientific Advertising. Foi redator publicitário e estabeleceu, a partir de seu conhecimento e prática de mercado, algumas regras consagradas pela técnica publicitária. Em sua obra dá grande ênfase à Psicologia e, as leis que estabelece para a "Propaganda Científica", ou seja, a ciência da propaganda -se baseia fundamentalmente na Psicologia. (...)"(citado por Haugvetd et. al. 2007).
} 
Quanto mais conhecer sobre ela, melhor. Deve aprender que determinados efeitos levam a determinadas reações, e usar tal conhecimento para melhorar resultados e evitar erros".

A seguir, seguindo uma classificação cronológica, apresentaremos os pioneiros da psicologia, que se dedicaram aos estudos da publicidade e do marketing, a partir do início do século XX até a década de 1930, com as principais obras e trabalhos dos autores nessas áreas:

\section{Pioneiros da Psicologia do Consumidor - I}

\begin{tabular}{|c|c|}
\hline NOME & TRABALHO/OBRAS/ARTIGOS \\
\hline $\begin{array}{l}\text { E. W. Scripture } \\
(1862-1943)\end{array}$ & $\begin{array}{l}\text { Alguns autores o consideram como sendo ao lado de H. Gale (1896), um dos } \\
\text { precursores da psicologia do consumidor. Usou a noção de Wundt, que foi } \\
\text { seu professor na Alemanha, de "atenção voluntária" aproximando algumas } \\
\text { descobertas (leis) da psicologia e utilizando na publicidade. Por exemplo, } \\
\text { Scripture pesquisou a eficácia da sinalização e iluminação nas lojas para } \\
\text { observar a atenção à promoção comercial. Também considerou as emoções e } \\
\text { expectativas propondo que "o grau de atenção despendido para um objeto } \\
\text { depende da intensidade do sentimento despertado e que o nível de nossas } \\
\text { expectativas poderia determinar a quantidade de atenção dada a um objeto" } \\
\text { (Kuna, } 1976 \text { citado por Haugtvedt et al., 2007, p. 7). } \\
\text { Scripture, E. W. (1895). Thinking, feeling, doing. New York: Flood and } \\
\text { Vincent. }\end{array}$ \\
\hline $\begin{array}{l}\text { Harlow Gale (1862- } \\
\text { 1945) }\end{array}$ & $\begin{array}{l}\text { Iniciou seus experimentos através de uma pesquisa qualitativa que foi enviada } \\
\text { para profissionais de publicidade, colocando uma série de questionamentos } \\
\text { sobre os pareceres médicos sobre a melhor forma de atrair a atenção e induzir } \\
\text { a compra estimulada pela publicidade. A pesquisa exigiu um esforço } \\
\text { significativo e resultou em apenas um retorno de resposta de } 10 \% \text {. Gale então } \\
\text { seguiu a pesquisa com uma série de experimentos, empregando o } \\
\text { procedimento com taquistoscópio }{ }^{30}-\text { técnica que aprendeu com Wundt. A } \\
\text { pesquisa sobre atenção que ele examinou incluiu: palavras e publicidade e } \\
\text { imagens representativas, os níveis de exposição e as cores usadas na } \\
\text { publicidade. Pode ter sido o primeiro a usar a técnica de "ordem de mérito" } \\
\text { para a determinação da importância dos argumentos na mensagem. Gale } \\
\text { pediu para os entrevistados que classificassem as marcas numa ordem com } \\
\text { base na informação fornecida na publicidade. Esse método foi amplamente } \\
\text { utilizado por pesquisadores posteriores da publicidade e estudos de negócios, } \\
\text { mas contestada por Adams (1915). Gale limitou seu trabalho aos estudos } \\
\text { dentro da sala de aula e não quis estabelecer relações com os membros da } \\
\text { indústria da publicidade. Ele estava mais interessado em dar para seus alunos } \\
\text { uma experiência prática com a psicologia. }{ }^{31} \\
\text { Gale, H. (1896). On the psychology of advertising. In: H. Gale (Ed.) } \\
\text { Psychological studies. Minneapolis. }\end{array}$ \\
\hline $\begin{array}{l}\text { Hugo Munsterberg } \\
(1863-1916)\end{array}$ & $\begin{array}{l}\text { Munsterberg foi para Leipzig (Alemanha) em } 1882 \text { para estudar medicina. } \\
\text { Entretanto, após fazer um curso de psicologia com Wundt se entusiasmou } \\
\text { pela área. Fez doutorado com Wundt, recebendo o título em 1885, e formou- } \\
\text { se médico dois anos depois, na University of Heidelberg. Escreveu artigos }\end{array}$ \\
\hline
\end{tabular}

${ }^{30}$ Aparelho destinado a examinar a rapidez da percepção visual e a explorar o seu campo. Retirado do World Wide Web <http://www.dicio.com.br/taquistoscópio/> em 24 de março de 2013.

${ }^{31}$ Tradução livre e adaptado de Haugtvedt et. al (2007, p.5). 


\begin{tabular}{|c|c|}
\hline & $\begin{array}{l}\text { sobre o seu trabalho experimental em psicofísica, que Wundt criticou porque } \\
\text { "a pesquisa abordava o conteúdo cognitivo da mente ao invés dos estados do } \\
\text { sentimento". William James ofereceu-lhe a direção de um laboratório de } \\
\text { psicologia de Harvard (EUA). A partir desse momento foi seduzido pela } \\
\text { psicologia aplicada americana e mudou-se para a América. } \\
\text { Após passar } 10 \text { anos em Harvard, escreveu o primeiro livro em inglês, } \\
\text { American Trait (1902), que consistia numa análise psicológica, social e } \\
\text { cultural da sociedade americana. A partir dessa obra, passou a direcionar o } \\
\text { seu trabalho ao público em geral. Em } 1912 \text {, como professor visitante na } \\
\text { Universidade de Berlim, discutiu o tema "Experimentos sobre os efeitos da } \\
\text { publicidade, } 32 \text { em suas palestras, e publicou o resultado das discussões em } \\
\text { livro no mesmo ano. } \\
\text { É considerado, ao lado de Scott, como um dos precursores dos estudos de } \\
\text { psicologia aplicada à publicidade. }\end{array}$ \\
\hline $\begin{array}{l}\text { Walter Dill Scott } \\
(1869-1955)\end{array}$ & $\begin{array}{l}\text { Foi aluno de Wundt em Leipzig, mas passou a aplicar a nova ciência à } \\
\text { publicidade e aos negócios, ao retornar para os Estados Unidos. O seu } \\
\text { trabalho reflete a preocupação da escola da psicologia funcionalista com as } \\
\text { questões práticas } 33 \text {. } \\
\text { Foi um dos primeiros psicólogos a utilizar a psicologia aplicada na } \\
\text { propaganda. Em } 1909 \text { foi nomeado professor de publicidade e psicologia da } \\
\text { Escola de Comércio da Universidade de Northwestern, e em 1912, professor } \\
\text { de psicologia aplicada na mesma escola. Pouco depois de voltar da } \\
\text { Alemanha, enquanto estava ensinando na Universidade de Northwestern foi } \\
\text { abordado por um executivo da publicidade, procurando por ideias para torná- } \\
\text { la mais eficaz. Ele voltou a sua atenção para essa área e publicou dois livros. } \\
\text { Durante 1919-1920, foi presidente da Associação Americana de Psicologia } \\
\text { (APA) } 34 \text {. Em 1912 fundou a Companhia Scott, uma empresa de consultoria } \\
\text { que utilizou métodos psicológicos para resolver problemas práticos de } \\
\text { negócios. Ele também foi o fundador e primeiro presidente da Associação dos } \\
\text { Professores Universitários de Publicidade. } \\
\text { Scott, W. D. (1903). Theory of advertising. Boston: Small, Maynard, \& Co. } \\
\text { Scott, W. D. (1908). The psychology of advertising. Boston: Small, Maynard, } \\
\text { \& Co. } \\
\text { Scott, W. D. (1908). A practical illuminator and its utility in a psychological } \\
\text { laboratory. Psychological Bulletin, } 5 \text { (February), } 44 \text {. } \\
\text { Scott, W. D. (1910). Personal differences in suggestibility. Psychological } \\
\text { Review, } \\
\text { 17(March), 147-154. } \\
\text { Scott, W. D. (invited articles from 1910-1916). Suggestion. Psychological } \\
\text { Bulletin, } 7 \text { (November 1910): 369-372; 8 (September 1911): 309-311; } 9 \\
\text { (July 1912): 269-271; 10 (July 1913): 269-270; 11 (July 1914): 250-252; } \\
\text { 12(June 1915): 225-226; 13 (July 1916): 266-268. }\end{array}$ \\
\hline
\end{tabular}

\footnotetext{
${ }^{32}$ Tradução livre e adaptado de Wiendieck (1997, p. 515).

33 "Ao deixar Wundt e Leipzig e retornar à Chicago da virada do século, as publicações de Scott passaram da teorização germânica para a praticidade americana. Em vez de explicar a motivação e os impulsos em geral, Scott dava orientações de como influenciar pessoas, inclusive os consumidores, o público em palestras e os trabalhadores (Von Mayrhauser, 1989, p. 61 citado por Schultz \& Schultz, 2005, p. 210).

${ }^{34}$ Retirado do World Wide Web <http://www.onread.com/writer/Scott-Walter-Dill-6096/> em 16 de dezembro de 2012.
} 


\begin{tabular}{|c|c|}
\hline & $\begin{array}{l}\text { Scott, W. D. (1916). The theory and practice of advertising. Boston: Small, } \\
\text { Maynard \& Co. }\end{array}$ \\
\hline $\begin{array}{l}\text { Daniel Starch (1883- } \\
\text { 1979) }\end{array}$ & $\begin{array}{l}\text { Diferentemente de Scott, Starch realizou uma análise mais científica dos } \\
\text { processos psicológicos aplicados à publicidade. Em vez de analisar opiniões } \\
\text { subjetivas sobre a psicologia da publicidade, partiu para o desenvolvimento } \\
\text { de testes. Reforçou a abordagem mentalista com foco na atenção, sugestão e } \\
\text { instinto. Introduziu o conceito de "interesses do consumidor", identificado } \\
\text { mais tarde como "apelos". Em 1924, enquanto ainda estava em Harvard, } \\
\text { Starch se envolveu na supervisão de pesquisas da Associação Americana de } \\
\text { Agências de Publicidade. Em 1932, Starch deixou a academia e abriu a } \\
\text { Daniel Starch \& Staff, uma empresa de pesquisa de marketing, oferecendo } \\
\text { para as empresas pesquisa sobre a eficiência de seus anúncios. Starch tornou- } \\
\text { se conhecido por suas inovaçoses metodológicas, incluindo o "Procedimento } \\
\text { de Reconhecimento Starch" (Starch Recognition Procedure), em 1922, que } \\
\text { media os hábitos de consumo de leitura e o Buyometer, em 1948, o qual } \\
\text { isolava a influência da publicidade em revistas sobre as vendas. Ele se } \\
\text { aposentou em 1968 com a idade de } 85 \text { anos. } \\
\text { Starch, D. (1910). Principles of advertising: a systematic syllabus. Madison, } \\
\text { WI: University Cooperative Co. } \\
\text { Starch, D. (invited articles from 1911-1916). Auditory Space. Psychological } \\
\text { Bulletin, } 8 \text { (July 1911: 232-233; } 9 \text { (July 1912): 254-255; 12 (June 1915): } \\
\text { 213-214; 13 (July 1916): 264-265. } \\
\text { Starch, D. (1914). Advertising: its principles, practice and technique. New } \\
\text { York: D. Appleton. } \\
\text { Starch, D. (1923). Principles of advertising. Chicago: A.W. Shaw. }\end{array}$ \\
\hline $\begin{array}{l}\text { Harry Levi } \\
\text { Hollingworth (1880- } \\
\text { 1956) }\end{array}$ & $\begin{array}{l}\text { Apesar de ter sido formado segundo a abordagem mentalista, Hollingworth, } \\
\text { que também era parte do corpo docente da Universidade de Columbia (1900), } \\
\text { "percebeu que era mais eficiente medir a verdadeira eficácia de um anúncio } \\
\text { no que diz respeito ao comportamento de compra". Assim como outros } \\
\text { psicólogos, se apropriou do pensamento behaviorista que surgiu nesse } \\
\text { momento histórico. Analisou em seu trabalho variáveis como imagens, texto, } \\
\text { tamanho, cor, posição e estilo de tipo nas propagandas impressas. Essas } \\
\text { variáveis eram aplicadas a respostas dos entrevistados, considerando também } \\
\text { diferenças individuais, gênero e questões socioeconômicas. Construiu o } \\
\text { primeiro painel de moradores da cidade de Nova York, uma primeira ideia de } \\
\text { se analisar o comportamento do consumo. } \\
\text { Na obra de Hollingworth Advertising: its Principles and Practice, escrita } \\
\text { com outros autores, forneceu uma lista de necessidades humanas (como uma } \\
\text { hierarquia) - entre elas, o conforto, o jogo, a sociabilidade, a concorrência, a } \\
\text { timidez, a vingança, o orgulho, como sendo representantes do indivíduo e não } \\
\text { parte de um estímulo específico. Nas funções da publicidade, ele incluiu a } \\
\text { "tabulação das necessidades fundamentais de homens e mulheres", a análise } \\
\text { do poder satisfatório da mercadoria em termos de necessidade do consumidor, } \\
\text { estabelecendo a associação entre necessidades e commodities (produtos sem } \\
\text { diferenciação). } \\
\text { Hollingworth, H. L. (1911). Experimental studies in judgment: judgments of }\end{array}$ \\
\hline
\end{tabular}




\begin{tabular}{|c|c|}
\hline & $\begin{array}{l}\text { the comic. Psychological Review, 8(March), 132-156. } \\
\text { Hollingworth, H. L. (1913). Advertising and selling: principles of appeals } \\
\text { and responses. New York: D. Appleton. } \\
\text { Hollingworth, H. L. (1916). Vocational psychology. New York: D. Appleton. } \\
\text { Hollingworth, H. L. (1920). The psychology of functional neuroses. New } \\
\text { York: D. Appleton. } \\
\text { Hollingworth, H. L. (1929). Vocational psychology and character analysis. } \\
\text { New York/London: D. Appleton. } \\
\text { Hollingworth, H. L. (1930). Abnormal psychology. New York: Ronald Press. } \\
\text { Hollingworth, H. L., \& Poffenberger, A. T. (1917). Applied psychology. New } \\
\text { York and London: D. Appleton. } \\
\text { Hollingworth, H. L., \& Poffenberger, A. T. (1917). Sense of taste. New York: } \\
\text { Maffat, Yard and Company. }\end{array}$ \\
\hline $\begin{array}{l}\text { John B.Watson } \\
(1848-1958)\end{array}$ & $\begin{array}{l}\text { A carreira de Watson na publicidade foi discutida e criticada por outros } \\
\text { profissionais da área, principalmente porque na indústria da publicidade } \\
\text { encontrou terreno fértil para exercer um trabalho de psicologia aplicada sobre } \\
\text { as questões do comportamento humano. Após ser afastado da universidade } \\
\text { em que atuava como docente, a Johns Hopkins University, no ano de 1928, o } \\
\text { pesquisado foi contratado pela J. Walter Thompson", onde realizou seus } \\
\text { estudos na área de predição e controle do comportamento. Nessa empresa, } \\
\text { Watson conduziu estudos sobre pesquisa de mercado, treinamento de pessoal } \\
\text { e encabeçou a criação e o desenvolvimento de muitas campanhas de } \\
\text { publicidade na década de 1920, incluindo os produtos infantis Johnson \& } \\
\text { Johnson (1924-1926), a pasta de dente Pebeco (1928-1929), e a linha de } \\
\text { cremes para tratamento de beleza Pond's (1928-1930). } \\
\text { As principais contribuições de Watson para a melhoria das técnicas } \\
\text { publicitárias foram: o uso do apelo às emoções (anterior a esse período, as } \\
\text { publicidades eram mais objetivas e destacavam as características físicas do } \\
\text { produto), como um fator de identificação com o público-alvo; o reforço dos } \\
\text { comandos e a presença do uso de um "testemunhal", como se fosse uma } \\
\text { autoridade na peça publicitária. O uso de "testemunhais" era classificado para } \\
\text { alguns autores como sendo "sem escrúpulos", pois os atores convidados para } \\
\text { a foto e a campanha eram pagos pelos seus serviços, o que levantava a } \\
\text { suspeita sobre a autenticidade de seu depoimento. Embora o seu trabalho mais } \\
\text { conhecido tenha sido aplicado à publicidade, foram suas realizações em } \\
\text { seleção de pessoal e gestão que continuam a ter um efeito hoje. Enquanto era } \\
\text { professor da Johns Hopkins, Watson desejava que o novo behaviorismo } \\
\text { tivesse valor prático; suas ideias não serviam apenas para serem aplicadas em }\end{array}$ \\
\hline
\end{tabular}

\footnotetext{
${ }^{35} \mathrm{Agên}$ cia de publicidade multinacional, fundada em 1864 por William James Carlton, e modificada por John Walter Thompson, em 1877, para J. Walter Thompson Company (até 2005). É considerada uma das mais antigas agências de publicidade do mundo. Em 1929, chegou ao Brasil como a primeira agência de publicidade internacional. De origem americana, a JWT foi pioneira na introdução da fotografia nos anúncios, na realização da primeira pesquisa de mercado, e em várias atividades na televisão brasileira. Desde sua fundação, tem sido responsável pelo atendimento de marcas líderes de mercado. Entre elas, estão parcerias com empresas como a Unilever (desde 1967), a Nestlé (desde 1957) e a Warner Lambert (desde 1973).
} 


\begin{tabular}{|c|c|}
\hline & $\begin{array}{l}\text { laboratórios, como também na vida real. Promoveu as especializações } \\
\text { aplicadas da psicologia e tornou-se consultor pessoal de uma grande } \\
\text { companhia de seguros. Além disso, oferecia cursos de psicologia aplicada à } \\
\text { publicidade aos alunos de administração da Hopkins, dando início a um } \\
\text { programa de treinamento de estudantes de pós-graduação para trabalharem na } \\
\text { área de psicologia industrial (Schultz \& Schultz, 2005, p. 258). } \\
\text { - Psychology as the behaviorist views it (1913) } \\
\text { - Behavior: an introduction to comparative psychology (1914) } \\
\text { - Psychology from the standpoint of behaviorist (1919) } \\
\text { - Behaviorism (1924) } \\
\text { - The ways of behaviorism (1926) }\end{array}$ \\
\hline $\begin{array}{l}\text { Harry Foster Adams } \\
(1882-1973)\end{array}$ & $\begin{array}{l}\text { Adams aplicou em suas pesquisas uma espécie de rigor matemático, } \\
\text { correlacionando vários elementos aplicados à publicidade. Em seus estudos } \\
\text { sobre memória, por exemplo, ele observou que as mulheres tinham mais } \\
\text { lembrança de produtos e marcas a partir da apresentação de imagens, e os } \\
\text { homens, a partir do tamanho dos anúncios. Esse autor produziu sua obra a } \\
\text { partir das ideias mentalistas e, apesar de respeitar as contribuições de } \\
\text { Hollingworth e Strong, foi crítico no uso do método de "order-of-merit" } \\
\text { (1915). Sua obra mais significativa aplicada à publicidade foi "Advertising } \\
\text { and its Mental Laws" (1916). } \\
\text { Adams, H. F. (1915). The adequacy of the laboratory test in advertising. } \\
\text { Psychological Review, 22 (September), } 402-422 \text {. } \\
\text { Adams, H. F. (1916a). Advertising and its mental laws. New York: } \\
\text { Macmillan. } \\
\text { Adams, H. F. (1916b). The relative memory values of duplication and } \\
\text { variation in advertising. Journal of Philosophy, Psychology and Scientifi c } \\
\text { Methods, 18, 141-152. } \\
\text { Adams, H. F. (1917). The memory value of mixed sizes of advertising. } \\
\text { Journal of Experimental Psychology, 2, } 448-465 \text {. } \\
\text { Adams, H. F. (1920). The effect of climax and anti-climax order of } \\
\text { presentation on memory. Journal of Applied Psychology, } 4,330-338 \text {. }\end{array}$ \\
\hline $\begin{array}{l}\text { Henry Dexter Kitson } \\
(1880-1970)\end{array}$ & $\begin{array}{l}\text { Kitson era professor de psicologia da Indiana University. Sua obra mais } \\
\text { significativa para os estudos da psicologia aplicada à publicidade foi The } \\
\text { Mind of the Buyer (1921), onde examinou a ideia do "fluxo de pensamento } \\
\text { em uma venda". Em suas análises, prescreveu as } 6 \text { etapas de uma venda: } \\
\text { atenção, interesse, desejo, confiança, decisão, ação e satisfação. O livro tem } \\
\text { uma abordagem eclética, citando pesquisadores e teóricos de todas as três } \\
\text { escolas de pensamento em psicologia predominantes na época: mentalista, } \\
\text { comportamental e dinâmica. } \\
\text { Outra contribuição de Kitson foram suas pesquisas sobre a posição das } \\
\text { imagens na publicidade e, mais especificamente, o uso da cor (1922), várias } \\
\text { formas de arte (1922), ilustrações e embalagens (1924), e ilustrações } \\
\text { contendo pessoas (1925). } \\
\text { Em 1921, Kitson apresentou o seu "método histórico de investigar problemas } \\
\text { na publicidade". Este parece ser o primeiro uso documentado da metodologia } \\
\text { de análise de conteúdo em estudos de publicidade. Em 1925 relatou uma } \\
\text { tendência no uso de ilustrações que continham pessoas na publicidade, depois }\end{array}$ \\
\hline
\end{tabular}




\begin{tabular}{|c|c|}
\hline & $\begin{array}{l}\text { de analisar vinte anos de anúncios publicados nas Revistas: "Evening Post", } \\
\text { "Literary Digest" e "Women's Home Companion". Este estudo contínuo em } \\
\text { ilustrações é um dos exemplos da pesquisa programática em psicologia do } \\
\text { consumidor. } \\
\text { Kitson, H. D. (1921). Amount and rate of increase in the use of illustrations. } \\
\text { Journal of Applied Psychology, 5, } 12 \text {. } \\
\text { Kitson, H. D. (1921). The use of the historical method in investigating } \\
\text { problems in advertising. Journal of Applied Psychology, 5-13. } \\
\text { Kitson, H. D. (1921). The mind of the buyer: the psychology of selling. New } \\
\text { York: Macmillan. } \\
\text { Kitson, H. D. (1922a). Color in magazine advertising. Journal of Applied } \\
\text { Psychology, 6, 64-66. } \\
\text { Kitson, H. D. (1922b). Minor studies in the psychology of advertising - } \\
\text { Development of art forms in magazine advertising. Journal of Applied } \\
\text { Psychology, 6, 59-64. } \\
\text { Kitson, H. D. (1923). Understanding the consumer's mind. The Annals of the } \\
\text { American academy of Political and Social Science, 110, 131-138. } \\
\text { Kitson, H. D., \& Campbell, J. J. (1924). The package as a feature in magazine } \\
\text { advertising. Journal of Applied Psychology, 8, 444-445. } \\
\text { Kitson, H. D., \& Allen, I. (1925). Pictures of people in magazine advertising. } \\
\text { Journal of Applied Psychology, 9, 367-370. }\end{array}$ \\
\hline $\begin{array}{l}\text { Albert T. } \\
\text { Poffenberger (1885- } \\
\text { 1977) }\end{array}$ & $\begin{array}{l}\text { Estudou na Universidade de Columbia e seu maior interesse era na psicologia } \\
\text { aplicada. Após uma série de estudos, ele publicou o livro Psychology in } \\
\text { Advertising (1925). Esta obra é uma espécie de recapitulação de todo o } \\
\text { trabalho realizado na área até então. Uma revisão completa de temas } \\
\text { tradicionais como: memória e atenção e foco na metodologia, as estatísticas e } \\
\text { medição. Poffenberger abordou novos níveis de compreensão, como por } \\
\text { exemplo: "sentindo o tom", através das análises sobre atitude, desejos } \\
\text { humanos, individuais e em grupo, entre outros. Outra obra desse psicólogo foi } \\
\text { Applied Psychology: Its Principles and Methods (1927). Nessa obra ele } \\
\text { definiu a psicologia aplicada como "todas as situações em que o } \\
\text { comportamento humano está envolvido e onde a economia de energia } \\
\text { humana é de importancia prática". Referente à publicidade, ele explorou a } \\
\text { venda, os desejos, hábitos e lógica do consumidor, fez uma crítica à } \\
\text { psicologia como tendo aplicado a publicidade e às vendas, ideias estratégicas. } \\
\text { Talvez, essa seja a primeira crítica do uso da psicologia aplicada a } \\
\text { publicidade que tenha focado apenas nos negócios que envolviam as relações } \\
\text { de mercado, desconsiderando a presença do consumidor como elemento } \\
\text { humano no processo. } \\
\text { Poffenberger, A. T. (1923a). The return coupon as a measure of advertising } \\
\text { efficiency. Journal of Applied Psychology, 7(3), 202-208. } \\
\text { Poffenberger, A. T. (1923b). The conditions of belief in advertising. Journal } \\
\text { of Applied Psychology, 7(1), 1-9. }\end{array}$ \\
\hline
\end{tabular}




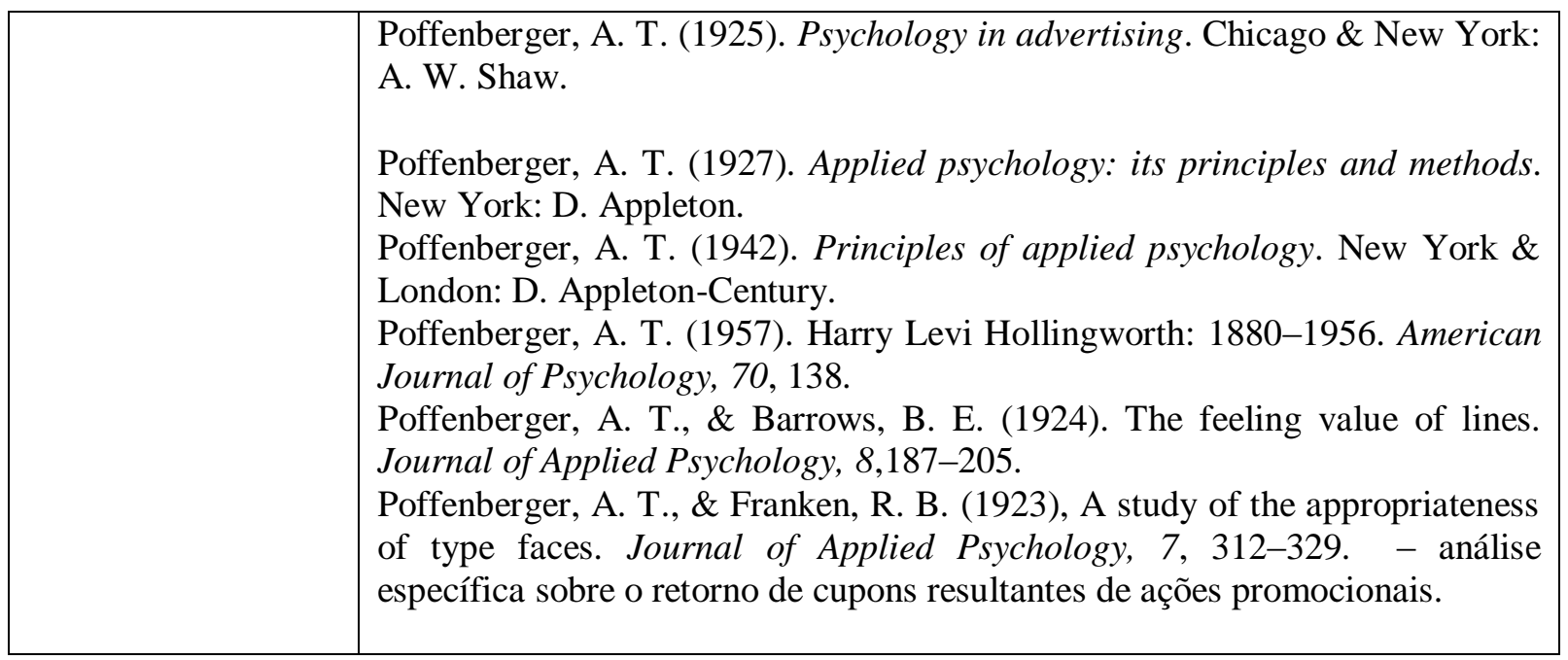

Tabela 4- Elaborada pelas autoras com base em Haugtvedt et. al (2007), Schultz e Schultz (2005).

Tradução nossa.

Após o período da Depressão Americana, mas ainda na fase da $2^{\mathrm{a}}$. Grande Guerra (1935-1945), a retomada do crescimento estimulou a economia e a demanda por novos produtos. Com a consolidação do rádio como meio de comunicação (década de 1930) e outros veículos, como cartazes e jornais, surgiu a necessidade da aplicação de pesquisas com o objetivo de investigar o recall ${ }^{36}$ dos anúncios veiculados, e se as mensagens eram eficientes para motivar a mudança de comportamento de compra dos clientes. Não foi um período marcado por grandes descobertas, como o que foi realizado pelos pioneiros, mas contribuiu para a ampliação das pesquisas experimentais e quantitativas, envolvendo audiência, retorno sobre as vendas, e o retorno das mensagens veiculadas nos meio de comunicação.

Os processos psicológicos: memória, sensações, percepção, entre outros, passaram a ser testados a partir da comparação e exposição dos clientes às mensagens publicitárias veiculadas nos diferentes meios: impressos (jornais, cartazes, revistas) e eletrônicos (primeiro o rádio e posteriormente a televisão, após a década de 1950). Como exemplos desses trabalhos destacaram-se:

- os estudos de memória que alguns psicólogos passaram a realizar através da comparação e eficácia de anúncios impressos e veiculados no rádio.

\footnotetext{
${ }^{36}$ Em publicidade e propaganda recall é o retorno da mensagem
} 


\section{Pioneiros da Psicologia do Consumidor - II}

\begin{tabular}{|c|c|}
\hline AUTORES/OBRAS/ARTIGOS & ESTUDOS \\
\hline $\begin{array}{l}\text { Burett, H. \& Dobell, E. (1925). } \\
\text { The curve of forgetting for } \\
\text { advertising material. Journal of } \\
\text { Applied Psychology, 9, 5-21. }\end{array}$ & $\begin{array}{l}\text { A partir da noção de Ebbinghaus }(1885)^{37} \text { sobre a ideia de curva } \\
\text { de esquecimento,esse estudo apresenta os resultados de uma } \\
\text { pesquisa a partir da apresentação de uma longa lista de produtos } \\
\text { e marcas de ficção projetados numa tela, em diferentes períodos } \\
\text { de tempo. O resultado da fixação da memória resultante foi } \\
\text { comparado com a mesma lista apresentada por meio de uma } \\
\text { locução através de um rádio. O resultado comparado com os } \\
\text { estudos sobre esquecimento em curva comparado com o teste de } \\
\text { memória em áudio deu a esse teste melhores resultados na } \\
\text { recordação e reconhecimento. }\end{array}$ \\
\hline $\begin{array}{l}\text { Brutt, H. \& Crockett, T. (1928). } \\
\text { A technique for psychological } \\
\text { study of poster board advertising } \\
\text { and some preliminary results. } \\
\text { Journal of Applied Psychology, } \\
\text { 12, 43-55. }\end{array}$ & Estudo sobre a memória em diferentes tipos de cartazes. \\
\hline $\begin{array}{l}\text { Stanton, F. N. (1934). Memory } \\
\text { for advertising copy presented } \\
\text { visually vs. orally.Journal of } \\
\text { Applied Psychology, 18, 45-64. } \\
\text { DeWick, H. (1935). The relative } \\
\text { effectiveness of visual and } \\
\text { auditory presentations of } \\
\text { advertising material. Journal of } \\
\text { Applied Psychology, 19, 245-264 }\end{array}$ & $\begin{array}{l}\text { Conduziram também estudos sobre a memória visual e falada. } \\
\text { Forneceram uma série de anúncios impressos e spots de rádio } \\
\text { em um estudo de contrapeso usando produtos comuns. As } \\
\text { marcas foram mencionadas três vezes em um script que durou } \\
\text { cerca de trinta e cinco segundos. Os resultados de ambos os } \\
\text { experimentos apresentaram uma diferença pouco significativa no } \\
\text { que diz respeito à recordação imediata. Entretanto, após cinco ou } \\
\text { sete dias iniciou-se o retorno de uma resposta a partir da } \\
\text { experiência de áudio. No estudo de Stanton, apareceram } \\
\text { diferenças significativas das respostas de áudio recuperadas até } \\
\text { vinte e um dias após o experimento. } \\
\text { DeWick constatou que a diminuição da memória visual e } \\
\text { auditiva começou após seis dias. A decadência visual na } \\
\text { memória foi significativamente maior do que a auditiva. Esses } \\
\text { estudos favoreceram a premissa de que a repetição dos anúncios } \\
\text { e a frequência de exposição estimulam a memória visual e falada } \\
\text { e garantem a "lembrança" do consumidor sobre produtos e } \\
\text { marcas. }\end{array}$ \\
\hline $\begin{array}{l}\text { Elliott, F. (1936). Memory for } \\
\text { visual, auditory and visual- } \\
\text { auditory material. In R. } \\
\text { Woodworth (Ed.), Archives of } \\
\text { Psychology (p. 199). New York: }\end{array}$ & $\begin{array}{l}\text { Retomou os estudos sobre memória visual e de estímulos } \\
\text { auditivos que datam de Ebbingaus. Desenvolveu uma série de } \\
\text { estudos comparando memória auditiva, visual em relação a } \\
\text { mensagem publicitária. Em vários momentos descobriu uma } \\
\text { vantagem no uso combinado dos recursos (áudio e imagem). Em }\end{array}$ \\
\hline
\end{tabular}

\footnotetext{
${ }^{37}$ Herman Ebbinghaus (1850-1909) foi o primeiro a investigar experimentalmente as propriedades da memória humana. Influenciado pelos empiristas britânicos, Ebbinghaus assumindo que no processo de cometer algo, a memória envolveu a formação de novas associações e que estas associações, seriam reforçadas com a repetição. Para observar esse processo, ele desenvolveu um conjunto de itens a serem comprometidas com a memória que não teria associações anteriores, as chamadas sílabas sem sentido. (Retirado do World Wide Web <http://users.ipfw.edu/abbott/120/Ebbinghaus.html> em 10 de fevereiro de 2013). Foi um psicólogo alemão que foi pioneiro no estudo experimental da memória, e é conhecido por sua descoberta da curva de esquecimento e do efeito de espaçamento. Ele também foi a primeira pessoa a descrever a curva de aprendizagem.
} 
Columbia University.

Elliott, F. R. (1937a). Attention effects from poster, radio and poster radio advertising of an exhibit. Journal of Applied Psychology, 21, 365-371.

Elliott, F. R. (1937b). Memory effects from poster, radio, and television modes of advertising an exhibit. Journal of Applied Psychology, 21, 504-512.

Elliott, F. R. (1937c). Memory for trade names presented in screen, radio and television advertisements. Journal of Applied Psychology, 21, 653667.

Cantril, H., \& Allport, G. W. (1935) The psychology of radio. New York: Harper and Brothers.

Kornhauser, A. W., \& Lazarsfeld, P. F. (1935). The technique of marketing research from the standpoint of a psychologist, Institute of Management Series \#16. New York, American Management Association.

Tabela 5- Elaborada pelas autoras com base em Haugtvedt et. al (2007), Schultz \& Schultz (2005) . Tradução nossa.

- Entre esses autores predominou os estudos sobre as características físicas dos anúncios impressos e cartazes, entre eles o impacto da cor na publicidade, análise sobre a posição do anúncio na página, estilo de letra e imagem, frequência de exposição. O foco desses trabalhos era a percepção do leitor em contato com o anúncio impresso.

\section{Pioneiros da Psicologia do Consumidor - III}

\begin{tabular}{|l|l|}
\hline AUTORES/OBRAS/ARTIGOS & TEMAS \\
\hline $\begin{array}{l}\text { Nixon, H. K. (1924). Attention and } \\
\text { interest in advertising. Archives of }\end{array}$ & $\begin{array}{l}\text { Estudos que comparavam os anúncios em cor e em } \\
\text { preto e branco. Acabou descobrindo que as mulheres } \\
\text { tendem a prestar mais atenção nos anúncios do que os } \\
\text { Psychology, 72, 5-67. }\end{array}$ \\
$\begin{array}{l}\text { Nixon, H. K. (1926). An investigation of } \\
\text { attention to Advertisements. New York, } \\
\text { Columbia University Press. }\end{array}$ & \\
$\begin{array}{l}\text { Nixon, H. K. (1927). A study of } \\
\text { perception of advertisements. Journal of }\end{array}$ & \\
\hline
\end{tabular}

outro estudo também tentou compreender as atitudes das pessoas em relação à publicidade de rádio.

Desenvolveu estudos comparativos de audiência a rádio e os reflexos de possíveis atitudes positivas e negativas das pessoas em relação à publicidade em rádio.

O parceiro de Kornhauser nesse estudo, Lazarsfeld, era um Phd em matemática da Universidade de Viena e já trabalhava com pesquisa sobre rádio na Europa, onde realizou o primeiro grande estudo sobre audiência de rádio escuta. 


Applied Psychology, 11, 135-142.
Nixon, H. K. (1931). Principles of selling.
New York: McGraw-Hill.
Nixon, H. K. (1942). Principles of selling
(2nd ed.). New York: McGraw-Hill Book
Company.

Sumner, F. C. (1932). Influence of color on legibility of copy. Journal of Applied Psychology, 16(2), 201-204.

Dorcus, R. (1932). Habitual word associations to colors as a possible factor in advertising. Journal of Applied Psychology, 16, 277-287

Dorcus, R. M. (1926). Color preferences and color associations. Journal of Genetic Psychology, 33, 399-434.

Cutler, T. (1930). The effectiveness of page size in magazine advertising. Journal of Applied Psychology, 14, 465-469.

Ferguson, L. W. (1934). Preferred Positions of advertisements in the Saturday Evening Post. Journal of Applied Psychology, 18, 749-756.

Ferguson, L. W. (1935). The importance of the mechanical features of an advertisement. Journal of Applied Psychology, 19, 521-526.

Lucas, D. B. (1937). The impression values of fixed advertising locations in the Saturday Evening Post. Journal of Applied Psychology, 21, 613-631.

Lucas, D. B., \& Benson, C. E. (1929a) The historical trend of negative appeals in advertising. Journal of Applied Psychology, 13, 346-356.

Lucas, D. B., \& Benson, C. E. (1929b) The relative values of positive and negative advertising appeals as measured by coupons returned. Journal of Applied Psychology, 13, 274-300.

Lucas, D. B., \& Benson, C. E. (1930a) The recall values of positive and negative advertising appeals. Journal of Applied Psychology, 14, 218-238.

Lucas, D. B., \& Benson, C. E. (1930b) Psychology for advertisers. New York: Harper.
Estudos sobre a influência da cor e a legibilidade.

Estudou a associação da percepção das pessoas aos anúncios coloridos e em preto e branco. Descobriu, após uma pesquisa de campo, que os "anúncios em cores traziam um retorno $53 \%$ a mais do que o similar em preto e branco" (1926, p. 65).

Pesquisas relacionando os efeitos da cor, o tamanho do anúncio e a colocação na página. Ele não relatou diferenças de recall para o mesmo anúncio que aparecia em revistas de tamanhos diferentes.

Apoiava as descobertas de Starch, comparando a posição dos anúncios de revista no Saturday Evening Post. Também encontrou algumas diferenças na posição e na questão da cor, realizou estudos observando eventuais diferenças de público-alvo: aqueles que compravam o jornal para ler contos e artigos, aqueles que compravam para ler o conteúdo de humor e aqueles que gostavam de anúncios.

Realizou um estudo mais aprofundado que Ferguson e descobriu que as mudanças relacionadas à posição e tamanho do anúncio impresso estavam relacionadas com a recordação e o reconhecimento. Os anúncios de página inteira, colocadas tanto na esquerda quanto na direita não sofriam diferenças na lembrança, mas os anúncios menores, colocados na página direita, eram reconhecidos mais rapidamente do que os mesmos na página esquerda.

A obra Psychology for Advertisers, publicada em parceria com Benson, era uma espécie de manual para os cuidados que os anunciantes deviam ter ao aprovar um anúncio publicitário considerando, todas as descobertas mecânicas.

As descobertas de Lucas lhe renderam o cargo de Diretor técnico da Advertisign Research Foundation. 
Lucas, D. B. (1937) Th e impression values of fixed advertising locations in the Saturday Evening Post. Journal of Applied Psychology, 19, 613-631.

Lucas, D. (1940) A rigid technique for measuring the impression values of specifi c magazine advertisements. Journal of Applied Psychology, 24, 778790.

McNamara, J. J. (1941). "A new method for testing advertising effectiveness through eye movement photography." Psychological Record, Vol. 4, 399-459.

McNamara, J. J. \& Tiffin, J. (1941). The distracting effect of nearby cartoons on the attention holding power of advertisements. Journal of Applied Psychology, 25, 524-527.

Davis, R., \& Smith, H. (1933). Determinants of feeling tone in type faces. Journal of Applied Psychology, 17, 742764.

Schiller, G (1935) An experimental study of the appropriateness of color and type in advertising. Journal of Applied Psychology, 19, 652-664.

Klapp, O. E. (1941) Imitation-value in advertising. Journal of Applied Psychology, 25, 243-250.
Deu continuidade aos estudos mecânicos sobre posicionamento e tamanho de anúncios.
Deu continuidade aos estudos de Poffenberger e ampliou os estudos sobre as percepções a diferentes tipos de fontes (grafia das letras). Em sua pesquisa, os entrevistados foram convidados a combinar tipos de letra com os produtos anunciados, bem como as emoções manifestadas, revelando algumas diferenças com base em características do tipo de letras, como o tamanho, a condensação, a ousadia e o uso do itálico.

Replicou o estudo de Poffenberger e Franken (1923), analisando a eficácia de certos tipos de letra como representando determinados produtos. No entanto, em seu estudo também considerou o estudo das fontes.

Testou a questão do uso das fotos em anúncios, e as fotos incluindo pessoas relacionadas ao uso dos produtos. Descobriu o aumento da relevância do anúncio no público leitor.

Tabela 6- Elaborada pelas autoras com base em Haugtvedt et. al (2007) e Schultz \& Schultz (2005) . Tradução nossa.

- Na primeira metade do século XX, muitos psicólogos desenvolveram trabalhos na área da psicologia industrial, e voltaram seus estudos sobre como deveria se desenvolver um vendedor. Alguns autores da área de Marketing denominam esse período como a Era de Vendas, caracterizado pela necessidade de "forçar as vendas de forma agressiva, utilizando as mais variadas técnicas de persuasão para conquistar a compra do cliente. O negócio era vender o que se produzia, independentemente do que o mercado quisesse comprar" (Zanotta \& Zanotta, 2001, p. 121). Nesse sentido, o foco na eficácia dos vendedores era cuidadosamente investigado através da análise de resultados e satisfação dos clientes. 
Pioneiros da Psicologia do Consumidor - IV

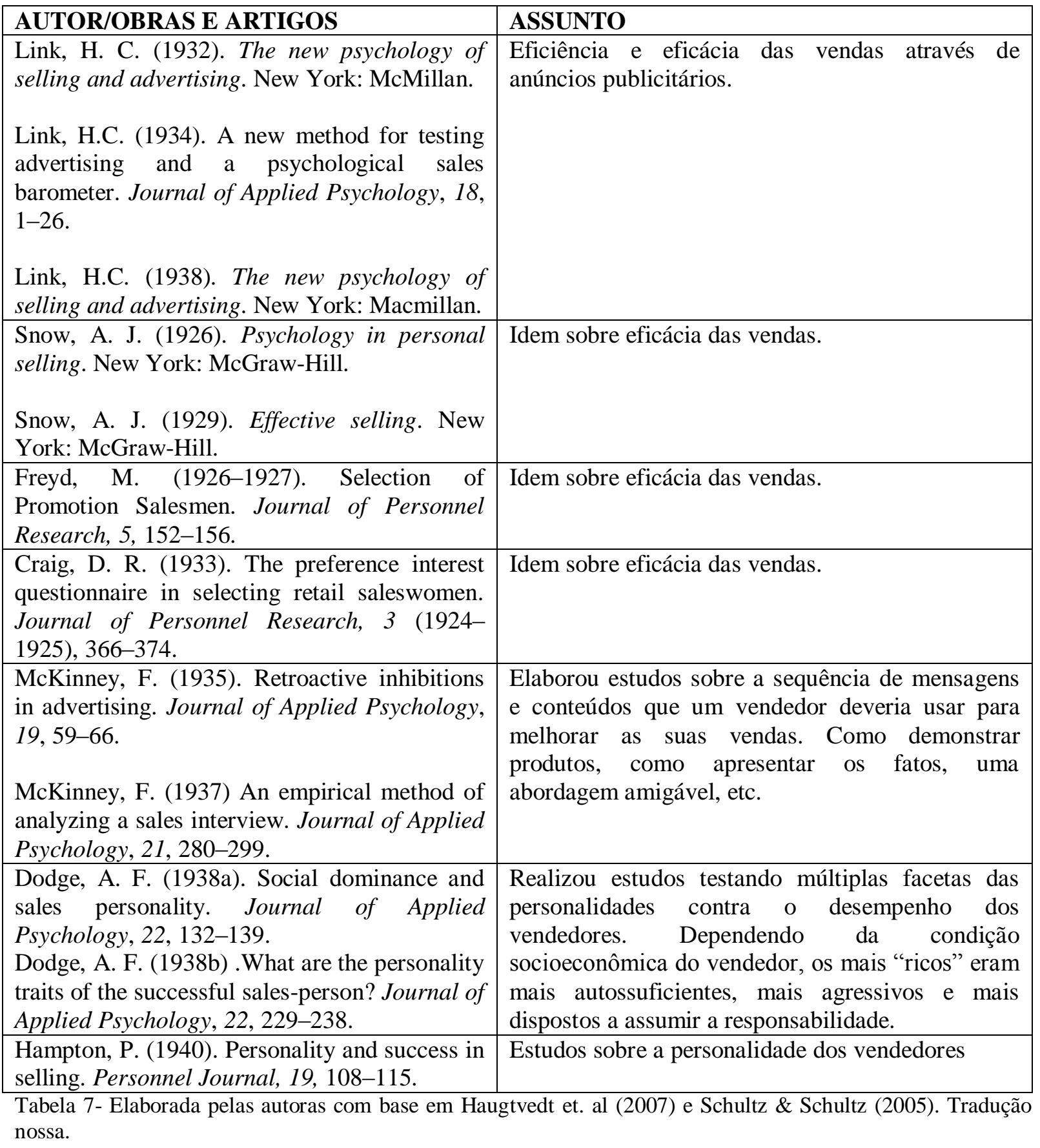

- O uso do recall e os testes de associação foram aplicados a diferentes métodos de pesquisa com o objetivo de investigar o mercado consumidor e a reação dos consumidores a diferentes produtos e a forma como eram divulgados. 
Pioneiros da Psicologia do Consumidor - V

\begin{tabular}{|l|l|}
\hline AUTORES/OBRAS E ARTIGOS & ASSUNTO \\
\hline $\begin{array}{l}\text { Donovan, H. (1924). Advertising response. } \\
\text { Philadelphia: J. B. Lippincott. }\end{array}$ & $\begin{array}{l}\text { Examinou a associação dos produtos de commodity } \\
\text { (produtos sem diferenciação no mercado) com } \\
\text { produtos de marcas já reconhecidas. }\end{array}$ \\
\hline $\begin{array}{l}\text { Asher, E. J. (1928). The association test as a } \\
\text { means of determining the relative familiarity } \\
\text { of retail stores. Journal of Applied } \\
\text { Psychology, 12,437-446. }\end{array}$ & $\begin{array}{l}\text { Revelou uma correlação entre a publicidade em } \\
\text { jornais o o recall de certos tipos de lojas de varejo } \\
\text { farmácias, lojas para mulheres, imobiliárias, } \\
\text { agências de automóveis, etc.), e não outros (lojas de } \\
\text { calçados, restaurantes, lojas de música e joias). Um } \\
\text { dos benefícios desse estudo era a capacidade de dar } \\
\text { ao anunciante uma habilidade para focar nos } \\
\text { produtos e marcas concorrentes. }\end{array}$ \\
\hline $\begin{array}{l}\text { Karslake, J. (1940). The Purdue Eye- } \\
\text { Camera: a practical apparatus for studying } \\
\text { the attention value of advertisements. } \\
\text { Journal of Applied Psychology, 24(4) 417- } \\
\text { 440. }\end{array}$ & $\begin{array}{l}\text { Apresentou um estudo relacionado com uma nova } \\
\text { técnica - Purdue Eye Camera. Relacionava } \\
\text { resultados com as medidas colhidas na câmera - } \\
\text { testes de atenção. }\end{array}$ \\
\hline
\end{tabular}

Tabela 8- Elaborada pelas autoras com base em Haugtvedt et al (2007), Schultz \& Schultz (2005). Tradução nossa.

Especificamente no ponto de venda, intensificaram as pesquisas sobre embalagem.

Pioneiros da Psicologia do Consumidor - VI

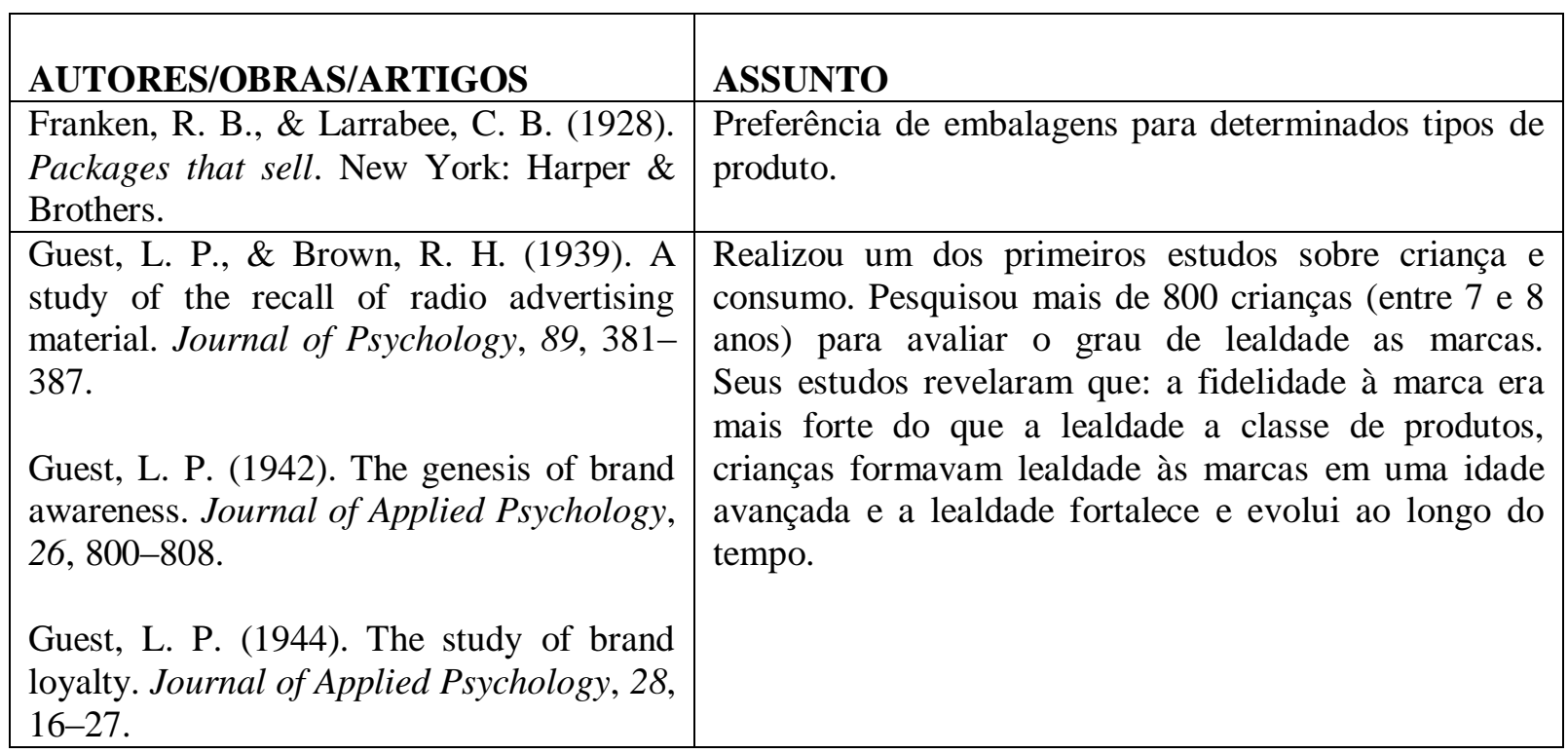

Tabela 9- Elaborada pelas autoras com base em Haugtvedt et al (2007) e Schultz \& Schultz (2005). Tradução nossa.

- Em 1940, o psicanalista Ernest Dichter (1907-1991) foi contratado por uma agência de propaganda americana e inaugurou uma nova metodologia de pesquisa baseada na psicanálise freudiana, aplicada à psicologia e à publicidade. $\mathrm{O}$ psicanalista vienense emigrou para os Estados Unidos em 1937, após completar o seu doutorado na Áustria. Em solo americano, passou a usar o seu conhecimento de forma aplicada, focando o seu trabalho na 
tentativa de desvendar os motivos que levam os consumidores a consumirem. A sua ideia era realizar um verdadeiro "inventário psicológico" a partir dos motivos primários para realizar as compras até os mais complexos.

Foi considerado o fundador da pesquisa motivacional. Em sua metodologia, empregava "entrevistas em profundidade e técnicas projetivas para aproveitar os dois estados conscientes e subconscientes, para orientar o comportamento do consumidor" (Haugvtvedt et. al, 2007, p. 15). Em 1946 fundou o Institute for Motivational Research e desenvolveu pesquisas e consultoria para as principais indústrias americanas dessa época. Seus estudos também contribuíram para o desenvolvimento de diferentes produtos, sempre pautados na satisfação que o consumidor poderia ter ao adquiri-los. Dichter era também crítico sobre os estudos realizados pelos psicólogos pioneiros sobre comportamento do consumidor, pois afirmava que "os métodos do passado apenas arranhavam a superfície de como a publicidade e a venda produziam efeitos dinâmicos sobre o consumidor" (Haugvtvedt et. al, 2007, p. 15).

No primeiro parágrafo do prefácio de sua obra mais popular "Handbook of consumer motivation: the psychology of the world of objects" (1964, p. 8, tradução nossa), o autor destacou, através de exemplos a sua metodologia de pesquisa:

Este livro é destinado para o especialista em comunicações, seja em publicidade, vendas, marketing, promoção, relações públicas, ensino ou política. Em cada caso, ele lida com as motivações de seu público e as relações dessas motivações para com a mercadoria em questão. Ele pode estar vendendo um programa político ou social, sapatos, ou a conveniência de usar chapéus. Em cada caso, ele precisa saber mais do que os fatos puros de mercado ou informações técnicas sobre o seu assunto. Ele também tem que aprender a compreender o significado mais profundo dos produtos e serviços que ele está promovendo. Levar as pessoas a contribuir para a caridade requer o conhecimento da psicologia do "dar" e do significado simbólico de dinheiro. O especialista em relações públicas que está preocupado com a moda de usar chapéus na Alemanha requer mais do que uma percentagem de quantos homens desfilam com orgulho, sem um chapéu. Ele tem que ponderar o significado muitas vezes "subconsciente" de um chapéu e seu papel cultural.

Dichter foi muito além dos estudos do consumidor, inaugurando uma nova fase nas pesquisas sobre comportamento de consumo ao introduzir o estudo das motivações humanas a partir da psicanálise. O desenvolvimento da pesquisa motivacional de Dichter permitiu às empresas "entenderem que os consumidores que nem sempre tinham consciência das razões que embasam suas decisões de consumo" (Samara \& Morsch, 2005, p. 11). Através de técnicas psicanalíticas, Dichter (Samara \& Morsch, 2005, p. 11) revelou "motivações ocultas e subjetivas dos consumidores". 
O desenvolvimento das ciências cognitivas, a partir do final dos anos de 1950 até o final dos anos de 1960, proporcionou o desenvolvimento de novas técnicas de pesquisa empírica sobre a memória e a resolução de problemas. "Psicólogos, antropólogos e cientistas comportamentais passaram a estudar o comportamento humano para ajudar a compreender o desenvolvimento mental. Na década de 1980, os cientistas que exploravam o funcionamento do cérebro estavam examinando como as pessoas lidavam com informações e tomada de decisões." 38

$\mathrm{Na}$ atualidade, no domínio das neurociências, alguns pesquisadores trabalham em pesquisas sobre comportamento de compra e enfatizam as questões sobre os instintos e desejos inconscientes relacionados à necessidade e à vontade de consumir. Para esses pesquisadores, é a razão e não a emoção que impulsiona o comportamento de compra. Sendo assim, a compra se dá mais por "impulso" do que por um comportamento racional pautado nas necessidades reais de aquisição de um produto ou serviço. É sobre esse pilar da "não consciência" durante o ato de compra que alguns publicitários e profissionais de marketing se apoiam para desenvolver as estratégias de marketing de seus produtos. Na medida em que os profissionais recebem uma formação mais voltada às ciências humanas, aplicada ao exercício do trabalho prático do publicitário e do profissional de marketing, muitos dos problemas relacionados aos excessos do consumo poderiam ser alterados e, até mesmo, eliminados das práticas predatórias de mercado.

Samara e Morsch (2005, p. 11), ao citarem Solomon (2002), analisaram os desafios da pós-modernidade sobre a evolução dos estudos sobre consumidores:

[...] O consumismo, uma característica do mundo em que vivemos, tem sido muito discutido, principalmente sob a perspectiva de seu significado. Estudos têm apontado que consumimos não apenas pelo suprimento de uma necessidade com base na utilidade dos produtos, mas igualmente pelo significado dos próprios produtos, pelo que eles nos dão como benefício adicional (imagem, pertencimento, status, etc.). O consumo pode representar uma experiência (reação emocional ou estética a objetos de consumo), uma integração (conhecer e manipular objetos de consumo para expressar aspectos do eu ou da sociedade), uma classificação (atividades em que os consumidores se envolvem para comunicar, para si próprios ou para outros, sua associação com objetos) ou um jogo (usando para participar de uma experiência mútua e fundir suas identidades com a do grupo) [...].

\footnotetext{
${ }^{38}$ Retirado do World Wide Web <http://www.economist.com/node/21541706> em 29 de março de 2013. Tradução nossa do original em inglês.
} 
A Psicologia do Consumidor em suas raízes, isto é, até a década de 1950, estive ligada à psicologia industrial/organizacional. Somente depois do reconhecimento pela APA da Divisão 23, específica sobre esse campo da psicologia, é que os estudos passaram a ser sistematizados. Não se sabe ao certo qual a escola de pensamento que predominou entre os primeiros psicólogos que se aprofundaram nas pesquisas sobre psicologia e publicidade, mas a influência da publicidade aos poucos foi sendo substituída pelas influências das estratégias em vendas. E nesse momento, os estudos sobre comportamento do consumidor passaram a ser objeto de estudo das áreas de negócios, entre elas, a área de Marketing.

Figura $\mathrm{x}$ - Linha de tempo

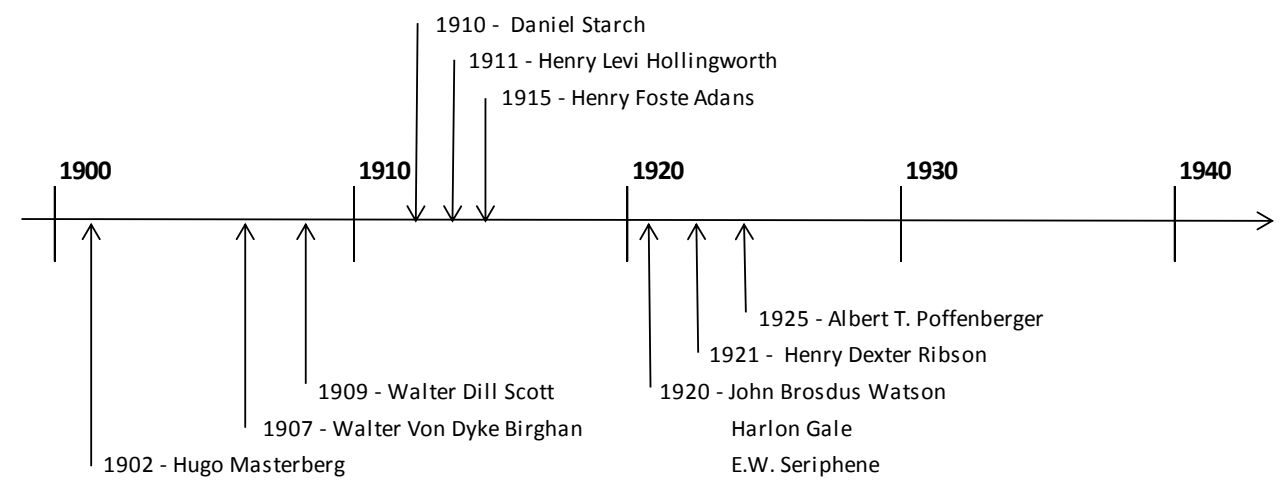

Figura 2 - Linha do tempo - Pioneiros da psicologia do consumidor (1900-1940)

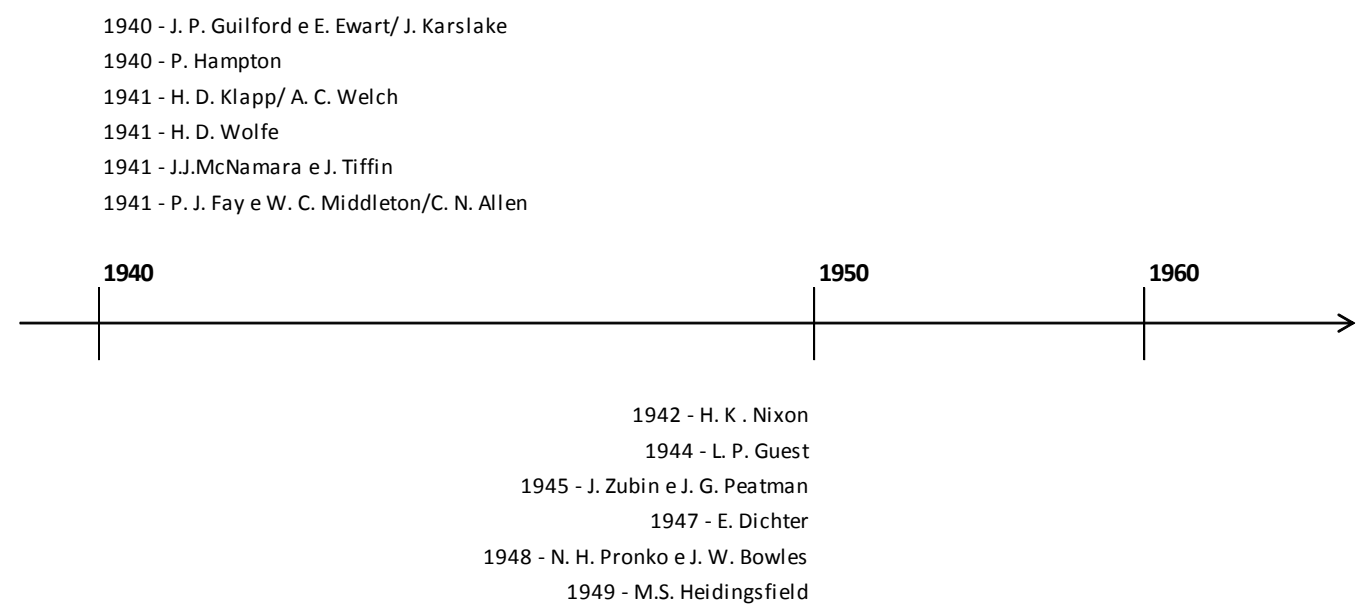

Figura 3 - Linha do tempo - Pioneiros da psicologia do consumidor (1940 -1950) 


\section{3 - O conceito de consumidor e as novas tendências do Marketing.}

Por se tratar de uma ciência multidisciplinar, a área de Marketing recebeu uma contribuição significativa dos estudos científicos da Psicologia. A retomada da economia americana nos anos de 1950, e o avanço dos estudos ligados ao comportamento do consumidor, a partir do reconhecimento da APA dessa área específica de estudos psicológicos, abriram novas possibilidades de pesquisas e novas tendências surgiram para os profissionais de mercado.

O conceito de consumidor está atrelado às atividades mercadológicas que contemplam o planejamento do produto, do preço, do ponto de venda e da publicidade. Os profissionais da área de Marketing conceituam o termo "consumidor" como aquele que consome, adquire produtos para seu uso pessoal, de sua família, empresa, etc. O consumidor também assume diferentes papéis no processo de compra, pois nem sempre é o usuário do produto. Kotler (2000, p.199) distinguiu cinco diferentes papéis:

Iniciador: pessoa que sugere a ideia de comprar um produto ou serviço; Influenciador: pessoa cujo ponto de vista ou conselho influencia na decisão; Decisor: pessoa que decide sobre quaisquer componentes de uma decisão de compra (comprar, o que comprar e como comprar, ou onde comprar); Comprador: pessoa que efetivamente realiza a compra; Usuário: pessoa que consome ou usa o produto ou serviço.

A partir do levantamento histórico e da interface entre as áreas da Psicologia e do Marketing, é possível identificar diferentes abordagens utilizadas por essas áreas para a conceituação do termo consumidor. Algumas vezes isto está explícito dentro da abordagem mercadológica e, outras vezes, não tão explícito, mas em diferentes épocas, a aproximação entre as áreas da Psicologia e do Marketing parece ter sido determinante para o comportamento de compra esperado. Essa constatação só foi possível após o levantamento da aproximação entre os psicólogos pioneiros da psicologia científica americana e seus estudos voltados às práticas de mercado e à propaganda. É importante destacar que na literatura acadêmica da área de Marketing não existe nenhum autor ou referência que apresenta, no contexto histórico, os diferentes conceitos de consumidor. O termo consumidor está sempre atrelado ao papel desempenhado ou ao comportamento assumido no ponto de venda.

Dessa forma, após as análises da perspectiva histórica de ambas as áreas, pode-se reunir, no quadro abaixo, as ideias predominantes sobre o conceito e o comportamento do consumidor, em cada época específica, bem como sua aproximação com as ideias psicológicas do mesmo período num quadro-resumo analítico: 


\begin{tabular}{|c|c|c|}
\hline PERÍODO & $\begin{array}{l}\text { CONCEITO DE CONSUMIDOR A } \\
\text { PARTIR DA HISTÓRIA DO } \\
\text { PENSAMENTO EM MARKETING }\end{array}$ & $\begin{array}{l}\text { APROXIMAÇÃO COM AS IDEIAS } \\
\text { PSICOLÓGICAS }\end{array}$ \\
\hline $1910-1920$ & $\begin{array}{l}\text { Consumidor } \\
\text { concorrência. }\end{array}$ & $\begin{array}{l}\text { Aproximação das "leis" da psicologia } \\
\text { aos estudos da publicidade - atenção, } \\
\text { retenção e memória dos objetos nos } \\
\text { pontos de venda. }\end{array}$ \\
\hline $1920-1930$ & $\begin{array}{l}\text { Consumidor influenciador - passa a } \\
\text { ser "ensinado" a comprar - estímulos } \\
\text { através de propaganda e da } \\
\text { abordagem de vendedores. }\end{array}$ & $\begin{array}{l}\text { Behaviorismo de Watson - reforço das } \\
\text { mensagens, testemunhal e apelo às } \\
\text { emoções. }\end{array}$ \\
\hline $1930-1950$ & $\begin{array}{l}\text { Consumidor mais } \\
\text { crítico/influenciador - resultado do } \\
\text { período entre guerras e da ênfase da } \\
\text { propaganda para a venda de } \\
\text { diferentes produtos }\end{array}$ & $\begin{array}{l}\text { Desenvolvimento dos veículos de } \\
\text { comunicação - pesquisas quantitativas } \\
\text { e experimentais específicas sobre } \\
\text { índices de audiência, uso da cor nas } \\
\text { embalagens, design e recursos visuais, } \\
\text { análises sobre atitudes, desejos entre } \\
\text { outros. } \\
\text { Psicanálise - Ernest Dichter - } \\
\text { contratado por uma agência americana } \\
\text { - a ideia era realizar um "inventário } \\
\text { psicológico" a partir de motivos } \\
\text { primários para realizar as compras } \\
\text { indo até os mais complexos. }\end{array}$ \\
\hline 1960 & $\begin{array}{l}\text { O consumidor como parte de um } \\
\text { segmento de mercado: passa a ser } \\
\text { analisado de acordo com os } \\
\text { segmentos específicos de mercado- } \\
\text { influências do grupo, atitudes, } \\
\text { hábitos, referências socioeconômicas. } \\
\text { Ênfase nas características } \\
\text { psicológicas e formas de motivá-lo } \\
\text { para a compra. }\end{array}$ & $\begin{array}{l}\text { Desenvolvimento das ciências } \\
\text { cognitivas proporcionou o } \\
\text { desenvolvimento de novas técnicas de } \\
\text { pesquisa empírica sobre a memória e a } \\
\text { resolução de problemas. }\end{array}$ \\
\hline 1980 & $\begin{array}{l}\text { O consumidor crítico de seu papel } \\
\text { na sociedade - debate sobre os } \\
\text { temas consumismo } \\
\text { responsabilidade social. }\end{array}$ & $\begin{array}{l}\text { As neurociências }- \text { pesquisas sobre } \\
\text { comportamento de compra e ênfase } \\
\text { nas questões sobre os instintos e } \\
\text { desejos inconscientes relacionados à } \\
\text { necessidade e a vontade de consumir. } \\
\text { Ênfase na descoberta de novos } \\
\text { caminhos de abordagem do } \\
\text { consumidor. Uso de recursos que } \\
\text { visam os cinco sentidos (paladar, } \\
\text { olfato, visão, audição e tato) gerando } \\
\text { experiências de consumo. }\end{array}$ \\
\hline 2000 & $\begin{array}{l}\text { O consumidor digital }- \text { crítico, } \\
\text { participativo e interativo. Consciente } \\
\text { de sua atuação no mundo e na } \\
\text { sociedade questiona o seu papel } \\
\text { como ser humano, resgate de valores } \\
\text { sociais e familiares. }\end{array}$ & $\begin{array}{l}\text { A busca pelo elemento humano - } \\
\text { enfase nas pesquisas qualitativas com } \\
\text { grupos de consumidores - pesquisas de } \\
\text { recall em redes sociais. Debate sobre } \\
\text { valores, expectativas e desejos dos } \\
\text { consumidores. Importante atuação do } \\
\text { psicólogo como parceiro nas } \\
\text { discussões sobre comportamento do } \\
\text { consumidor. }\end{array}$ \\
\hline
\end{tabular}

Tabela 10- Elaborada pelas autoras. 
No final da década de 1980 e início das décadas de 1990 e 2000, observaram-se as novas perspectivas do marketing: Marketing de Relacionamento, Cybermarketing, Marketing Social/Ambiental, e Marketing Experimental, que passaram a enfatizar o papel do consumidor nas relações de mercado, estando seus estudos focados na sua participação no contexto social, econômico e até mesmo político. O consumidor, que antes era parte significativa do objetivo final do processo mercadológico, o chamado "comprador", passou a ter papel de protagonista no processo, ao ser "ouvido" e questionado sobre suas necessidades e desejos de consumo. É importante ressaltar que as pesquisas sobre comportamento de consumo também tem como objetivo obter informações sobre possíveis demandas de produto a partir das análises psicológicas de grupos específicos de consumidores. Ou seja, nem sempre o que é uma necessidade real de consumo é algo que o mercado vai oferecer, dependendo do que é importante ou não para as economias de mercado. As pesquisas funcionam como indicadores de consumo e de necessidades e, na maioria das vezes, representam os interesses da indústria e do próprio mercado.

Em linhas gerais, as novas tendências tem como objetivo entender de forma mais completa o pensamento, os desejos e as necessidades dos consumidores, assim como os modos pelos quais eles interpretam o que lhes é imposto pelo mercado em termos de consumo. O foco principal das atividades mercadológicas passou a ser a experiência do consumidor, de uma forma mais ampla, envolvendo não apenas as questões relacionadas à satisfação das necessidades, mas sim à satisfação do ser humano consumidor.

As classificações para cada uma dessas tendências, segundo diferentes autores da área de marketing, estão discriminadas resumidamente abaixo:

- Marketing de Relacionamento: o foco principal dessa tendência, no final dos anos 80 era o relacionamento com clientes de uma forma direta, como a venda porta a porta ${ }^{39}$, ou através de canais de comunicação específicos, com a utilização de estratégias de marketing direto ${ }^{40}$. $\mathrm{O}$ objetivo desse trabalho era "criar vínculos", conhecer o cliente de modo mais completo e entender as suas necessidades de consumo. A expressão que mais caracterizava essa perspectiva era "O cliente em primeiro lugar", ou seja, sem o seu reconhecimento e sem essa proximidade via processo de compra ou canais de comunicação, o profissional de marketing não conseguiria criar a estratégia de "fidelização do cliente". Os resultados positivos dessa

\footnotetext{
${ }^{39}$ Termo utilizado para especificar a venda de produtos por catálogo nas residências dos consumidores.

${ }^{40}$ Termo utilizado para apresentar a modalidade de marketing que, através de um banco de dados, envia catálogos e material publicitário via correio. Hoje existe a modalidade de marketing direto via internet com o uso do e-mail marketing.
} 
tendência foram: a ampliação das discussões sobre os limites éticos das atividades de marketing, a implantação dos SAC - serviços de atendimento ao consumidor - e discussões sobre os direitos e deveres dos consumidores frente ao mercado consumidor e às práticas abusivas criadas por diferentes profissionais de mercado.

- Cybermarketing: o desenvolvimento das tecnologias digitais, a partir da década de 1980, proporcionou um avanço no contato direto com os consumidores, criando uma nova possibilidade de entender as relações e comportamentos de consumo. Os consumidores passaram a ser "ouvidos" com mais frequência, e suas opiniões comentários eram postados em redes sociais, blogs, chats, transformando-se em ferramentas estratégicas. Nunca antes em toda a história do pensamento em marketing e das relações de consumo, as necessidades e desejos dos consumidores se tornaram tão evidentes quanto, por exemplo, nos comentários sobre marcas e produtos nas redes sociais. A expressão que mais caracteriza essa perspectiva é "as redes sociais conectam pessoas".

- Marketing Social/Ambiental: a questão da responsabilidade social é um tema recente na área de Marketing. Ele começou a ser abordado pela área mercadológica na década de 1980, a partir do momento que a sociedade começou a "se mobilizar pressionando governo e empresas a solucionarem os problemas gerados pela industrialização" (Tenório, 2004, p. 17). $\mathrm{O}$ crescimento da industrialização proporcionou um aumento no consumo, mas uma diminuição na qualidade de vida, derivada do descontrole e da falta de fiscalização do descarte de produtos resultantes do processo produtivo, da poluição emitida pelas chaminés das fábricas, e do aumento do fluxo de pessoas que saíram das áreas rurais rumo às cidades, em busca de melhores condições de trabalho, geradas pela industrialização.

Até a década de 1950, o tema responsabilidade social estava atrelado a uma dimensão estritamente econômica, entendida como a capacidade da empresa de geração de lucros, criação de empregos, pagamento de impostos e das obrigações legais (Tenório, 2004, p.18). Foi a partir de 1950, com a sociedade pós-industrial, que o tema ganhou dimensões sociais e passou a ser discutido em termos de controle dos recursos renováveis, da escassez de recursos e dos problemas ambientais. As empresas passaram a assumir a responsabilidade de produzir com o objetivo de contribuir para o desenvolvimento das cidades e do país, priorizando, além do desenvolvimento humano e social, o ambiental. Em 1990, o debate sobre o tema responsabilidade social ganhou um novo conceito: a sustentabilidade. O desenvolvimento sustentável, composto pelas dimensões econômica, ambiental e empresarial, traz em si um 
sentido de valorização da vida e do planeta. Nessa perspectiva, os profissionais de marketing também assumiram a tarefa de conduzir campanhas e estratégias mercadológicas que valorizassem essa nova temática presente nas empresas e na sociedade.

- Marketing Experiencial/Experimental: essa tendência começou a ser utilizada nos anos 90, a partir das pesquisas do Prof. Bernd H. Schmitt ${ }^{41}$, psicólogo, que se dedicou aos estudos sobre psicologia do consumidor aplicados ao marketing. O termo "experiências de consumo" tornou-se a grande estratégia dessa perspectiva de marketing. A ideia era levar os consumidores a "experimentarem" a marca/produtos em diferentes situações. A expressão que mais caracteriza essa tendência é "as experiências são acontecimentos individuais" (Schmitt, 2002, p.74).

Essa perspectiva partia do princípio que as experiências de consumo poderiam ser planejadas através de um modelo estratégico chamado Módulos Experimentais Estratégicos (MEEs), criados a partir da observação e análise da dinâmica psicológica dos sentidos (paladar, olfato, visão, audição e tato), com o objetivo de causar "impacto sensorial" (Schmitt, 2002, p.78). Exemplos disso são embalagens que reforçam as características do produto através do uso de elementos visuais e sensoriais, por exemplo, a utilização de lacres e imagens que podem ser revestidas com películas que ao serem retiradas revelam um odor característico do produto em si.

Outro exemplo é a participação das empresas em eventos e causas sociais, levando também o consumidor a participar através de várias ações de mobilização popular com o patrocínio das marcas.

O Marketing experimental, quando foi lançado partiu da premissa que "as experiências são acontecimentos individuais que ocorrem como resposta a algum estímulo - por exemplo, os estímulos provocados pelas ações de marketing antes e depois da compra”. (Schmitt, 2002, p. 74). E completou: "as experiências geralmente não são espontâneas, mas induzidas" (Schmitt, 2002, p. 75).

\footnotetext{
41 O termo "Experiências de consumo" foi definido pelo Prof. Phd Bernd H. Schmitt como sendo a nova tendência do marketing no início do novo milênio. Para o professor, a atividade de marketing estaria deixando de trabalhar as relações com o mercado da forma tradicional, usando recursos ligados às definições de produto, preço, ponto de venda e propaganda, buscando uma interação maior com o consumidor através da valorização de sua experiência com a marca. Para isso, Schmitt, formado e pós-graduado em Psicologia, dedicou seus estudos à Psicologia do Consumidor e elaborou estudos específicos para desenvolver abordagens que envolviam os temas: experiência com a marca, gestão de experiência do cliente e geração de valor para o cliente.
}

Retirado do World Wide Web http://www4.gsb.columbia.edu/cbs-directory/departments/facultystaff/detail/494950/Bernd\%20Schmitt em 5 de junho de 2014. 
Como profissional de marketing, você fornece estímulos que resultam em experiências para o consumidor. Você escolhe os "provedores de experiências". Você é o encarregado. Dependendo do que você faz e de como faz, a sua empresa e a sua marca vão ser vistas como sendo mais simpáticas, admiradas e interessantes. Isso não significa que o cliente é passivo. Significa que você tem de tomar a iniciativa. É assim que o mundo funciona e é assim que ele foi incorporado como uma grande possibilidade de experiências.

No marketing contemporâneo, essa vertente das experiências de consumo, ao contrário da teoria de Schmitt (2002) (para a experiência acontecer deveria haver a motivação), já está sendo utilizada de forma diferenciada, congregando, além da necessidade de um contato mais próximo entre marcas e consumidores, a proposta de engajamento dos consumidores em tudo o que as empresas fabricantes se propuserem a realizar. A ideia de experiência remete a algo que supera a fidelização do produto, o contato através de canais de comunicação diretos e a comunicação boca-a-boca. Revela uma necessidade de identificar nos consumidores o que realmente faz sentido em termos de consumo. Propõe que o consumidor se torne "ativo" e "participativo" quando se vê exposto a uma campanha publicitária ou ação de marketing. Essa nova abordagem parece interagir mais com a ideia de que a pessoa e o consumidor podem fazer escolhas baseadas na sua experiência e necessidade de consumo.

Os profissionais de marketing contemporâneos, preocupados com o futuro das novas gerações e das influências das novas tecnologias, no comportamento dos consumidores, já propõem estudos $^{42}$ mais orientados para o entendimento do consumidor enquanto pessoa, buscando, talvez um sentido mais ético para as atividades que envolvem as relações de consumo. Autores americanos, como Philip Kotler, Hermawan Kartahaya e Iwan Setiawan (2010) definem essa nova fase como uma procura pelas "forças que estão definindo o novo marketing centrado no ser humano". Trata-se de um novo pensamento que reflete os problemas enfrentados pela atividade, que, durante décadas, negligenciou o papel do consumidor como pessoa e foi uma das responsáveis pelo movimento de estímulo ao consumo em todo o mundo, que hoje é extremamente questionado pela sociedade.

[...] Sempre que ocorrem mudanças no ambiente macroeconômico, o comportamento do consumidor muda o que provoca mudança no marketing. Ao longo dos últimos 60 anos, o marketing deixou de ser centrado no

\footnotetext{
${ }^{42}$ Destacam-se: Prahalad, 2009, com a obra A Riqueza na Base da Pirâmide, co-autor do livro Marketing 3.0 com Kotler, 2010; Porter, Michael E. e Kramer, Mark R. Strategy \& Society: The link between Comparative Advantage and Corporate Social Responsability, 2006, entre outros.
} 
produto e passou a ser centrado no consumidor. Hoje, vemos o marketing transformando-se mais uma vez, em resposta à nova dinâmica do meio. Vemos as empresas expandindo o foco dos produtos para os consumidores, e para as questões humanas. Marketing 3.0 é a fase na qual as empresas mudam da abordagem centrada no consumidor para a abordagem centrada no ser humano, e na qual a lucratividade tem como contrapeso a responsabilidade corporativa [...] (Kotler, Kartahaya e Setiawan, 2010, p.2).

Essa nova perspectiva pode sinalizar que a atividade do marketing está procurando evidenciar e criar estratégias mercadológicas que valorizem a questão da pessoa presente no consumidor. Isso pode sugerir que as empresas estão tentando repensar o seu verdadeiro papel social, econômico e ético na sociedade como um todo. Esse parece ser um caminho adequado ao desenvolvimento da atividade de marketing.

Diante da possibilidade de abordar o consumidor como pessoa na área do Marketing, e entendendo que esse pode ser um percurso que devemos apoiar para o desenvolvimento da área, partimos para um conhecimento mais aprofundado e claro sobre o que se entende como pessoa, por abordagens humanas, e também como esse conceito está sendo articulado à práxis do marketing.

Decidimos, então, ampliar a discussão sobre o conceito de consumidor no mundo contemporâneo, tendo em vista que outras abordagens e teorias, além da psicológica, poderiam contribuir para esse novo "olhar" com relação a tal conceito.

No próximo capítulo, vamos discutir essa nova possibilidade de conceito de consumidor, a partir das novas tendências do marketing e da proposta da Experiência elementar, de Luigi Giussani (1922-2005), presente na obra O Senso Religioso (2009), que discute a trajetória da experiência humana no impacto com a realidade, e que está sendo usada para propor diferentes abordagens em áreas distintas do conhecimento por diferentes profissionais, com destaque para as áreas da educação e da psicologia.

Para essa investigação, procuramos fundamentar esse estudo, primeiramente, a partir de um entendimento claro e aprofundado do que se entende por pessoa e experiência, através da história dos conceitos de pessoa e experiência. Posteriormente, descreveremos a abordagem da experiência elementar, e como ela pode se relacionar com a definição do conceito de consumidor, segundo as novas tendências do marketing contemporâneo, por meio da análise de alguns exemplos de campanhas publicitárias. 



\section{4 - A PESSOA, A EXPERIÊNCIA E A EXPERIÊNCIA ELEMENTAR.}

\section{1 - O conceito de pessoa na Idade Moderna e as implicações para o marketing contemporâneo.}

O limiar do século XX configurou-se como um período de grandes mudanças para a sociedade moderna nos campos da política, da cultura, da economia e dos relacionamentos humanos. As melhorias na qualidade de vida, fruto da revolução tecnológica, do avanço das ciências e das condições "materiais da existência" (Petrini, 2005, p.2), contribuíram de forma positiva para o dia a dia das pessoas, acelerando o desenvolvimento social, político e econômico. A chegada da Idade Moderna celebrou um momento importante e decisivo para o avanço da civilização.

O homem moderno passou a utilizar seu conhecimento com o objetivo de estimular o desenvolvimento de suas habilidades técnicas e científicas, inaugurando uma nova era de prosperidade. $\mathrm{O}$ avanço da civilização provocou mudanças estruturais em todas as esferas sociais através da modernização das cidades e da capacidade produtiva, contribuindo de forma significativa para que as necessidades humanas pudessem ser satisfeitas diante dos desafios do aumento populacional, da fome mundial, das economias de mercado, da padronização cultural, do avanço das epidemias e das ameaças de guerra.

Os "tempos modernos" inauguraram, também, um processo de desarticulação da mentalidade medieval unitária (Giussani, 2004, citado por Gaspar \& Mahfoud) refletindo a ansiedade e a necessidade do homem de libertar-se de modelos anteriores e de se posicionar frente aos desafios que se apresentavam de forma mais incisiva. "O centro do universo, antes atribuído ao divino, tornou-se o próprio homem que, voltado para si mesmo, considera o sucesso em sua dimensão específica da existência e seu ideal de vida [...]”. (Giussani, 2004 citado por Gaspar \& Mahfoud, 2006, p. 4).

Essa ruptura com o pensamento medieval e as contradições que permeavam o dia a dia das pessoas, os questionamentos sobre a existência e a relação com o mundo e a natureza foram temas de análise de pensadores e filósofos, que se dedicaram a discutir e a criticar essa nova forma de se relacionar com a vida.

Um desses pensadores foi Romano Guardini (1885-1968) ${ }^{43}$, filósofo e educador que dedicou parte de sua vida ao trabalho acadêmico e ao processo de formação de jovens na Alemanha. Guardini contribuiu, através de suas obras, para a interpretação crítica dessa nova mentalidade que se formava e as consequências que poderiam se instaurar a partir das

\footnotetext{
${ }^{43}$ Teólogo católico ítalo-alemão. Nasceu em Verona, na Itália, em 1885. Filho de um cônsul italiano. Com um ano apenas, se transferiu para a Alemanha. Estudante de química e de economia em Tubinga e em Berlim, cursou os estudos eclesiásticos e foi ordenado sacerdote. Foi professor de dogmática em Bonn (1922), de filosofia católica em Berlim (1923) e mestre na arte da interpretação; exerceu uma considerável influência na juventude católica alemã depois da I Guerra Mundial. Sua cátedra foi suprimida em 1939 pelo regime nacionalsocialista.
} 
reduções do pensamento moderno. De formação cristã, sua obra contemplou um diálogo importante com a cultura e a filosofia moderna, o que ampliou a possibilidade de sua leitura em outras áreas das ciências humanas, como a pedagogia e a literatura.

Brandão (2005, p. 21) ao analisar uma das obras desse autor, $O$ fim dos tempos modernos afirmou:

[...] Os tempos modernos são inaugurados por dois movimentos humanos: o impulso de conhecer a realidade por si mesmo, autonomamente, a partir da própria inteligência e o desejo de libertar-se dos modelos anteriores, já identificados como limitantes ou aprisionadores do pensamento. $\mathrm{O}$ indivíduo torna-se importante por si mesmo, sem qualquer referência exterior ou transcendente, contrapondo-se à Idade Média, para a qual o divino era o elemento primeiro, que fundamentava a concepção que o homem tinha de si e do mundo $[\ldots]$.

Ao assumir essa posição mais centrada em si mesmo, o homem, passou a vislumbrar novas responsabilidades tornando-se "importante para si próprio, para os outros homens, e para a época inteira" (Guardini, 1963, p. 19). O conceito de pessoa (denominada nesse período como sujeito) no mundo moderno entrou em conflito e oposição com as ideias medievais.

Na Idade Média, o conceito de sujeito encontra-se tão raramente como o de natureza. Sem dúvida que se conhecia a natureza como realidade e como norma. Também o homem da Idade Média via as coisas, a ordem da sua construção, a regularidade do seu comportamento, e chegou assim à representação de uma unidade suprema. Além disso, a Idade Média acolheu o conceito grego e, sobretudo aristotélico de natureza e trabalhou-o em todos os sentidos. Mas tal conceito não possuía o caráter acima descrito; tornou-se antes um meio de explicitar a criação das coisas por Deus [...]. Este caráter altera-se no declínio da Idade Média e, sobretudo no Renascimento. Impõese uma vivência do sujeito, que irá determinar toda a evolução ulterior. $\mathrm{O}$ homem descobre-se, de uma maneira nova, importante e interessante [...] (Guardini, 1963, p. 19).

Esse pensamento despertou nas pessoas responsabilidades e desafios que mudaram, de certa forma, o modo de convivência e os relacionamentos humanos. A concepção de homem, de cultura e de valores entrou em choque com os pensamentos anteriores, lançando o ser humano numa busca incessante por novas formas de convivência que enfrentassem essa nova realidade. 
Essas discussões também foram os temas centrais de uma obra do filósofo, intitulada $O$ mundo e a pessoa ${ }^{44}$. Trata-se de um conjunto de ensaios filosóficos sobre a essência do homem e sua relação com a natureza e o mundo. Em seu prefácio, Guardini (1963, p. 9) explicou que os três ensaios - a Pessoa, o Mundo e a Providência estavam unidos por uma análise sobre a forma como estava sendo conduzida a vida humana:

A essência do homem é o objeto dos ensaios que constituem o presente livro. Esta questão encontra hoje uma audiência que desde há muito não existia. No fundo, tenta-se verificar uma ideia: a de que o homem não é uma realidade opaca fechada sobre si mesma ou autossuficiente, nem uma forma dotada de um desenvolvimento autônomo, mas existe essencialmente em vista dum encontro.

É importante destacar o contexto histórico dessa obra do filósofo, escrita em 1939, logo após ter sido demitido da Universidade de Berlim por ordem de um comandante do $3^{\circ}$. Reich $^{45}$. Profundamente inconformado com essa atitude e com a atuação do poder nazista na Alemanha, Guardini escreveu os ensaios como uma espécie de resposta à situação específica em que se encontrava.

Na primeira parte da obra, o autor fez considerações sobre a natureza e a criação uma reflexão sobre a oposição do pensamento medieval e moderno, quanto aos temas relativos à visão de homem, natureza e cultura. Posteriormente, em outra parte da mesma obra, Guardini teceu considerações sobre o "ser pessoal", sua constituição, forma física, contato com a natureza e relação com os demais seres vivos.

Guardini (1963) apontou, nessa parte introdutória, três aspectos elementares para compreender a imagem do mundo formulada pelos tempos modernos: a natureza, o sujeitopersonalidade e a cultura. O conceito de natureza, antes apenas uma ideia relacionada ao divino, "um meio de explicitar a criação das coisas por Deus" (Guardini, 1963, p.19), passou a incluir o próprio ser humano como parte fundamental e importante da natureza, mas também capaz de explorá-la e de se apropriar dela: "Na medida em que o homem é uma realidade

\footnotetext{
${ }^{44}$ Do original alemão Welt und Person (1939). Para esse trabalho utilizamos a tradução brasileira de 1963, com o título "O mundo e a pessoa - Ensaio para uma doutrina cristã do homem".

${ }^{45}$ A chegada dos nazistas ao poder colocou fim à República de Weimar, uma democracia parlamentar estabelecida na Alemanha após a Primeira Guerra Mundial. Com a nomeação de Adolf Hitler como chanceler, em 30 de janeiro de 1933, a Alemanha nazista (também chamada de Terceiro Reich) rapidamente tornou-se um regime no qual os alemães não possuíam direitos básicos garantidos. Após um incêndio suspeito no Reichstag, o parlamento alemão, em 28 de fevereiro de 1933, o governo criou um decreto que suspendia os direitos civis constitucionais e declarou estado de emergência, durante o qual os decretos governamentais podiam ser executados sem aprovação parlamentar.Retirado do World Wide Web <http:// http://www.ushmm.org/wlc/ptbr/article.php?ModuleId=10005141/> em 26 de janeiro de 2014.
} 
corporal e psíquica, pertence também a esta natureza; mas na medida em que a considera e explora a apropria e lhe dá forma, opõe-se a ela".

O homem moderno passou a ser sujeito com personalidade, capaz de se desenvolver, se apropriar e criar. A personalidade representava um sentimento de primazia em relação aos demais seres vivos, tomada no sentido de ser única e capaz de responder as questões da realidade com objetividade, o que se tornou uma característica essencialmente humana:

É um novo sentimento que nasce pelo humano; um interesse pela sua diversidade; uma compreensão do que é autêntica e espontâneamente humano. Tal como a natureza, também a personalidade aparece como fato primeiro que não remete para mais atrás. Sobretudo, a grande personalidade traz em si a lei da sua própria existência. [...] O que até então era determinado pela espontaneidade do vivente reveste a sua expressão formal no conceito do "Sujeito". [...] É na filosofia de Kant que encontra a sua expressão mais clara. Quer se trate do sujeito lógico, ético, estético, trata-se sempre dum termo último sobre o qual repousa o mundo espiritual. É impossível remontar para além dele, pois tal tentativa só poderia ser efetuada com as categorias desta mesma subjetividade. O "sujeito" é a expressão lógica da "personalidade" (Guardini,1963, p. 20).

A ideia de personalidade criou "modelos" que passaram a ser valorizados pela genialidade do trabalho e desenvolvimento humanos, e que antes eram atribuídos à obra de Deus. "O homem torna-se senhor e árbitro de sua própria existência, não necessita e nem admite nenhuma referência ou fundamento exterior a ele" (Brandão, 2005, p. 23).

A obra criada pelo homem recebe uma nova significação, e também o homem como criador da obra. A obra do homem chama para si o sentido que, antes, estava deposto no mundo, obra de Deus. O mundo perde o caráter de criação e torna-se "natureza"; a obra do homem perde o aspecto de uma tarefa realizada por obediência a Deus e converte-se em "criação"; o próprio homem, anteriormente servidor e adorador, transforma-se em "criador". Tudo isso se exprime na palavra "cultura" (Brandão, 2005, p. 23).

Outro aspecto analisado por Guardini é a ideia de cultura da época moderna. Nesse conceito, "há uma reivindicação de autonomia. O homem procura diferenciar-se da existência para se modelar conforme a sua própria vontade" (Guardini, 1963, p. 23):

Na medida em que designa o mundo por "natureza", subtrai-o à mão de Deus e confere-lhe uma subsistência autônoma. Na medida em que se compreende como personalidade e como sujeito, separa-se do poder de Deus e torna-se senhor da sua própria existência. Pela vontade de cultura, empreende construir o mundo, não para obedecer a Deus, mas como sua obra própria [...]. Efetivamente, a formação do conceito de cultura coincide com a fundação da ciência moderna. 
Na segunda parte da mesma obra, dedicada ao conceito de pessoa, o autor explicita três níveis de análise sobre a "estrutura do ser pessoal", com o objetivo de "examinar o homem de forma concreta existindo como pessoa". As reflexões de Guardini parecem buscar um entendimento, de como o pensamento humano centrado em si mesmo poderia refletir na constituição das relações humanas e com os demais seres vivos.

O primeiro nível relaciona-se a "pessoa e forma":

Em primeiro lugar, "pessoa" significa tanto como "forma". Dizer que qualquer coisa é informada significa que os elementos que a constituem (matéria, forças, qualidades, atos, processos, relações) não se justapõem caoticamente, que, do mesmo modo, não são lançados exteriormente para formas, mas que, numa relação funcional e estrutural, entram num sistema de tal maneira que cada elemento só existe e pode ser compreendido pelo todo, tal como o todo só existe e pode ser compreendido a partir dos seus elementos (Guardini, 1963, p.137).

Nesse ponto o filósofo chama a atenção para a questão que o ser humano, como outras espécies vivas, se constitui a partir de elementos externos e, nesse sentido, não se distancia de outros seres.

O segundo nível de análise se relaciona com a "pessoa e a individualidade", em que o autor evidencia a relação do ser individual com seu centro e o mundo externo:

A "individualidade" é o vivente na medida em que se apresenta como uma unidade fechada do duplo ponto de vista estrutural e funcional. Por aí se destaca o vivente do conjunto das coisas em geral. Tem necessidade do mundo, dos seus materiais e energias, do mesmo modo que ele próprio forma uma parte deste conjunto de materiais e de energias; mas marca também os seus limites em relação a ele e defende-se contra as suas ameaças de absorção (Guardini, 1963, p. 139).

O indivíduo se torna único na medida em que possui características específicas que o diferem dos demais seres.

O terceiro nível de análise se apresenta como "pessoa e personalidade". A personalidade, tomada no seu sentido mais amplo, diferencia os homens entre si. As experiências humanas em sua vida diária e no seu trabalho se "encontram" com a "experiência originária" que cada ser humano traz consigo. Nesse ponto, Guardini ressaltou que a personalidade poderia estar presente em qualquer pessoa e indivíduo, independentemente de sua posição social, de suas relações de poder e de sua genialidade. 
A ideia de personalidade, proposta por Guardini, apresenta-se em oposição à ideia de “personalidade", do ser "famoso e conhecido", características do homem moderno.

Tal como foi elaborado pela Idade Moderna, o conceito de personalidade condensa uma síntese de quanto foi dito. Significa a forma viva fundamental do indivíduo humano por oposição a todos os outros. Esta forma une os elementos singulares que o constituem num dado momento, patenteando-os num todo; da mesma maneira, reúne os atos e os acontecimentos particulares do curso da sua vida numa forma onde está inscrita a unidade de um desenvolvimento e de um destino. O conceito em questão torna-se particularmente claro quando está em causa o grande homem, o gênio criador, tal como ele foi também nessa época perspectivado e desenvolvido; é um conceito subjacente a toda a visão moderna do homem (Guardini, 1963, p. 151).

A Primeira Guerra Mundial e, consequentemente, a Segunda Guerra quebraram de certa forma, o ideal da Idade Moderna, sintetizados no mito do eterno progresso e das grandes realizações. Após esses períodos, as relações humanas, sobretudo no continente europeu, sofreram profundamente com a insegurança, a falta de perspectivas futuras e as ameaças de outros conflitos mundiais.

Em síntese, Guardini apontou o avanço e as conquistas da humanidade nos tempos modernos, os progressos gerados pelo rigor da ciência, pela "precisão técnica e pelo espírito caracteristicamente moderno de conquista, organização e elaboração do mundo". Mas, ao mesmo tempo, chamou a atenção para os riscos dessa nova mentalidade, que concebeu um sujeito autônomo, capaz de dominar e se tornar uma espécie de "juiz de si mesmo", "atribuindo soberania à cultura, aos diversos ramos do saber" [...]. A "história referendou a gravidade e a magnitude desse risco, confirmando com os fatos a ingenuidade desse otimismo moderno" (Brandão, 2005, p. 26).

O homem moderno, em seu contato com a realidade, criou uma sociedade capaz de lidar com as necessidades humanas de moradia, de saúde, de educação, de cultura, de trabalho, entre outras, mas, em contrapartida, passou a desconsiderar os aspectos subjetivos nos relacionamentos diários e no ambiente familiar e profissional, provocando um sentimento de desamparo e abandono. Também, gerou uma sociedade que "abriu mão de sua originalidade e responsabilidade", sendo "passível de ser manipulada e conduzida à mercê dos interesses de quem está no poder":

O homem como esse, de modo nenhum, tem vontade de ser particular na sua estrutura original da condução da sua vida, nem mesmo de criar para si um ambiente que se refira completamente a ele e se possível só a ele. Ele aceita 
antes as coisas correntes e as formas de vida que lhe são impostas pela planificação racional e pelos produtos em série da máquina e de uma maneira geral aceita isso com a ideia de que tudo está certo assim: mesmo quando não tem vontade de viver segundo a sua própria iniciativa. A liberdade de movimento interior e exterior parece não ter para ele um valor fundamental. Insere-se com naturalidade na organização que dá a forma da massa e obedece ao programa de acordo com o dictum "o homem sem personalidade". O instinto desta estrutura do homem leva precisamente a não se distinguir enquanto indivíduo, mas a ficar anônimo - quase como se a autonomia constituísse a forma fundamental de toda injustiça e o princípio de todo o perigo (Guardini, 2000, p. 55 citado por Brandão, 2006, p. 7, itálico e aspas do autor).

A sociedade contemporânea capitalista se consolidou nesse momento de desconstrução do passado medieval, criando possibilidades para o futuro, pautando-se na satisfação das necessidades no presente. O "homem das massas", segundo Guardini (2000, p.55 citado por Brandão, 2006, p. 7) foi "levado a abrir mão de sua originalidade e responsabilidade no modo de conduzir a vida, aceitando o que lhe é proposto ou imposto exteriormente". "Essa atitude é fruto da normatização de comportamentos, verificada quando se reduz o homem a um mero número, passível de ser manipulado e conduzido à mercê dos interesses de quem está no poder" (Brandão, 2006, p. 6). No contexto das massas e das sociedades contemporâneas, os indivíduos perdem as suas características pessoais e passam a ser parte de um universo mais amplo com características e necessidades mais padronizadas.

Esse descompasso criado pela contemporaneidade coloca o homem numa situação paradoxal em seu ambiente: ao mesmo tempo em que se desvenda um mundo fascinante, gera-se uma situação ameaçadora para o próprio homem: "o homem se encontra livre para se movimentar, mas sem morada no mundo".

[...] A angústia da Idade Moderna é devida em grande parte ao sentimento de não ter nem um lugar simbólico, nem um refúgio que seja imediatamente convincente; e também da experiência sempre renovada de não encontrar no mundo um lugar para existência e que satisfaça a sua necessidade de sentido (Guardini, 2000, p. 37, citado por Brandão, 2006, p. 5).

As pessoas passaram a conviver com uma crise de valores, sobretudo humanos. $\mathrm{O}$ grande paradigma desse momento é que apesar da humanidade ter alcançado um avanço significativo em todos os setores e atividades relacionados à sua existência, o uso da razão, antes porta-voz das grandes descobertas do século XX, passou a ter um papel coadjuvante na construção da sociedade pós-moderna. A racionalidade do homem ficou presa mais à necessidade de tornar os relacionamentos humanos consequências de padrões de 
comportamento ditados pelas regras de mercado. A cultura do efêmero ${ }^{46}$, do descartável, da futilidade, da individualidade, do desrespeito à integridade física e dos valores culturais passaram a ser valorizados pela sociedade de consumo.

Após a efervescência do início do século XX, nas décadas posteriores à Segunda Guerra Mundial, surgiu uma sociedade capitalista contemporânea com o propósito de oferecer produtos que assegurassem um modus vivendi de conforto, bem estar e prosperidade. $\mathrm{O}$ avanço capitalista supervalorizou as sociedades de consumo, favoreceu as atividades de marketing, porém, também, deu início ao processo de melhoria da qualidade de vida de centenas de pessoas que viviam em países em desenvolvimento. Bons exemplos foram o desenvolvimento nos países orientais, Índia e China, no Brasil, Indonésia e em algumas economias em expansão na África.

Inaugurou-se a época da supervalorização do consumo em detrimento das relações sociais como uma forma de preencher "os vazios" decorrentes da necessidade de produzir e consumir cada vez mais. O dinamismo do consumo estimula a população mundial, sobretudo dos países mais ricos, a se tornar cada vez mais soberana e totalitária contaminando os relacionamentos humanos em diferentes faixas etárias.

A experiência do homem, na sociedade de consumo, retomada a partir da reflexão de Guardini (1963) e, na perspectiva da sociedade moderna, sofreu com essa desvalorização das exigências elementares de liberdade, de justiça, de beleza e de verdade, próprias do dinamismo humano nos relacionamentos diários.

A cultura, como manifestação do ser humano, também sofreu com o avanço da civilização que destruiu e corrompeu a história e a memória das pessoas na modernidade. Essa cultura dominante parece "ignorar" as exigências elementares do ser humano, tentando incutir uma forma de sociedade pautada em padrões de comportamento e de consumo.

Essa mesma sociedade concentra-se nas expectativas do futuro, planejando e estabelecendo metas a longo e médio prazos para o aumento do consumo e da expectativa de vida das pessoas. Contudo, parece ter se esquecido de que o presente e as relações cotidianas também constituem uma "vida tensa de significados" (Mahfoud \& Massimi, 2012, p. 65).

Na ânsia por trilhar um próprio caminho, o sujeito tende a incluir o futuro em suas elaborações da experiência, mas essa experiência pede também a inclusão do passado. Sem ancoragem na memória coletiva e na história, seria impossível a elaboração da experiência, e o sujeito tenderia a permanecer no

\footnotetext{
${ }^{46}$ Termo utilizado por Lipovetsky (2004b, citado por Petrini, 2005, p. 6).
} 
campo das reações ou idealizações que, também elas, dispersariam a força de significado do presente (Mahfoud \& Massimi, 2012, p. 65).

As reflexões sobre o conceito de pessoa apresentadas por Guardini (1963) e a realidade que se apresentou ao homem moderno, foram fundamentais para a aproximação desses temas ao conceito de consumidor estabelecido na sociedade moderna, uma vez que se pode observar que a conceituação do tema é favorável à realidade do mercado.

$\mathrm{Na}$ área do marketing, o consumidor ainda está atrelado à ideia de "massa", apesar dos avanços tecnológicos que possibilitam um contato mais próximo com a grande maioria do público-alvo. A tentativa de "individualizar" o contato com o público e fidelizar clientes, no sentido de torná-los únicos, tem acontecido, mas para algumas categorias de produto, esbarra na relação custo-benefício e nas exigências de mercado. Essa aproximação com o consumidor final, oferecendo um produto que possa atender as suas necessidades, é mais evidente no mercado de marcas de luxo, destinado aos consumidores com maiores rendas.

O movimento da globalização, a internet e as redes sociais possibilitaram um fluxo maior de informações, criando uma malha de contatos que vai de um extremo ao outro do planeta. Porém, em termos de consumo, os jovens, por exemplo, que vivem em países com culturas, economias e climas diferentes, consomem as mesmas bebidas, os mesmos refrigerantes, usam as mesmas calças jeans e os mesmos tênis, tornando o consumo de determinados produtos e marcas global e único. A padronização ainda é uma regra da economia capitalista.

$\mathrm{Na}$ área de Marketing existe um movimento entre os profissionais e acadêmicos de se buscar novas definições para o conceito de consumidor, fruto da necessidade de se criar uma sintonia maior com o mercado, buscando respostas para o sentido de "experiência" e consumo. As tentativas esbarram nas questões mercadológicas, sociais e econômicas. Entretanto, a sensação é de que uma mudança de comportamento diante das necessidades de consumo deve ser assumida, e isso passa não só pela tomada de consciência dos consumidores, mas por uma nova abordagem da atividade de marketing e, ainda por uma mudança na formação dos profissionais dessa área.

Na sequência, será analisado o percurso histórico do conceito de experiência e sua relação com a psicologia e a atividade de marketing. Os dois conceitos - pessoa e experiência são fundamentais para as conclusões acerda da discussão sobre a abordagem da Experiência elementar, o conceito de consumidor no mundo contemporâneo, assim como as novas tendências do Marketing, temas centrais dessa dissertação. 


\section{2 - O conceito de experiência - breve contexto histórico}

O conceito de "experiência" na atualidade, passa também, por uma mudança de sentido, na medida em que é usado apenas para relatar experimentos, contatos e atividades diárias.

As definições de "experiência" tem raízes históricas e sofreram, na cultura ocidental, "uma incontrolável deteriorização semântica" 47 , descaracterizando a sua fundamentação filosófica e simplificando o seu uso apenas como parte de um conteúdo emocional, "o que reduz a um nível naturalista e imediatista, eliminando o sujeito ativo do processo" (Gaspar \& Mahfoud, 2006, p. 2).

Molioni (1992, citado por Massimi \& Mahfoud, 2007, p. 27) explica que "no contexto hodierno, encontram-se algumas reduções da concepção de experiência que por sua vez fundamentam-se em alicerces teóricos propostos pelas filosofias modernas e contemporâneas".

Por diferentes autores, a experiência é reduzida a um significado emocional como algo que se adverte imediatamente e de modo espontâneo (Massimi \& Mahfoud, 2007). Em outras situações, a experiência é concebida como "experimentalismo", como um experimento científico em que "provar" significa comprovar a sua existência. Os mesmos autores afirmam que, nesse sentido, "o real identifica-se com o que é passível de ser testado pela experimentação, não podendo ser aí incluídos valores ou relacionamentos pessoais (a menos que o sujeito se submeta a eles), de modo que a experiência é tomada como um "provar" sem razões"( Massimi \& Mahfoud, 2007, p. 17).

Ao retomar esse conceito numa dimensão histórica, compreende-se a importância de seu entendimento, principalmente para autores como W. Wundt (1900) e W. James (1989), que "utilizaram conceitos de experiência baseados na filosofia empirista e nos postulados das ciências naturais" (Massimi \& Mahfoud, 2007, p. 17), e fundamentaram os pressupostos da ciência da psicologia moderna.

Nesse sentido faz-se necessária uma análise do conceito de experiência segundo essa dimensão histórica, para que se possa estabelecer um paralelo com a abordagem da experiência elementar, proposta por Luigi Giussani (1922-2005), em sua obra O Senso Religioso (2009), que será parte das discussões deste capítulo.

Para realizar tal percurso histórico, utilizamos os trabalhos de Massimi e Mahfoud (2007), Mahfoud e Massimi (2008), e Gaspar e Mahfoud (2006), que pesquisaram as

\footnotetext{
${ }^{47}$ Lima Vaz (2000 citado por Gaspar e Mahfoud, 2006).
} 
contribuições de autores da Antiguidade, Idade Média, Moderna e Contemporânea, os quais, através de suas reflexões, ampliaram o conceito dentro da perspectiva filosófica e psicológica, bem como suas implicações.

$\mathrm{Na}$ constituição da história dos Saberes Psicológicos ${ }^{48}$, o tema da "experiência" foi essencial para se compreender os elementos fundamentais da natureza humana. Aristóteles (384 a.C. 1322 a.C.) discutiu essa temática como sendo uma necessidade humana para aquisição do conhecimento. Massimi e Mahfoud (2007) retomaram a abordagem do filósofo ao analisarem o primeiro capítulo do primeiro livro da obra Metafísica (Aristóteles, século IV a. C./1969, citado por Massimi \& Mahfoud, 2007):

A experiência é uma etapa da aquisição do conhecimento: várias lembranças de uma mesma coisa chegam a constituir a experiência, independentemente de sua veracidade que poderia vir a ser verificada pelo intelecto (Massimi \& Mahfoud, 2007, p. 17).

O dinamismo psíquico de elaboração da experiência foi apresentado pelo filósofo em diferentes obras. Massimi e Mahfoud (2007, p. 18, itálicos dos autores) apresentaram o percurso do pensamento do filósofo:

Em Analíticos posteriores (II, 19, 100 a 4) (citado por Abbagnano, 2003), o estagirita ${ }^{49}$ afirma que, a partir da sensação, desenvolve-se o que chamamos de recordação, cuja repetição possibilita a experiência. Por isso, recordações quantitativamente significativas constituem a experiência como um conceito universal fixado na alma nos termos de uma unidade que transcende a multiplicidade: é única e idêntica [...]. Na obra Parva Naturalia (Aristóteles, século IV a. C./1993), afirma que os objetos presentes no mundo produzem impressões no corpo através do órgão de sentido, e impressões na alma - a sensação como uma espécie de pintura conservada na memória. "Potência comum a todos os animais, a memória preserva os vestígios da sensação vivenciada" [...]. No De Anima (Aristóteles, século IV a. C./2001), ao descrever as propriedades psíquicas, coloca a potência da imaginação como intermediária entre a percepção e o pensamento, "implicando sempre a presença da percepção e, além disto, encontrando-se ela própria implícita no ato de julgar”. (p. 97)[...]. Da memória e da imaginação elabora-se então a experiência que por sua vez dá origem às artes e às ciências [...]. [...] do ponto de vista semântico, Aristóteles, ao denominar experiência, utiliza de três palavras gregas diferentes: aisthesis - a saber, sensação, sentimento e intuição - empeiria - a saber, experiência no sentido de habilidade e pratica - e peira - ou seja, prova e experimento (Fabris, 1997). Tal diversidade de

\footnotetext{
48 "Sob o rótulo de História da Psicologia compreendem-se dois domínios distintos, o da História dos Saberes Psicológicos e o da História da Psicologia Científica: o primeiro utiliza-se dos métodos próprios da História Cultural e da História Social, o segundo assume as modalidades de investigação sugeridas pela Historiografia das Ciências (Massimi, 2010, p.100)".

49 Aquele nascido em Estagira, cidade da antiga Grécia, conhecida por ter sido a cidade natal do filósofo Aristóteles.
} 
termos indica a complexidade da concepção aristotélica de experiência alertando para um necessário cuidado com o risco da simplificação.

O pensamento aristotélico reflete a cultura grega clássica e oferece, no contexto da elaboração do conhecimento, a partir da experiência, importante contribuição que envolve desde a "percepção, passando pelas potências psíquicas da recordação (memória), da imaginação, do pensamento e do 'senso comum'". ${ }^{50}$ (Gaspar \& Mahfoud, 2006, p. 3). É a partir da experiência que se obtém o conhecimento. "Com efeito, a experiência serve ao homem para atestar que certo fato ocorreu, mas não para definir o motivo de seu acontecer" (Massimi \& Mahfoud, 2007, p. 18).

Na Idade Média, o pensamento estava atrelado a uma "mentalidade unitária" do real, a partir da consolidação de significados relacionados a Deus. A base do conhecimento era a sustentação da fé cristã, e a partir desse suporte teológico é que o homem tinha a capacidade de vivenciar as suas experiências. Giussani (2004, citado por Gaspar \& Mahfoud, 2006, p. 3) esclareceu essa dependência do homem a Deus:

Com efeito, a cultura medieval favorecia a formação de uma mentalidade marcada por uma religiosidade autêntica determinada por uma imagem de Deus como horizonte abrangente de toda e qualquer ação humana, por uma concepção de Deus como pertinente a todos os aspectos da vida, [...] como ideal unificante.

Na obra de Santo Agostinho (386/ 1998), Solilóquios ${ }^{51}$ o ponto de partida para a revelação da experiência e o "conhecimento sensorial" estava atrelado a uma complexa relação com Deus:

[...] as coisas são iluminadas pelo sol para que possam ser vistas, assim, como o é a terra e tudo o que é terreno; mas Deus é quem ilumina. Assim, eu, a razão está nas mentes como a visão nos olhos, como tampouco olhar e ver. Por isso, a alma precisa de três coisas: ter olhos dos quais possa usar bem, olhar e ver. O olhar da alma é a mente isenta de toda mancha do corpo, isto é, já afastada e limpa dos desejos das coisas mortais, o que somente a fé, em primeiro lugar, lhe pode proporcionar.

No tratado A Trindade (399-422/2000, livro IV, capítulo 20, citado por Massimi \& Mahfoud, 2007, p. 19), Agostinho, seguindo a tradição medieval revelou o conceito de

\footnotetext{
${ }^{50} \mathrm{O}$ "senso comum" se refere à capacidade geral de sentir à qual é atribuída a função de constituir a consciência da sensação (ou seja, de "sentir o sentir") e de perceber as determinações sensíveis comuns aos vários sentidos (citado por Gaspar \& Mahfoud, 2006).

${ }^{51}$ Citado por Massimi \& Mahfoud, 2007, p. 18.
} 
experiência em relação a Deus e o classificou como "verbo de Deus". O verbo, nesse sentido, significava "conhecimento experiencial (no sentido de "ciência saborosa, ou seja, de um entendimento que envolve também a sensação e o afeto")". Percorrendo os capítulos IV e VI da mesma obra, o autor dedicou ao tema do conhecimento uma referência ao "conhecimento da alma por si mesma", como se "o conhecimento pessoal da própria experiência acarreta a certeza moral". No capítulo quarto do livro décimo do tratado, "sustenta que a alma procura conhecer racionalmente a si mesma, já sabe ser alma e pelo conhecimento intelectual busca completar este seu conhecimento intuitivo dado pela experiência":

Quando a alma procura conhecer-se, já sabe que é alma; caso contrário ignoraria se procura a si mesma e correria o risco de procurar uma coisa por outra. [...] Como sabe que ainda não se encontrou toda, ela sabe qual é a sua grandeza. E assim busca o que lhe falta a seu conhecimento (Agostinho, 2000, p. 318-319, citado por Massimi \& Mahfoud, 2007, p. 20).

Tomás de Aquino (1225-1274), seguindo a tradição de Agostinho, retomou o "conhecimento experiencial de Deus, afirmando que se tratava de um "conhecimento saboroso" (Suma, I, qu. 43, 5,3, citado por Massimi \& Mahfoud, 2007, p. 20), guiado pelo amor" e ampliou esse pensamento, incluindo não só os sentidos externos ligados aos órgãos sensoriais, mas também, aos "quatro sentidos internos: fantasia, cogitativa, memória e senso comum." 52

$\mathrm{O}$ avanço das ciências, a necessidade de se conquistar um maior bem-estar para a sociedade contribuiu para o avanço da valorização da razão humana.

\begin{abstract}
A noção de experiência unitária e complexa fragmentou-se numa multiplicidade sem um eixo organizador que considerasse a totalidade do ser no mundo. Com isso, o centro do universo tornou-se o próprio homem que, voltado para si mesmo, considera o sucesso em uma dimensão específica da existência o seu ideal de vida, não importando qual seja tal dimensão ou os meios utilizados para alcançar esse sucesso. Nesse sentido, o Humanismo forneceu o suporte cultural ao "perfil de uma unidade em via de desagregação" (Gaspar \& Mahfoud, 2006, p. 4).
\end{abstract}

Nesse contexto surgiram os autores precursores da ciência moderna, como "Galileu e sua interpretação matematizante da natureza, Hobbes e sua doutrina da subjetividade segundo o qual os fenômenos existiriam apenas nos sujeitos e Descartes e sua dúvida metódica que coloca a razão, e não a realidade como fonte de certeza” (Gaspar \& Mahfoud, 2006, p. 4).

\footnotetext{
${ }^{52}$ Op. cit. em Massimi \& Mahfoud, 2007 e retomados por Gaspar \& Mahfoud, 2006.
} 
O termo "experiência" para Massimi e Mahfoud (2007, p. 23) passou a "designar a concepção do real que o homem elaborava através dos métodos de conhecimento escolhidos para tanto, dentre os quais, o mais fidedigno é o conhecimento científico".

O filósofo inglês David Hume (1711-1776), seguidor do pensamento empirista, propôs examinar a experiência com "espírito de exatidão e do raciocínio" (1972, p. 13, citado por Massimi \& Mahfoud, 2007, p. 23). Segundo Hume:

[...] a existência de qualquer ser somente pode ser provada mediante argumentos derivados de sua causa ou de seu efeito, e estes argumentos se fundam inteiramente na experiência. [...] se raciocinarmos a priori, qualquer coisa pode parecer capaz de produzir qualquer coisa. A queda do seixo pode, pelo que sabemos, extinguir o sol, ou a vontade de um homem controlar os planetas e suas órbitas. [...] é unicamente a experiência que nos ensina a natureza e os limites da causa e do efeito, e permite-nos inferir a existência de um objeto partindo de um outro (1972, p. 13, citado por Massimi \& Mahfoud, 2007, p. 23).

A posição de Hume enfatizava o movimento empirista e, posteriormente, a filosofia positivista de A. Comte e H. Spencer, para "os quais a ciência é o único saber que permite apreender a experiência de modo unificado" (Massimi \& Mahfoud, 2007, p. 23).

Os movimentos científicos fomentaram os estudos de diferentes áreas do conhecimento e, nesse contexto, surgiu a Psicologia Moderna, como uma área que definitivamente se separava da tradição filosófica e da fisiologia. Os processos psicológicos passaram a ser medidos e testados em laboratórios a partir dos pressupostos empiristas e positivistas. Os autores que se destacaram nesse período foram Wundt (considerado o pai da Psicologia Moderna) e James, nas universidades da Alemanha e dos Estados Unidos, respectivamente.

[...] a concepção wundtiana de experiência elimina de sua gênese a relação entre sujeito e objeto do conhecimento procurando superar a visão da Psicologia filosófica tradicional em que a relação sujeito-objeto acarreta a presença do sujeito ativo na elaboração da experiência [...] (Massimi \& Mahfoud, 2007, p. 10).

Ao assumir esse caráter experimental e científico, a partir da instauração da Psicologia Moderna, as demais abordagens psicológicas, que floresceram no início do século XX, foram influenciadas em sua concepção e fundamentação, o que provocou uma "postura reducionista" na forma de conceber o ser humano no contexto das ciências psicológicas e 
comportamentais. O reflexo desse pensamento está explícito na atualidade em diferentes concepções e abordagens psicológicas e no trabalho psicológico:

\begin{abstract}
Nisso, há uma forte crítica à maneira com a qual temos feito Psicologia, porque frequentemente privilegiamos modelos de homem a ele mesmo; fixamo-nos em um aspecto preferido, definindo todo o homem por aquele aspecto que mais gostamos, ou que nos interessa ideologicamente afirmar. Assim , a abertura para a totalidade se perde, comprometendo o resultado do conhecimento científico; ao mesmo tempo que a exigência de realização se confunde, comprometendo o dinamismo propriamente humano tanto da pessoa atendida quanto do psicólogo (Mahfoud, 2012, p. 30).
\end{abstract}

Ainda nesse percurso histórico, as contribuições da fenomenologia ${ }^{53}$ para a discussão do conceito de experiência na psicologia contemporânea foram fundamentais para o resgate da dimensão da subjetividade do conceito:

$\mathrm{Na}$ medida em que as ciências do espírito e, particularmente, a psicologia científica, nascida no século XIX a partir do modelo das ciências naturais, começam a questionar a adequação de tal modelo ao seu objeto próprio, a fenomenologia mostra-se uma fértil alternativa para a estruturação de uma abordagem mais apropriada ao estudo do homem. A influência da fenomenologia no campo das ciências humanas é bastante vasta e heterogênea, incluindo disciplinas como a história, a sociologia, o direito, a antropologia e a psicologia. De um modo geral, a grande contribuição da fenomenologia a essas ciências é a de fornecer um modelo de descrição e compreensão de sentido próprio para a abordagem dos fenômenos que dizem respeito ao espírito, ao contrário do modelo de "explicação causal" empregado pelas ciências da natureza (Sá, 2007 citado por Jacó-Vilela, Ferreira \& Portugal, 2007, p. 321).

A fenomenologia de Husserl "contrária à direção que ele criticava (psicologia científica), enfatizava a prioridade da intuição sobre o pensamento conceitual", [...] o procedimento intuitivo é considerado como o elemento essencial da atitude filosófica (Sá, 2007 citado por Jacó-Vilela, Ferreira \& Portugal, 2007, p. 321).

O valor da experiência foi redescoberto pela fenomenologia "na qual se identifica tanto um nível passivo do sujeito que sofre impacto da presença no mundo, quanto um nível caracterizado pela presença ativa do sujeito, que elabora tal impacto buscando apreender a presença no mundo" (Gaspar \& Mahfoud, 2006, p. 6).

\footnotetext{
${ }^{53}$ O pensamento de Edmund Husserl (1859-1938) deu origem a uma das mais férteis correntes da filosofia moderna, a fenomenologia. Essa corrente influenciou decisivamente o movimento filosófico e cultural que se propagou na Europa após o fim da Segunda Guerra Mundial, conhecido como existencialismo. Fenomenologia e existencialismo, em suas convergências, tensões e entrecruzamentos, constituem juntos uma das importantes matrizes filosóficas das psicologias do século XX. (Jacó-Vilela, Ferreira \& Portugal, 2007, p. 319).
} 
A ciência psicológica procura apreender o que é propriamente essencial do $e u$ em ação no mundo-da-vida da qual têm consciência. Ela "compreende todo o mundo espiritual, tematiza todas as pessoas e seus gêneros, todas as operações pessoais em suas formações culturais" (Gaspar \& Mahfoud, 2006, p. 6).

Husserl, em sua obra "Crise das ciências europeias e a fenomenologia transcendental" (1954/2002), criticou a psicologia moderna, e considerou que ela fracassou, pois não realizou a indagação acerca da subjetividade concreta e plena "[...] a reflexão radical e livre de preconceitos, que abriria necessariamente à dimensão transcendental subjetiva” (Husserl, 2002, p. 235, citado por Mahfoud \& Massimi, 2008, p. 57).

O reconhecimento de que algo deveria ser superado pelas abordagens científicas da psicologia e das ciências do comportamento humano, permeou a obra de Husserl e de outros fenomenólogos, discípulos desse autor como a filósofa Edith Stein (1891-1942). Na experiência, na vivência, no dia a dia das pessoas são encontradas "realidades mistas" ${ }^{54}$, que exigem do psicólogo diferentes modalidades de abordagem e o reconhecimento da subjetividade que permeia o sentido atribuído ao conceito de experiência.

O conceito de experiência fundamentado na fenomenologia de Husserl contribuiu para uma nova forma de abordar e retomar a subjetividade humana e o mundo real.

\section{3 - O conceito de experiência para a área do Marketing e sua relação com o conceito de experiência na Psicologia, e o conceito de Experiência elementar.}

No caso específico da área de Marketing e das relações de consumo, o conceito de experiência, utilizado no final dos anos 90, se referia aos termos "experiências de consumo" ou "experiências com a marca". A ideia de experiência nesse contexto remete a “acontecimentos individuais que ocorrem como resposta a algum estímulo" (Schmitt, 1999, p. 74). De acordo com esse autor, os profissionais de marketing devem "apontar o ambiente e o cenário certos para que as experiências pelas quais o cliente queira passar possam acontecer" (Schmitt, 1999, p. 75).

\footnotetext{
${ }^{54}$ Interpretação de Mahfoud \& Massimi (2008, p. 59), a partir do trecho "a vida espiritual se apresenta como processo psíquico; tudo o que é psíquico nos aparece ligado com o ser material; as formações espirituais objetivas, por sua vez, nos aparecem como fundamentadas no ser da natureza. Por outro lado, todo ser natural pode se tornar portador de um sentido espiritual. Por isso não nos maravilhemos se nas ciências empíricas orientadas para os objetos da experiência - se entrelaçam métodos diversos a serem diferenciados" (Stein, 1922/1999).
} 
Para conceituar a ideia de "experiências de consumo" como parte das estratégias e práticas de marketing, Schmitt (1999) partiu da análise de fatores neurobiológicos, psicológicos e comportamentais dos consumidores. "A ideia de que existem áreas funcionais distintas do cérebro, que correspondem a experiências distintas, foi chamada de visão modular da mente". (Schmitt, 1999, p.76). O mesmo autor, explicou essa relação entre os três fatores analisados:

Em primeiro lugar, existe um sistema perceptivo ou sensorial localizado no tálamo. Esse sistema processa os dados sensoriais sob a forma de pequenas ondas de luz, ondas de som, informações sensoriais e táteis que atingem a retina, o ouvido e outros sensores. Depois temos o sistema emocional, localizado em duas partes separadas: no sistema límbico e numa região próxima chamada amígdala produzem um rápido impulso, uma resposta sem muito raciocínio e análise, ao passo que o neocortex pode produzir emoções mais complexas. Finalmente, há outras partes do neocortex que são sede da cognição, do pensamento e da criatividade" (Schmitt, 1999, p.76).

Esses três sistemas - sensação, cognição e percepção, tem estruturas próprias, porém, quando estimulados, "interagem para gerar a percepção sensorial, sentimentos e pensamentos coerentes". Os profissionais de marketing oferecem "estímulos" para a compra e a propagação de diferentes ideias, produtos e serviços. Esse estímulo é induzido na medida em que "oferece as experiências que os consumidores mais esperam e desejam”. Isso não é por acaso, mas sim resultado das pesquisas de mercado e comportamento dos consumidores.

Um exemplo dessa prática pode ser observado nas estratégias para desenvolvimento de novos produtos, como parte da atividade de marketing. A escolha do nome, da logomarca e do design dos produtos pode iniciar um processo de experiência de consumo. Ao criar um produto voltado para o consumidor feminino, por exemplo, um depilador eletrônico, “o design pode passar a ideia de feminilidade em diversos níveis: no formato que pode lembrar a anatomia feminina, e a sutil gama de cores que faz lembrar as pétalas de uma tulipa" (Schmitt, 1999, p. 95). O nome do produto e o slogan que farão parte da comunicação também devem carregar essa relação com a feminilidade. A comunicação através da campanha publicitária se encarrega de intensificar e marcar esses apelos, levando os consumidores a experimentarem o produto. Além da ênfase no design, outros fatores como: a ambientação das lojas, o patrocínio a eventos culturais e esportivos, a comunicação através do meio virtual e as pessoas envolvidas nas estratégias mercadológicas, como vendedores, representantes das empresas, prestadores de serviço e qualquer outra pessoa que tenha ligação com a empresa e a marca, podem ser classificados como "provedores de experiência". 
Essa forma de conceber o conceito de experiência, na área de Marketing, se assemelha, num certo sentido, ao conceito empirista de experiência, em que o sujeito se torna passivo diante dos estímulos. Essa visão estava presente no conceito de experiência protagonizado pelos fundadores da psicologia moderna, entre eles o médico e filósofo alemão W. Wundt (1832-1920).

[...] Wundt propõe a unidade metodológica entre ciências naturais e psicologia, de modo que os métodos da psicologia experimental possam ser concebidos como análogos aos das ciências naturais. O mesmo valeria para as ciências do espírito. A psicologia - como ciência da experiência imediata - é a ciência empírica, reintegrando as ciências naturais ao seu contexto originário dado antes das operações de abstração. [...] Em suma, no processo de fundação da psicologia moderna, a concepção wundtiana de experiência elimina de sua gênese a relação entre sujeito e objeto do conhecimento procurando superar a visão da psicologia filosófica tradicional em que a relação sujeito objeto acarreta a presença do sujeito ativo na elaboração da experiência (processada pelas suas potências psíquicas a partir da simples recepção da sensação pelo mundo externo) (Massimi \& Mahfoud, 2007, p. 25).

O conceito de experiência elementar se relaciona à compreensão do ser humano de uma forma mais completa. A partir das experiências diárias e do contato com a realidade, surgem os questionamentos e relacionamentos. Diante da realidade, o ser humano, também possui exigências próprias que são consolidadas a partir de seu convívio com a sociedade, com a família e as tradições, e se relaciona com tudo que existe a sua volta.

O conceito de experiência elementar parece resgatar a "visão da psicologia filosófica tradicional", e potencializa a relação do "sujeito objeto" a partir de sua "presença ativa na elaboração da experiência". O conceito de experiência, nesse contexto, une conhecimento e vida psíquica de uma forma mais completa e fundamentada.

Bernareggi (2007, p. 1) ao apresentar a fundamentação filosófica da experiência elementar, numa palestra proferida no Departamento de Psicologia da Faculdade de Filosofia e Ciências Humanas da UFMG - Minas Gerais, na abertura de um curso sobre experiência elementar, enfatizou a importância do conceito de experiência original, que "nos acompanha, nos fundamenta, nos sustenta, nos motiva sempre, constantemente". E esclarece: "Existe um núcleo fundamental de experiência que representa a continuidade de nossa pessoa e justifica o fato de que nós somos uma pessoa, não somos um conjunto de ações e reações [...]”. Mahfoud (2012, p. 111), completou: 
Interessa-nos reconhecer o que somos, o que o ser humano é: eis o ponto central. Não estamos buscando, aqui, elaborar um modelo de homem ou um modo de ver que nos agrade. Estamos buscando reconhecer algo que somos, profundamente, porque nos interessa a nossa realização enquanto pessoa. Por isso buscamos aprender e reconhecer os elementos essenciais do nosso ser, aprender e reconhecer que somos exigência de felicidade, que somos exigência de realização. Assim, reconhecemos nossa exigência de conhecimento não como um setor da vida, mas como resposta a uma provocação do mundo em nós, resposta necessária porque sem ela não seremos nós mesmos.

O conceito de consumidor no marketing contemporâneo pode ter sido influenciado pela aproximação entre as áreas de Marketing e Psicologia, sobretudo a partir das pesquisas experimentais que contribuíram para os estudos de psicologia e comportamento do consumidor. Porém, diante das mudanças no comportamento do consumidor, que tem se tornado mais "crítico" frente às abordagens de mercado, que "induzem" o consumo de diferentes produtos e serviços, a área de Marketing tem direcionado seus esforços para relacionar-se com os diferentes públicos de uma forma mais "humana".

Esses esforços favorecem o surgimento de ações que contribuem para intensificar um contato mais próximo com o consumidor final, a partir da utilização, por exemplo, de estratégias voltadas ao engajamento com a marca. As estratégias mercadológicas, segundo essa perspectiva, se tornam mais próximas do consumidor, na divulgação e desenvolvimento da marca e do produto.

Ao analisarmos os conceitos de pessoa, experiência e experiência elementar com os conceitos de experiências de consumo e consumidor, consideramos que este, (consumidor) mesmo sendo citado nas estratégias mercadológicas como "pessoa" pode ser tomado de forma superficial, sem um aprofundamento filosófico e antropológico.

Assim, na busca por uma fundamentação teórica que colaborasse no estudo do conceito de consumidor no mundo contemporâneo, o conceito de experiência elementar, a partir de Giussani (2009), apresentou-se útil para a Psicologia e outras áreas, como o Marketing, por exemplo, na medida em que abre a discussão para a retomada do eu no contexto das atividades diárias. Essa abordagem tem sido estudada, desde 2005, pelo pesquisador e psicólogo da área social, Miguel Mahfoud (2012). ${ }^{55}$

\footnotetext{
${ }^{55}$ Miguel Mahfoud é professor de Psicologia na Universidade Federal de Minas Gerais (UFMG), atuando na graduação e pós-graduação (mestrado e doutorado). É doutor em Psicologia Social pelo Instituto de Psicologia da Universidade de São Paulo. Realizou estudos de pós-doutorado na Pontifícia Universidade Lateranense de Roma, Itália. Sua linha de pesquisa é principalmente Cultura e Subjetividade, desenvolvendo temas ligados à fenomenologia, cultura popular e experiência religiosa. É editor da revista "Memorandum: memória e história em psicologia"e coordenador do Laboratório de Análise de Processos em Subjetividade (LAPS UFMG). Nos
} 
Antes da apresentação do conceito da experiência elementar relacionado ao marketing, a seguir, vamos apresentar uma breve biografia do autor que formulou o mesmo.

\section{4 - Biografia de Luigi Giovanni Giussani - autor do conceito de Experiência elementar.}

Giussani, teólogo, filósofo e educador privilegiou a formação dos jovens como elemento central de seus estudos. Profundo conhecedor da tradição católica e protestante, estudioso da filosofia antiga e contemporânea, sua obra foi reconhecida em todo o mundo por diferentes grupos sociais e de diferentes credos e etnias por enfatizar um profundo amor pelas pessoas e pela vida.

Nasceu na cidade de Désio, próxima de Milão, na Itália, no dia 15 de outubro de 1922. Em 1937, já adolescente, Giussani transferiu-se para o seminário de Venegono, onde passou oito anos de estudo (o último do ensino fundamental, os três anos do ensino médio e os quatro anos de Teologia).

Durante os anos do curso de teologia, o entusiasmo e as descobertas da adolescência encontraram fundamento e forma adequados num ensino que colocava como centro o acontecimento da experiência humana, e que foi manifesto em diversas obras ao longo de sua trajetória como religioso e educador. Em novembro de 1943 recebeu o bacharelado e especializou-se no estudo da teologia oriental (especialmente sobre os eslavófilos), da teologia protestante norte-americana e no aprofundamento da motivação racional da adesão à fé e à Igreja. Giussani tornou-se um profundo conhecedor das diferentes religiões, sempre na tentativa de resgatar o elemento humano a partir do aprofundamento da fé.

Entre o final dos anos de 1950 e o início dos anos de 1960, publicou os três pequenos volumes que sintetizam o coração da sua proposta: G.S. riflessioni sopra un'esperienza (G.S. Reflexões sobre uma experiência, 1959), Tracce d'esperienza cristiana (Passos de experiência cristã, 1960), Appunti di metodo cristiano (Apontamentos de método cristão, 1964).

últimos anos, vem desenvolvendo o conceito de experiência elementar em suas implicações para a Psicologia. (Mahfoud, 2012) através do Departamento de Psicologia da Faculdade de Filosofia e Ciências Humanas da Universidade Federal de Minas Gerais e ministra as disciplinas com os títulos de: Experiência elementar em Psicologia I e II, Estágio Supervisionado II: Plantão Psicológico e Experiência elementar. Entre 2009 e 2012, o "Grupo Experiência elementar em Psicologia: estudo, pesquisa e intervenção" ministrou diversos cursos de atualização sobre o tema nas cidades de São Paulo, Salvador, Belo Horizonte e Ribeirão Preto. 
De 1964 a 1990, ocupou a cátedra de Introdução à Teologia na Universidade Católica do Sagrado Coração, em Milão. Em algumas ocasiões foi convidado pelos seus superiores para períodos de estudos nos Estados Unidos. No ano de 1966 passou alguns meses em território americano para aprofundar os estudos sobre a teologia protestante americana, publicando, em seguida, em edição acadêmica, uma das raras publicações sobre o argumento, com o título: Grandes linhas da teologia protestante americana. Perfil histórico das origens até os anos 70.

Em 1977, publicou Il rischio educativo (Educar é um risco), no qual reuniu suas reflexões sobre a experiência de vinte anos como educador, primeiro no liceu e depois na universidade, tornando-se um dos livros mais lidos de Dom Giussani, republicado várias vezes.

Em toda a sua trajetória como educador, focou a centralidade da pessoa e o sentido de ser humano de uma forma que ultrapassava os limites étnicos e religiosos. Suas obras foram e continuam a ser estudadas por diferentes gerações de jovens do mundo inteiro. Um fato marcante foi o lançamento de sua obra $O$ senso religioso em inglês ${ }^{56}$, no ano de 1997 , em que representantes de várias origens, entre budistas, judeus e católicos manifestaram o reconhecimento por seu trabalho e sua proposta de análise e conhecimento da trajetória humana.

Dom Giussani morreu em 15 de outubro de 2005, aos 73 anos, em sua casa na cidade de Milão, Itália. Deixou um acervo que compreende mais de 20 obras, traduzidas em várias línguas. (ver relação de obras em anexo)

Especificamente a obra $O$ Senso Religioso ${ }^{57}$, na qual Giussani desenvolveu o tema da experiência elementar, publicada originalmente em 1997, foi o primeiro livro da trilogia $O$ percurso. A obra, considerada pelo próprio autor como um "método" para o conhecimento de si e dos outros, motiva o leitor a redescobrir, a partir de suas exigências elementares, a sua estrutura originária como ser humano, inserida no contexto de sua própria realidade. A

\footnotetext{
${ }^{56}$ A edição em inglês do livro $O$ senso religioso foi apresentada no Palácio da ONU, em Nova York. A convite do Observador Permanente da Santa Sé junto às Nações Unidas, dom Renato Martino, pronunciando-se aí um monge budista (Takagi), um músico judeu (Horowitz) e um teólogo católico (Schindler) (Revista Passos, 2005, p. 33).

${ }^{57}$ Giussani (2009, p.59) discorre sobre o tema da religiosidade e do senso religioso como ponto de partida para a interpretação do tema da Experiência elementar: "Tudo o que dissemos até agora não foi por pura curiosidade de análise, mas sim para chamar a atenção sobre as condições que devem ser respeitadas dentro da atitude com a qual se enfrenta a questão do senso religioso, condições estas que podem ser resumidas em uma disponibilidade às solicitações que a própria questão impõe". [...] "Se a experiência religiosa é uma experiência não podemos senão partir de nós mesmos para olhá-la de frente e colher os seus aspectos constitutivos. Atentemos ao fato de que essas afirmações parecem óbvias, mas espero que depois, discretamente, com a prova dos fatos, aflore que não são nada óbvias $[. .]$.$" ".$
} 
simplicidade e genialidade do autor estão justamente no fato de tratar de temas ligados à antropologia filosófica através de exemplos que refletem a realidade das pessoas. A atualidade do conceito se estende em diferentes perspectivas, conforme Mahfoud (2012, p. 31):

[...] no âmbito da metodologia científica, com o astrofísico M. Bersanelli; no âmbito da Pedagogia, com G. Chiosso; das Ciências Médicas, com G. Cesana; da Jurisprudência com M. Cartabia; da Antropologia Filosófica e Teológica, com S. Grygiel e A. Scola; da Filosofia com C. Esposito, G. Maddalena e P. Ponzio e com C. di Martino. A própria multiplicidade de aplicações atuais daquela Antropologia se tornou objeto de debate no livro organizado por E. Uzzi no Canadá. Um original debate sobre multiculturalismo foi organizado por J. Prades a partir dessa perspectiva. Dois encontros científicos já se dedicaram a debater e identificar a originalidade do conceito de experiência elementar: o Seminário Experiência elementar, revelação e dialogo com as culturas promovido pela Pontifícia Lateranense na Itália em $2004^{58}$ e o Simpósio Internacional e Interdisciplinar sobre Experiência Elementar ${ }^{59}$ realizado no Brasil em 2009, este reunindo pesquisadores de 12 diferentes universidades de Itália, Espanha, Canadá, Japão e Brasil com contribuições das áreas da Psicologia, Psiquiatria, Filosofia, Historia, Sociologia, Educação, Letras, Bioética e Física.

Amatuzzi (2012, p. 12), ao refletir sobre o tema da experiência elementar no prefácio da obra de Mahfoud (2012), classificou esse conceito e a forma como foi apresentado na obra do psicólogo como sendo próximo à fenomenologia, pois "não se trata de um raciocínio formal abstrato, mas de um caminhar pelas sendas de um pensamento existencial que, sem desprezar a lógica, segue os passos da experiência que o leitor é convidado a fazer pela confrontação do que é dito com sua própria vivência pessoal”.

Para a nossa pesquisa, fizemos um recorte e selecionamos os seguintes capítulos do livro Senso Religioso para análise: 1 - Primeira Premissa: Realismo; 2 - Segunda Premissa: Razoabilidade e 3 - Terceira Premissa: Incidência da Moralidade sobre a dinâmica do conhecimento. Esses três capítulos constituem "o fundamento de uma construção fascinante, intensamente humana, que convida, a cada passo, a avaliar criticamente a própria experiência" (Agnelo, 2009. In: Giussani, 2009, p. 12). A escolha desses capítulos evidencia o percurso que queremos seguir nas análises sobre o conceito de consumidor. Vamos partir de casos de campanhas e estratégias de marketing e analisar, segundo essas premissas, de uma forma

\footnotetext{
58 Seminário "Esperienza elementare, rivelazione e dialogo com le culture" promovido pela Pontificia Universidade Lateranense em 21 e 22 de junho de 2004 em Roma, Itália.

${ }^{59}$ Simpósio promovido pelo LAPS - Laboratório de Análise de Processos em Subjetividade do Programa de PósGraduação em Psicologia da Universidade Federal de Minas Gerais e pelo Grupo de Pesquisa e Estudos em Psicologia e Ciências Humanas: história e memória, em 18 e 19 de março de 2009, na Faculdade de Filosofia e Ciências Humanas da Universidade Federal de Minas Gerais em Belo Horizonte - MG.
} 
crítica, como o conceito de consumidor se relaciona aos conceitos de "pessoa" e "experiência".

Após essa apresentação conceitual das premissas e sua relação com a área de Marketing, utilizaremos os pontos do Capítulo 4: Senso religioso: o ponto de partida, que oferece uma espécie de "percurso metodológico" para se enfrentar o tema da experiência elementar. Esses pontos se relacionam a uma análise do próprio "eu" presente em nosso contato com a realidade e com as atividades diárias. Nas palavras de Giussani (2009, p. 60):

Partir de si quer dizer partir da própria pessoa surpreendida na experiência quotidiana. Então, o material de partida não será mais um preconceito sobre si mesmo, uma imagem artificiosa de si; não será mais uma definição de si talvez emprestada das ideias correntes e da ideologia dominante.

Os pontos que o autor apresenta são: $O$ eu-em-ação (como nos observamos em ação), O compromisso com a vida (o compromisso com tudo o que se relaciona com a vida das pessoas entre eles, o amor, o dinheiro, o trabalho, etc.); Aspectos do compromisso (retomar a todo momento a importância da tradição e do presente ); A dupla realidade e a redução materialista ( a realidade mutável e não mutável e o risco da redução materialista frente aos constantes apelos ao consumo).

Esses pontos foram relacionados com algumas campanhas publicitárias do ano de 2013, que serão apresentados no capítulo 4, e parecem se aproximar dos consumidores de uma forma mais humana. Desse modo, tais pontos funcionaram como uma espécie de "crivo crítico" para se realizar a análise das campanhas e da sua abordagem junto ao consumidor.

\section{5 - O conceito de Experiência elementar: reflexões sobre a interface com o conceito de consumidor a partir das premissas (realismo, razoabilidade e moralidade sobre a dinâmica do conhecimento).}

A abordagem da experiência elementar apresentada na obra de Giussani (2009) analisa com profundidade a trajetória da realização humana e procura compreender o ser humano de uma forma mais completa. O contato com a realidade é entendido em termos de: atividades de trabalho diário, relacionamentos, vida em comunidade, estímulos externos, enfim, tudo o que motiva e solicita as pessoas ao convívio com os outros e consigo mesmas. A partir dessas experiências, surgem os relacionamentos, contatos, e questionamentos que as pessoas vivenciam, e que estão presentes na atividade humana. 
O autor define a experiência elementar como "um conjunto de exigências e evidências com as quais o homem é lançado no confronto com tudo o que existe" (Giussani, 2009, p. 24). Todo ser humano carrega em si exigências constitutivas de verdade, de justiça, de beleza, de amor, entre outras. São exigências próprias do homem que, ao longo da vida, são sedimentadas pelo convívio com as tradições familiares, da sociedade, da moda, da história e da memória. Elas se manifestam a partir do contato com a realidade que o cerca e que o estimula e motiva. As evidências se apresentam como o que está "diante dos olhos". O mundo e a realidade a nossa volta existem além da nossa presença física, ou seja, a realidade emerge em nossos contatos diários.

A palavra elementar, nessa proposta, também se relaciona com original, único e primeiro. Assim, todas as experiências verdadeiramente humanas e de personalidade passam "pelo crivo de uma "experiência original" primordial que constitui o ser humano ao se confrontar com a realidade das coisas" (Giussani, 2009, p.16). Nas palavras de seu autor, experiência elementar é definida como:

[...] um conjunto de exigências e evidências com as quais o homem é lançado no confronto com tudo o que existe. [...] A elas podem ser dados muitos nomes, através de diversas expressões, como: exigência de felicidade, exigência de verdade, exigência de justiça, etc. Seja como for, são como uma centelha que põe em ação o motor humano; antes delas não ocorre nenhum movimento, nenhuma dinâmica humana. Qualquer afirmação de uma pessoa, desde a mais banal e quotidiana até a mais ponderada e plena de consequências, só pode ser feita tendo por base esse núcleo de evidências e exigências (Giussani, 2009, p.16).

A experiência a que Giussani se refere, emerge na consciência da pessoa quando esta busca respostas para as suas exigências fundamentais, nos momentos de dor, de alegria, de depressão, de excesso de trabalho e de dificuldades para lidar com as questões práticas do cotidiano, de reflexão, etc.

A experiência elementar representa o "núcleo mais profundo da identidade pessoal e, exatamente por isso, se torna o crivo crítico com o qual cada pessoa se aproxima da realidade para avaliá-la" (Giussani, 2009, p.16). Ela se evidencia através do percurso do conhecimento descrito por Giussani, nos primeiros capítulos de seu livro, como a tríplice premissa: realismo, razoabilidade e incidência da moralidade. Por meio destas três premissas, Giussani sugere um caminho de aberturas para o encontro com o verdadeiro ser humano e de 
como ele, através de suas experiências, reage diante das realidades que lhe são impostas. A seguir, a explicação sobre as três premissas:

1 - Por realismo, Giussani (2009, p. 21) explica que se deve "observar um objeto de modo tal que ele seja conhecido, o método não deve ser imaginado, pensado, organizado ou criado pelo sujeito, mas imposto pelo próprio objeto". Para exemplificar essa premissa, tomamos o exemplo do autor:

Se eu me achasse sentado falando para uma sala lotada, e houvesse um caderno de notas em cima da mesa, o qual eu falasse, entrevisse com o canto do olho, e me perguntasse o que seria aquela brancura que estaria ferindo minha visão, poderia pensar nas coisas mais disparatadas: sorvete derramado, um farrapo de camisa, etc. Mas o método para saber de que verdadeiramente se trata é me imposto pela própria coisa. Isto é, se eu quisesse conhecer de verdade o objeto branquejante, não poderia dizer que preferiria pôr-me a contemplar um outro objeto vermelho, no fundo da sala, ou os olhos de uma pessoa na primeira fila. Deveria, necessariamente, resignar-me a inclinar a cabeça e enquadrá-lo em meu campo de visão, fixando os olhos nele.

Portanto, ao observar, por exemplo, um aparelho celular ou uma boneca, estes possuem características diferentes e se apresentam de forma diversa. É evidente que esses objetos são criados fora das pessoas, e nas experiências humanas diárias, esses objetos já se tornaram conhecidos. Nas palavras do autor: "Aquilo que cria o objeto é o nosso conhecimento, é o espírito e a energia do homem. Tanto é verdade que se o homem não o conhecesse seria como se não existisse" (Giussani, 2009, p. 25).

Após ter contato e conhecer o objeto, o que para Giussani é "apenas o início do conhecimento", parte-se para a formulação de um juízo, uma avaliação desse objeto. A palavra experiência não significa apenas "provar": o homem experiente não é aquele que acumula "experiências - fatos e sensações - a torto e a direito. Semelhante acúmulo indiscriminado gera frequentemente, destruição e esvaziamento da personalidade" (Giussani, 2009, p. 23). Segundo o autor, experiência coincide com o "provar", mas, sobretudo com o "juízo dado a respeito daquilo que se prova". A pessoa é, antes de tudo, consciência. Por isso, o que caracteriza a experiência não é tanto o fazer, o estabelecer relações com a realidade como fato mecânico; [...] "o que caracteriza a experiência é compreender uma coisa, descobrir-lhe o sentido" (Giussani, 2009, p. 23). A experiência, nesse sentido, implica em descobrir o sentido das coisas, ou, usando um termo de Giussani, em dar um "juízo" acerca do fato ou experiência realizada. O crivo para formular este juízo é dado pela experiência elementar. 
O critério para avaliar o objeto, para dar-lhe sentido, pode ser determinado duas formas: "ou o critério com base no qual julgamos o que vemos em nós é tomado fora de nós, ou é encontrado dentro de nós "(Giussani, 2009, p. 23).

Aquilo que "é tomado fora de nós" corresponde às informações que recebemos do nosso contato com a realidade, com o dia a dia, com o que é evidenciado pela moda, pela mídia, etc. Se tivemos uma determinada informação externa, por exemplo, e não conseguimos processar internamente, questionando e analisando se aquele objeto ou acontecimento realmente "me corresponde", então é como se estivéssemos "alienados" diante de tal fato. Por outro lado, se esse juízo é dado por algo interno, imanente, deixa de ser alienante e passa a ser uma experiência original, a partir de algo que nos corresponde.

Como exemplo, vamos analisar como as experiências de consumo são formuladas através das estratégias de marketing ${ }^{60}$. Um dos objetivos dessa atividade é atender as necessidades e desejos dos consumidores através dos processos de troca. Para que esse objetivo seja atingido, os produtos e serviços diversos são apresentados aos consumidores através de técnicas sofisticadas de vendas, promoção, e publicidade e propaganda. Para determinar o que deve ser oferecido para as pessoas de diferentes faixas etárias, classe social, grau de instrução, sexo, entre outros, os profissionais de marketing realizam intensa pesquisa para medir níveis de satisfação e interesse sobre determinado produto ou serviço, e também para criar produtos e serviços novos, estimulando e criando novas necessidades e desejos de consumo a partir desses dados de pesquisa. Tais pesquisas podem ser de natureza quantitativa ou qualitativa, feitas através de métodos experimentais ou não, abordando, principalmente, questões relacionadas aos hábitos, necessidades e desejos de consumo.

A partir da premissa acima, do realismo, conforme Giussani, podemos afirmar que a forma como o consumidor é abordado, emerge das práticas impostas pelo mercado, pela moda e pelas tendências, como parte de algo que é dado externamente e que não parece passar por critérios internos do consumidor. Os consumidores podem pertencer à faixa etária infantil (entende-se aí que é desde o seu nascimento e enquanto bebê), adolescente, jovem, adulto ou da terceira idade. Para cada etapa são desenvolvidos produtos específicos que atendem a uma demanda de consumo que nem sempre foi "dada" pela realidade desses consumidores.

\footnotetext{
${ }^{60}$ Segundo Kotler (2000, pág.30), o conceito de marketing é “o processo social por meio do quais pessoas e grupos de pessoas obtêm aquilo de que necessitam e o que desejam com a criação, oferta e livre negociação de produtos e serviços de valor com outros".
} 
Outro exemplo ocorre quando o consumidor infantil ${ }^{61}$ é abordado por uma estratégia de marketing específica. Em algumas situações, a criança, na estratégia mercadológica, é apresentada como protagonista do processo de decisão de compra. Evidencia-se isso em campanhas de instituições financeiras, compra de imóveis, veículos, entre outros. O seu posicionamento diante da escolha da cor do veículo, da localização da residência, e do banco que oferece "uma poupança para o seu futuro", é fundamental para que se efetive a compra do produto ou serviço pelos pais e responsáveis. A propaganda de produtos direcionados para o público adulto acaba criando estratégias para atingir, em primeiro lugar, a criança que influencia a opinião dos pais na decisão do processo de compra.

Comparando com a premissa do realismo, observamos que a abordagem externa, realizada pela propaganda de produtos infantis, não corresponde à natureza da criança. Não é ela que realiza a compra dos produtos e negocia formas de pagamento e entrega. Ela se torna uma espécie de alvo da propaganda, pois em determinadas situações, não consegue estabelecer um juízo real acerca do produto que está sendo anunciado. Ela é tomada pela abordagem externa e elabora a sua experiência a partir do que é transmitido pelas mensagens e campanhas.

A propaganda infantil não é proibida no Brasil, mas sofre sanções de ONGs que defendem os direitos da criança e do adolescente, além do Conar ${ }^{62}$, que regulamenta os direitos dos consumidores infantis expressos no capítulo II - Princípios Gerais - Seção 11 Crianças e Jovens, além do Código de Defesa do Consumidor, que classifica as propagandas destinadas ao público infantil como "abusivas", se forem comprovados apelos que se aproveitem da "deficiência e inexperiência do julgamento das crianças" 63 . Os pesquisadores do Projeto Criança e Consumo do Instituto Alana ${ }^{64}$, por exemplo, defendem os interesses e as condutas éticas para as práticas mercadológicas direcionadas às crianças. A discussão pautase na afirmação de que um adulto pode avaliar uma informação baseado tanto na sua própria

\footnotetext{
${ }^{61}$ Entende-se como público infantil, para as atividades relacionadas ao marketing, crianças de 3 a 11 anos e 11 meses.

${ }^{62}$ Conselho Nacional de Autorregulamentação Publicitária é uma ONG encarregada de fazer valer o Código Brasileiro de Autorregulamentação Publicitária. O Conar já instaurou mais de 7 mil processos éticos e promoveu um sem-número de conciliações entre associados em conflito. Nunca foi desrespeitado pelos veículos de comunicação e, nas raras vezes em que foi questionado na Justiça, saiu-se vitorioso. 〈http:// www.conar.org.br/> acessado em 18 de fevereiro de 2014.

${ }^{63}$ Seção III - Da Publicidade. http://www.planalto.gov.br/ccivil_03/leis/18078.htm acessado em 18 de fevereiro de 2014.

${ }^{64}$ O Instituto Alana é uma organização sem fins lucrativos criada em 1994, que tem como missão fomentar e promover a assistência social, a educação, a cultura, a proteção e o amparo da população em geral, visando a valorização do homem e a melhoria da sua qualidade de vida, conscientizando-o para que atue em favor de seu desenvolvimento, do desenvolvimento de sua família e da comunidade em geral, sem distinção de raça, cor, posicionamento político-partidário ou credo religioso. Entre outras ações, destacam-se sua atuação na defesa dos direitos e deveres da criança e sua luta pela regulamentação da publicidade infantil.
} 
experiência quanto na habilidade de pesar diferentes fatores ao mesmo tempo, avaliando as possíveis consequências. Alguns autores da psicologia do desenvolvimento afirmam que a criança, em algumas situações, tem condições de se posicionar diante de diferentes situações:

As crianças, desde o nascimento, estão em constante interação com os adultos, que ativamente procuram incorporá-las a suas relações e a sua cultura. No início, as respostas das crianças são dominadas por processos naturais, especialmente aqueles proporcionados pela herança biológica. É através da mediação dos adultos que os processos psicológicos mais complexos tomam forma. [...] A teoria sócio-interacionista de Vigotski apresenta um aspecto construtivista, na medida em que busca explicar o aparecimento de inovações e mudanças no desenvolvimento a partir do mecanismo de internalização [...] (Bock et al., 2002, p.108 e 109).

Retomando Giussani, o método do conhecimento é imposto pelo próprio objeto. Nas experiências diárias o objeto se torna conhecido e se relaciona com cada um a partir do conhecimento, da vivência e do encontro com este objeto. Uma criança de sete anos, por exemplo, que já tem uma vivência em comunidade, na escola e com a família, se relaciona com os objetos e o ambiente em que vive de forma diversa. Ao entrar em contato, por exemplo, com um novo brinquedo, interage com ele a partir do seu conhecimento e de seu repertório de experiências adquiridas durante essa faixa etária. Se ela já teve contato com um brinquedo, ela sabe, por sua experiência, que aquele objeto é para brincar. Se não teve experiência, e se trata de um novo tipo de brinquedo, pode ser estimulada a conhecê-lo e a se relacionar com ele como algo novo. Nesse sentido, retomando o exemplo anterior referente a utilização de crianças em campanhas para adultos, podemos questionar: qual é a experiência que uma criança tem com uma aplicação financeira, ou com a compra de um imóvel para a família?

O marketing infantil se interessa pela fase das descobertas infantis, pois pode gerar bons negócios. A criança como consumidora é apresentada às propagandas de diferentes produtos [que podem ser um brinquedo, um alimento infantil, ou até mesmo um carro novo para o papai] de forma passiva. Os argumentos visuais e de texto utilizados nessa apresentação podem ser realizados através de um filme na TV ou na internet, ou ainda, numa propaganda de revista, e até mesmo num outdoor que se apresenta em seu caminho para a escola. Nesses filmes e propagandas aparecem elementos do seu dia a dia, tais como: imagens que remetem à ideia do papai e da mamãe, do coleguinha da escola, da sua professora, e que 
testemunha uma mensagem em que "lhe dizem" como comprar e por quê é importante ter aquele determinado brinquedo ou alimento. ${ }^{65}$

Quanto maior for a persuasão e a repetição da mensagem, maior será a percepção positiva ou negativa da criança diante do produto que está sendo proposto pela propaganda. Nesse contexto, podem surgir situações extremas de tensão familiar, por exemplo, para a compra de produtos e serviços que foram divulgados através de propagandas para as crianças. Algumas ações de marketing estimulam positivamente o consumo de produtos adequados para as diferentes faixas etárias, porém, podem também motivar o amadurecimento precoce, a violência infantil, a obesidade, o stress familiar etc., devido à insistência e ao caráter persuasivo das mensagens. ${ }^{66}$

A questão do caráter persuasivo das mensagens publicitárias nas crianças é tão relevante que, de acordo com Linn (2006, p. 162), se cada adulto pudesse analisar como o conteúdo midiático das revistas, programas de TV e música tiveram algum "impacto nos seus ideais de beleza, virilidade, sexo ou romance", se surpreenderia com os resultados.

O marketing infantil, nesse contexto, pode desconhecer ou negligenciar o consumidor infantil enquanto pessoa, durante essa fase em que as necessidades e desejos estão sendo ensinadas para esse público. A publicidade que trata as crianças apenas como consumidores infantis, menosprezando características que lhe são inerentes nessa faixa etária, como ser humano, parece desrespeitar essa etapa do crescimento ao divulgar produtos e serviços que geram, por exemplo, submissão - como as campanhas que são criadas para gerar certo "grau de dependência" por determinados personagens infantis para diferentes categorias de produtos. Por exemplo, uma criança que simpatiza com determinado personagem, passa a desejar o consumo de produtos de higiene pessoal, roupas, brinquedos e alimentos que tenham na sua embalagem ou na sua propaganda argumentos de venda sempre relacionados ao mesmo personagem. Isso cria um círculo vicioso e toda a família pode se ver refém dessa situação.

Linn (2006, p. 94) esclarece essa questão ao afirmar que "submissão, compra por impulso, autodefinição pelo que se possui e busca da felicidade pela aquisição de bens

\footnotetext{
${ }^{65}$ Na pesquisa "Consumismo na Infância", realizado no mês de fevereiro /2010, pelo Instituto Alana, os pais de filhos na faixa etária entre 3 e 11 anos de idade, apontaram, espontaneamente, o que alguns filhos costumam pedir após serem expostos às ações do marketing infantil em programas de TV para criança. Os pequenos - na faixa etária dos 3 aos 7 anos, são mais suscetíveis a propagandas de doces, bolachas e guloseimas , enquanto os maiores, de 7 a 11 anos, são mais suscetíveis a ações que divulgam roupas e videogames.

${ }^{66} \mathrm{Na}$ pesquisa "Consumismo na infância", p. 30, sete entre 10 pais entrevistados, prioritariamente do sexo masculino, com idade entre 36 e 40 anos, da classe social D/E, são influenciados pelos pedidos dos filhos na hora da compra. Também, na opinião dos pais, os maiores influenciadores dos pedidos dos filhos são as propagandas, seguidos da influência dos personagens de programas infantis.
} 
materiais são traços que o marketing impõe aos consumidores infantis." E completa: "todos eles vão contra a criatividade, que se alimenta de recursos internos e não preceitos, modas, ilusões, prêmios". Parece que essas formas de marketing infantil são prejudiciais ao desenvolvimento sociocultural, cognitivo e psicológico do público infantil.

Para Giussani, a realidade provoca a abertura para algo que impressiona e move a buscar algo além daquilo que se apresenta. No marketing infantil essa "abertura" é gerada a partir de algo artificial, que aparentemente atende as necessidades e desejos das crianças, mas em algumas situações, pode não corresponder às exigências reais (físicas, emocionais e psicológicas) do consumidor infantil como ser humano. E as crianças, em algumas situações, não tem como fazer tais avaliações sozinhas.

Se, ao contrário, ao divulgar mensagens sobre produtos e serviços, os publicitários se colocassem no lugar do próprio consumidor, se tratassem as crianças como seres humanos, talvez o trabalho fosse diferente. A abordagem da experiência elementar, segundo essa primeira premissa, o realismo, poderia ser utilizada como proposta para se trabalhar mensagens adequadas e formadoras de consumidores mais críticos e não submissos. Repensar o marketing infantil segundo essa ótica significa focar o uso de técnicas de persuasão e marketing partindo-se da realidade que emerge do consumidor - a criança, e sistematizar práticas mais adequadas de abordagem para esse público específico. Isso implica em, talvez, questionar toda a teoria e prática das atividades de marketing infantil, de modo que a sua própria definição, "atender as necessidades e desejos" seja realmente utilizada em benefício do consumidor infantil como ser humano.

Retomando a premissa do realismo de Giussani, o autor nos ajuda a esclarecer um ponto importante: adotar sempre uma posição razoável diante de um fato ou de um objeto desconhecido por nós. Um objeto que é desconhecido passa pelo nosso crivo crítico ${ }^{67}$ para que possa corresponder a nós como seres humanos. Assim, retomamos o exemplo de Giussani (2009, p. 27):

Uma mãe esquimó, uma mãe Terra do Fogo e uma mãe japonesa dão à luz seres humanos que são todos reconhecíveis como tais, seja pelos caracteres exteriores seja pela marca interior. Assim, quando eles disserem "eu", utilizarão essa palavra para indicar uma multiplicidade de elementos derivados de diversas histórias, tradições e circunstâncias. Mas, indubitavelmente, quando disserem "eu" usarão tal expressão também para indicar uma face interior, um "coração", como diria a Bíblia, que é igual para cada um deles, embora traduzido das mais diversas maneiras".

\footnotetext{
${ }^{67}$ Para Giussani, crivo crítico é o mesmo que "experiência original”, algo que está intimamente ligado a nossa natureza humana.
} 
O método do conhecimento da experiência elementar dada por um objeto exige realismo e crivo crítico [experiência original] para que possa estabelecer correspondência com as exigências que cada ser humano carrega em si.

2 - A segunda premissa de Giussani é sobre a razoabilidade. Nela, o sujeito aparece em primeiro plano, pois é ele que age a partir do real que se apresenta. Comparada com a primeira premissa, Giussani $(2009$, p. 31) afirma:

Pela primeira premissa - necessidade de realismo - viu-se prevalecer o objeto; com efeito, o método com o qual se enfrenta qualquer coisa é determinado pelo objeto, e não imaginado caprichosamente pelo sujeito. A segunda premissa, por sua vez, coloca em primeiro plano o sujeito que age: o homem.

A razoabilidade é um "modo de agir que exprime e realiza a razão". A razão, para Giussani (2009, p. 31) "é a capacidade de dar-se conta do real segundo a totalidade dos fatores". Ao tomar contato com o real, o uso da razão provoca "aberturas" para se relacionar com o objeto. Nas palavras de Giussani:

O objeto de um estudo exige realismo, o método é imposto pelo objeto; mas, concomitantemente e complementar a isso é preciso que o trabalho sobre o objeto respeite a exigência da natureza do homem que é a razoabilidade: possuir motivos adequados ao dar passos na direção do objeto do conhecimento [...]. (Giussani, 2009, p.43).

O autor enfatiza que se deve partir da distinção: "como percebemos que uma atitude é ou não razoável?” (Giussani, 2009, p.43). A partir da nossa relação cognitiva com o real desenvolve-se um método de observação crítica dos fatores que nos correspondem enquanto pessoas. Tomamos um exemplo de Giussani (2009, p. 32):

Por exemplo, se um amigo nosso aparecesse vestido como um cavaleiro
medieval, com elmo e armadura, numa época do ano bem longe do Carnaval,
e, às nossas espantadas perguntas, respondesse seriamente não ter a certeza
de que alguém entre os presentes não nutrisse intenções agressivas contra ele
e que, consequentemente, achara oportuno precaver-se dessa eventualidade,
sentir-nos-íamos diante de uma anormalidade: a atitude do nosso amigo
certamente não seria considerada razoável.

No exemplo acima, a atitude da pessoa que aparece vestida de cavaleiro parece ser não razoável diante da "totalidade dos fatores". Parece ser uma atitude inadequada. Só será 
adequada se a pessoa estiver se preparando, por exemplo, para participar de uma cena numa peça de teatro.

Giussani também nos alerta para o uso reduzido da razão, isto é, "não limitar o âmbito da razoabilidade”. Nesse ponto, o autor indica dois argumentos (Giussani, 2009, p. 33):

a) Muitas vezes o racional não é identificado como o "demonstrável", no sentido estrito do termo; b) O razoável tampouco se identifica com o "lógico". A lógica é um ideal de coerência: estabeleçamos certas premissas (como hipóteses), desenvolvamo-las coerentemente e teremos uma "lógica". Se as premissas forem erradas, a lógica perfeita dará um resultado errado.

Para o primeiro argumento podemos destacar, por exemplo, o amor de um pai com relação a um filho. Às vezes não é “demonstrável” e nem por isso deixa de ser razoável. Sobre o segundo argumento - o que "é razoável tampouco se identifica como lógico", podemos observar, por exemplo, quando um jovem, apesar das adversidades do contexto em que está inserido, se destaca dos demais. A lógica seria que o ambiente no qual esse jovem estivesse inserido, deveria ser determinante para seu futuro. Porém essa "lógica" nem sempre se cumpre. O desenvolvimento de um jovem é possível, mesmo em condições precárias, desde que suas atitudes sejam razoáveis, adequadas ao que ele espera e almeja.

Um exemplo para se discutir a premissa da razoabilidade e o marketing infantil, relaciona-se com a capacidade das crianças brincarem e interagirem com os brinquedos. Como afirma Susan Linn (2006, p. 89):

[...] brincar é um componente fundamental de uma infância sadia e está inextricavelmente ligado à criatividade. A habilidade de brincar está no centro de sua capacidade de arriscar, de experimentar, de pensar criticamente, de agir em vez de reagir e de tornar a vida significativa.

Devido ao fato das crianças brincarem e se relacionarem com o mundo em que vivem, torna-se importante refletir sobre o impacto do marketing infantil, por exemplo, ao criar e divulgar determinados brinquedos que incitam a violência, a sexualidade e o desenvolvimento precoce. Assim, deve-se observar atentamente, como exemplo de atitudes não razoáveis, o caso dos apelos à sexualidade das campanhas publicitárias de produtos infantis, que enfatizam esse distanciamento do "mundo das crianças" e valorizam o "mundo dos adultos" com objetivo mercadológico. Exemplos de brinquedos dessa natureza são as bonecas com corpos de moças, que podem despertar a vontade de usar roupas adultas e maquiagem. 
Recentemente, a ANVISA - Agência Nacional de Vigilância Sanitária (2012, citado em Cavalcanti), abriu uma consulta pública para definir novas regras para a comercialização de maquiagem, perfumes e desodorantes infantis. A questão do debate proposto por esse órgão do governo estava diretamente ligada à proteção quanto à saúde e segurança das crianças no que se refere ao uso desses produtos para regulamentar as práticas comerciais do produto. A questão tinha um propósito mais mercantilista, de atender às práticas vigentes de consumo, do que de cuidado com as crianças que poderiam ser expostas a esses produtos. $\mathrm{O}$ tema debatido entre psicólogos e pedagogos foi de que, na verdade, esse tipo de produto não deveria ser produzido e vendido para crianças, pois se trata de um produto para adultos, com versões, cores e sabores para "encantar" e atrair o público infantil. No mesmo artigo, a psicóloga Mariana Schwartzmann, especialista em adolescência pela UNICAMP Universidade de Campinas argumentou: "uma criança deve ser criança, e crianças não usam maquiagem. É mais uma atitude que acaba abreviando a infância” (2012, citado em Cavalcanti).

O contato das crianças com esses tipos de brinquedo prejudica de certa forma, o seu desenvolvimento social e cognitivo. Por ser uma atitude não razoável, ele contradiz a lógica e a razão.

Ao tomar contato com a realidade que a cerca, a criança encontra e é provocada por várias experiências externas que a comovem e a levam a vivenciar novas aberturas. Como esclarece Giussani (2009, p.169):

[...] diante do mar, da terra, do céu e de todas as coisas que neles se movem, eu não fico impassível; sou animado, movido, comovido pelo que vejo, e esse pôr-se em movimento é por uma busca de alguma outra coisa.

E é dessa forma que a realidade toma e envolve uma criança em desenvolvimento. Tudo é captado como um estímulo e a leva a experimentar e vivenciar aquela experiência. E nesse ponto o Marketing infantil ajuda a provocar algumas dessas aberturas através de ações que levam as crianças a manifestarem um sentimento de desejo por determinado brinquedo ou produto alimentício, e a terem atitudes semelhantes às de seus personagens favoritos, que podem não ser adequados para aquele período de suas vidas.

A presença de pais e responsáveis para esclarecer atitudes e pedidos de consumo infantis por determinado produto ou serviço é primordial nessa fase. Não é uma atitude razoável pais e educadores se absterem de sua responsabilidade por orientarem a escolha dos filhos por produtos e serviços que são divulgados na mídia. Tfouni, Aoki e Souza (2010, p. 
140), propõem, ao analisarem o discurso da propaganda junto a crianças em idade escolar que:

[...] seja atribuição da escola mostrar aos alunos o funcionamento perverso da mídia, que os impulsiona a consumir artigos supérfluos que em nada contribuem para o sucesso escolar: o novo modelo de tênis, o pendrive mais moderno, o ipad, mochilas da moda, etc. Esse objetivo pode ser atingido se peças publicitárias forem analisadas como parte do conteúdo escolar, visando construir uma cadeia nova de associações entre produto oferecido e sujeito, possibilitando a este um posicionamento crítico.

Esta seria uma atitude razoável dos educadores, de acordo com a segunda premissa de Giussani, para interpretar as diferentes linguagens que interpelam a construção de significados na infância.

Também não é uma atitude razoável da parte de profissionais de marketing atuarem no sentido de estimular o consumo de produtos não adequados para crianças em diferentes faixas etárias. A legislação em vigor no CONAR - Conselho Nacional de Auto Regulamentação Publicitária declara na seção 11 - “Crianças e Jovens”, Art. 37- No anúncio dirigido à criança e ao jovem: a) dar-se-á sempre atenção especial às características psicológicas da audiência-alvo; b) respeitar-se-á especialmente a ingenuidade e a credulidade, a inexperiência e o sentimento de lealdade dos menores. ${ }^{68}$

Um estudo recente de uma pesquisada da UNICAMP - Universidade Estadual de Campinas, SP, Maria Aparecida Belintane Fermiano, autora da tese de doutorado "Préadolescentes (tweens) - desde a perspectiva da teoria piagetiana à da psicologia econômica, sobre a trajetória e o risco do consumismo entre os pré-adolescentes entre 8 e 14 anos - que estão no meio do caminho entre a infância e adolescência, afirma que "crianças muito ativas, que gostam de novidades, de comprar, apreciam estar com os amigos e ficam pouco tempo com a família. Eles são os alvos preferenciais do marketing e da mídia, por gastarem dinheiro principalmente com coisas desnecessárias, e passarem tempo exagerado diante da televisão" (2010, citado em Gardenal). O tween passa muito tempo em casa sem a companhia dos pais, que, em sua maioria, trabalham em tempo integral. Já possuem o próprio dinheiro, fruto da mesada, e sabem se relacionar com diferentes situações de consumo. Também utilizam a internet e a TV e são alvos de ações publicitárias durante toda a programação a que estão expostos.

\footnotetext{
${ }^{68}$ Retirado do World Wide Web <http://www.conar.org.br> em 11 de outubro de 2010. A última revisão do presente código data de maio de 1980.
} 
A pesquisadora, em seu estudo, dedicou especial atenção ao processo de erotização precoce de meninos e meninas, principalmente das meninas, "resultante da tentativa de imitar os mais velhos para pertencer ao grupo, aliada ao forte consumismo." Para a pedagoga, existe uma diferença entre o faz de conta e o comportamento cotidiano. "Uma coisa é brincar de ser mocinha, o que é saudável e faz parte do desenvolvimento normal. Mas a criança está vivenciando isso diariamente, não pode sair sem passar gloss, ir à escola sem maquiagem e salto alto. (2010, citado em Gardenal).

O risco para as crianças que são expostas a ações de marketing infantil é que elas recebem informações não razoáveis (não adequadas). Os brinquedos que lhes são dados, as roupas, os alimentos, as propagandas a que assistem em seus canais preferidos, não correspondem à sua realidade enquanto crianças.

3 - A terceira premissa é definida como a incidência da moralidade sobre a dinâmica do conhecimento. Nesse sentido, a palavra moralidade, que vem de moral e se apresenta como um "conjunto de regras de conduta consideradas como válidas" ${ }^{69}$ pode variar de acordo com a dinâmica da pessoa durante uma determinada experiência. Para essa conclusão, observa-se que o homem não é só o uso da razão inseparável da unidade da pessoa. Assim, Giussani (2009, p. 46) estabelece que “a razão é imanente a toda unidade do nosso eu, está organicamente relacionada; por isso, diante de uma dor física, de uma raiva, de uma decepção pela incompreensão dos outros, não se usa bem a razão". O uso da razão diante de um acontecimento parte de uma experiência pessoal a partir de algo que a comove. Essa comoção não está dissociada de uma unidade profunda que o ser humano possui entre corpo, mente e espírito.

Desde que nascem, as crianças começam a se relacionar com o mundo externo através de uma infinidade de símbolos e objetos, que são apresentados, na maioria das vezes, pelos próprios pais em seu dia a dia.

Os diferentes meios de comunicação fazem parte do entretenimento e das atividades diárias de toda a família, e acabam, de uma forma ou de outra, interferindo até mesmo nas relações entre pais, filhos, amigos e professores. Mas isso nem sempre é percebido.

Basta acessar o You Tube 70 e fazer a busca por um filme sobre "criança e computador" ou, "criança e seu tablet ${ }^{71}$ ", que logo podemos ver uma infinidade de pequenos vídeos domésticos, filmados muitas vezes a partir da câmera de um celular, mostrando crianças e

\footnotetext{
${ }^{69}$ Ferreira, Aurélio Buarque de Holanda. (1999). Novo Aurélio Século XXI: o dicionário da língua portuguesa $3^{\text {a }}$. Ed.- Rio de Janeiro: Nova Fronteira.

${ }^{70}$ Rede social de compartilhamento de vídeos.

${ }^{71}$ Equipamento eletrônico que tem como função dar suporte de mobile aos usuários.
} 
bebês interagindo com modernos equipamentos digitais através de um touch ${ }^{72}$ na tela. Esses filmes são feitos pelos pais que, maravilhados com a tecnologia e com o momento de descoberta dos filhos pelas novidades, acabam compartilhando com amigos nas redes sociais, fotos, vídeos e imagens dos filhos nos momentos de brincadeiras.

As crianças são apresentadas à tecnologia, cada vez mais cedo e passam a brincar com equipamentos, antes destinados apenas ao mundo dos adultos. E esse "encontro" precoce com esses equipamentos e outros estímulos, muitas vezes, acaba de certa forma atropelando um pouco o desenvolvimento infantil, aproximando os pequenos de uma realidade que ainda não é apropriada à sua idade.

A dinâmica dos encontros que acontecem de forma precoce para as crianças incide sobre a "moralidade do conhecimento", ou seja, impacta sobre o que elas trazem como exigências próprias, características de todo ser humano, e que nessa fase ainda estão sendo despertadas.

Para refletir sobre essa premissa, é útil o conceito de encontro a partir dos estudos de Guardini (2002). A possibilidade do encontro com o outro é reveladora e faz parte da dinâmica humana. As pessoas se encontram em diferentes locais, em situações previstas e inusitadas, em casa, junto à família, ou no local de trabalho, na escola e na rua. Encontrar é estar diante do outro, que pode ser uma pessoa, um local, uma pintura, uma música, etc. É deparar-se com uma realidade que circunda o dia a dia. Um encontro não é qualquer encontro!

Romano Guardini $(2002$, p.) afirma que "um encontro, propriamente dito só se realiza quando é o homem que se choca com a realidade". Então, um encontro não é mera obra do acaso, mas guarda em si a possibilidade de uma interação e de uma reciprocidade. Guardini também afirma “[...] antes de tudo, é um choque entre mim e algo real”.

Refletir sobre o encontro pode ser uma experiência de abertura à totalidade do que é mais essencial e constitutivo da pessoa - encontrar é interagir com a realidade, colocar-se diante dela e tomar para si algo que se apresenta naquele exato momento.

Exige atitude, movimento e maravilhamento pela presença do outro! Os verdadeiros encontros são espontâneos, sinceros e sem questionamentos. Eles não são planejados como as atividades de trabalho, mas podem acontecer, até mesmo, no momento de uma atividade planejada, e a pessoa não se dar conta disso. Análogo ao conceito de encontro, acha-se em Giussani que:

\footnotetext{
${ }^{72}$ Termo que se relaciona a "toque". Tradução nossa.
} 
Não é um verdadeiro encontro se não exerce sobre nós de algum modo um chamado. E cada chamado é sempre objetivamente uma proposta [...]. No imenso coro de propostas que constitui a trama da sua existência, o homem, por natureza é impelido a comparar, e imediatamente a comparar cada proposta única com aquela complexa estrutura original - princípio evidência, exigência - que constitui seu ser. Se a proposta feita parece, nesta comparação, solicitar sua autêntica exigência, valorizar as suas possibilidades, então automaticamente o homem sente simpatia por ela e a aprova (Giussani, 2007, p. 168 citado por Mahfoud, 2012, Curso Experiência elementar em psicologia).

Giussani, a partir da primeira premissa, o realismo, apontou um caminho para que os encontros se tornem uma realidade e uma experiência reveladora. Faz parte da vida dos adultos se relacionarem, em comunidade, na família e com seus amigos, e participarem de encontros. Muitos se revelam dessa forma, descrita pelo filósofo. Alguns nem sempre são vividos com essa intensidade, pois falta na pessoa uma tomada de posição diante do que realmente acontece em sua vida.

Cada coisa que vivemos, cada proposta é um chamado para a realidade. A realidade se apresenta como uma espécie de "promessa". Para que essa promessa, esse impacto realmente exerça em nós uma experiência positiva, ela deve ser aprimorada, vivenciada e até mesmo "saboreada".

Quando duas pessoas se conhecem, e do primeiro olhar acontece um "encontro" amoroso, por exemplo, isso é algo verdadeiro. O real se apresenta na forma de um momento que, algumas vezes, pode impactar o resto da vida daquelas pessoas.

Um exemplo descrito no texto de Guardini (2000) mostra a situação de dois jovens na universidade para descrever a experiência do encontro com os estudos na vida adulta. Um deles está inserido na universidade com o objetivo único de conseguir um bom emprego, de se tornar referência em sua área e ter reconhecimento profissional. Isso é o que se espera da maioria dos jovens acadêmicos para que, ao se formarem, estejam aptos a enfrentar o dia a dia do trabalho como se fossem veteranos e prontos a resolver todo o tipo de problema a ser enfrentado em sua área de atuação profissional. $O$ mercado exige essa tomada de posição dos jovens, e as universidades ainda não estão preparadas para enfrentar esse desafio com os jovens formandos.

O outro jovem desse exemplo, ao contrário, procura descobrir através dos estudos um significado para sua formação. Dedica-se às pesquisas e enfrenta com maturidade as infinitas possibilidades que o conhecimento pode lhe trazer. Para qual dos dois alunos os estudos se apresentam como um verdadeiro "encontro"? Para aquele que só busca nos estudos um meio 
de atingir as metas profissionais, ou para aquele que não se restringe aos fatos e se aprofunda nas leituras e nos estudos como forma de adquirir um novo olhar para o pensamento imediato?

Guardini (2000,p.23), ao refletir sobre esse exemplo, lançou o seguinte questionamento: "Por fim, qual dos dois é mais profundo e autêntico, mais plenamente ele mesmo? No sentido das energias vitais imediatas, com certeza, o primeiro; mas no sentido da autêntica realização de si mesmo, o segundo." Essa tomada de posição diante da realidade exige maturidade! Isso não é por acaso! As pessoas passam pelo processo de amadurecimento para a vida adulta através dos exemplos e de como foram educadas na infância, como se desenvolveram e como adquiriram essa capacidade de enfrentar a realidade que se apresenta em seu dia a dia.

Outro ponto abordado pelo autor diz respeito ao exercício da liberdade, que ajuda na tomada de posição diante dos fatos reais que se apresentam em nossa vida, e dos encontros que envolvem duas ou mais pessoas. Aquelas que agem com liberdade, enfrentam as questões que se colocam em seu dia a dia e a realidade com uma tomada de posição consciente que faz com que possam aderir ou recusar determinada situação que se apresenta. No encontro existe a relação com o outro e, quando se trata da relação entre as pessoas existe o respeito à alteridade.

O exercício da liberdade ante a alteridade se dá, conforme Giussani, (2003, p. 17), quando efetivamente fazemos escolhas de aderir ou não à proposta do outro sem manipular a situação. Ele diz "Ser livre é condição para ser capaz de acolher - abraçar o diferente - do contrário uso o outro, o manipulo." Relacionar-se com o outro com esse respeito à alteridade exige também uma tomada de posição diante da realidade.

Enquanto a vida passa com as suas contradições, as pessoas tem a chance de mudar e viver intensamente o que é a realidade da vida.

Outra reflexão diz respeito ao distanciamento que devemos guardar na relação com o outro. Num momento de dor, de perda vivenciada por uma pessoa, podemos estar juntos em relação com o outro, e num verdadeiro encontro apenas pela nossa presença sem interferência. “[...] a comoção une, deixando separado", afirmou Giussani (2003). A consciência de si pode se dar a partir desse encontro, que guarda um distanciamento, mas, ao mesmo tempo, uma presença significativa de um diante do outro numa situação de fragilidade da vida humana. 
Nesse sentido podemos refletir como, em nossa vida profissional, podemos identificar a possibilidade de sermos nós mesmos, ao nos distanciarmos daqueles momentos de extremo conflito para aderir ao conhecimento do outro (aqui podemos considerar o outro como uma pessoa ou atividade profissional).

Retomando a terceira premissa de Giussani - "incidência da moralidade na dinâmica do conhecimento" reconhecemos na aproximação com o tema "encontro", proposto por Guardini, que ambos os autores estabelecem como proposta que os verdadeiros encontros acontecem na dinâmica da própria atividade humana, quando algo "move e comove" as pessoas a tomarem certos caminhos e a vivenciarem determinadas experiências. No caso específico das crianças que se encontram com diferentes situações em sua vida são movidas a experimentar diferentes sensações que podem ser determinantes para seu desenvolvimento pessoal e social. Entretanto, essas crianças ainda não tem uma liberdade de escolha por que nem sempre estão preparadas para essa atitude. Para os adultos, o pleno exercício do encontro que comove, emociona e move a tomada de atitudes, acontece quando conseguem exercer com liberdade a sua individualidade em relação ao outro, respeitando as características físicas, emocionais e individuais. Num sentido mais amplo, o "encontro com o outro se torna constitutivo da pessoa" (Mahfoud, 2012).

As três premissas: realismo, razoabilidade e incidência da moralidade sobre a dinâmica do conhecimento definem o método de conhecimento para se entender o conceito de experiência elementar. Ao relacionarmos essas premissas com exemplos de atividades de marketing infantil, podemos observar que a atividade de marketing, numa tentativa de se aproximar cada vez mais do consumidor infantil, distancia-se de uma abordagem mais humana em relação a esse público específico. O conceito de consumidor, segundo essa análise, está condicionado a acontecimentos externos, alheios à sua vontade, determinados por estratégias mercadológicas.

No próximo capítulo, vamos apresentar uma discussão sobre a Experiência elementar, a Psicologia e o Marketing e os modos como esses temas se relacionam, a partir da análise de alguns exemplos de abordagens mercadológicas, conforme as novas tendências do marketing contemporâneo. Os exemplos são campanhas reais de empresas conceituadas, que estão disponíveis em sites na internet. 



\section{5 - EXPERIÊNCIA ELEMENTAR, PSICOLOGIA E MARKETING: COMO ESSES TEMAS SE RELACIONAM COM O CONCEITO DE CONSUMIDOR NO MUNDO CONTEMPORÂNEO.}

Através do percurso que realizamos nessa pesquisa, constatamos que a aproximação entre as áreas de Marketing e Psicologia contribuiu, de forma concreta, para as decisões estratégicas sobre o conceito de consumidor em diferentes contextos históricos, sociais e econômicos. No final da década de 1980, as novas tendências da área de Marketing começaram a evidenciar novas possibilidades de se conceituar o consumidor, a partir de uma necessidade de se reconhecer a pessoa presente nas atividades de consumo. Essa necessidade emerge frente às exigências impostas pelo mercado e pelo próprio consumidor, que se tornou mais crítico e participativo diante das problemáticas que envolvem o consumo consciente, a preservação do planeta e as desigualdades sociais.

Ao conhecer a abordagem da experiência elementar e a ideia do humano que emerge nas relações de consumo, pudemos observar uma possibilidade de ampliação da discussão do conceito de consumidor, que poderia ir além das estratégias mercadológicas já utilizadas, além da aproximação com a área da psicologia.

O conceito de consumidor na literatura acadêmica e tradicional de marketing, como já foi apresentado, faz parte da estratégia mercadológica e está associado à disciplina de Comportamento do Consumidor. Para Rodrigues (2013, p.1451) em geral, "a literatura sobre comportamento do consumidor assume a linha de estudos das pessoas com especial atenção às suas ações e reações no consumo de produtos e serviços".

Nos últimos anos, o conceito de consumidor tem assumido um papel diferenciado no contexto da área. A definição da área de Marketing, proposta pela AMA $^{73}$ (American Marketing Association) em 2004, enfatiza a posição do consumidor de forma mais específica

\footnotetext{
Marketing é a função organizacional e um conjunto de processos para criação, comunicação e entrega de valores aos consumidores e ao gerenciamento do relacionamento com o consumidor, de tal forma que beneficie a organização e os stakeholders (AMA, 2004, in Keefe, 2004 citado por Ajzental, 2010, p. 243).
}

\footnotetext{
${ }^{73}$ A American Marketing Association é uma organização respeitada, composta por 38.000 membros, que existe há mais de sessenta anos. Muitos profissionais a veem como o órgão que estabelece as práticas e a educação relacionadas ao marketing. Disponível em:<http://www.administradores.com.br/noticias/administracao-enegocios/ama-redefine-o-marketing-o-que-importa-e-o-cliente/2181/> acessado em 25 de fevereiro de 2014.
} 
Diferente da definição anterior, de 1985, a AMA usava o termo "indivíduos" para se referir às pessoas e, a partir de 2004, passou a utilizar o termo "consumidores" como parte do processo do desenvolvimento da atividade em si.

A utilização do termo "pessoa" para se referir aos consumidores só foi observado mais recentemente na literatura acadêmica do marketing. Isso pode ser reflexo das tendências de se identificar cada vez mais a presença de um “eu” consumidor na definição das estratégias.

As novas tecnologias, as redes sociais e o engajamento dos consumidores em causas sociais impulsionam a necessidade de uma mudança efetiva nas estratégias mercadológicas que abordam o consumidor em seus diferentes papéis ${ }^{74}$ :

Os consumidores acreditam mais uns nos outros do que nas empresas. A ascensão das mídias sociais é apenas reflexo da migração da confiança dos consumidores das empresas para outros consumidores [...]. Os consumidores voltam-se para o boca a boca como uma maneira nova e confiável de propaganda. [...] Todos esses achados das pesquisas servem como advertência inicial para as empresas, no sentido de que os consumidores, em geral, perderam a fé nas práticas de negócios, algo que está muito além do alcance dos profissionais de marketing. Infelizmente, o marketing é parcialmente responsável por isso. Marketing é considerado sinônimo de vender, usar a arte da persuasão e até mesmo de manipulação (Kotler, 2010, p.35).

A resposta da área de Marketing frente às novas tendências tem gerado práticas de mercado mais focadas na perspectiva da pessoa presente no consumidor.

Alguns exemplos vem de empresas que organizam campanhas educativas para redução do consumo de álcool, de drogas, de combate à fome, de erradicação da pobreza, e de apoio a causas ambientais, enfatizando a importância da relação "eu" consumidor com os desafios da humanidade. Porém, em muitos casos, ainda existe uma forte tendência de se criar campanhas com essas temáticas apenas pensando em resultados de imagem da empresa, sem preocupação com o impacto que a geração desse tipo de conteúdo pode oferecer ao consumidor. Uma pesquisa realizada no ano de 2012, pelo Instituto $\mathrm{AKATU}^{75}$, relatou a mudança na percepção

\footnotetext{
${ }^{74} \mathrm{Na}$ literatura da área de Marketing o termo consumidor pode representar papéis diferentes no processo de compra e para cada um dos papéis existe uma estratégia diferenciada de abordagem: o consumidor usuário, o consumidor influenciador e o consumidor comprador.

${ }^{75}$ Criado em março de 2001, o Instituto Akatu pelo Consumo Consciente é uma organização governamental, sem fins lucrativos, que busca conscientizar o consumidor para o seu papel transformador por meio da utilização de seu consumo como instrumento de construção da sustentabilidade.

A palavra Akatu vem do tupi e significa, ao mesmo tempo, "semente boa" e "mundo melhor". É o que o Akatu propõe: que os consumidores se tornem sementes boas para a construção de um mundo mais sustentável. Representa a convicção de que um mundo melhor está contido nos gestos cotidianos de cada pessoa. Disponível no site < http://www.akatu.org.br/Content/Akatu/Arquivos/file/Relatorio_akatu2013.pdf. Acessado em 12 de abril de 2014.
} 
dos consumidores sobre as mensagens que enfatizam o posicionamento de empresas e produtos sobre os problemas relacionados à preservação ambiental, responsabilidade social e sustentabilidade. Entre os objetivos dessa pesquisa estavam: "compreender e monitorar a percepção do consumidor sobre seu próprio poder de consumo e suas responsabilidades [...]" e "compreender e monitorar a percepção do consumidor brasileiro sobre a responsabilidade social das empresas, de modo a tornar mais efetivas as estratégias para sua sensibilização." (AKATU, 2013, p. 7). Entre os resultados desse trabalho apresenta-se uma mudança significativa na forma como o consumidor entende a relação entre consumo consciente e sustentabilidade:

\begin{abstract}
A preferência pelo "caminho da sustentabilidade" prevalece em todas as categorias de assimilação do consumo consciente. Há, também, forte correlação entre uma maior consciência no consumo e uma maior preferência pelo "caminho da sustentabilidade [...] (AKATU, 2013, p. 11).
\end{abstract}

Outro estudo realizado pela MSC 2012 - Monitor de Sustentabilidade Corporativa do Market Analysis ${ }^{76}$ apresentou como as estratégias de comunicação sobre sustentabilidade sensibilizam os consumidores. A grande maioria percebe a imagem de uma empresa “sustentável” em primeiro lugar, a partir do desenvolvimento e divulgação de projetos ambientais e, em segundo lugar, a partir das campanhas de responsabilidade social. Esses exemplos mostram que os consumidores estão desempenhando um papel mais ativo nas relações de consumo, exigindo transparência e realismo das estratégias de marketing e das mensagens publicitárias sobre diferentes produtos e serviços.

Para relacionar essas tendências do marketing com a abordagem da experiência elementar, utilizamos, nessa etapa, os pontos evidenciados por Giussani (2009) no capítulo IV: o eu-em-ação, o compromisso com a vida, aspectos do compromisso, dupla realidade e redução materialista. Para cada um desses pontos, escolhemos campanhas publicitárias do ano de $2013^{77}$, que inserem-se na categoria Serviço Comunitário ${ }^{78}$ e colaboram dentro das estratégias de marketing, para a comunicação institucional das empresas, produtos e prestadores de serviços.

Como esse estudo ainda é uma reflexão sobre o tema, não existe evidências científicas de sua eficácia e aplicabilidade. A ideia é oferecer uma nova possibilidade de abordagem do

\footnotetext{
${ }^{76}$ Disponível em < http://www.ideiasustentavel.com.br/2012/07/os-significados-da-sustentabilidade-empresarialpara-o-consumidor/ acessado em 12 de abril de 2014.

${ }_{77}$ Campanhas disponíveis no site < http://prcb.espm.br/ > acessado em 3 de março de 2014.

${ }^{78}$ A denominação dessa categoria insere-se na literatura acadêmica da área de marketing e comunicação.
} 
conceito de consumidor, partindo da hipótese de que "somos todos consumidores" ( Kotler, 2010, p. 36).

\section{1.- O "eu-em-ação"}

Para entender o percurso de conhecimento da experiência elementar, Giussani (2009) nos orienta a ter uma atenção especial com a questão do ser humano e suas exigências constitutivas de justiça, de felicidade, de amor e de liberdade. Buscar o sentido de verdade nos relacionamentos, nas experiências, no significado da vida humana são atitudes efetivas para se percorrer esse caminho em busca da experiência de ser humano.

Nós fomos feitos para a verdade, entendendo por verdade a correspondência entre consciência e realidade, que vimos ser a natureza do dinamismo racional. Vale repetir que o verdadeiro problema, no que concerne à busca da verdade sobre os significados últimos da vida, não é o de uma certa inteligência que se faça necessária ou o de um esforço especial ou, ainda, o de meios excepcionais para alcançá-la. A verdade última é como encontrar uma linda coisa no nosso próprio caminho: só a vemos e reconhecemos se estivermos atentos. O problema, portanto, é essa atenção (Giussani, 2009, p. 59).

A questão que surge nesse ponto é: Como proceder, em busca dessa verdade na dinâmica das relações do cotidiano? Mais especificamente, como proceder para encontrar essa verdade ao analisarmos o consumidor enquanto pessoa, inserida nas relações de consumo, sem desrespeitar as exigências de justiça, amor, liberdade e felicidade?

Quando Giussani (2009) afirma que "partir de nós mesmos" pode provocar um erro de interpretação se for descolado da realidade cotidiana, também sugere que, ao "olhar em ação", em busca desse "eu", de "nós mesmos", implica em resgatar o humano das relações e atividades diárias.

Nesse ponto, pode-se constatar que é necessária uma postura ética profissional diante, por exemplo, da necessidade de se criar estratégias que "manipulem" o comportamento do consumidor, uma vez que o profissional que cria essas estratégias também é um consumidor.

O "eu-em-ação", proposto pelo autor, nos orienta para que "os fatores que nos constituem emergem, portanto, quando nos observamos em ação. É aqui que aparecem os elementos sustentadores daquilo que é o mecanismo, o sujeito humano" (Giussani, 2009, p. $60)$. 
Nesse sentido, o profissional de marketing, ao voltar-se para si, identifica um sujeito em movimento que também é um consumidor, e que vivencia na prática todas as angústias e alegrias relacionadas ao consumo. Então, essa atitude no dia a dia do profissional pode ser "praticada e ensinada" no seu processo de formação, no ambiente acadêmico, e mesmo no seu ambiente de trabalho. Isso evidencia uma retomada da consciência ética e crítica diante da "totalidade dos fatores". Alguns autores da área de Marketing já enfatizam essa postura profissional:

Acreditamos que é hora de colocar um ponto final na dicotomia entre profissional de marketing e consumidor. Os profissionais de Marketing responsáveis por qualquer produto ou serviço devem perceber que também são consumidores de outros produtos e serviços. Os consumidores também podem estar cientes de que devem fazer uso do marketing no dia a dia para convencer seus companheiros consumidores. Todos nós somos tanto profissionais de Marketing quanto consumidores. O Marketing não é apenas algo que seus profissionais fazem com os consumidores. Os consumidores também estão fazendo Marketing para outros consumidores (Kotler, 2012, p. 36).

A área de Marketing no Brasil é regida por princípios éticos, conforme o código de ética da ABMN - Associação Brasileira de Marketing e Negócios ${ }^{79}$ em sintonia com os demais órgãos e entidades de classe. A atividade publicitária também é regida por princípios éticos, conforme a lei $4.680^{80}$, de 1968 , que regulamentou a existência da área como prática profissional. Os princípios éticos estão descritos no Art. $17^{81}$ do Decreto 57.690/1966 que determinou que esta prática profissional, por atender a prestação de serviços que envolvem consumidores, deve atentar para uma legislação específica que regulamenta essa prática. Segundo esse artigo, a atividade publicitária tem o dever de exercer seu papel de divulgar produtos e serviços, tendo em vista o crescimento das empresas e a expansão da economia, mas com regras específicas para não difamar, enganar ou ludibriar o consumidor.

O princípio da verdade, uma exigência fundamental do ser humano, deve ser respeito devendo ser também a base para o exercício da atividade profissional do publicitário e do profissional de marketing. Mas como reconhecer a verdade nesse contexto?

\footnotetext{
${ }^{79}$ Disponível em <http://abmn.com.br/codigo/profissionais.asp > acessado em 13 de abril de 2014.

${ }^{80}$ De 18 de junho de 1965 - dispõe sobre o exercício da profissão de publicitário e de agenciador de propaganda e dá outras providências.

${ }^{81}$ Art. 17. A Agência de Propaganda, o Veículo de Divulgação e o Publicitário em geral, sem prejuízo de outros deveres e proibições previstos neste Regulamento, ficam sujeitos, no que couber, aos seguintes preceitos, genericamente ditados pelo Código de Ética dos Profissionais da Propaganda a que se refere o art. 17, da Lei 4.680, de 18 de junho de 1965. Disponível em 〈http://www.planalto.gov.br/ccivil_03/leis/14680.htm> acessado em 13 de abril de 2014
} 
No relacionamento com a vida como um todo, carregamos o movimento de querer conhecer o que as coisas são que é justamente a pergunta pela verdade (Giussani, 2000, 2002). O que é isso que estou conhecendo? O que é isso que está diante de mim? São perguntas que surgem no contato com o real, seja nos relacionamentos particularmente significativos, seja no simples abrir dos olhos pela manhã, quando esperamos que algo de novo aconteça, quando esperamos encontrar a verdade (Cury et. al, 2007, p. 3).

A exigência de verdade estabelece um vínculo com "aquilo que identificamos como correspondente", ou seja, "antes de falar de verdade, tem que se falar de razão" (Cury et. al, 2007, p. 1). E a razão segundo Giussani (2009) é a "capacidade de dar-se conta do real segundo a totalidade dos fatores".

Usar a razão, segundo essa perspectiva, faz o homem, o profissional em suas atividades, perguntar-se sobre si e sobre a realidade que o cerca. Se alguém, por exemplo, nos ofende, ou nos chama a atenção, e ficamos irritados com essa situação, o mau uso da razão pode levar a nos distanciar daquela pessoa. Do contrário, ao nos depararmos com uma situação equivocada, que exige uma postura de entendimento do que realmente está acontecendo, o uso da razão de uma forma mais completa pode nos levar à aproximação do princípio de verdade, daquilo que nos corresponde enquanto pessoas.

$\mathrm{Na}$ atividade de marketing, posturas profissionais equivocadas e estratégias mal elaboradas, enfatizando o consumo através de propaganda enganosa, por exemplo, colaboram para a quebra desse princípio de verdade, que faz parte da prática profissional e que faz parte dessas exigências fundamentais do ser humano. A consciência do profissional de que existe um "eu-em-ação", e de que também é um consumidor, colabora para a formação de profissionais que não apenas interpretam os princípios éticos da profissão, mas que também vivenciam essa postura em suas atividades diárias. O compromisso com as exigências do mercado, nesse contexto, pode levar alguns profissionais a agirem de outro modo, mas a retomada da consciência crítica, a partir desse conceito, pode colaborar para uma atitude mais razoável.

\section{2 - O compromisso com a vida}

O compromisso com a vida para Giussani (2009, p. 62), evidencia que "quanto mais alguém está comprometido com a vida, tanto mais percebe também em cada experiência os próprios fatores da vida". 
Os consumidores aderem aos produtos e serviços oferecidos pelas campanhas publicitárias se forem motivados pelo que foi apresentado e se necessitarem daquele produto ou serviço para se alimentar, se abrigar, se sentir seguro, etc. Essa é a razão consciente do ato de consumir. Porém, quando a estratégia é direcionada para manipular esse consumidor, deixando de lado a questão fundamental de que os consumidores também são pessoas, evidenciando apenas as questões mercadológicas, podem acontecer distorções nessa atividade. Um exemplo disso é o incentivo ao consumo de bebidas alcoólicas em eventos musicais direcionados a jovens, como shows de música ao ar livre. Os patrocinadores desses grandes eventos, em sua maioria, são empresas do setor de bebidas alcoólicas e, obrigatoriamente, nas suas mensagens apresentam os dizeres de "se beber não dirija". Ao mesmo tempo em que assumem uma posição real diante da problemática do consumo de bebidas e do fato de dirigir embriagado, incentivam o consumo durante um evento, onde milhares de jovens e pessoas de todas as idades estão presentes e, muitas delas, conduzindo os próprios veículos.

A relação entre o consumo de bebidas alcoólicas e o prazer proporcionado por essa prática é tema de muitas campanhas publicitárias e discussões em diferentes áreas do conhecimento. A influência das propagandas de bebidas alcoólicas nos momentos em que o consumidor está mais propício a consumir gera "esse mesmo reflexo condicionado: vejo lembro - quero ansiosamente - me sinto recompensado momentaneamente" (Sawaya, 2013, p. 58). Essa pesquisadora da área da neurofisiologia nos alerta para o crescente consumo de cerveja, baseado numa estratégia de marketing que sugeriu uma mudança de hábito de consumo de bebidas alcoólicas entre os brasileiros:

A cerveja nasceu em países europeus onde a baixa temperatura impedia a produção de uva e vinho. Além de aumentar a temperatura corporal, é diurética, desidrata e, portanto, aumenta a sede. Foi, justamente, desenvolvida em climas frios após a descoberta da sua capacidade de aquecer o corpo e fornecer energia. Mas uma estratégia de marketing extremamente bem-sucedida da indústria de bebidas conseguiu mudar o hábito de beber cachaça e introduzir a cerveja através da invenção da cerveja "estupidamente" gelada; o que nos países de origem dessa seria inaceitável. Assim, passou a vender a sensação refrescante, o copo gelado, juntamente à cerveja. A maciça propaganda com mulheres e lugares bonitos, jovens em férias, direcionada ao público masculino e mais recentemente ao jovem e feminino impôs um contexto social que tornou a cerveja um ícone para se encontrar com os amigos e a bebida das férias de verão em nossas praias tropicais. Mas, poderíamos nos perguntar, os sinais metabólicos internos do aumento desagradável da temperatura corporal, assim como da sede não são percebidos e levados à consciência? Sim, mas o contexto social e o aprendizado durante a juventude, as ocasiões agradáveis em que é consumida tornaram-se o estímulo predominante ou saliente para seu consumo obliterando os sinais metabólicos (Sawaya, 2013, p. 59). 
Porém já existem anunciantes, mais conscientes de seu papel na sociedade que colaboram de uma forma diferenciada para mudanças de comportamento, apesar do assédio constante das campanhas da indústria de bebidas alcoólicas.

Um exemplo de uma estratégia mercadológica diferenciada foi desenvolvido por um portal de entretenimento da cidade de Belo Horizonte, estado de Minas Gerais em parceria com bares e restaurantes locais. A capital mineira é tradicionalmente conhecida como a "capital mundial dos bares".

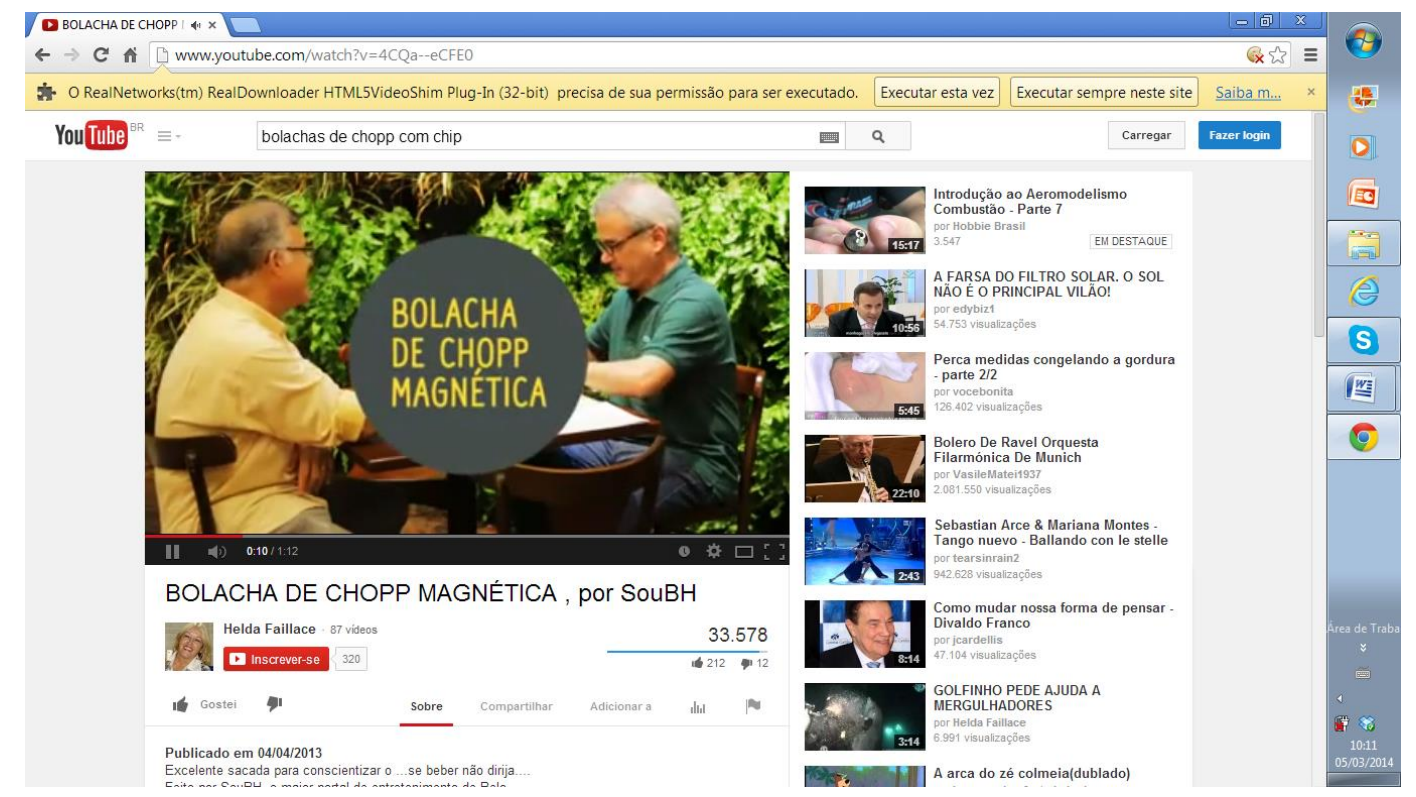

Figura 4: Retirado do World Wide Web $<$ http://www.youtube.com/watch?v=4CQa--eCFE0 $>$ em 3 de março de 2014.

Para essa campanha foram desenvolvidas "bolachas de chopp", nas quais foi implantado, no miolo das bolachas, um chip com polos opostos e, embaixo da tulipa (copo específico para essa bebida), outro chip. O consumidor, ao tentar colocar a tulipa sobre a bolacha, dependendo do lado em que esta se encontrava, poderia repelir ou não o fundo do copo. Do lado que repelia estava o texto "se beber não dirija" e do outro lado, aquele em que os polos se encontravam, estava o texto "Se você for beber use um taxi e terá $10 \%$ de desconto na conta do bar". O anunciante, o portal de entretenimento Sou- $\mathrm{BH}^{82}$, em parceria com os bares e restaurantes, proporcionou com essa ação uma experiência de consumo diferente, utilizando as mensagens de conscientização sobre o consumo de bebida alcoólica. $\mathrm{O}$ resultado dessa atividade evidenciou a divulgação do portal e, também, a adesão de bares e restaurantes as campanhas de conscientização sobre o consumo de bebidas alcoólicas. Nesse caso pode-se afirmar que o anunciante se colocou no lugar do consumidor e apresentou o seu

\footnotetext{
${ }^{82}$ Disponível em < http://www.soubh.com.br/> acessado em 3 de março de 2014.
} 
compromisso em relação às questões que envolvem bebida e direção, sem deixar de divulgar os estabelecimentos comerciais de venda de chopp da cidade.

Trata-se de uma campanha que se aproxima do sentido de educar o consumidor sobre um tema que se relaciona com a própria vida dele: [...] "trazendo a pessoa à experiência" (Giussani, 2009, p.59), e completou : "Por tudo o que dissemos, fica claro que quanto mais alguém está comprometido com a vida, tanto mais percebe também em cada experiência, os próprios fatores da vida".

\section{3 - Aspectos do Compromisso (a tradição)}

Outro ponto evidenciado por Giussani (2009) na teorização da experiência elementar é o nosso compromisso com a tradição. A tradição para o autor reflete um sentimento de pertença do homem à sua natureza enquanto pessoa.

[...] a tradição é, pois, a complexa herança com a qual a natureza arma a nossa pessoa. Não porque devamos fossilizar-nos nela, mas porque temos de desenvolver - até o ponto de mudar, e profundamente - aquilo mesmo que nos foi dado (Giussani, 2009, p. 64).

O autor ressalta a importância da tradição como primeiros ensinamentos, como aquilo que "me foi dado". Desprezar essa característica humana pode ser profundamente prejudicial ao seu desenvolvimento enquanto pessoa. Giussani fala numa "urgência de uma lealdade para com a tradição: ela é requerida por um compromisso global com a existência”.

A tradição da qual fala o autor está presente no sentido da moralidade, uma das três premissas abordadas nesse trabalho no capitulo três. Para o autor, a palavra moralidade vem de mos (comportamento) e se define como a atitude que temos diante de um problema. Como reflexo de nossa tradição e de nosso aprendizado, podemos ter reações diferentes diante das experiências diárias. Podemos socorrer um enfermo ou um mendigo na rua, por exemplo, se isso realmente nos foi concedido como ensinamento. Podemos trabalhar de maneira ética se isso nos foi ensinado no processo de formação. Giussani (2009, p. 54) afirma:

O centro do problema é realmente uma posição justa do coração, uma postura exata, um sentimento no seu devido lugar, uma moralidade. [...] Se a moralidade está no definir-se de uma postura justa, também esta é determinada pelo objeto em questão. Se considerarmos uma pessoa que trabalhe dando aulas e outra que trabalhe no caixa de uma agência bancária, 
a primeira deve ser moral ao ensinar; a segunda, ao descontar os cheques e ao depositar o dinheiro nas contas correntes: são duas dinâmicas diferentes.

Mahfoud (2012, p. 119) completa:

Moralidade: um posicionamento diante de algo, uma postura justa. É justo o posicionamento que tem a ver com a totalidade dos fatores em questão: referente ao sujeito e ao objeto. Esse justo não pode ser definido genérica ou abstratamente, mas precisa se adequar ao específico sujeito e ao específico objeto.

Entre as novas tendências do marketing contemporâneo a questão social, no sentido de se inserir práticas que valorizem o comprometimento de empresas e anunciantes com o contexto sócio econômico, cultural, social e ambiental, tem sido amplamente utilizada como estratégia mercadológica. Os anunciantes, ao reafirmarem essa posição de que estão "engajados" em causas que valorizam a vida, o meio ambiente, e as populações carentes, se posicionam a favor de uma atitude moral diante do compromisso com a vida e com seu trabalho.

É importante afirmar que, em alguns casos, essa atitude pode ser usada de forma reducionista e materialista pelos estrategistas de marketing, apenas como valorização da sua imagem institucional, mas evidencia-se um movimento dos próprios profissionais para que essa prática se torne mais positiva e que resgate no consumidor a tradição de cultivar antigos hábitos e costumes, que se perderam ao longo dos anos.

Para exemplificar, analisamos uma campanha que está inserida nas tendências do marketing experiencial e cybermarketing, e que provoca o cliente a mudar de hábito e resgatar antigos comportamentos, diante de um aplicativo disponibilizado via wi-fi, num bar estilo espanhol localizado em uma grande capital brasileira. 


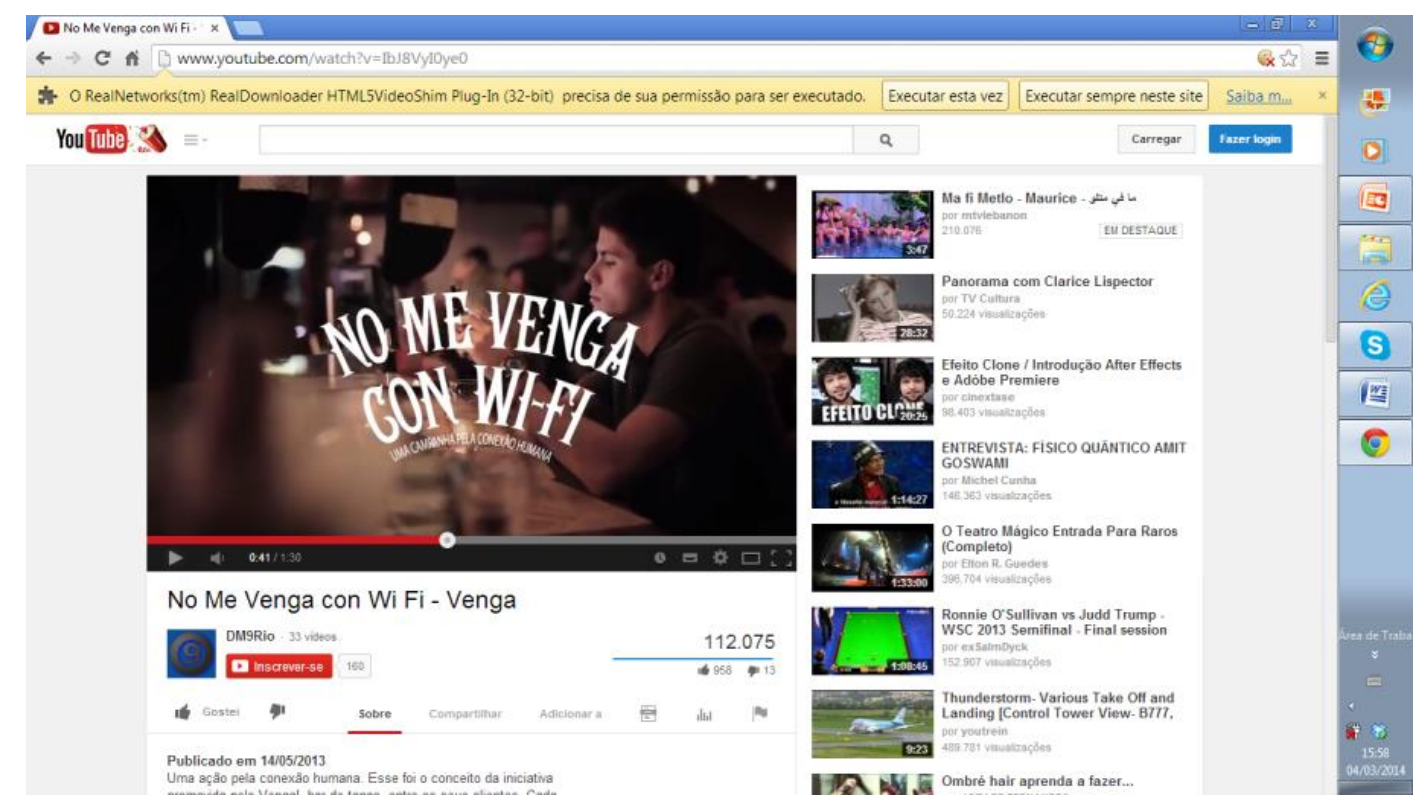

Figura 5: Retirado do World Wide Web < http://www.youtube.com/watch?v=IbJ8VyI0ye0 $>$ acessado em 3 de março de 2014.

A ideia da ação da campanha "Não me venga com wi-fi" surgiu a partir da constatação de que os bares e restaurantes são lugares que proporcionam o encontro de amigos para um bate-papo, uma conversa sobre trabalho e/ ou um ambiente de convivência. Com o advento dos celulares e da possibilidade de acessar continuamente os recursos da internet e as redes sociais, cada vez mais o uso desses aparelhos nas mesas dos bares tem sido uma constante, o que, em algumas situações, pode provocar situações de desconforto para aqueles que não tem esse hábito adquirido. As pessoas hoje se socializam via wi-fi, de modo virtual, e as chamadas conexões humanas estão cada vez mais escassas.

Diante desse comportamento, o proprietário do bar, através de uma campanha criada por uma agência de publicidade, programou alguns roteadores dentro do estabelecimento para que, ao serem acessados, mostrassem aos clientes frases como "Ah! Larga o celular!”, "Curta o momento! Uma dica do Venga". A palavra "Venga" é o nome do bar que tem estilo espanhol.

A ação combinou os recursos da tecnologia mobile (cybermarketing) e a experiência de consumo dos frequentadores do bar (Marketing experiencial), com o intuito de resgatar costumes e hábitos tradicionais, tais como: o bate-papo com os amigos e o encontro. Foi uma ação que envolveu uma mensagem educativa, mas que evidenciou um posicionamento real diante de uma situação do cotidiano do anunciante e dos consumidores do bar. A estratégia para trabalhar o conceito de consumidor, seu posicionamento e o comportamento de compra diante da situação de "não usar o wi-fi" foi criada para enfatizar as relações de amizade e de encontro que acontecem num bar. 


\section{4 - Aspectos do Compromisso (o presente)}

Sobre o "olhar" direcionado ao presente como forma de compreender os fatores dos quais é constituído, Giussani $(2009$, p.66) evidencia que o presente é o "lugar enigmático e esplêndido, da liberdade, a energia que manipula o conteúdo do passado, liberando sua criatividade responsável”. Olhar o presente significa vivenciar, estar em constante atenção para aquilo que nos foi dado enquanto pessoas.

As novas tendências do Marketing contemporâneo, relacionadas às questões sociais, sinalizam para essa necessidade de olhar o presente e a realidade nas relações de consumo. As empresas engajadas em causas sociais lançam campanhas que tem como objetivo resgatar no dia a dia das pessoas uma tomada de atitude e de compromisso em relação às questões sociais, ambientais e culturais.

Um relatório publicado pelo Worldwatch Institute ${ }^{83}$, no ano de 2012 , apontou que “ $16 \%$ das pessoas são responsáveis por $78 \%$ do que é consumido no mundo. Se os habitantes do planeta consumissem conforme aquela elite em sua totalidade, seriam necessários cinco planetas Terra para sustentar a todos". Diante dessas questões que impactam a vida das pessoas, a comunicação, o marketing e a propaganda tem papel decisivo na mudança de hábitos e atitudes com relação ao consumo consciente. As empresas, através de diferentes ações e campanhas tem um compromisso real com o consumidor, auxiliando-o na tomada de decisões no ponto de venda. Segundo essa perspectiva, não basta dizer apenas "sou uma embalagem reciclável" ou "este produto é biodegradável". A empresa deve explicar de forma clara e precisa, qual é realmente o impacto provocado no meio ambiente devido ao uso ou não desse tipo de produto.

Como exemplo dessa atitude de educação e de compromisso com a vida e o presente, a empresa Colgate, tradicional fabricante de produtos para higiene pessoal, apresentou uma campanha desenvolvida por uma agência de propaganda que realiza seus trabalhos de comunicação no Peru, sobre a conscientização quanto à economia de água durante a prática diária de higiene pessoal, como é o caso ao se escovar os dentes.

O filme exibe um rapaz que ao escovar os dentes, deixa escorrer por algum tempo a água. Nesse intervalo de tempo em que o rapaz ainda está escovando e não usa o líquido que está escorrendo pela torneira aberta, outras mãos, representando outras pessoas, utilizam o líquido para encher um copo de água, outra para encher um recipiente, outra para lavar uma fruta e, por fim uma garota bebe água. A ideia é mostrar que "enquanto você deixa uma

\footnotetext{
${ }^{83}$ Disponível em: < http://www.worldwatch.org/> acessado em 3 de março de 2014.
} 
torneira aberta para escovar os dentes por muito tempo, pode gastar até 10 litros de água. Isto é mais do que muitas pessoas no mundo tem por um mês inteiro".

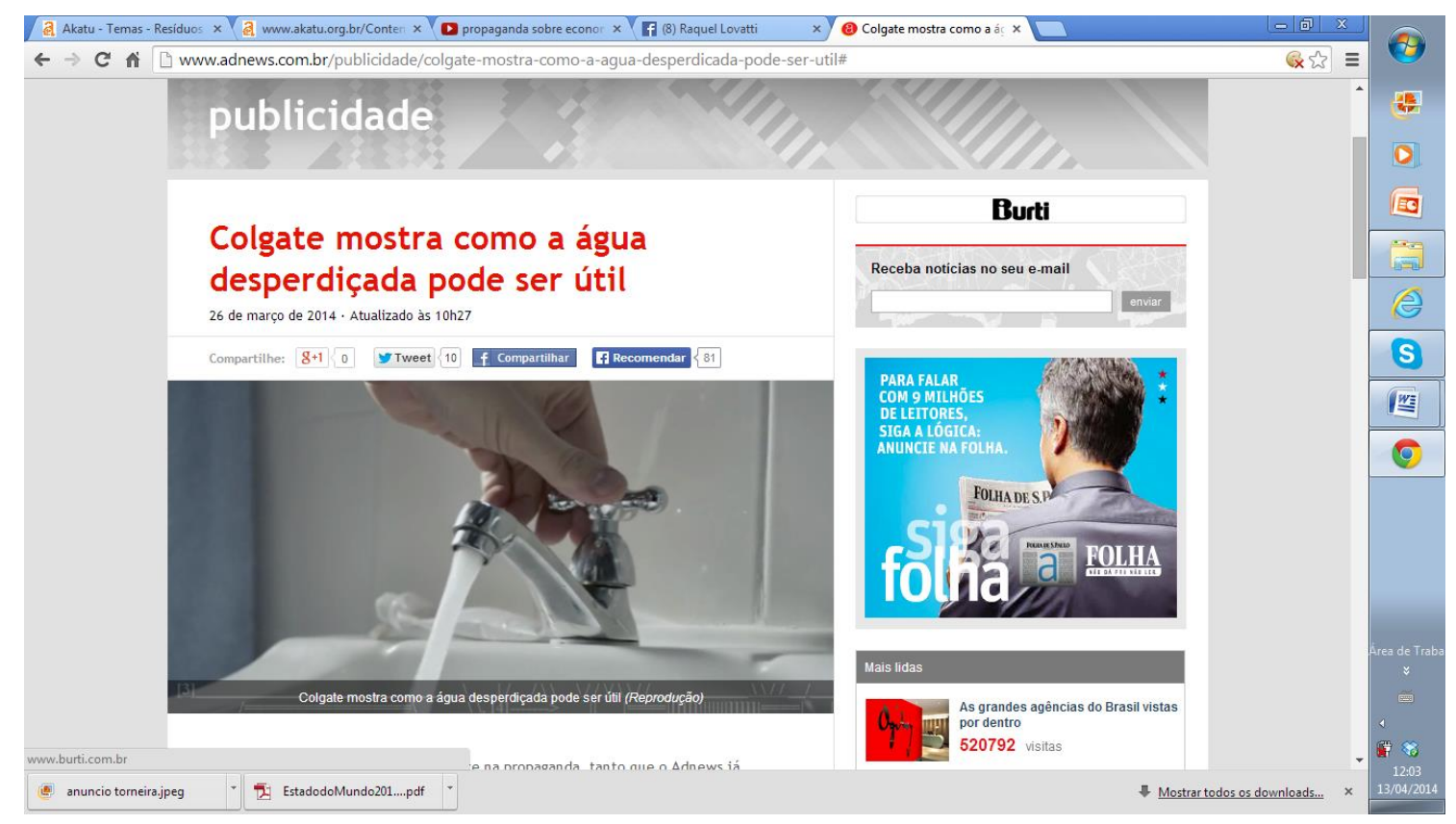

Figura 6: Retirado do World Wide Web <http://www.adnews.com.br/publicidade/colgate-mostra-como-a-aguadesperdicada-pode-ser-util\# > acessado em 13 de abril de 2014.

A campanha tinha como principal objetivo alertar o consumidor peruano sobre o fato de que a água desperdiçada poderia ser útil, e que através de uma atitude simples como "fechar a torneira ao escovar os dentes" poderia representar economia de água. Não fechar a torneira parece ser um hábito incorporado ao nosso dia a dia e, muitas vezes, passa despercebido pela maioria dos consumidores.

Estabelecendo um paralelo com a premissa da moralidade e do compromisso com a vida, segundo Giussani, observamos nessa campanha a necessidade de preservar o meio ambiente e educar consumidores sobre o consumo consciente de produtos. A fabricante de produtos para higiene pessoal, como parte de sua política de responsabilidade social, aderiu à campanha de conscientização do uso da água, associando a utilização de seu produto a uma questão importante para a tomada de consciência quanto ao uso racional de recursos naturais, como é o caso da água. 


\section{5 - Dupla realidade e redução materialista}

Atento às experiências da realidade e da experiência original como ser humano, o homem se vê diante de dois tipos de realidade: uma mensurável ou mutável, e outra que não pode ser medida, imutável.

$\mathrm{O}$ que se mostra e se evidencia como parte da realidade presente, que consegue ser transformado em algo concreto, é mensurável, é um fenômeno que faz parte do conhecimento e se apresenta como uma realidade. Nas palavras de Giussani (2009, p. 67): "Se eu deixasse sobre uma mesa um fragmento de rocha, mesmo da mais resistente, e daqui a um bilhão de anos alguém pudesse observá-lo, iria encontrá-lo profundamente modificado. [...] Trata-se da materialidade".

O que não é mensurável e está, por exemplo, no nível das exigências fundamentais, como o sentimento da bondade, não poderia ser medido e modificado com o tempo. É algo que nos constitui enquanto pessoas fortalecendo nossos relacionamentos diários. A constatação de que algo externo a nós, que faz parte da realidade (o que podemos ver presenciar e tocar), nos orienta no caminho para a descoberta da experiência original e elementar da descoberta do humano, presente em nosso dia a dia, reforça a ideia da dupla realidade a que somos expostos em nossos relacionamentos diários. A ameaça da redução materialista, de relacionar a experiência humana diária apenas àquilo que é concreto e, distorce o nosso entendimento de que o original e único que fundamenta a experiência humana, parte de algo que lhe é dado, que é parte de sua vida, que é a própria consciência de seu ser enquanto pessoa.

Um exemplo de campanha que se aproxima da descrição da dupla realidade de Giussani, e enfatiza a importância da ideia de bondade nos relacionamentos humanos, foi criada por uma empresa de seguros tailandesa. A campanha apresenta o dia a dia de um jovem que ajuda as pessoas com gestos simples de caridade: a doação de alimentos, pequenas quantias em dinheiro, o auxílio a uma pessoa idosa para conduzir um carrinho usado para a venda de alimentos. Esses gestos são repetidos diariamente até que um dia o jovem consegue observar mudanças concretas nas pessoas que sempre ajudou em suas atividades. O gesto mais surpreendente é o da criança que recebia esmolas na rua com sua mãe, e acaba conseguindo voltar para a escola, com a ajuda e o gesto de bondade do jovem. 


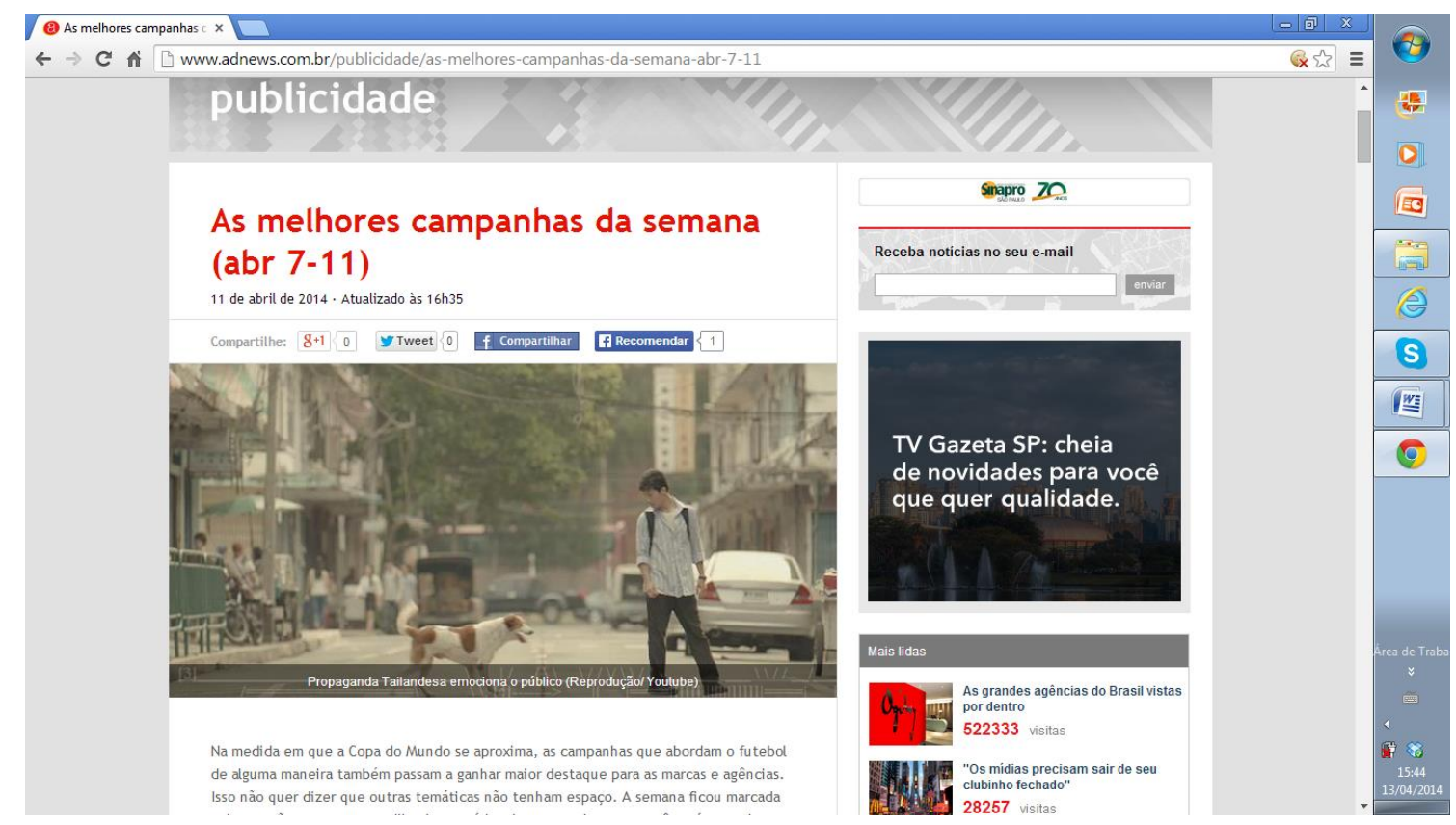

Figura 7: Retirado do World Wide Web < http://www.adnews.com.br/publicidade/as-melhores-campanhas-dasemana-abr-7-11> acessado em 13 de abril de 2014.

Essa campanha, que aborda as temáticas sociais, relata a experiência de bondade do jovem em situações de seu dia a dia. A ideia da companhia de seguros era revelar o que o jovem recebia em "troca" desses gestos de bondade, que era o sentido que ele próprio atribuía à vida: um sentimento de felicidade que os bens materiais não lhe proporcionavam, isto é, um sentimento de segurança.

No pensamento de Giussani (2009, p. 68):

A observação que o sujeito faz de si mesmo em ação lhe mostra, então, que o seu eu é composto de duas realidades diversas. Tentar reduzir uma à outra seria negar a evidência da experiência que as apresenta diversas. Essas duas realidades com características irredutíveis podem ser chamadas de muitos modos: foram denominadas matéria e espírito, corpo e alma. Porém, o importante é considerar firmemente a irredutibilidade de uma à outra.

A propaganda enfatizou um sentimento humano que só consegue ser observado a partir da experiência que emerge e toca um sentimento mais profundo que é a bondade. $\mathrm{O}$ anunciante chamou a atenção para a falta de cuidado que as pessoas tem com outras, que mesmo não sendo conhecidas, fazem parte do cotidiano e passam muitas vezes despercebidas. Ao evidenciar a realidade que se apresentava diante de seus olhos - as pessoas que o jovem ajudava com pequenos gestos, sem refletir ou cobrar se aquelas pessoas seriam merecedoras de suas atitudes, o jovem realizou uma experiência original e única, um gesto de gentileza. 
Nesse exemplo, a mensagem do anunciante era resgatar o sentimento humano da bondade que se apresenta na vida das pessoas, e que faz parte das características do ser humano. A imagem da marca da companhia de seguros refletiu uma preocupação com as relações sociais e humanas.

Ao analisarmos essas campanhas e sua relação com os temas escolhidos, a partir do conceito de Experiência elementar de Giussani (2009), pudemos perceber que o conceito de consumidor abordado através de diferentes estratégias mercadológicas, se aproxima do foco no "humano que emerge das relações" e experiências diárias. Nos casos apresentados, os estrategistas em marketing, preocupados com as necessidades de mudanças no posicionamento da área frente aos dilemas humanos, propuseram ações, campanhas e abordagens mais específicas. A ideia nessas campanhas é abordar os temas da preservação ambiental, da responsabilidade social e das desigualdades sociais de uma forma "real".

A discussão a partir da interface entre as áreas de Marketing e Psicologia, e do percurso proposto por Giussani (2009), sinalizam para a possibilidade de, na área mercadológica, se abordar o consumidor de uma forma diferenciada, respeitando suas características humanas. Para a área de Marketing, o desafio é evidenciar que as antigas estratégias focadas na "manipulação" e na "indução ao consumo", podem ser substituídas por mensagens mais dirigidas às necessidades reais dos produtos e serviços. Os estudos psicológicos que auxiliam na prática da área de Marketing são importantes e necessários para o desenvolvimento da atividade, porém, diante das novas realidades apresentadas e da urgência em discutir os temas relacionados a consumo e consumidor, esses estudos demandam os suportes filosóficos, antropológicos e humanos como, por exemplo, o da abordagem da Experiência elementar. 


\section{6 - CONSIDERAÇÕES FINAIS}

Um dos temas mais desafiadores do século XXI diz respeito ao aumento do consumo de produtos considerados descartáveis e dispensáveis para o dia a dia das pessoas, diante do aumento da pobreza e das mazelas sociais de mais de $60 \%$ dos habitantes do planeta. Frente ao avanço da tecnologia e da velocidade de informação da sociedade capitalista contemporânea, o homem vive o dilema de "frear" o seu ímpeto consumista e retomar a consciência de que "algo deve ser feito" para que as futuras gerações resgatem, na medida do possível, experiências de consumo baseadas nas suas necessidades reais e não nas práticas impostas pelas estratégias de mercado, de modo que isso reverta numa distribuição mais justa e humana de recursos e riquezas.

A sociedade capitalista, considerada um dos "motores" das grandes mudanças econômicas e sociais do homem moderno, tem sido criticada pela forma como conduziu os avanços tecnológicos e a expansão de seus parques fabris nos pontos mais distantes do planeta. A expectativa é que, para o futuro, aconteça uma tomada de consciência empresarial no sentido de projetar para as próximas gerações a esperança de melhoria na qualidade de vida, a partir de mudança significativa no contexto organizacional das empresas de diferentes setores.

Nesse contexto, a atividade de marketing também faz parte dessa retomada de consciência econômica, social e empresarial, na medida em que colabora, através do desenvolvimento de estratégias específicas, para a consolidação das vendas e dos recursos para empresas que investem em novos produtos e serviços. O ponto de partida, talvez, seja repensar as estratégias e decisões mercadológicas desenvolvidas para diferentes empresas. Um ponto importante é evidenciar que, no centro de suas decisões, está o consumidor, uma pessoa que consome, indaga, indica e compra os produtos e serviços oferecidos diariamente no mundo inteiro, em diferentes sociedades.

A presente pesquisa surgiu da necessidade de se estabelecer um diálogo mais aprofundado com diferentes áreas das ciências humanas, tendo em vista que a atividade de marketing necessita de aprofundamentos e estudos sobre o conceito de consumidor no mundo contemporâneo. Ao compreender como teorias da psicologia contribuíram para a formação do conceito de consumidor na atualidade, em especial a proposta da Experiência elementar, que se fundamenta em uma concepção de pessoa humana, buscamos trilhar um caminho que fornecesse subsídios teóricos e práticos tendo em vista a formação acadêmica do graduando em Publicidade, Propaganda e Marketing. 
Considerando as naturezas distintas das áreas em questão (Psicologia e Marketing) esses estudos e aprofundamentos só foram possíveis porque o objeto central de nossa pesquisa foi a "pessoa". O conceito de pessoa evidenciou-se nessas áreas, a partir do reconhecimento de que o ser humano considerado como "centro" das abordagens e atividades dessas áreas, pode representar uma escolha importante e necessária para as discussões que envolvem os temas relacionados à vida psíquica, ao cotidiano e ao contato com a realidade no dia a dia profissional e pessoal.

Através do levantamento histórico das áreas de Marketing e da Psicologia do consumidor, observamos a importância da contribuição da psicologia e dos estudos psicológicos para o fortalecimento de ambas as áreas e do comportamento do consumidor. Esses estudos forneceram pesquisas comportamentais e experimentais de grande importância para a definição das estratégias mercadológicas de abordagem dos consumidores, bem como para a criação de campanhas publicitárias. O método histórico colaborou para que pudéssemos centralizar nossos estudos no conceito de consumidor e de como isso foi se estruturando, no percurso histórico da área de Marketing, a partir das escolas de pensamento em Marketing, da contribuição dos estudos psicológicos, e também através dos psicólogos que se aproximaram dos estudos sobre mercado e mídia.

Como resultado principal dessa aproximação entre as teorias da psicologia e do marketing, evidenciou-se que o conceito de consumidor, em diferentes épocas e contextos históricos, recebeu uma contribuição significativa dos estudos teóricos e experimentais de psicólogos, que passaram a estudar a psicologia e a sua aplicabilidade na publicidade. $\mathrm{O}$ casamento entre as áreas foi "quase" perfeito, no sentido de que, ao reconhecerem a importância de desvendar o comportamento do consumidor através do auxílio, das pesquisas psicológicas relacionadas a comportamento, consumo, hábitos e atitudes, além de práticas predatórias de mercado foram criadas, no sentido de manipular as "massas de consumidores" e tornar a atividade mercadológica o grande reforço da emergente economia capitalista americana.

No quadro apresentado no final do capítulo 2, relacionamos o conceito de consumidor segundo as diferentes escolas de pensamento em marketing com as teorias psicológicas presentes em cada contexto histórico. Essa análise ressaltou a forte aproximação entre as áreas e a valiosa contribuição dos estudos psicológicos para o desenvolvimento das estratégias de marketing.

Ao analisarmos as novas tendências do marketing contemporâneo e a possibilidade de abordar o consumidor como pessoa, nos apoiamos nessa nova proposta como sendo uma 
possibilidade importante e necessária aos estudos sobre mercado, frente às novas realidades que as populações dos países capitalistas enfrentam, decorrentes da distribuição desigual de rendas, da ênfase ao consumo e ao consumismo, dos problemas na formação dos profissionais de Marketing e Comunicação, assim como da degradação do meio ambiente fruto do avanço das tecnologias e da informação.

A ampliação da discussão sobre o conceito de consumidor nos aproximou da abordagem da Experiência elementar, numa tentativa de apresentar para a área de Marketing que trabalhar conceitos da área da Psicologia de forma utilitária, somente com o sentido de apropriação prática dessa área específica, no sentido de interpretar e desvendar comportamentos de consumo "descolados" de princípios filosóficos e humanos, pode induzir ao uso de técnicas e de formas não adequadas de abordagens mercadológicas, colaborando para as distorções de interpretação do trabalho da área.

O levantamento histórico dos conceitos de pessoa e experiência, a partir de estudos filosóficos e psicológicos, nos possibilitou enfrentar a temática da Experiência elementar e reconhecer que é possível discutir segundo as premissas do realismo, da razoabilidade e da moralidade sobre a dinâmica do conhecimento o conceito de consumidor no mundo contemporâneo, de forma crítica. As novas tendências da área já apresentam uma preocupação com as novas realidades onde estão inseridos os consumidores e a análise das campanhas apresentadas no capítulo 4 evidencia que, ainda sem o aprofundamento filosófico e humano, é possível direcionar os esforços de marketing e comunicação para uma abordagem do consumidor de uma forma mais individualizada e humana.

A conclusão desse trabalho levanta a hipótese de que a Experiência elementar, como uma abordagem antropológica filosófica, pode ser pertinente para se discutir o conceito de consumidor no mundo contemporâneo, a partir dos novos estudos de marketing que trabalham uma perspectiva mais humana para essa atividade. E ainda, tais práticas, podem auxiliar nos estudos e atividades relacionadas à psicologia e ao comportamento do consumidor, pois já são utilizadas por profissionais psicólogos como um método de trabalho clínico e terapêutico. ${ }^{84} \mathrm{~A}$ abordagem da Experiência elementar no contexto da formação acadêmica e profissional dos graduandos em Marketing e Comunicação poderia ser utilizada como uma forma de contribuições dadas pelas ciências humanas, colaborando para o desenvolvimento do espírito crítico e da sensibilidade ética desses profissionais, apesar das imposições do mercado, que direcionam as atividades de marketing e comunicação para contemplarem as expectativas de

\footnotetext{
${ }^{84}$ Mahfoud, M. (2012). Experiência Elementar em Psicologia. Aprendendo a reconhecer. Editora Universa e Artesã Editora, Brasília - DF.
} 
crescimento e aumento do consumo em suas estratégias para diferentes tipos de público consumidor.

Não se trata, evidentemente, de criar uma nova abordagem de marketing, a partir dos estudos da Experiência elementar, que constitui-se em mais uma escola de pensamento nas áreas mercadológicas e de consumo.

Trata-se de uma sugestão de mudança, talvez, no pensamento que impera na sociedade capitalista, e numa nova forma de interpretar as relações humanas no que diz respeito ao consumo e ao consumidor. Nesse sentido, o melhor local e momento para se "ensinar" essa nova postura profissional é, sem dúvida, o ambiente acadêmico, onde acontece o processo de formação dos profissionais.

Outra contribuição diz respeito à ampliação desses estudos para as áreas da Psicologia, do Marketing e da Comunicação, e ainda, para a formação de profissionais dessas áreas, que trabalham de forma interdisciplinar, com questões sobre o ser humano e sua relação com as práticas de consumo. 


\section{7 - REFERÊNCIAS}

Agnelo, G. M. C. (2009). (prefácio, pp. 11-15). In: Giussani, L. O senso religioso. Brasília: Ed. Universa.

Ajzental, A. (2010). História do Pensamento em Marketing. São Paulo: Saraiva.

Amatuzzi, M. M (2012). O descortinar de novas pistas para uma compreensão da pessoa. (prefácio, pp. 11-13). In: Mahfoud, M.. Experiência Elementar em Psicologia. Aprendendo a reconhecer. Brasília: Editora Universa e Artesã Editora.

Ambler, T. (2004). The new dominant logic of Marketing: views of the elephant. London: Centre for Marketing of London Business School. Working Paper, n. 04-903.

Bacellar, F. C. T. \& Ikeda, A. A. (2011). Evolução do Ensino de Marketing: Um breve histórico. Revista O\&S - Salvador, V. 18 - no. 58, p. 487-511 - Julho/setembro.

Bartels, R. (1970). Marketing Theory and Metatheory. Homewood, Illinois: Richard D. Irwin, Inc.

.(1976). The History of Marketing Thought. Disponível em: <http://people.missouristate.edu/ChuckHermans/Bartels.htm> acessado em 9 de dezembro de 2012.

Bechara, M. (2007). As fronteiras de atuação do Marketing entre a Administração e a Comunicação Social. Retirado do World Wide Web <http://www.mundomarketing.com.br> em 10 de dezembro de 2012.

Bernareggi, P. Fundamentação filosófica da Experiência elementar. Palestra proferida no Departamento de Psicologia da Faculdade de Filosofia e Ciências Humanas da Universidade Federal de Minas Gerais - 12 de março de 2007, como aula do curso "Experiência elementar em Psicologia II".

Blackwell, R. D. \& Miniard, J. F. E. (2005). Comportamento do Consumidor. São Paulo: Pioneira Thomson Learning.

Bock, A. M. B., Furtado, O. \& Teixeira, M. L. T. (2002). Psicologias: Uma introdução ao estudo de psicologia. São Paulo: Saraiva Editora.

Brandão, S.R. (2005). O método formativo de Alfonso López Quintás: Fundamentos filosóficos e experiência educativa. Tese de Doutorado. Faculdade de Educação da Universidade de São Paulo. 2005.

Brandão, S. R. (2006). A pessoa em Romano Guardini: um desafio à autonomia e desamparo do homem contemporâneo. Memorandum, 10, 147-156. Retirado em 13 de marçode2013, doWorldWideWeb:<http://www.fafich.ufmg.br/ memorandum/a10/bra ndao 01.htm. 134 
Brozek, J. \& Massimi, M. (ed.) (2001). Curso de Introdução à Historiografia da Psicologia: apontamentos para um curso breve. Memorandum, 1, 72-78.Retirado em 02 de maio de2011,doWorldWideWeb:<http://www.fafich.ufmg.br/ memorandum/artigos01/broz ek01. htm

Bueno, J. L. O. (2002). A consciência como ponto de partida. Paidéia, 12 (22), 83-87.

Cabral, P. (1986). Propaganda. A alquimia da Sociedade Industrial. São Paulo: Editora Nacional, 1986.

Cançado, C. R. X. , Soares, P. G. \& Cirino, S. D. (2011). O behaviorismo: uma proposta de estudo do comportamento. In: Jacó-Vilela, A. M., Ferreira, A. A. L. \& Portugal, F. T. Rio de Janeiro: Nau Editora.

Cavalcanti, T.(2012, 16 de setembro). Maquiagem para crianças gera polêmica. Folha de São Paulo, caderno C8 - Folha Ribeirão.

Coon, D. J. (1994). "Not a Creature of Reason": The Alleged Impact of Watsonian Behaviorism on Advertising in the 1920s. In: Todd, J. T. \& Morris, E. K. Modern Perspectives on John B. Watson and Classical Behaviorism. United States of America: Greenwood Press.

Cury,B.T; Gaspar,Y.E.; Maia,L.C. \& Mahfoud, M(2007). II Seminário Experiência elementar em Psicologia: Exigência de verdade. Realizado pelo LAPS, Depto. De Psicologia, Fafich, UFMG, Belo Horizonte.

Dichter, E. (1964). Handbook of consumer motivations.The psychology of the world of objects. Estados Unidos: Mc Graw - Hill.

Edward, W. (1961). Behaviral decision theory. Annual Review of Psychology, 12, p. 473498. In: Ajzental, A. (2010). História do Pensamento em Marketing. São Paulo: Saraiva.

Ferreira, A. A. L. \& Gutman, G. (2011). O Funcionalismo em seus primórdios: a psicologia a serviço da adaptação. In: Jacó-Vilela, A. M., Ferreira, A. A. L. \& Portugal, F. T. Rio de Janeiro: Nau Editora.

Fontenelle, I. A.(2008). Psicologia e Marketing: da parceria à crítica. Arquivos Brasileiros de Psicologia, v. 60, No. 2. Retirado do World Wide Web $<$ http//www.psicologia.ufrj.br> acessado em 3 de abril de 2013.

Gade, C. (1980). Psicologia do Consumidor. São Paulo: EPU - Editora Pedagógica e Universitária Ltda.

Gardenal, I. (2010,19 a 25 de abril). Tese revela mecanismos que fazem de pré-adolescentes reféns do consumismo. Jornal da Unicamp. Campinas, ano XXIV, no. 458.

Gaspar, Y.E \& Mahfoud, M(2006). Uma leitura histórica do conceito de experiência e uma proposta de compreensão do ser humano em seu caráter essencial: experiência elementare suas implicações para a Psicologia. In: III Seminário Internacional de Pesquisa e Estudos Qualitativos e V Encontro de Fenomenologia e Análise do 
Existir, 2006, São Bernardo do Campo. Anais do III Seminário Internacional de Pesquisa Qualitativa e V Encontro de Fenomenologia e Análise do Existir.

Guardini R.(2002). O encontro. In: Cogo, L. \& Chaves, C.C.C. (Orgs.) Curso de Extensão em Educação Infantil (pp. 204-212). Belo Horizonte. AVSI.

. (1963). O mundo e a pessoa. Ensaio para uma doutrina cristã do homem. Tradução de Fernando Gil. São Paulo: Livraria Duas Cidades.

Gérard, P. (1973). Introdução ao Marketing. Tradução de Francisco Guimarães. Petrópolis: Vozes.

Giussani, L. (2003). Realidade e Juventude: o desafio (M.J.M. Mendes, Trad). Lisboa: Diel. In: Mahfoud, M. (2012). Apresentação do curso Experiência elementar em Psicologia. . (2007). O caminho para a verdade é uma Experiência. São Paulo: Edições Tenacitas. In: Mahfoud, M. (2012). Apresentação do curso Experiência elementar em Psicologia. . (2009). O senso religioso. Brasília: Ed. Universa

Gracioso, F. (1975). Marketing: Uma experiência brasileira. São Paulo: Editora Cultrix.

Haugtvedt, C.P., Herr, P. M. \& Kardes, F. R. (ed.) (2007). Handbook of Consumer Psychology. New York: Lawrence Erlbaum Associates.

Hopkins, C. (1966). A Ciência da Propaganda. São Paulo: Editora Cultrix

Hunt, E. K. \& Sherman, H. J. (1990). História do Pensamento Econômico. Petrópolis: Ed. Vozes.

Ikeda, A. A., Campomar, M. C. \& Mendonça, P. S. M. (1997). Marketing sem fins lucrativos e Marketing de Ideias. $O$ caso de uma empresa governamental. Cadernos de pesquisa em administração. São Paulo, v. 1, n. 4, p. 37-50, 1. Semestre.

Keef, T (1988). Stress Coping Skills: on ounce of prevention in direct practice. In: Ramos, J. P. (1990). Motivação no Trabalho: Abordagens Teóricas. Psicologia - USP, S.Paulo, 1(2): 127-140.

Kotler, P. (1972). What consumerism means for market. Harvard Business Review, 50p. 48-5, Maio/Junho. In: Ajzental, A. (2010). História do Pensamento em Marketing. São Paulo: Saraiva.

. (2000). Administração de Marketing. São Paulo: Prentice Hall.

Kotler, P., Kartajaya, H \& Setiawan, I. (2010). Marketing 3.0 - As forças que estão definindo o novo marketing centrado no ser humano. Rio de Janeiro: Elsevier.

Linn, S. (2006). Crianças do Consumo: a infância roubada. Tradução: Cristina Tognelli. São Paulo: Instituto Alana.

Lopes, E. J., Lopes, R. F.F. \& Teixeira, J. F. A Psicologia Cognitiva Experimental cinqüenta anos depois: a crise do paradigma do processamento de informação. Revista Paidéia. V. 14, n. 29, 2004. 
Loureiro, I. (2011). Luzes e Sombras. Freud e o advento da psicanálise. In: Jacó-Vilela, A. M., Ferreira, A. A. L. \& Portugal, F. T. Rio de Janeiro: Nau Editora.

Mahfoud, M. \& Massimi, M. (2008). A pessoa como sujeito da experiência: contribuições da fenomenologia. Memorandum, 14, 52-61. Retirado em 13 de março de 2013, doWorldWideWeb:<http://www.fafich.ufmg.br/ memorandum/a14/mahfoudmassim i02.htm.

Mahfoud, M. (2012). Experiência Elementar em Psicologia. Aprendendo a reconhecer. Brasília: Editora Universa e Artesã Editora.

(2012). Material aula Curso: Experiência elementar em Psicologia: o eu e a abertura à alteridade.

. (2010). Métodos de Investigação em História da Psicologia. In: Psicologia em Pesquisa: UFJF. 4(02). Pp. 100-108. Julho-dezembro.

. (1998). A História das Ideias Psicológicas: uma viagem no tempo rumo aos novos mundos. In: Diálogos Metodológicos sobre Prática de Pesquisa. Ribeirão Preto: Legis Summa.

Massimi, M., Pacheco, P. R., Gontijo, S. \& Pimenta, V. D. S.(2002). Apostila da Disciplina de Teorias e Sistemas I - Modelos de Ciência e Pesquisa em Psicologia: confronto entre diversas perspectivas. Ribeirão Preto.

Massimi, M (2006). Psicologia e Cultura numa perspectiva histórica. Temas em Psicologia (vol.14, No. 2 ), 177-187.

Massimi, M. \& Mahfoud, M.(2007). A pessoa como sujeito da experiência: um percurso na história dos saberes psicológicos. Memorandum, 13, 16-31. Retirado em 13 de março de2013, doWorldWideWeb:<http://www.fafich.ufmg.br/ memorandum/a13/mahfoud massimi01.htm.

March,J. G. \& Simon, H. A.(1958). Organizations. New York: John Wiley \& Sons. In: Ajzental, A. (2010). História do Pensamento em Marketing. São Paulo: Saraiva.

Miranda, C. M. C. \& Arruda, D. M. O. (2004). A Evolução do Pensamento em Marketing: uma análise do corpo doutrinário acumulado no século XX. RIMAR - Revista Interdisciplinar de Marketing, v. 3, No. 1, p. 40-57, Jan/Jun.

Neto, J. M. B \& Wagner, C. (conselheiros). Representação no. 144/08, em recurso ordinário. (setembro/2008). São Paulo. Recuperado em 10 de outubro de 2012 da World Wide Web : $<\mathrm{http}: / /$ www.conar.org.br/> Petrini, J. C. (2005). Mudanças sociais e familiares na atualidade: reflexões à luz da história social e da sociologia. Memorandum, 8, 20-37. Retiradoem15deabrilde2013,doWorldWideWeb:<http://www.fafich.ufmg.br/ memorandu m/artigos08/petrini01.htm.

Petrini, J. C. (2012). Necessidades movem o mercado, exigências originais movem a pessoa e a história. (apresentação, pp.15-27). In: Mahfoud, M.. Experiência Elementar em Psicologia. Aprendendo a reconhecer. Brasília: Editora Universa e Artesã Editora.

Projeto criança e consumo (2010/2009 - Entrevistas realizadas entre novembro de 2009 e fevereiro de 2010). Por que a publicidade faz mal para as crianças. 
Refkalefsky, E. (2004). O que vende mais na Propaganda: razão ou emoção? In: NP Publicidade, Propaganda e Marketing no XXIII Congresso Intercom (2002). Manaus.

Rodrigues, C. D. R. Criança e Consumo - Análise de Livros sobre Comportamento do Consumidor. Trabalho apresentado no IV Pró-Pesq PP - Encontro de Pesquisadores em Publicidade e Propaganda. De 23 a 24/05/2013. CRP/ECA/USP.

Sá, R. N. (2011). As influências da fenomenologia e do existencialismo na psicologia. In: JacóVilela, A. M., Ferreira, A. A. L. \& Portugal, F. T. Rio de Janeiro: Nau Editora.

Sadek, M. T. (1989). Da Revolução. Resenha. São Paulo: Lua nova, No. 16, março.

Samara, B. S. \& Morch, M. A. (2005). Comportamento do Consumidor. Conceitos e Casos. São Paulo: Pearson - Prentice Hall.

Santos, T., Lima, M. V. V., Brunetta, D. F., Fabris, C. \& Seleme, A. (2009). O Desenvolvimento do Marketing: Uma perspectiva histórica. Revista de Gestão USP, São Paulo, V. 16, No. 1, p. 89-102, janeiro-março.

Sawaya, A.L \& Filgueiras, A. Abra a felicidade? Implicações para o vício alimentar. Estudos Avançados, 27 (78), pp 53-70, 2013

Schmitt, B. H. Marketing Experimental. Tradução: Sara Gedanke. São Paulo: Nobel, 2002.

Schultz, D. P. \& Schultz, S. E. (2005). História da Psicologia Moderna. São Paulo: Pioneira Thomson Learning.

Shaw, E. H. \& Jones, D.G. B. (2005). A history of schools of marketing thought. Marketing Theory Articles. Volume 5 (3): 239-281. Retirado do World Wide Web <http//: www.sagepublications.com> acessado em 3 de abril de 2013.

Simões, R. (1976). Marketing Básico. São Paulo: Saraiva.

Sheth, J.N.; Gardner, D. M \& Garrett, D. E. (1988). Marketing theory: evolution and evaluation. New York: John Wiley \& Sons.

Solomon, M. (2002). O comportamento do Consumidor: Comprando, Possuindo e Sendo. Porto Alegre: Bookman. In: Samara, B. S. \& Morch, M. A. (2005). Comportamento do Consumidor. Conceitos e Casos. São Paulo: Pearson - Prentice Hall.

Tenório, F.G. (2004). Responsabilidade social empresarial: teoria e prática. Org. Fernando Guilherme Tenório; colaboradores Fabiano Christian Pucci do Nascimento (et al.). Rio de Janeiro: Ed. FGV.

Tfouni, L. V., Aoki, F. C. O. S \& Souza, A. C. (2010). Projeções da linguagem midiática na educação. E-escrita. Revista do Curso de Letras da UNIABEU: Nilópolis, v. I, Número 3, Set-Dez. 
Watson, J. B. (1913/2008). Clássico traduzido: A psicologia como o behaviorista a vê. Artigo originalmente publicado em Psychological Review, 20(2), 158-177. Artigo em domínio público. (Gerab, F. K., Moreira, L. E. V., Castelli, M. Z. , Ambra, P. E. , Gehm, T. P. \& Neto, M. B. C. Temas em Psicologia, Vol. 16, No. 2, 289-301.

Wiendieck, G. (1997). Advertising Psychology. In: Bringmann, W. G., Lück, H. E., Miller, R. \& Early, C. E. A Pictorial History of Psychology. Canada: Quintessence Books.

Zanotta, E. B. \& Zanotta, R. S. (2001). Evolução do Marketing. In: Las Casas, A. L. (coord.). Novos Rumos do Marketing. São Paulo: Atlas.

(2005, março). Luigi Giussani: datas históricas. Revista Passos: Revista Internacional de Comunhão e Libertação, ano XX, no. 59, 64 páginas.

Sumário de Conclusões - Pesquisa AKATU 2012. Rumo à Sociedade do Bem-Estar: Assimilação e Perspectivas do Consumo Consciente no Brasil - Percepção da Responsabilidade Social Empresarial pelo Consumidor Brasileiro. Recuperado em 4 de abril de 2014, de http://www.akatu.org.br/Content/Akatu/Arquivos/file/Relatório akatu2013.pdf 


\section{8 - ANEXO - RELAÇÃO DE OBRAS DE LUIGI GIUSSANI}

Entre suas principais obras de Giussani, traduzidas em várias línguas estão : os três volumes do "Percorso" série: Il Senso Religioso (1997) [O Senso Religioso, 1997], All'origine della pretesa cristiana (2001) [Na origem da pretensão cristã, 1998] e Perché la Chiesa (2003) [Por que a Igreja, 2001] - Il rischio educativo(2005) [O Risco da Educação, 2001] - ? Si può vivere così [? É possível viver assim, 2008] (2007) - Il vero è Cammino al un'esperienza (2006) [O caminho para a verdade é uma experiência, 2006] - L'avvenimento cristiano. Uomo Chiesa Mondo (1993), seu primeiro livro publicado pela Rizzoli. - L'opera del Movimento. La Fraternità di comunione e Libertação(2002) [O trabalho do movimento. A Fraternidade de Comunhão e Libertação, 2005]-L'io, il potere, le opere (2000) - L'autocoscienza del cosmo (2000)-? Che cos'è l'uomo perché te ne Curi (2000) [Os Salmos , 2004] - L'attrattiva Gesù (1999) - L'uomo e il suo Destino (1999) Generare Tracce nella storia del mondo. Nuove di Tracce esperienza cristiana (1998), escrito em conjunto com Stefano Alberto e Javier Prades [Traços gerando na História do Mundo. Traços nova experiência cristã, 2010] - «Tu» (o dell'amicizia) (1997) - Alla ricerca del volto umano (1995) - Il senso di Dio e l'uomo moderno (1994) - Le mie letture (2008) Teologia protestante americana.Profilo Storico (2003) - familiarità con Cristo. Meditazioni sull'anno litúrgico (2008) - Sul senso Religioso (2009), coleção de escritos de Giovanni B. Montini e Luigi Giussani - Os volumes Equipe: Dall'utopia alla Presenza (1975-1978), Certi di alcune grandi cose (1978 -1981), Uomini senza patria (1982-1983), Qui e ora (19841985), L'io rinasce in un incontro (1986-1987), CIO che di più abbiamo caro (1988-1989) ${ }^{85}$.

\footnotetext{
${ }^{85}$ Retirado do World Wide Web <http://english.clonline.org/whatiscl/default.asp?id=443> em 10 de março de 2013.
} 